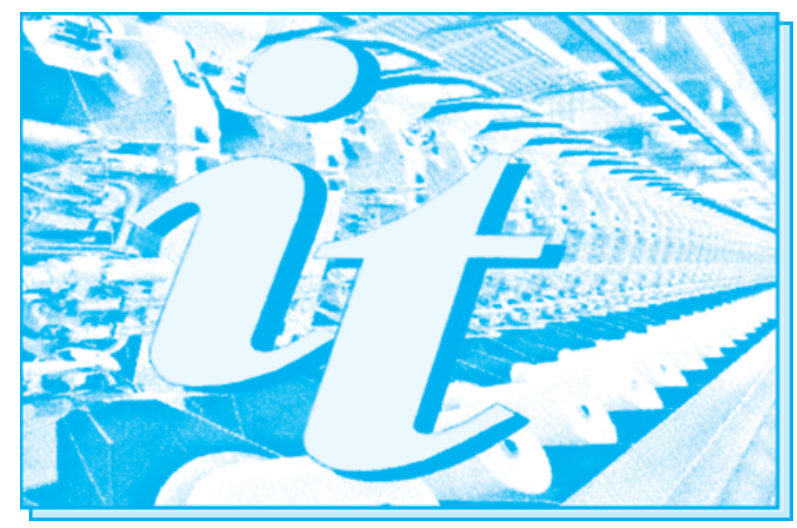

Revistă cotată ISI si inclusă în Master Journal List a Institutului pentru Știința Informării din Philadelphia - S.U.A., începând cu vol. 58, nr. $1 / 2007 /$

ISI rated magazine, included in the ISI Master Journal List of the Institute of Science Information, Philadelphia, USA, starting with vol. 58, no. 1/2007

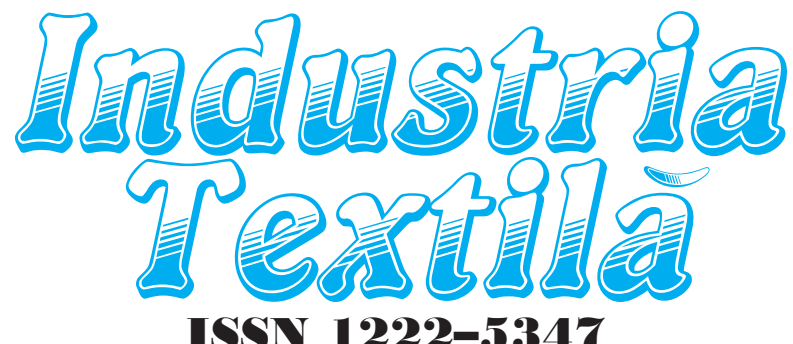

ISSN 1222-5347

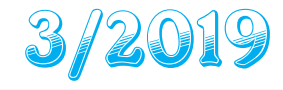

Editată în 6 nr./an, indexată si recenzată în:

Edited in 6 issues per year, indexed and abstracted in:

Science Citation Index Expanded (SciSearch $\left.{ }^{\circledR}\right)$, Materials Science Citation Index ${ }^{\circledR}$, Journal Citation Reports/Science Edition, World Textile

Abstracts, Chemical Abstracts, VINITI, Scopus, Toga FIZ technik ProQuest Central, Crossref DOI

Editată cu sprijinul Ministerului Cercetării și Inovării

\section{DELEGIUL}

\section{Dr. ing. CARMEN GHITULEASA}

CS I- DIRECTOR GENERAL

Institutul Naţional de Cercetare-Dezvoltare pentru Textile şi Pielărie - Bucureşti

\section{Dr. ing. EMILIA VISILEANU} CS I - EDITOR ŞEF

Institutul Național de Cercetare-Dezvoltare pentru Textile şi Pielărie - Bucureşti

Conf. univ. dr. ing. MARIANA URSACHE DECAN

Facultatea de Textile-Pielărie

şi Management Industrial, Universitatea

Tehnică „Ghe. Asachi“ - laşi

\section{Prof. dr. GELU ONOSE}

CSI

Universitatea de Medicină şi Farmacie

„Carol Davila“ - Bucureşti

Prof. dr. ing. ERHAN ÖNER

Marmara University - Turcia

Prof. dr. S. MUGE YUKSELOGLU

Marmara University - Turcia

Prof. univ. dr. DOINA I. POPESCU

Academia de Studii Economice - Bucureşti

Prof. univ. dr. ing. CARMEN LOGHIN PRO-RECTOR

Universitatea Tehnică "Ghe. Asachi“ - laşi

Prof. univ. dr. MARGARETA STELEA FLORESCU

Academia de Studii Economice - Bucureşti

Prof. dr. ing. LUIS ALMEIDA

University of Minho - Portugal

Prof. $d r$. LUCIAN CONSTANTIN HANGANU

Universitatea Tehnică „Ghe. Asachi“ - laşi

Dr. AMINODDIN HAJI

PhD, MSc, BSc, Textile Chemistry and Fiber Science

ASSISTANT PROFESSOR

Textile Engineering Department Yazd University

Yazd, Iran

Dr. ADNAN MAZARI

ASSISTANT PROFESSOR

Department of Textile Clothing

Faculty of Textile Engineering

Technical University of Liberec Czech Republic

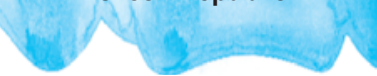

RALUCA MARIA AILENI, RAZVAN ION RADULESCU, LAURA CHIRIAC, LILIOARA SURDU

Evaluarea ciclului de viață al textilelor electroconductoare functionalizate prin tehnologii avansate (plasmă) și depunere de micro/nanoparticule metalice

MOHSIN MUHAMMAD, NAI-WEN LI, AUNJAM SOHAIL MUHAMMAD,

MAJEED KASHIF MUHAMMAD

Investigarea diferiților factori care influențează coeficientul de frecare al firelor folosind metoda Taguchi

MUSA KILIC, GONCA BALCI KILIC, EFLATUN TIRYAKI, H. KÜBRA KAYNAK, MURAT DEMIR

Efectele utilizării deșeurilor de bumbac asupra proprietăților firelor filate cu rotor $\mathrm{OE}$ și ale materialelor tricotate

RALUCA MARIA AILENI, LAURA CHIRIAC, SILVIA ALBICI, ADRIANA SUBTIRICA LAURENTIU CRISTIAN DINCA

Aspecte ale sustenabilității efectului hidrofob obținut în plasmă pentru țesăturile din bumbac

YAO LU, SI CHEN, NAN-NAN LI, BIN HU, YOU-KAI CHEN, SHUANG-LIN ZHOU Prepararea plasei PDO și studio privind parametrii de fabricare

229-235

LAURA CHIRILA, CARMEN GAIDAU, MALVINA STROE, MIHAELA BAIBARAC, MARIA STANCA, DENISA MARIA RĂDULESCU, DIANA ELENA RĂDULESCU, COSMIN-ANDREI ALEXE

Proprietățile materialelor textile și din piele tratate cu noi nanocompozite hibride pe bază de $\mathrm{SiO}_{2} / \mathrm{TiO}_{2} /$ poli(2,2'-bitiofen)

MIHAI-ALEXANDRU PĂUN, ADRIAN FRUNZĂ, ELENA-LUMINIȚA STĂNCIULESCU, TIBERIU-CIPRIAN MUNTEANU, IOAN CRISTESCU, SABINA GRAMA, ALEXANDRA ENE, CARMEN MIHAI, ALEXANDRU CHIOTOROIU

Utilizarea plaselor din polipropilenă acoperite cu collagen pentru chirurgia reconstructivă nazală

ONUR UGUR CINKO, BEHCET BECERIR

Dependenta formulelor de diferentă a culorii asupra modificărilor coordonatelor de culoare în spatiul de culoare CIELAB

RIZA ATAV, A. ÖZGÜR AĞIRGAN, DERMAN VATANSEVER BAYRAMOL, AYLIN YILDIZ Complecși de incluziune ai $\beta$-ciclodextrinei cu $\mathrm{Fe}_{3} \mathrm{O}_{4} @ \mathrm{HA} @ \mathrm{Ag}$ Partea I: Preparare si caracterizare

SÜMEYYE ÜSTÜNTAĞ, HÜSEYIN GAZI TÜRKSOY

Optimizarea parametrilor de acoperire pentru permeabilitatea la aer a țesăturilor denim prin metoda Taguchi

JOSÉ-VICENTE TOMÁS-MIQUEL, MANUEL EXPÓSITO-LANGA,

GABRIEL BRĂTUCU, OANA BĂRBULESCU

Studiu privind efectele rețelelor interorganizaționale asupra inovării din industria textilă. Cazul unui cluster din Valencia, Spania

TEODOR HADA, NICOLETA BĂRBUTĂAISSU, TEODORA MARIA AVRAM

Evaluarea performantei financiare a firmelor din industria textilă din România

272-277

GAMZE SÜPÜREN MENGÜÇ, EYLEN SEMA DALBAŞI, ARIF TANER ÖZGÜNEY, NILGÜN ÖZDIL

Studiu comparativ al tușeului țesăturilor din bambus și bumbac

278-284

MANOJ KUMAR PARAS, ANTONELA CURTEZA, RUDRAJEET PAL,

LICHUAN WANG, YAN CHEN

Un studiu de caz din România privind valorificarea îmbrăcămintei și a accesoriilor 285-290

YUSUF KAYA, GIZEM GÜNAYDIN KARAKAN, EMILIA VISILEANU

Impactul mișcărilor de schimb valutar asupra sectorului textil din Turcia

291-296

Recunoscută în România, în domeniul Științelor inginerești, de către

Consiliul Național al Cercetării Științifice din Învățământul Superior (C.N.C.S.I.S.), în grupa A

Aknowledged in Romania, in the engineering sciences domain, by the National Council of the Scientific Research from the Higher Education (CNCSIS), in group $A$ 


\section{Contents}

RALUCA MARIA AILENI,

RAZVAN ION RADULESCU,

LAURA CHIRIAC, LILIOARA SURDU

MOHSIN MUHAMMAD, NAI-WEN LI, AUNJAM SOHAIL MUHAMMAD,

AUNJAM KASHIF MUHAMMAD

MUSA KILIC, GONCA BALCI KILIC EFLATUN TIRYAKI, H. KÜBRA KAYNAK, MURAT DEMIR

RALUCA MARIA AILENI, LAURA CHIRIAC SILVIA ALBICI, ADRIANA SUBTIRICA LAURENTIU CRISTIAN DINCA

YAO LU, SI CHEN, NAN-NAN LI, BIN HU, YOU-KAI CHEN, SHUANG-LIN ZHOU

LAURA CHIRILA, CARMEN GAIDAU, MALVINA STROE, MIHAELA BAIBARAC, MARIA STANCA DENISA MARIA RÄDULESCU, DIANA ELENA RADUASU, RADULESU, DIANAELE

MIHAI-ALEXANDRU PĂUN, ADRIAN FRUNZĂ, ELENA-LUMINITA STĂNCIULESCU, TIBERIU-CIPRIAN MUNTEANU, IOAN CRISTESCU, SABINA GRAMA IOAN CRISTESCU, SABINA GRAMA, ALEXANDRA ENE, CARMEN MIHAI, ALEXANDRU CHIOTOROIU

ONUR UGUR CINKO, BEHCET BECERIR

RIZA ATAV, A. ÖZGÜR AĞIRGAN

DERMAN VATANSEVER BAYRAMOL,

AYLIN YILDIZ

SÜMEYYE ÜSTÜNTAĞ, HÜSEYIN GAZI TÜRKSOY

JOSÉ-VICENTE TOMÁS-MIQUEL,

MANUEL EXPÓSITO-LANGA,

GABRIEL BRĂTUCU, OANA BĂRBULESCU

TEODOR HADA, NICOLETA BĂRBUTĬ-MIŞU, TEODORA MARIA AVRAM

GAMZE SÜPÜREN MENGÜC, EYLEN SEMA DALBAŞI, ARIF TANER ÖZGUUNNEY, NILGÜN ÖZDiL

MANOJ KUMAR PARAS, ANTONELA CURTEZA, RUDRAJEET PAL, LICHUAN WANG, YAN CHEN

YUSUF KAYA, GIZEM GÜNAYDIN KARAKAN EMILIA VISILEANU
Life cycle assessment of the electroconductive textiles functionalized by advanced technologies (plasma) and metallic micro/nanoparticles deposition

Investigation of various factors affecting the coefficient of friction of yarn by using Taguchi method

Effects of waste cotton usage on properties of OE-rotor yarns and knitted fabrics

216

Aspects of the hydrophobic effect sustainability obtained in plasma for cotton fabrics

Preparation of PDO mesh and research on its fabrication parameters

229

Properties of textile and leather materials treated with new hybrid $\mathrm{SiO}_{2} / \mathrm{TiO}_{2} / \mathrm{poly}\left(2,2^{\prime}\right.$-bithiophene $)$ nanocomposites

The use of collagen-coated polypropylene meshes for nasal reconstructive surgery

Dependence of colour difference formulae on regular changes of colour coordinates in CIELAB colour space

Inclusion complexes of $\mathrm{\square -cyclodextrine} \mathrm{with} \mathrm{Fe}_{3} \mathrm{O}_{4} @ \mathrm{HA} @ \mathrm{Ag}$ Part I: Preparation and characterization

Optimization of coating parameters for air permeability of denim fabrics through Taguchi method

Unravelling the effects of interorganizational networks on innovation in the textile industry. The case of the Valencian cluster in Spain

Evaluating firms' financial performance in textile industry of Romania 272

A comparative study on handle properties of bamboo and cotton fabrics 278

A Romanian case study of clothes and accessories upcycling 285

The impact of foreign exchange movements on Turkish textile sector 291

The INDUSTRIA TEXTILA magazine, edited by INCDTP BUCHAREST, implements and respects Regulation 2016/679/EU on the protection of individuals with regard to the processing of personal data and on the free movement of such data ("RGPD"). For information, please visit the Personal Data Processing Protection Policy link: E-mail DPO rpd@certex.ro

Scientific reviewers for the papers published in this number:

Prof. Ciocoiu Mihai, “Gh. Asachi” Technical University, lasi, Romania

Dr. Sajjad Ahmad Baig, National Textile University Faisalabad, Pakistan

Prof. Pablo Diaz Garcia, Polytechnic University of Valencia, Spain

Dr. Geetika Varshneya, Development Management Institute, Bihar, India

Dr. Concepció Casas, A3 Leather Innovation Center, Spain

Dr. Bojana Voncina, University of Maribor, Slovenia

Assoc. Prof. Dr. Ercan Şenyiğit, Erciyes University, Engineering Faculty, Industrial Engineering Department, Kayseri, Turky

Prof. Josep Capo-Vicedo, Universitat Politècnica de València, Spain Assoc. Prof. Dr. Hatice Harmankaya, Selçuk University, Department of Fashion Design, Selcuk, Turky

\begin{tabular}{|c|}
\hline EDITORIAL STAFF \\
Editor-in-chief: Dr. eng. Emilia Visileanu \\
Graphic designer: Florin Prisecaru \\
e-mail: industriatextila@ certex.ro
\end{tabular}

Journal edited in colaboration with Editura AGIR, 118 Calea Victoriei, sector 1, Bucharest, tel./fax: 021-316.89.92; 021-316.89.93; e-mail: editura@agir.ro, www.edituraagir.ro 


\title{
Life cycle assessment of the electroconductive textiles functionalized by advanced technologies (plasma) and metallic micro/nanoparticles deposition
}

\author{
DOI: $10.35530 / I T .070 .03 .1476$
}

RALUCA MARIA AILENI

RAZVAN ION RADULESCU

LAURA CHIRIAC

LILIOARA SURDU

\section{REZUMAT - ABSTRACT}

Evaluarea ciclului de viață al textilelor electroconductoare funcționalizate prin tehnologii avansate (plasmă) și depunere de micro/nanoparticule metalice

Această lucrare prezintă mai multe aspecte privind evaluarea ciclului de viață al textilelor electroconductoare funcționalizate prin tehnologia avansată cu plasmă RF pe bază de argon și oxigen și depunerea de micro/nanoparticulele metalice. Pentru a obține textile cu proprietăți electroconductoare, planul nostru preliminar a constat în funcționalizarea textilelor prin utilizarea tehnologiei cu plasmă RF pe bază de argon și oxigen și a proceselor de depunere a micro/nanoparticulelor, cum ar fi fulardarea, imprimarea directă și depunerea de pelicule subțiri. S-a analizat inventarul ciclului de viață (LCI) și s-a elaborat studiul pentru evaluarea ciclului de viață (LCA) folosind software-ul SimaPro și Eco-indicator 99. Pentru a obține $\mathrm{LCl}$, s-au utilizat datele tehnice de intrare și ieșire din procesele cu plasmă și software-ul SimaPro pentru generarea LCI și LCA. Datele de intrare despre materia primă, energia, substanțele chimice au fost colectate prin măsurători directe pe echipamente, manuale de utilizare și specificațiile echipamentelor (cărți tehnice) și procese. Datele de ieșire au fost obținute utilizând software-ul SimaPro conectat la baze de date de pe internet. Obiectivul studiului a fost studierea evaluării ciclului de viață al textilelor electroconductoare funcționalizate prin tehnologia cu plasmă RF în comparație cu tratamentele de funcționalizare clasice.

Cuvinte-cheie: tehnologia cu plasmă, microundă, microparticule, electroconductor, LCA, textile

Life cycle assessment of the electroconductive textiles functionalized by advanced technologies (plasma) and metallic micro/nanoparticles deposition

This paper presents aspects concerning the life cycle assessment of the electroconductive textile functionalized by advanced RF plasma technology based on argon and oxygen gases and deposition of the metallic micro/nanoparticles. In order to obtain the textiles with electroconductive properties, the preliminary plan consisted functionalization of the textiles by using RF plasma technology based on argon and oxygen gases and processes for micro/nanoparticles deposition such as foulard, direct printing, and thin film position. It was analyzed the life-cycle inventory (LCI) and was provided the study for life-cycle assessment (LCA) using SimaPro software and Eco-indicator 99. In order to obtain the LCl, we used to input and output technical data, from the plasma process, and the SimaPro software for generating the LCI and LCA. The input data about raw material, energy, chemical substances, have been collected by direct measurements on machinery, device log, and specifications of the equipment (technical books) and processes. The output data was obtained using SimaPro software connected to internet-specific databases. The purpose of our research has been to study the life cycle assessment of the electroconductive textiles functionalized by RF plasma technology in comparison with classical functionalization treatments.

Keywords: plasma technology, microwave, microparticles, electroconductive, LCA, textile

\section{INTRODUCTION}

The recent studies concerning the harmful effect of chemicals for health, land, water, air or GES (greenhouse gases) disposal in the atmosphere, conclude that is a direct influence between industrial revolu tions and occurrence of the diseases such as cancers and climatic changes. According to Global Climate Report, NOAA, 2018, in 2018, 11 months at global land and ocean level, the temperature departures from average ranked among the five warmest for their respective months. Also, the years 2015-2017 each had a global temperature departure from average that was more than $1.0^{\circ} \mathrm{C}$ above the 1880-1900 average, a period that represents the pre-industrial conditions [1]. The greenhouse gases such as carbon dioxide, methane, nitrous oxide, and fluorinated gases, when are emitted become trapped in the Earth 'atmosphere, and therefore, the heat becomes trapped inside greenhouse [2].

However, from the end of the 1700s, the net global effect of human activities has generated a continual increase in greenhouse gas concentrations and global warming of the past 50 years [3-5]. The greenhouse gases affect climate, including surface air and ocean temperatures, precipitation, and sea levels. Besides, human health, agriculture, water resources, forests, wildlife, and coastal areas are all vulnerable to climate change [5]. The greenhouse gases remain in the atmosphere for tens to hundreds of years after being released [4-5].

Also, emissions in the atmosphere decrease the ozone layer, and this promotes increased UV-B level that has adverse effects on human health because it 
generates immune suppression, skin cancers, and cataract [6].

Life Cycle Assessment (LCA) has the objective to study the impact of the products to the nature, health, resources, without geographic borders, in terms of the raw material and energy supplies [6-8]. The first step in obtaining the LCA is to generate the LCl (Life Cycle Inventory) based on input and output data about the processes.

Besides, LCl involves data collection about water, energy, and chemical substances necessary to obtain textiles for antistatic effect. For the evaluation of the life cycle for textiles, products finished using traditional and advanced processes and technologies we consider the following inputs and outputs (figure 1):

- inputs: energy, water, chemical substances (acquisition $\rightarrow$ production $\rightarrow$ usage)

- outputs: waste, wastewater, emissions (recycling | reuse)

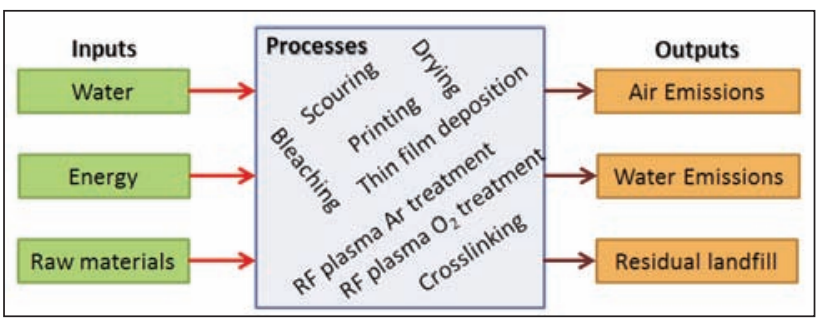

Fig. 1. Simplified map LCl: input-output data and processes

\section{EXPERIMENTAL PART}

In order to evaluate the environmental impact of the electroconductive fabrics, were designed the technological flows based on the advanced processes such RF plasma functionalization using oxygen gas, respective argon gas and based on classical processes for copper microparticles deposition using direct printing, film coating and foulard methods. The input data were obtained by life-cycle inventory ( $\mathrm{LCl}$ ) for these processes and inventory of the used resources, taking into account the constraints imposed by the nature of the processes and equipment used.

In order to obtain LCA for fabrics with conductive and antistatic effect, has been designing technological flows based on advanced plasma processes (advanced functionalization by RF plasma generated at low pressure in argon, respectively in the oxygen) and based on classical processes for the copper deposition by foulard method, thin film deposition and direct printing. Requested data for LCA were obtained following the completion of the life cycle inventory ( $\mathrm{LCl}$ ) for these processes and the calculation of the resources used, taking into account the constraints imposed by the nature of the processes and equipment used.

For the conduct of the LCA study by comparing the effect of RF plasma argon with standard treatment, respective by comparing RF plasma oxygen with standard treatment, we have selected several technological flows (TF):
1. Scouring $\rightarrow$ Bleaching $\rightarrow$ Drying $\rightarrow$ RF Plasma (Argon) $\rightarrow$ treatment by foulard method (Arristan EPD + copper microparticles) $\rightarrow$ Thermal conden sation

2. Scouring $\rightarrow$ Bleaching $\rightarrow$ Drying $\rightarrow$ RF Plasma (oxygen) $\rightarrow$ thin film deposition (Tubicoat A $41+$ Tubivis DL 650 + copper microparticles) $\rightarrow$ Thermal condensation

3. Scouring $\rightarrow$ Bleaching $\rightarrow$ Drying $\rightarrow$ RF Plasma (Argon) $\rightarrow$ Printing (Tubifast AS $30+$ Tubivis DL 650 + Tubifix ML 55 + copper microparticles) $\rightarrow$ Thermal condensation

The input data for LCl and LCA, are presented in tables 1-3 for standard technologies for copper microparticles deposition by printing, foulard method, and thin film deposition. Also, data for LCl and LCA concerning RF plasma oxygen and RF plasma argon are presented tables 4-5.

\begin{tabular}{|c|c|c|}
\hline & & Table 1 \\
\hline \multicolumn{3}{|c|}{ INPUT DATA - PRINTING PROCESS } \\
\hline Data about the industrial process & U.M. & Value \\
\hline \multicolumn{3}{|l|}{ 1. Data about fabric consumption } \\
\hline Fibrous composition & \multicolumn{2}{|c|}{$100 \%$ cotton } \\
\hline \multirow{2}{*}{ Mass } & $\mathrm{g} / \mathrm{m}^{2}$ & 401 \\
\hline & $\mathrm{g} / \mathrm{ml}$ & 602 \\
\hline $\begin{array}{l}\text { Mass (the fabric used in } \\
\text { the industrial process) }\end{array}$ & $\mathrm{kg}$ & 100 \\
\hline \multicolumn{3}{|l|}{ 2. Data about the printing process } \\
\hline Printing device & - & - \\
\hline \multicolumn{3}{|c|}{ 2.1 Data about chemicals substances consumption } \\
\hline Tubifast AS 30 & $\mathrm{~kg}$ & 0.060 \\
\hline Tubivis DL 650 & $\mathrm{~kg}$ & 0.003 \\
\hline Tubifix ML 55 & $\mathrm{~kg}$ & 0.0015 \\
\hline Copper microparticles & $\mathrm{kg}$ & 0.06 \\
\hline \multicolumn{3}{|c|}{ 3. Data about printing equipment consumptions } \\
\hline 3.1 Water for treatment solution & $\mathrm{L}$ & 0.176 \\
\hline 3.2 Wastewater & $\mathrm{L}$ & 0 \\
\hline 3.3 Process duration & $\min$ & 3 \\
\hline
\end{tabular}

LCA has been obtained using the program SimaPro7 and the method ECO-Indicator 99 (E)/Europe El 99 E/E. The method ECO-Indicator 99 provides for the quantification of the environmental impact processes using categories of impact such as: carcinogenic substances, organic and inorganic chemicals harmful by breathing, climatic changes due to the greenhouse effect gases, radiation, ozone layer level, ecotoxicity, acidification/Eutrophication, land use, minerals and fossil fuels consumed for production of electricity [9-10].

For LCA, using SimaPro7 [11-12] can be used in the following methods:

- Normalization method;

- Weighting method;

- Specification method;

- Damage assessment method;

- Characterization method. 


\begin{tabular}{|c|c|c|}
\hline \multicolumn{3}{|c|}{ THIN FILM DEPOSITION PROCESS } \\
\hline Data about the industrial process & U.M. & Value \\
\hline \multicolumn{3}{|l|}{ 1. Data about fabric consumption } \\
\hline Fibrous composition & \multicolumn{2}{|c|}{$100 \%$ cotton } \\
\hline \multirow{2}{*}{ Mass } & $\mathrm{g} / \mathrm{m}^{2}$ & 401 \\
\hline & $\mathrm{g} / \mathrm{ml}$ & 602 \\
\hline $\begin{array}{l}\text { Mass (the fabric used in the } \\
\text { industrial process) }\end{array}$ & $\mathrm{kg}$ & 100 \\
\hline \multicolumn{3}{|c|}{ 2. Data about the thin film deposition process } \\
\hline Thin film deposition device & - & - \\
\hline \multicolumn{3}{|c|}{ 2.1 Data about chemicals substances consumption } \\
\hline Tubicoat A41 & $\mathrm{kg}$ & 0.12 \\
\hline Tubivis DL 650 & $\mathrm{~kg}$ & 0.0027 \\
\hline Copper microparticles & $\mathrm{kg}$ & 0.06 \\
\hline \multicolumn{3}{|c|}{$\begin{array}{l}\text { 3. Data about thin film deposition equipment } \\
\text { consumptions }\end{array}$} \\
\hline 3.1 Water for treatment solution & L & 0.117 \\
\hline 3.2 Wastewater & $\mathrm{L}$ & 0 \\
\hline 3.3 Process duration & $\min$ & 3 \\
\hline
\end{tabular}

\begin{tabular}{|l|c|c|}
\hline \multicolumn{3}{|c|}{ RF PLASMA OXYGEN PROCESS } \\
\hline \multicolumn{1}{|c|}{ Data about the industrial process } & U.M. & Value \\
\hline 1. Data about fabric consumption \\
\hline Fibrous composition & $100 \%$ cotton \\
\hline \multirow{2}{*}{ Mass } & $\mathrm{g} / \mathrm{m}^{2}$ & 401 \\
\cline { 2 - 3 } & $\mathrm{g} / \mathrm{ml}$ & 602 \\
\hline $\begin{array}{l}\text { Mass (the fabric used in the } \\
\text { industrial process) }\end{array}$ & $\mathrm{kg}$ & 100 \\
\hline 2. Data about the RF plasma oxygen process \\
\hline RF plasma device: - Power & $\mathrm{kWh}$ & 4.16 \\
\cline { 2 - 3 } & $\mathrm{min}$ & 5 \\
\hline 2.1 Data about chemicals substances consumption \\
\hline Oxygen gas & $\mathrm{g}$ & 67 \\
\hline 3. Data about foulard equipment consumptions \\
\hline 3.1 Water for treatment solution & $\mathrm{L}$ & 0 \\
\hline 3.2 Energy & $\mathrm{kW}$ & 21 \\
\hline 3.3 Wastewater & $\mathrm{L}$ & 0 \\
\hline 3.4 Process duration & min & 5 \\
\hline
\end{tabular}

\begin{tabular}{|c|c|c|}
\hline \multicolumn{3}{|c|}{ FOULARD METHOD PROCESS } \\
\hline Data about the industrial process & U.M. & Value \\
\hline \multicolumn{3}{|l|}{ 1. Data about fabric consumption } \\
\hline Fibrous composition & \multicolumn{2}{|c|}{$100 \%$ cotton } \\
\hline \multirow{2}{*}{ Mass } & $\mathrm{g} / \mathrm{m}^{2}$ & 401 \\
\hline & $\mathrm{g} / \mathrm{ml}$ & 602 \\
\hline $\begin{array}{l}\text { Mass (the fabric used in the } \\
\text { industrial process) }\end{array}$ & $\mathrm{kg}$ & 100 \\
\hline \multicolumn{3}{|l|}{ 2. Data about foulard process } \\
\hline \multirow{2}{*}{$\begin{array}{r}\text { Thin film deposition device: }- \text { Power } \\
\text { - Time }\end{array}$} & kWh & 0.15 \\
\hline & $\min$ & 1 \\
\hline \multicolumn{3}{|c|}{ 2.1 Data about chemicals substances consumption } \\
\hline Arristan EPD + 20g/l Cu & $\mathrm{kg}$ & $\begin{array}{l}0.048+ \\
0.012\end{array}$ \\
\hline \multicolumn{3}{|c|}{ 3. Data about foulard equipment consumptions } \\
\hline 3.1 Water for treatment solution & $\mathrm{L}$ & 0.6 \\
\hline 3.2 Energy & $\mathrm{kW}$ & 0.0025 \\
\hline 3.3 Wastewater & $\mathrm{L}$ & 0 \\
\hline 3.4 Process duration & $\min$ & 1 \\
\hline
\end{tabular}

\begin{tabular}{|l|c|c|}
\hline \multicolumn{3}{|c|}{ RF PLASMA OXYGEN PROCESS } \\
\hline Data about the industrial process & U.M. & Value \\
\hline 1. Data about fabric consumption \\
\hline Fibrous composition & $100 \%$ cotton \\
\hline \multirow{3}{*}{ Mass } & $\mathrm{g} / \mathrm{m}^{2}$ & 401 \\
\cline { 2 - 3 } & $\mathrm{g} / \mathrm{ml}$ & 602 \\
\hline $\begin{array}{l}\text { Mass (the fabric used in the } \\
\text { industrial process) }\end{array}$ & $\mathrm{kg}$ & 100 \\
\hline 2. Data about the RF plasma oxygen process \\
\hline RF plasma device: & $\mathrm{kWh}$ & 4.16 \\
\cline { 2 - 3 } & $\mathrm{min}$ & 10 \\
\hline 2.1 Data about chemicals substances consumption \\
\hline Argon gas & $\mathrm{g}$ & 130 \\
\hline 3. Data about foulard equipment consumptions \\
\hline 3.1 Water for treatment solution & $\mathrm{L}$ & 0 \\
\hline 3.2 Energy & $\mathrm{kW}$ & 41 \\
\hline 3.3 Wastewater & $\mathrm{L}$ & 0 \\
\hline 3.4 Process duration & $\mathrm{min}$ & 10 \\
\hline
\end{tabular}

In figure 2 is presented the comparative LCA for cotton fabric functionalization by RF plasma, generated at low pressure in argon (Ar), and treated with a copper microparticles by foulard method (technological flow no. 1), vs. cotton fabric functionalization by RF plasma, generated at low pressure in oxygen (O2), and treated with copper microparticles by thin film deposition method (technological flow no. 2). In the case of comparative analysis of LCA for technologi-

cal flow no. 1, and technological flow no. 2 , it should be noted that in the case of technology no. 1, based on the RF plasma Ar and foulard method, the impact is $100 \%$ on all categories of impact (carcinogenic substances harmful, harmful chemicals through breathing, radiation, climate change, ozone depletion, ecotoxicity and consumption of fossil fuels necessary for producing electricity) and technology no. 2, based on RF plasma $\mathrm{O} 2$ and thin film deposition, the 


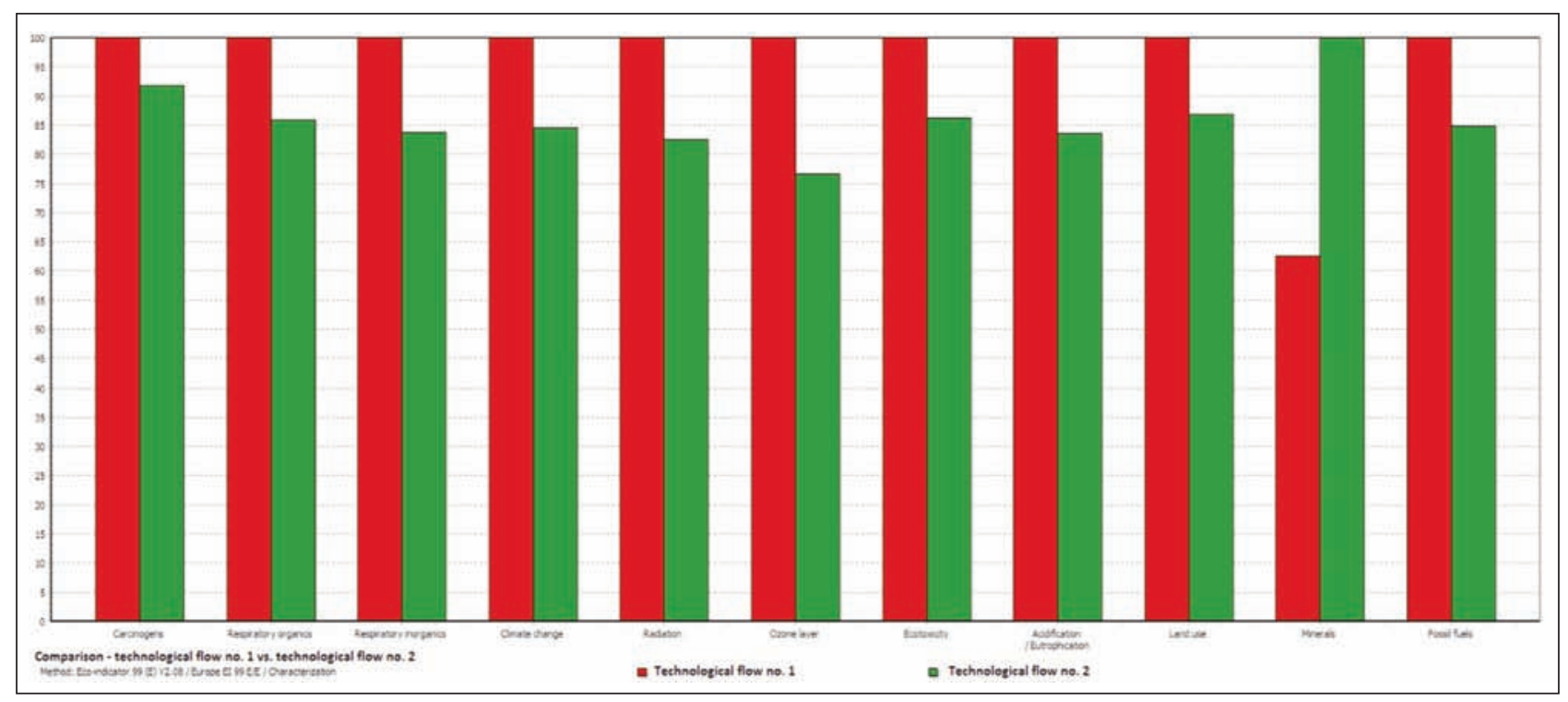

Fig. 2. Characterization method: comparative LCA - Technological Flow no.1 vs. technological flow no. 2

impact is less than $25 \%$ for the same categories of impact. The technological flow no. 2 has the value of impact $100 \%$ for the consumption of minerals, while for the technological flow no. 1 (TF no. 1) the impact on the consumption of minerals is $35 \%$ smaller.

In figure 3 is presented the histogram of the comparative LCA for cotton fabric functionalization by RF plasma Ar, and treated with copper microparticles by the foulard method (technological flow no. 1), vs. cotton fabric functionalization by RF plasma $\mathrm{Ar}$ and treated with copper microparticles using the printing method (technological flow no. 3). Analyzing LCA for TF no. 1 vs. TF no. 3 we mention that in the case of TF no. 1 , the impact is $100 \%$ on seven categories of impact (organic and inorganic chemicals with harmful effect through breathing, radiation, climatic changes due to $\mathrm{CO}_{2}$ emissions, ozone level, increase the acidity of the atmosphere because of greenhouse gases emissions and consumption of fossil fuels for the electricity production) and for the TF no. 3 the impact is less than $5 \%$ for the emitted radiation, respectively, with $15 \%$ less on ozone level minimizing. In the case of TF no. 1 the impact is less than $37 \%$ for the carcinogenic substances in comparison with the case TF no. 3, with $13 \%$ less than for ecotoxicity, and with $53 \%$ less than for minerals consumed.

In figure 4 is presented the histogram of the comparative LCA for cotton fabric functionalization by RF plasma $\mathrm{O} 2$ and treated with copper microparticles by the thin film deposition method (TF no. 2), vs. cotton fabric functionalization by RF plasma Ar and treated with copper microparticles printing method (TF no. 3). Within the framework of the histogram shown in figure 4, is highlighted the impact on the environment for the TF no. 2 in comparison with the TF no. 2.

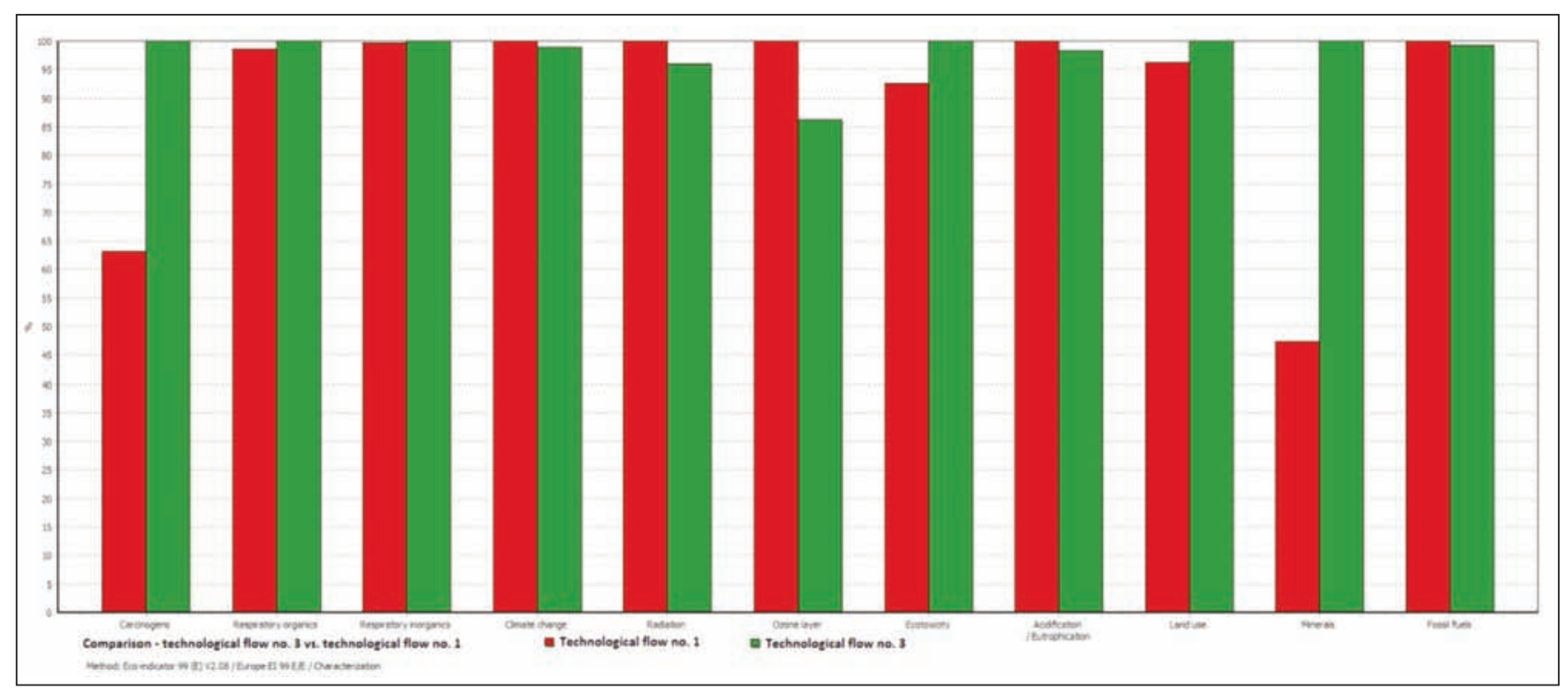

Fig. 3. Characterization method: comparative LCA - Technological Flow no.1 vs. technological flow no. 3 


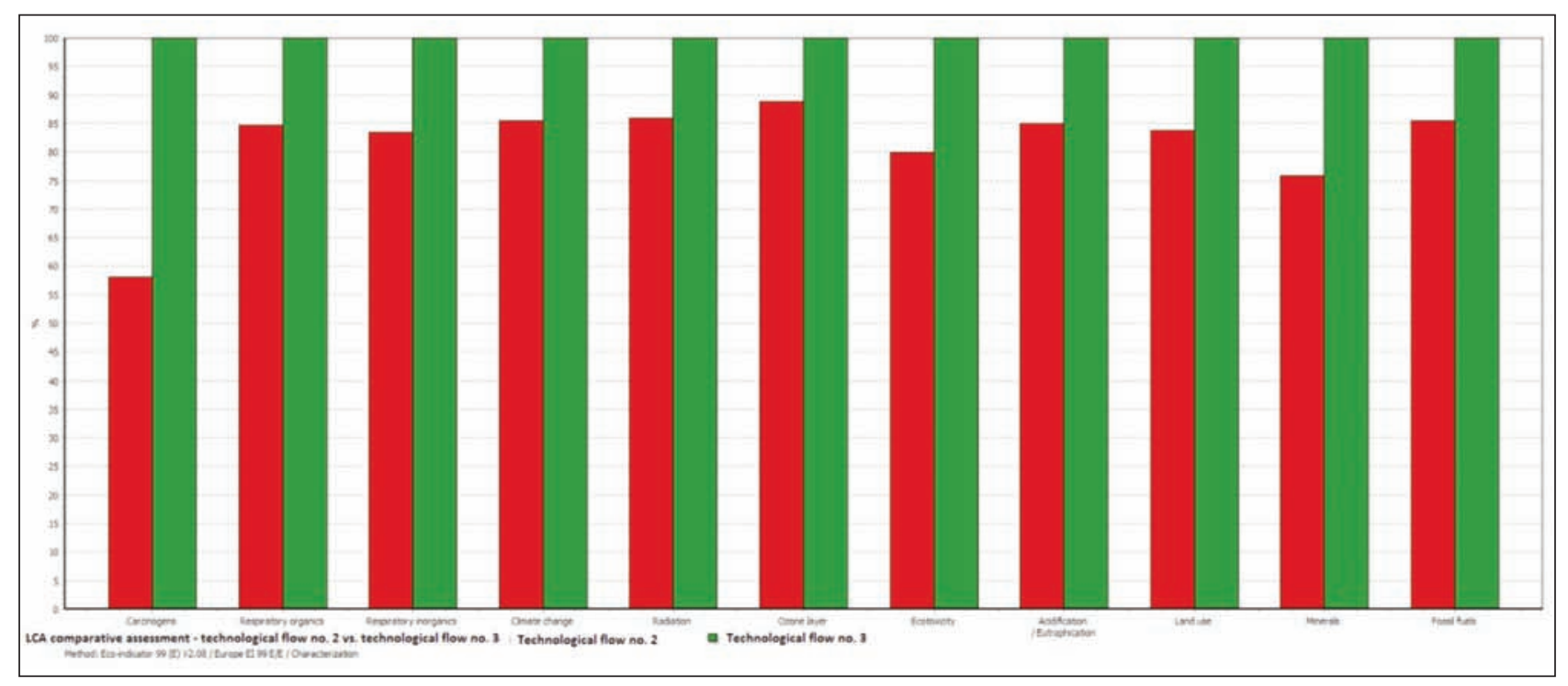

Fig. 4. The histogram of the comparative LCA - Technological flow no. 2 vs. technological flow no. 3

Therefore in comparison with the TF no. 3, TF no. 2 has an impact with more than $42 \%$ in carcinogenic substances and with $15-17 \%$ less than in organic and inorganic chemicals with harmful effect by breathing. TF no. 2 has an impact with approximately $15 \%$ less than TF no. 3 in the radiation and climate change, with $11 \%$ less on the reduction of the ozone layer, with $15 \%$ less in atmosphere acidification, with $20 \%$ less on ecotoxicity, with $16 \%$ less on the land use, with $25 \%$ less than on the minerals and with $15 \%$ less than in fossil fuels consumption for electricity production.

In the case of TF no. 2 (for thin film deposition), the energy consumption and the gas is $50 \%$ less than TF no. 1 and TF no. 3, because it uses the RF plasma $\mathrm{O} 2$ it is used just for $5 \mathrm{~min}$, and the water consumption $(0.117 \mathrm{I})$ is more than $80.05 \%$ compared to consumption that corresponds to TF no. 1 (0.6 I), i.e., with the $9.83 \%$ less than TF no. $3(0.176 \mathrm{I})$.

\section{CONCLUSIONS}

By analyzing the TF no. 3, we can mention that RF plasma Ar presents an electricity consumption by
$50 \%$ higher than the TF no. 2 and water consumption with $70.67 \%$ higher than TF no. 1. By analyzing the comparison between the $3 \mathrm{TFs}$, we conclude that the TF no. 1 has the most significant environmental impact due to the massive consumption of water, electricity, and gas. It can be concluded that the TF no. 2 has the lowest impact on the environment.

The classic processes based on the foulard method generates toxically vapor, heat, and wastewater, while RF plasma does not generate wastewater generate some harmful emission discharged in the atmosphere. In comparison with the traditional process, the technology RF plasma is more expensive as device and maintenance, and request high-qualified engineers, but is more efficient in cleaning and functionalization of the surface, being less time consuming and zero wastewater generators in comparison with classic surface activation.

\section{ACKNOWLEDGMENTS}

The research presented in this paper was prepared in the INCDTP laboratories. Funds support this work from $\mathrm{MCl}$, National Project "Optimizing the performance of the functional textile by advanced technologies", Contract PN 1823 0105.

\section{BIBLIOGRAPHY}

[1] Ncdc.noaa.gov. Global Climate Report - Annual 2018 | State of the Climate | National Centers for Environmental Information (NCEI). [online] Available at: https://www.ncdc.noaa.gov/sotc/global/201813 [Accessed 4 December 2018].

[2] RGS Energy. What are the ways greenhouse gases hurt the environment? - RGS Energy. [online] Available at: https://rgsenergy.com/solar-energy-myths-and-facts/what-are-the-ways-greenhouse-gases-hurt-the-environment/ [Accessed 17 November 2018].

[3] US EPA. Greenhouse Gases | US EPA. [online] Available at: https://www.epa.gov/report-environment/greenhousegases [Accessed 17 November 2018].

[4] Epa.gov., [online] Available at: https://www.epa.gov/sites/production/files/2016-08/documents/climate_indicators_ 2016.pdf [Accessed 7 December 2018]. 
[5] Nca2009.globalchange.gov, Global Climate Change | Global Climate Change Impacts in the United States 2009 Report Legacy site. [online] Available at: https://nca2009.globalchange.gov/global-climate-change/index.html [Accessed 7 December 2018].

[6] ILCD Handbook: Recommendations for Life Cycle Impact Assessment in the European context, European Union, ISBN $\square$ 978-92-79-17451-3, 2011.

[7] Corti, A. and Lombardi, L. End life types: Alternative final disposal processes compared by LCA, In: Energy, 2004, 29(12-15), pp. 2089-2108.

[8] Muthu, S.S. ed. Handbook of life cycle assessment (LCA) of textiles and clothing, Woodhead Publishing, 2015.

[9] Mary, A. C. Life Cycle Assessment Handbook, Wiley Publishing, USA, 2012.

[10] Suh, S. and Huppes, G. Methods for life cycle inventory of a product, In: Journal of Cleaner Production, 2005, 13(7), pp. 687-697.

[11] Walter, K., Birgit, G. Life Cycle Assessment (LCA), Wiley, 2014.

[12] SimaPro8. [online] Available at: http://www.simapro.co.uk/simapro8.html [Accessed 6 November 2018].

\section{Authors:}

RALUCA MARIA AILENI

RAZVAN ION RADULESCU

LAURA CHIRIAC

LILIOARA SURDU

National Research \& Development Institute for Textiles and Leather,

Lucretiu Patrascanu no.16, 030508 Bucharest, Romania

Corresponding author:

RALUCA MARIA AILENI

e-mail: raluca.aileni@certex.com

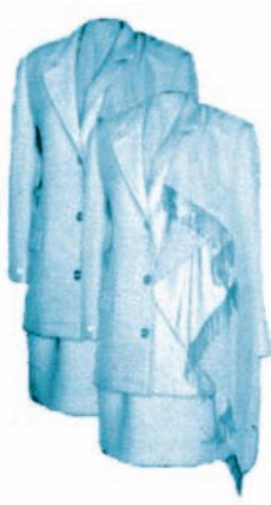




\title{
Investigation of various factors affecting the coefficient of friction of yarn by using Taguchi method
}

\author{
DOI: $10.35530 / 1 T .070 .03 .1555$
}

\section{REZUMAT - ABSTRACT}

\section{Investigarea diferiților factori care influențează coeficientul de frecare al firelor folosind metoda Taguchi}

Acest studiu are ca obiectiv analiza influenței tipului de bumbac, calității, tehnicii de filare, torsiunii, densității liniare și finisării firelor asupra coeficientului de frecare al firelor, utilizând metoda Taguchi. Pentru evaluarea nivelurilor și factorilor de răspuns, au fost realizate 72 de experimente utilizând proiectarea ortogonală $L_{36}$ de două ori pentru abordarea Taguchi. Rezultatele au arătat că firele formate din fibre fine, pieptănate, tratate cu parafină, filate cu rotor, cu torsiune optimă și densitate liniară scăzută au cel mai mic coeficient de frecare al firelor, îmbunătățind în cele din urmă procesele textile ulterioare și calitățile produsului.

Cuvinte-cheie: coeficient de frecare, proiectare ortogonală $L_{36}$, densitate liniară, abordare Taguchi, fir

\section{Investigation of various factors affecting the coefficient of friction of yarn by using Taguchi method}

This research aims to analyze certain effects of yarn characteristics such as: cotton type, yarn quality, yarn spinning technique, yarn twist and linear density and yarn finish on coefficient of friction of yarn by using Taguchi approach. For evaluation of levels and response factors, 72 experiments are performed by using $L_{36}$ orthogonal design twice for Taguchi approach. The results show that yarns comprising of finer fibers, combed, waxed, Rotor spun, optimum twist and low linear density have lowest coefficient of friction of yarn, which ultimately improves subsequent textile processes and improve product qualities.

Keywords: Coefficient of friction, $L_{36}$ orthogonal design, linear density, Taguchi approach, yarn

\section{INTRODUCTION}

In this modern era of $21^{\text {st }}$ century, textile technologies are designed for higher rates of productivity to fulfill one of the basic needs of increasing human population, clothing. This imposes some serious restrictions on materials and equipment to produce quality product with highest efficiency and low downtimes. COF of yarns play an important role in textile fabrication, particularly in knitting where a combination of needles works together at high speeds and yarns pass through the hooks of needles. To produce faultless quality product, increase life of knitting needle and reduce yarn fluff in knitting process, COF of yarns must be lowest and within the tolerance level. In knitting, in our opinion, type of yarn material, spinning process and finishing method are the major impact factors need to be measured.

\section{RELATED LITERATURE}

Yarn formation is not as simple as its definition; it involves vast technologies, materials and influencing factors and used to produce wide range of textile products [1]. Frictional forces between yarns and knitting needles produce heat cause breakage of knitting needles and yarns [2]. An increase in yarn friction results in high end breakage rate at knitting and weaving [3]. Fiber parameters, yarn structural and bulk parameters, operational parameters and finishes are the major factors to affect the yarn frictional parameters [4]. Yarn twist is inversely while compressibility is found directly proportional to COF of yarn [5]. Rougher yarns have high COF in case of yarn-to-yarn while low COF in case of yarn to metal friction [6]. COF could be measured by Twist friction method, Capstan method, Amonton's law method, Lindberg and Gralen method [7]. Yarns with higher frictional properties gave fabrics whose frictional properties are proportionally higher [8].

Robust Design method, also called the Taguchi method, pioneered by Dr. Genichi Taguchi, focus on the effective application of engineering strategies, facilitates flexible designs and concurrent engineering [9].

Taguchi is a 4-phase process: Planning, Conducting, Analysis and Validation. Major tools used in Taguchi analysis are main effects plot for means, S/N ratio plots and results prediction for validation [10].

\section{DESIGN OF EXPERIMENT}

Rotor spun yarns are not waxed and compared to ring spun at single twist level that's why Taguchi is used twice, separate for ring and rotor spun yarns. Taguchi process is followed as:

Planning Phase - The problem is high COF causing troubles in sub-sequent knitting process and spinning complaints. The identified variables are; cotton type, yarn quality, yarn finish, linear density of yarn, twist 
level and yarn spinning technique. Five factors Taguchi is used for ring spun yarns while four factors design is used to compare ring spun and rotor spun yarns. Effecting variables and response factor for both designs is elaborated below.

Taguchi design for Ring spun yarns involve:

Rotor spun vs Ring spun yarns design involve:

\begin{tabular}{|c|c|c|c|c|}
\hline & & & & Table 1 \\
\hline \multicolumn{5}{|c|}{ DOE FOR RING SPUN YARNS } \\
\hline $\begin{array}{l}\text { Effecting } \\
\text { factors }\end{array}$ & \multicolumn{3}{|c|}{ Levels } & $\begin{array}{l}\text { Response } \\
\text { factor }\end{array}$ \\
\hline Cotton Type & \multicolumn{2}{|l|}{ Pakistani } & Indian & \multirow{5}{*}{ COF of Yarns } \\
\hline Yarn Quality & \multicolumn{2}{|l|}{ Carded } & Combed & \\
\hline Yarn Finish & Wax & \multicolumn{2}{|r|}{ Un-Wax } & \\
\hline T.M Level & 3.7 & 3.9 & 4.1 & \\
\hline Count & $16 s$ & $20 s$ & $24 s$ & \\
\hline
\end{tabular}

Table 2

\begin{tabular}{|c|c|c|c|}
\hline \multicolumn{4}{|c|}{ DOE FOR RING VS ROTOR SPUN YARN } \\
\hline $\begin{array}{l}\text { Effecting } \\
\text { factors }\end{array}$ & \multicolumn{2}{|c|}{ Levels } & $\begin{array}{c}\text { Response } \\
\text { factor }\end{array}$ \\
\hline Cotton Type & Pakistani & Indian & \multirow{4}{*}{ COF of Yarns } \\
\hline Yarn Quality & Carded & Combed & \\
\hline $\begin{array}{l}\text { Spinning } \\
\text { Technique }\end{array}$ & Ring & Rotor & \\
\hline Count & $16 s$ & $24 \mathrm{~s}$ & \\
\hline
\end{tabular}

Taguchi $L_{36}$ orthogonal array DOE is selected for both conditions.

Conducting Phase - As per DOEs, 72 experiments are performed to analyze their impact on COF of yarn. Experiments are performed under experimental lab conditions and tested according to ASTM Standards. Analysis Phase - Testing results are inserted in response factor column of Taguchi DOE and Taguchi is analyzed for means and $\mathrm{S} / \mathrm{N}$ ratios. Taguchi analysis shows effect of each variable on response factor and indicates optimum factors to achieve best results. Validation Phase - Results are validated by comparing nine random predicted values with Taguchi formulas and to actual experimental results.

\section{MATERIALS \& METHODS}

Raw cotton is tested for fiber parameters on USTER HVI 1000. 72 yarn samples are prepared according to Taguchi DOE. Samples development process flow is shown in figure 1.

\section{Testing}

Every sample is tested for Yarn Lea Strength, Tenacity on USTER Tensorapid, and COF on MESDAN ATTRIFIL-II, Uniformity and IPI on USTER UT-5 and yarn surface characteristics through SEM. Samples are tested for COF of yarn under ASTM-D1308 standard (table 3).

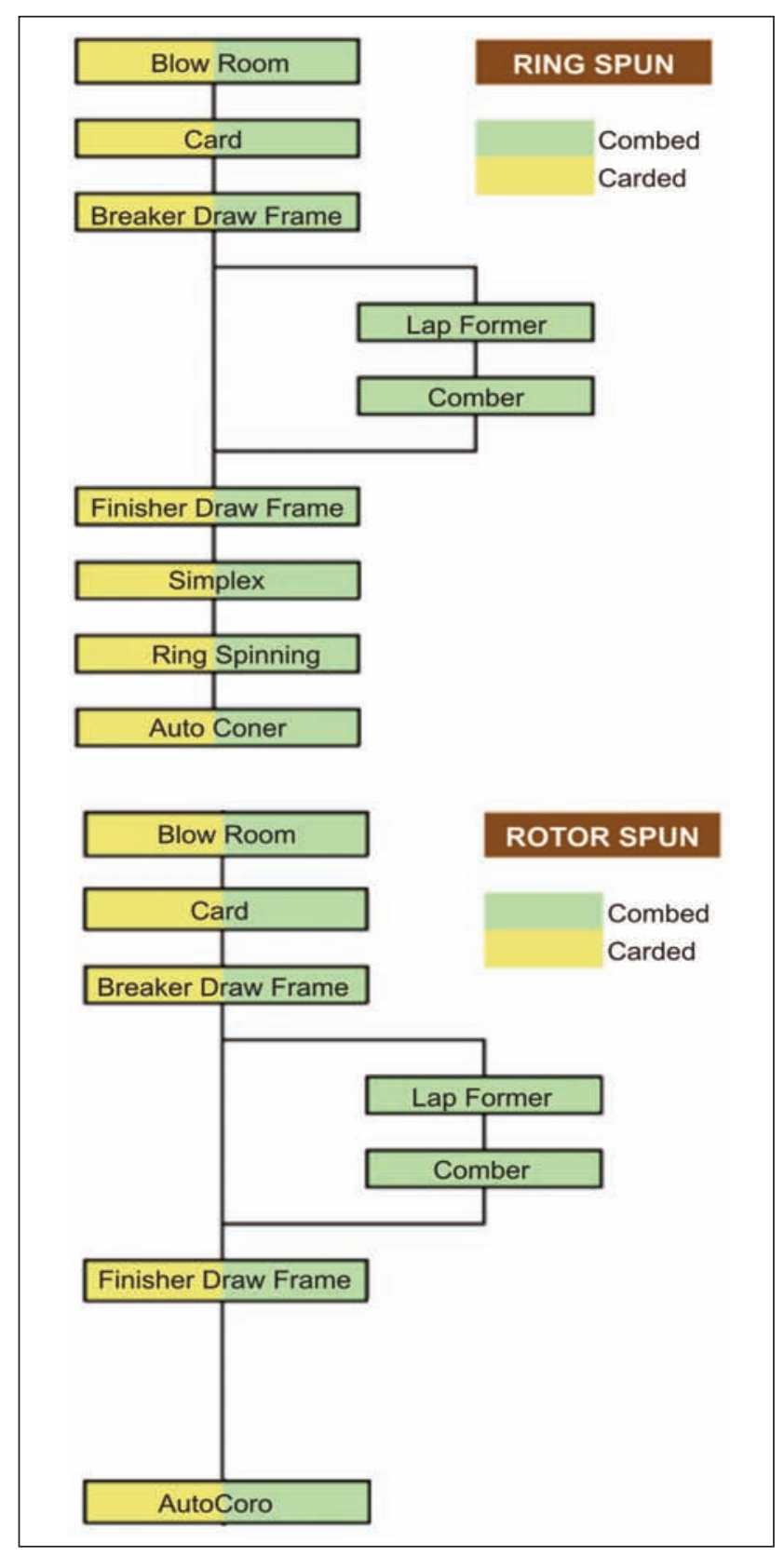

Fig. 1. Yarn Spinning Methods

Table 3

\begin{tabular}{|l|c|}
\hline \multicolumn{1}{|c|}{ COF Testing Parameter } & Value \\
\hline Number of tests each bobbin & 1 \\
\hline Sample length & $50 \mathrm{~m}$ \\
\hline Deviation among Tests & $10 \mathrm{~m}$ \\
\hline Input Tension & $20.0 \mathrm{cN}$ \\
\hline Sliding Speed & $150 \mathrm{~m} / \mathrm{min}$ \\
\hline
\end{tabular}

\section{ANALYSIS \& RESULTS}

Testing results are analyzed by using Taguchi Method in Minitab. COF of yarns is inserted in response column and analyzed against identified variables. Analysis results are explained below. Graph 1 shows that yarns spun from PAK Cotton have more friction than IND cotton. IND cotton has Mic. Value of 3.94 in contrast to 4.70 of PAK. High 
Mic. Value cause increase in contact area of the fibers and ultimately increase COF of yarns.

Carded yarns have more COF than combed yarns. Parallelization and orientation of fibers along the axis of yarn in reduce combed yarns. [12] Waxed yarns have lower COF than un-waxed yarns. Wax is a lubricant and gives smoother, slippery and unique yarn surface. SEM results have also validated this result. COF of yarns decreases with increase in indirect count. The fact is more compact structure of yarns due to fine count and high twist level. Structure that is more compact means low contact area and reduced COF. An increase is seen in COF of yarns at both low and high twist levels. This is due to the increased surface roughness and harshness of yarns at higher twist levels and more contact area due to low compactness at low twist levels. It is clear that COF is high at 3.7 and 4.1 T.M. level but low at 3.9. So, an optimum level is needed for better results.

Graph 2 represents that Rotor spun yarns have low COF than the Ring spun yarns. Rotor inserts twist inside to outside direction thus having high twist in core but low in surface due to which yarn surface is less harsh and more soft, results in lower COF of yarns. SEM results have also shown that Rotor spun yarn has smoother and even surface characteristics in contrast to Ring spun yarn. Scanning electron microscopy images for Ring spun (Waxed, Un-Waxed) and Rotor spun yarns are shown in figure 2 .

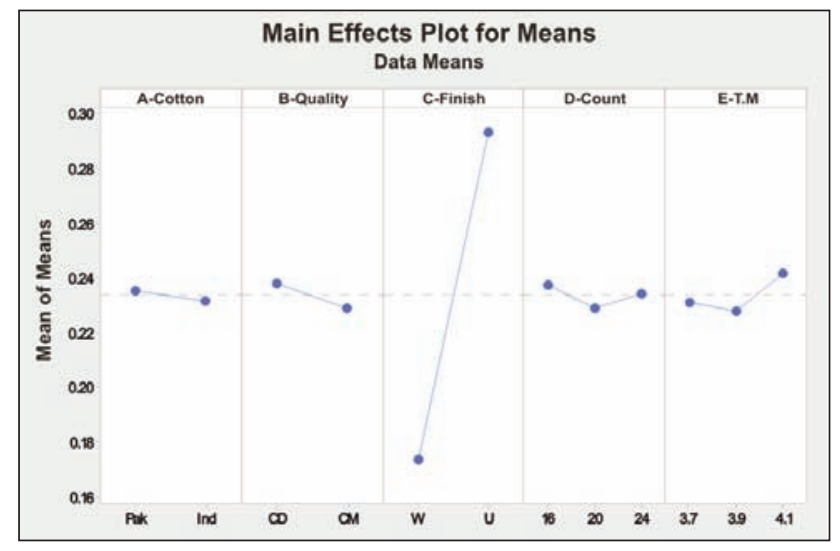

Graph 1. Main effects plot for Ring Spun Yarns

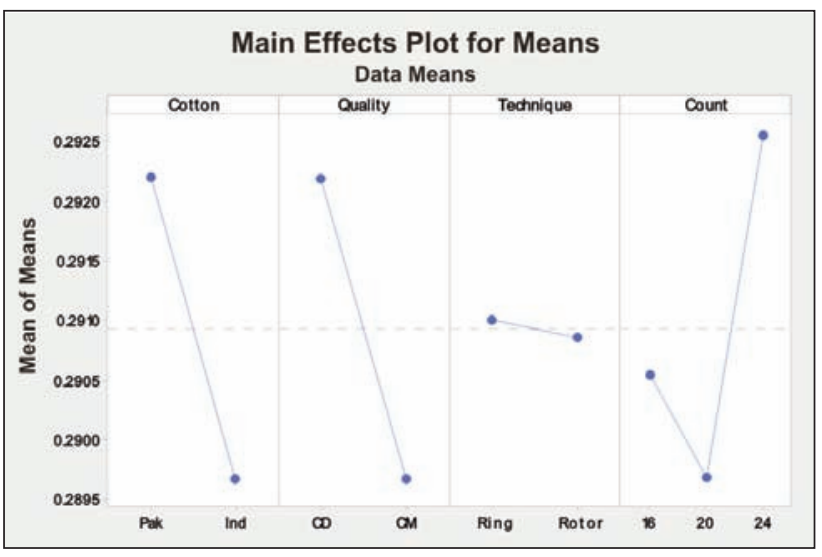

Graph 2. Main effects plot for Rotor Vs Ring Spun
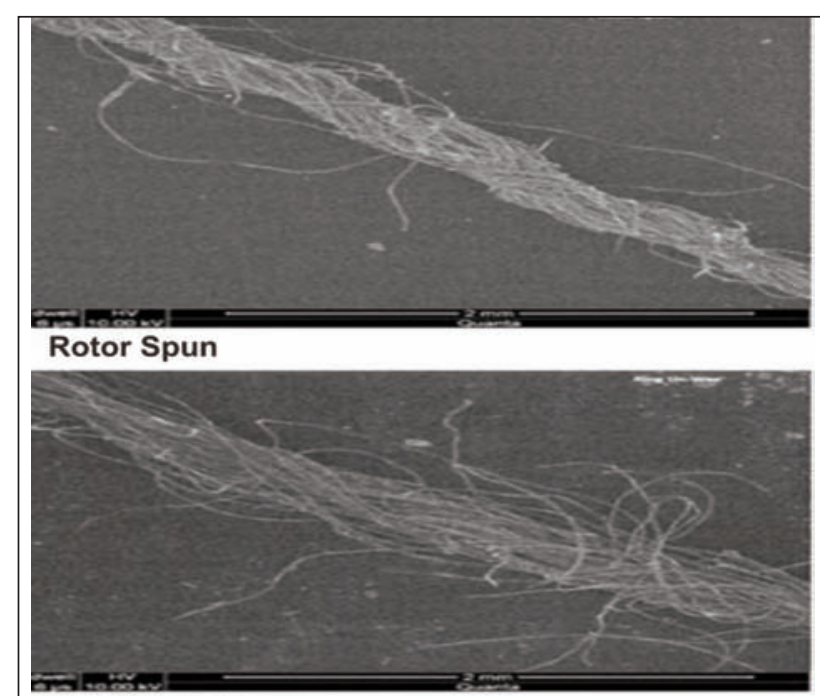

\section{Ring Spun Unwax}

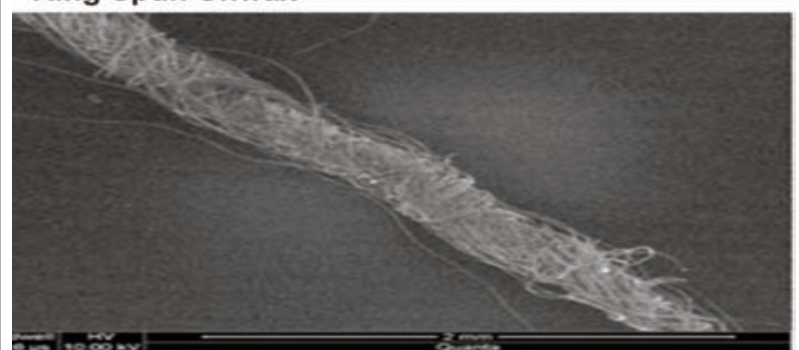

Ring Spun Wax

Fig. 2. SEM Images

\section{VALIDATION EXPERIMENT}

Verification experiment is performed under suggested factors, levels and conditions by $S / N$ ratios graph and tables in Taguchi analysis. The results of this experiment are then compared with the predicted value calculated by formula 1 .

$$
\eta=\eta_{m}+\sum_{i=1}^{j}\left(\eta_{i}-\eta_{m}\right)
$$

$S / N$ ratio graph produced in Taguchi analysis of Ring spun yarns is shown below:

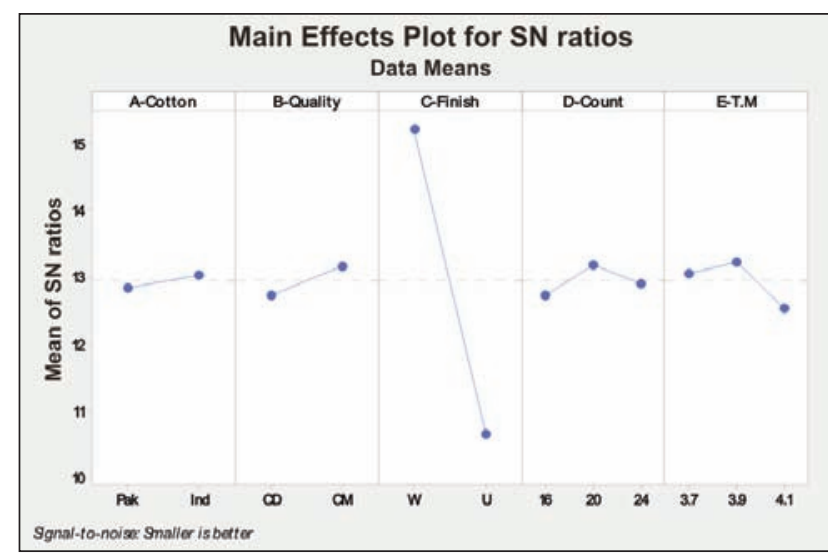

Graph 3. SN Ratios Plot for Ring Spun

It is elaborated from the $S / N$ ratios graph that IND cotton, CMB yarn, 20s and 3.9 T.M level give the best results. Therefore, these are the suggested levels of 
impact factors. The mean value $\eta_{m}$ of multiple $S / N$ ratios in all experiments is 13.015 in graph.

Response table for suggested $S / N$ ratios generated by Minitab in Taguchi analysis is:

Table 4

\begin{tabular}{|c|c|c|c|c|c|}
\hline \multicolumn{6}{|c|}{ SN RATIOS RESPONSE TABLE } \\
\hline \multirow{2}{*}{$\begin{array}{c}\text { Factors } \\
\text { levels }\end{array}$} & \multicolumn{5}{|c|}{ Average SN } \\
\hline & $\begin{array}{c}\text { A- } \\
\text { Cotton }\end{array}$ & $\begin{array}{c}\text { B- } \\
\text { Quality }\end{array}$ & $\begin{array}{c}\text { C- } \\
\text { Finish }\end{array}$ & $\begin{array}{c}\text { D- } \\
\text { Count }\end{array}$ & E-T.M \\
\hline 1 & 12.84 & 12.72 & 15.23 & 12.74 & 13.06 \\
\hline 2 & 13.04 & 13.15 & 10.63 & 13.18 & 13.22 \\
\hline 3 & - & - & - & 12.90 & 12.53 \\
\hline Delta & 0.20 & 0.43 & 4.57 & 0.44 & 0.69 \\
\hline Rank & 5 & 4 & 1 & 3 & 2 \\
\hline
\end{tabular}

It is clear from the table that finish is ranked $1^{\text {st }}$ as an effecting factor for COF while cotton is ranked last. So, the best optimum parameters combination is A2:B2: C1:D2: E2 which means IND: CMB: Wax: 20s:3.9. Now the predicted value is calculated by the formula as:

$$
\begin{aligned}
\eta_{O}=13.015 & +(13.04-13.015) \\
& +(13.15-13.015) \\
& +(15.23-13.015) \\
& +(13.18-13.015) \\
& +(13.22-13.015) \\
& =15.76
\end{aligned}
$$

Now the $S / N$ value is known and predicted value for COF of yarn at this $S / N$ ratio is calculated by following formula 2 :

$$
S / N=-10 \log \left(\frac{1}{n} \sum_{i=1}^{n} \mathrm{y}_{i}^{2}\right)
$$

The predicted value is:

$$
15.76=-10 \log \left(\frac{1}{36} \sum_{i=1}^{n} \mathrm{y}_{i}^{2}\right) \Rightarrow \mathrm{y}_{i}=0.1632
$$

Now experimental value of COF of sample (IND: CMB: Wax: 20s:3.9) is measured and the COF value of yarn is 0.1535 which is close and better to the predicted value by Taguchi design (0.1632).

$\mathrm{S} / \mathrm{N}$ ratio graph produced in Taguchi analysis of Ring Vs Rotor spun yarns is shown bellow:

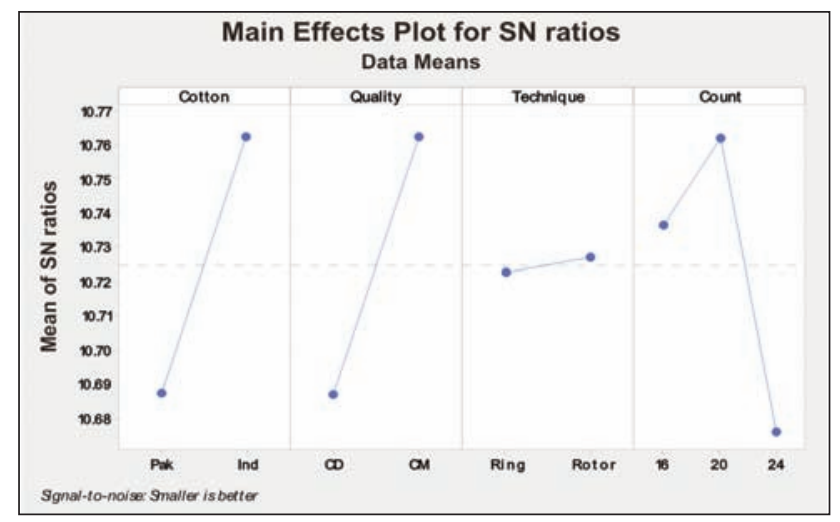

Graph 4. SN Ratios Plot for Rotor Spun
It is elaborated from the $S / N$ ratios graph that IND cotton, CMB yarn, 20s count and rotor give the best results. The mean value $\eta_{m}$ of multiple $S / N$ ratios in all experiments is 10.7248 in graph. Response table for suggested $S / N$ ratios generated by Minitab in Taguchi analysis is:

Table 5

\begin{tabular}{|c|c|c|c|c|}
\hline \multicolumn{5}{|c|}{ SN RATIOS RESPONSE TABLE } \\
\hline \multirow{2}{*}{$\begin{array}{c}\text { Factors } \\
\text { levels }\end{array}$} & \multicolumn{5}{c|}{ Average SN } \\
\cline { 2 - 5 } & A-Cotton & B-Quality & C-Finish & D-Count \\
\hline 1 & 10.69 & 10.69 & 10.72 & 10.74 \\
\hline 2 & 10.76 & 10.76 & 10.73 & 10.76 \\
\hline 3 & - & - & - & 10.68 \\
\hline Delta & 0.08 & 0.08 & 0.01 & 0.09 \\
\hline Rank & 3 & 2 & 4 & 1 \\
\hline
\end{tabular}

It is clear from the table that count is ranked $1^{\text {st }}$ as an effecting factor for COF while technique is ranked last. So, the best optimum parameters combination is A2:B2: C2:D2 which means Indian: Combed: Rotor:20s. Now the predicted value is calculated by the formula as:

$$
\begin{aligned}
\eta_{O}=10.7248 & +(10.76-10.7248) \\
& +(10.76-10.7248) \\
& +(10.73-10.7248) \\
& +(10.76-10.7248) \\
& =10.8356
\end{aligned}
$$

Now the value of $S / N$ is known and predicted value for COF of yarn at this $S / N$ ratio is calculated by formula. The predicted value is:

$$
10.8356=-10 \log \left(\frac{1}{36} \sum_{i=1}^{n} \mathrm{y}_{i}^{2}\right) \Rightarrow \mathrm{y}_{i}=0.2898
$$

Now experimental value of COF of sample (Indian: Combed:Rotor:20s:) is measured and the COF value of yarn is 0.2895 which is very close to the predicted value by Taguchi design (0.2898).

\section{PREDICTION OF THE COF OF OTHER CONDITION USING TAGUCHI DESIGN}

Similarly, predicted and experimental values ae compared for nine conditions for each ring spun yarns

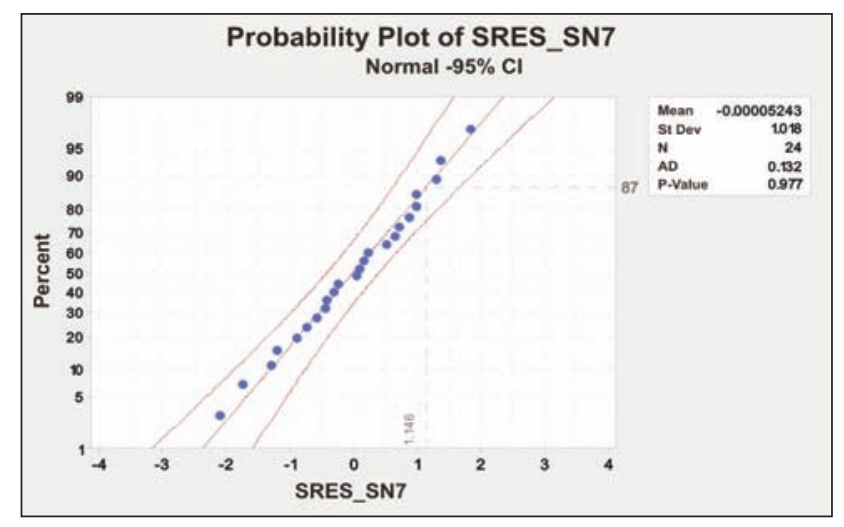

Graph 5. Normal Probability Plot for Residuals 
which shows $3.35 \%$ variation and ring vs rotor spun yarns which shows $0.37 \%$ variation.

Normal probability plot has shown that residuals generally fall in a straight line and errors are distributed normally inside the outer limits. So, relative percentage errors are low and all experimental results are normal.

\section{CONCLUSIONS}

It is concluded that: the fineness, parallelization and compactness of fibers inside yarn structure are directly proportional to the COF of yarns, also demonstrated in a recent research [13]. Another research validates the yarn smoothness due to fineness and compactness [11]. SEM images and COF results have elaborated that wax reduces COF of yarns acting as an effective lubricant. Best COF values of yarns achieved at optimum twist level not too low or high depicts that COF of yarns increase at both low and high twist levels. Yarn structure and twisting technique show robust impact on COF of yarns as rotor spun yarns were found superior than the ring spun yarns in case of COF. Experimental verification and graphs have shown that there are very little errors between experimental and predicted values. Moreover, Taguchi design is proved as a powerful tool to analyze, predict, compare and find errors. At the end the normal probability plot for residuals elaborate that all the results lie on the straight line within the normal limits. These results are also supported by previous researches [4-6].

\section{BIBLIOGRAPHY}

[1] Sheppard, Laurel M. How yarn is made - material, manufacture, making, history, used, processing, parts, industry, machine, History, 2008. [Online]. Available: http://www.madehow.com/Volume-3/Yarn.html. [Accessed: 13-Aug2016].

[2] Tia Ghose, S. W. What is Friction? | Friction Definition, 2013. [Online]. Available: http://www.livescience.com/37161what-is-friction.html. [Accessed: 12-Aug-2016].

[3] USTER, "Friction measurement," March, 2010.

[4] Yarn friction \& its importance, theory, factors, measurement | Spinning \& Weaving | Features | The ITJ. [Online]. Available: http://www.indiantextilejournal.com/articles/FAdetails. asp?id=4199. [Accessed: 31-Dec-2015].

[5] Road, A. and Design, A. Studies on friction in cotton textiles : Part I - A study on the relationship between physical properties and frictional characteristics of cotton fibres and yarns, In: Indian J. Fiber Text. Res., vol. 38, September, pp. 244-250, 2013.

[6] Ghosh, A., Patanaik, A., Anandjiwala, R. D. and Rengasamy, R. S. A study on dynamic friction of different spun yarns, In: Applied Polymer, vol. 108, pp. 3233-3238, 2008.

[7] Study of yarn coefficient of friciton to smoothness hand value, 2010.

[8] Ajayi, R. and Studies, C. Comparative studies of yarn and fabric friction, In: Journal of Testing and Evaluation, vol. 22, no. 5, pp. 465-469, 1994.

[9] Phadke, Madhav S. Introduction to robust design (Taguchi Method), 2015. [Online]. Available: https://www.isixsigma.com/methodology/robust-design-taguchi-method/introduction-robust-design-taguchi-method/. [Accessed: 12-Aug-2016].

[10] Mavruz, S. and Ogulata, R. T. Taguchi approach for the optimisation of the bursting strength of knitted fabrics, In: Fibres Text. East. Eur., vol. 79, no. 2, pp. 78-83, 2010.

[11] Unal, G. P., \& Nilgun, O. Analysis of cotton ring spun yarn diameter using regression and artifical neural network, In: Industria Textila, 2015, Vol. 66, no. 6, pp. 317-721.

[12] Hosseinali, F. Variability of fiber friction among cotton varieties: Influence of salient fiber physical metrics, In: Tribology International, vol. 127, pp. 443-445, 2018.

[13] Azam Alirezazadeh, Mohammad Zarrebini, Mohammad Ghane \& Parham Soltani, Fiber-on-fiber friction measurement using hanging, In: The Journal of The Textile Institute, vol. 109, no. 5, pp. 636-646, 2017.

\section{Authors:}

\section{MOHSIN MUHAMMAD ${ }^{1}$, NAI-WEN LI ${ }^{2}$, SOHAIL ANJUM MUHAMMAD ${ }^{3}$, KASHIF MAJEED MUHAMMAD 4}

${ }^{1} \mathrm{PhD}$ Scholar College of Business Administration Liaoning Technical University, Liaoning, 125105, China

${ }^{2}$ College of Business Administration, Liaoning Technical University, Liaoning, 125105, China

${ }^{3}$ officer Knitting, Textile Engineer \& Researcher at Interloop Ltd. Texlan Center Pvt. Ltd. Sir Lanka

${ }^{4} \mathrm{PhD}$ Scholar Liaoning Technical University, Liaoning, 125105, China

Corresponding author:

MOHSIN MUHAMMAD

e-mail: mohsinlatifntu@gmail.com 


\section{Effects of waste cotton usage on properties of OE-rotor yarns and knitted fabrics}

DOI: $10.35530 / I T .070 .03 .1560$

MUSA KILIC

GONCA BALCI KILIC

H. KÜBRA KAYNAK

EFLATUN TIRYAKI

MURAT DEMIR

\section{REZUMAT - ABSTRACT}

Efectele utilizării deșeurilor de bumbac asupra proprietăților firelor filate cu rotor OE și ale materialelor tricotate

Utilizarea materialelor reciclate a câștigat o importanță masivă atât în sectorul textil, precum și în alte sectoare, deoarece efectele reducerii surselor naturale sunt resimțite peste tot în lume. În acest studiu, s-a urmărit analizarea efectelor utilizării bumbacului reciclat asupra proprietăților firelor filate cu rotor OE și a tricoturilor realizate din aceste fire. În acest scop, firele filate cu rotor $O E$ au fost produse în diferite amestecuri de bumbac virgin și deșeuri de bumbac care provin din bataj, în proporție de 25\%, 50\%, 75\%, și respectiv 100\%. Pentru o evaluare mai bună, proprietățile firelor filate cu rotor OE care conțin deșeuri de bumbac au fost comparate cu firele filate cu rotor OE din bumbac virgin. Proprietățile fizice, structurale și mecanice, cum ar fi neuniformitatea, imperfecțiunile, pilozitatea, forța de rupere, alungirea, frecarea fir-fir, frecarea fir-metal și frecarea fir-ceramică, au fost măsurate cu Uster Tester 4 SX, Uster Zweigle Hairiness Tester 5, Uster Tensorapid 3 și CTT Lawson Hemphill. În cea de-a doua parte a studiului, au fost realizate tricoturi glat din firele filate cu rotor OE. Au fost evaluate, de asemenea, efectele ponderii deșeurilor reciclate asupra proprietăților țesăturii tricotate, cum ar fi pilingul, rezistența la abraziune, rezistența la plesnire și permeabilitatea la aer. Rezultatele au arătat că utilizarea a până la $75 \%$ în amestec a bumbacului reciclat nu prezintă diferențe semnificative din punct de vedere statistic în ceea ce privește proprietățile firelor și țesăturilor.

Cuvinte-cheie: bumbac reciclat, deșeuri de bumbac, filare cu rotor OE, fire în amestec, proces sustenabil de producție

\section{Effects of waste cotton usage on properties of OE-rotor yarns and knitted fabric}

The use of recycled materials has gained massive importance in textile sector as well as in other sectors as the effects of reduction of natural sources are felt all over the world. In this study, it was aimed to analyse the effects of recycled cotton usage on properties of OE-rotor spun yarns and knitted fabrics produced from these yarns. For this purpose, OE-rotor yarns were produced at different proportion levels of virgin cotton and waste cotton that derived from blowroom $25 \%, 50 \%$, $75 \%, 100 \%$, respectively. For better assessment, properties of OE-rotor yarns that contain waste cotton were compared with $100 \%$ virgin cotton OE rotor yarn. Physical, structural and mechanical properties such as unevenness, imperfections, hairiness, breaking force, elongation, yarn-to-yarn friction, yarn-to-metal friction and yarn-to-ceramic friction were measured by Uster Tester 4 SX, Uster Zweigle Hairiness Tester 5, Uster Tensorapid 3 and CTT by Lawson Hemphill. At the second part of the study, single-jersey knitted fabrics were produced from OE-rotor spun yarns. Effects of waste cotton proportion on knitted fabric properties such as pilling, abrasion resistance, bursting strength and air permeability were also evaluated. Results showed that, the use of up to $75 \%$ per cent of waste cotton blended yarns show no statistically significant differences on yarn and fabric properties.

Keywords: recycled cotton, waste cotton, OE-rotor spinning, blended yarns, sustainable production process

\section{INTRODUCTION}

Textile industry is one of the major sectors that scope all over the world and consumption level of textile products have been rising year by year as a consequence of growth of the world population and improvements of living standards [1]. Cotton keeps its position as a main raw material for textile industry despite of recent improvements of synthetic and regenerated fibres [2]. The other point of view, production level of cotton has been fluctuated for recent years, and because of strict relation with geographical condition, it is hard to estimate production level of cotton for upcoming years [3].
By the relation with cotton position in textile industry, efficient waste management plays major role for cost of textile product. In order to reduce production costs and obtain sustainable and ecological production processes as well as to prevent harmful effects of cotton farming such as release of carbon dioxide, water and energy consumption, many multinational textile suppliers begin to use recycled or waste cotton [4-6]. With the rising concern of global warming and reduces of natural sources, some protocols i.e. Kyoto and Montreal are put into effect in order to protect environment and prevent release of greenhouse gases. Moreover, international organisations such as Global Organic Textile Standard (GOTS), Better 
Cotton Iniative $(\mathrm{BCl}), e^{3}$ Sustainably Grown Cotton, Cotton Leads focus on sustainable production process of textile products as well as provide cotton farming in better ecologic environment. On the other hand, products that produced from recycled materials find position between many consumers' first consumption choices and create their own market share known as "green market" or "environmental marketing" [7].

In the literature, it is seen that many researchers produced open-end rotor spun yarns by using recycled cotton. It can be related with the reason of capability of rotor spun technology to produce yarn from cotton waste at high twist level unlike other spinning technologies. Hassani et al. investigated the optimum spinning conditions for rotor spun yarns that different proportional cotton wastes derived from ginning machines blended with secondary raw material [8]. Khan et al. studied on the prediction of the properties of cotton/waste blended OE rotor spun yarns using Taguchi OA design [9]. They concluded that the proportion amount of waste cotton is the most influential parameter on the properties of cotton/waste blended yarns. Taher et al. analysed the influence of spinning parameters and recover fibres from cotton waste on the uniformity and hairiness of rotor spun yarns [10]. They indicated that yarn count, rotor parameters such as diameter, form and rotor speed have considerable effects as much as waste proportion. Furthermore, they also denoted that using $25 \%$ of recycle fibre does not change the uniformity and appearance of rotor spun yarn in their study. Halimi et al. also examined the effect of cotton waste and spinning parameters on the rotor yarn quality [11]. Results of their study also verified that up to between $15 \%$ and $25 \%$ cotton waste ratio does not cause any change on rotor yarn quality with the optimum spinning parameters. Hassani and Tabatabei focused on optimising of spinning variables in order to reduce hairiness of rotor yarn produced from waste fibres that collected from ginning process [12]. According to conclusions of study, rotor diameter and navel type have significantly higher effect than other production parameters on the hairiness of rotor spun yarn with all proportion levels $(65 \%, 50 \%, 35 \%)$ of waste cotton. Halimi et al. investigated proportion of good fibres inside cotton wastes that derived from blow room and card machines using both of the qualitative and quantitative methods [13]. In order to determine cotton wastes as a good fibre, OE rotor yarns produced and analysed. Results showed that between $15 \%$ and $25 \%$ cotton wastes can be blended with virgin cottons without noticeable drawbacks on rotor yarn quality. Celep et al. presented an experimental study on the thermal comfort properties of single jersey knitted fabrics that produced from $100 \%$ virgin cotton, $\% 100$ recycled cotton, $50 \%-50 \%$ recycled-virgin cotton OE yarns [14]. Regarding the comparative analysis between samples, it is seen that thermal conductivity, thermal absorptivity, air permeability decreased and thermal resistance increased with the increased proportion of recycled cotton fibres. Vadicherla and Saravanan were also studied thermal comfort properties of single jersey knitted fabrics that contain different ratios of recycled polyester and cotton blended yarns [15]. It was seen from their study that fabrics become thinner, lighter, more porous with higher thermal conductivity, air permeability and less thermal resistance with increasing ratio of recycled polyester.

Aim of this study is to investigate how cotton waste proportion effects yarn and fabric quality and propose an optimum blend ratio for effective waste management. For this purpose, OE-rotor spun yarns were produced at different proportions of virgin and waste cotton that was obtained from blow-room and single jersey knitted fabrics were also produced from all yarn types.

\section{EXPERIMENTAL}

In this study, Ne 22/1 OE-rotor yarns with $\alpha_{e}=4.2$ twist level were produced from $100 \%$ virgin cotton, $100 \%$ waste cotton and virgin-waste cotton blends (75\%-25\%,50\%-50\% and $25 \%-75 \%$ ). Turkish cotton was used as virgin cotton and waste cotton was obtained from blowroom. HVI values of Turkish cotton are shown in table 1.

\begin{tabular}{|c|c|}
\hline \multicolumn{2}{|c|}{ Table 1 } \\
\hline \multicolumn{2}{|c|}{ HVI VALUES OF VIRGIN COTTON } \\
\hline Property & Value \\
\hline Micronaire (mg/inch) & 4.29 \\
\hline Maturity & 0.88 \\
\hline Length (mm) & 28.56 \\
\hline Uniformity (\%) & 82 \\
\hline Short Fibre Index (SFI) & 8.0 \\
\hline Strength (cN/tex) & 32.1 \\
\hline Elongation (\%) & 7.5 \\
\hline
\end{tabular}

Ne 0.12 slivers were produced after two drawframe passages. In OE-rotor yarn production, rotor and opening roller revolutions were 95000 and $8600 \mathrm{rpm}$, respectively. Physical, structural and mechanical properties of these yarns were measured by Uster Tester 4 SX, Uster Zweigle Hairiness Tester 5, Uster Tensorapid 3 and Lawson Hemphill CTT.

At the second part of the study, single-jersey knitted fabrics were produced from OE-rotor yarns. Effects of waste cotton proportion on knitted fabric properties such as pilling, abrasion resistance, bursting strength and air permeability were also evaluated. Abrasion resistance and pilling tendency tests were performed using James $\mathrm{H}$. Heal Nu-Martindale Abrasion and Pilling Tester. The weight losses ( $\%$ and $\mathrm{mg}$ ) and changes of thickness (\% and $\mathrm{mm}$ ) of the samples were calculated at the end of 15000 cycles to measure the abrasion resistance of the fabrics. Pilling tendencies of fabrics were determined in accordance 
with ISO 12945:2. In this method, ratings for tested samples were determined by comparing with standard photographs. " 5 " rating shows that there is no visible change on the surface of the fabric. Bursting strength tests were performed by James $\mathrm{H}$. Heal TruBurst Bursting Strength Tester by using $7.3 \mathrm{~cm}^{2}$ test area according to ASTM D3786/D3786M-13. Air permeability values of fabrics were measured in accordance with ISO 9237 using $20 \mathrm{~cm}^{2}$ test area and $100 \mathrm{~Pa}$ test pressure.

\section{RESULTS AND DISCUSSION}

\section{Evaluation of yarn properties}

For a better understanding of how usage of waste cotton affects quality of OE-rotor spun yarns, properties such as unevenness, imperfections, hairiness, breaking force, breaking elongation and friction (yarn-to-yarn, yarn-to-metal and yarn-to-ceramic) were analysed statistically using ANOVA and confidence interval graphs at $95 \%$ confidence level.

\section{Unevenness}

Figure 1 shows the effect of waste cotton proportion on yarn unevenness. Unevenness and proportion of waste cotton show parallel increase due to the increasing amount of short fibre in the yarn. Moreover, there is no statistically significant difference amongst the blended yarns up to $75 \%$ waste content.

Table 2 shows the ANOVA results and table 3 shows the pairwise comparisons of the yarn types. As it is indicated in table 2, waste cotton usage is statistically significant on yarn unevenness $(p=0.007)$. Moreover, results in table 3 shows that there is no

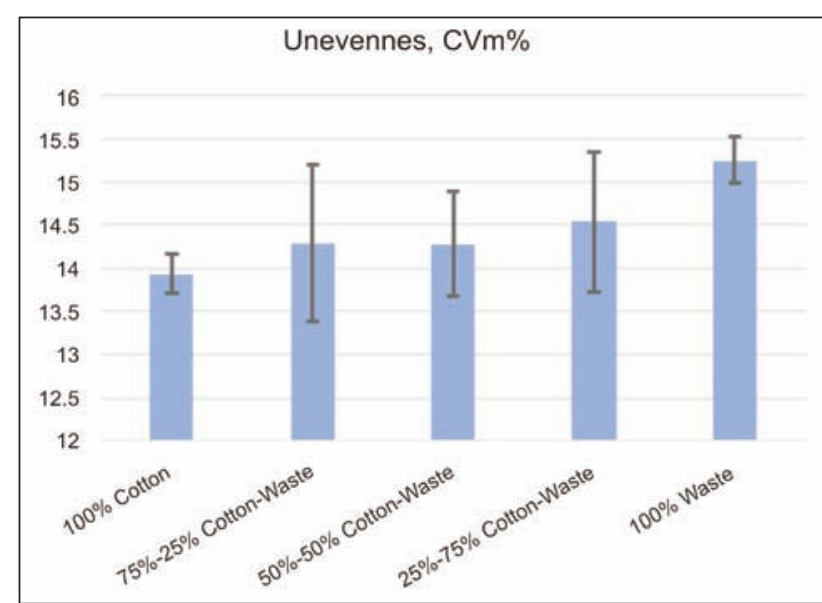

Fig. 1. Unevenness (CVm\%) values and 95\% confidence intervals

statistically significant difference between 100\% cotton, $75 \%-25 \%, 50 \%-50 \%$ and $25 \%-75 \%$ cotton-waste yarns. Only $100 \%$ cotton waste yarns show statistically significant difference with other yarn types $(p<0.05)$.

\section{Imperfections}

The effects of waste cotton proportion on imperfections are illustrated in figure 2. As it is seen from the figure, the number of thin places and thick places which are more likely related with drafting system do not show statistically significant difference regarding the proportion of waste cotton. Comparing neps values shows that $100 \%$ waste cotton have the greatest value and it might be related with amount of immature cotton fibres in yarn structure.

\begin{tabular}{|c|c|c|c|c|c|}
\hline \multicolumn{7}{|c|}{ ANOVA RESULTS FOR UNEVENNESS (CVM\%) VALUES } \\
\hline Source & Type III Sum of Squares & df & Mean Square & F & Sig. \\
\hline Corrected Model & $4.847^{\mathrm{a}}$ & 4 & 1.212 & 4.754 & .007 \\
\hline Intercept & 5225.460 & 1 & 5225.460 & 20499.087 & .000 \\
\hline Yarn Type & 4.847 & 4 & $\mathbf{1 . 2 1 2}$ & 4.754 & .007 \\
\hline Error & 5.098 & 20 & .255 & & \\
\hline Total & 5235.405 & 25 & & & \\
\hline Corrected Total & 9.945 & 24 & & & \\
\hline a R Squared $=.487$ (Adjusted R Squared $=.385)$ & & & & \\
\hline
\end{tabular}
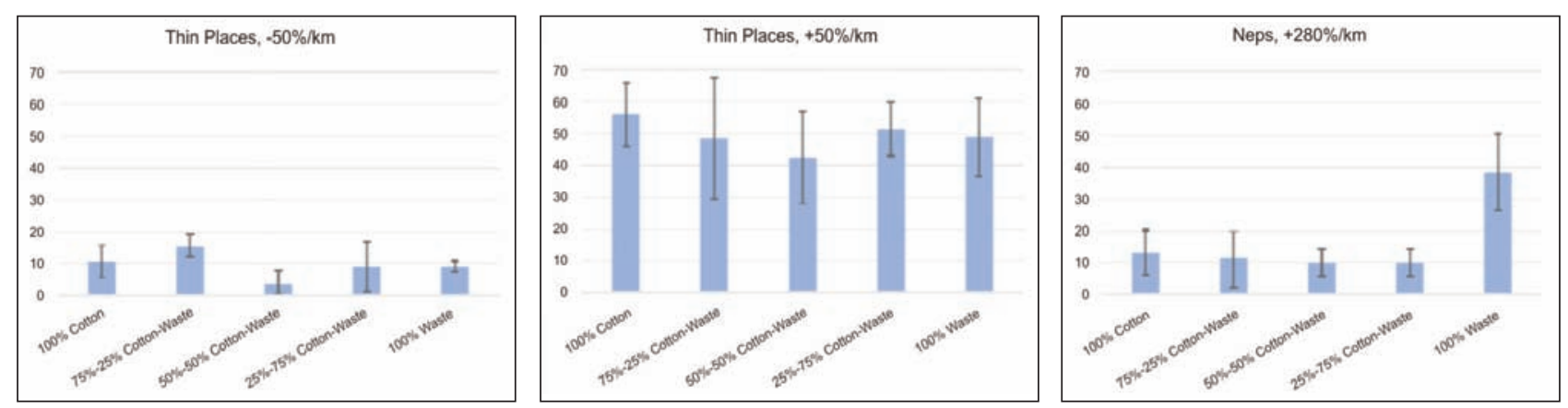

Fig. 2. Imperfections (thin places, thick places and neps) and $95 \%$ confidence intervals 


\begin{tabular}{|c|c|c|c|c|c|c|}
\hline \multicolumn{7}{|c|}{ PAIRWISE COMPARISONS FOR UNEVENNESS (CVM\%) VALUES } \\
\hline \multirow{2}{*}{ (I) Raw } & \multirow{2}{*}{$\begin{array}{l}\text { (J) Raw } \\
\text { Material }\end{array}$} & \multirow{2}{*}{$\begin{array}{c}\text { Mean } \\
\text { Difference } \\
(\mathrm{I}-\mathrm{J})\end{array}$} & \multirow{2}{*}{ Std. Error } & \multirow{2}{*}{ Sig. ${ }^{b}$} & \multicolumn{2}{|c|}{$\begin{array}{l}\text { 95\% Confidence Interval for } \\
\text { Difference }^{\text {b }}\end{array}$} \\
\hline & & & & & Lower bound & Upper bound \\
\hline \multirow[t]{4}{*}{$\% 100$ Cotton } & $\% 25$ Waste & -0.370 & 0.319 & 0.260 & -1.036 & 0.296 \\
\hline & $\% 50$ Waste & -0.350 & 0.319 & 0.286 & -1.016 & 0.316 \\
\hline & $\% 75$ Waste & -0.596 & 0.319 & 0.077 & -1.262 & 0.070 \\
\hline & $\% 100$ Waste & $-1.321^{*}$ & 0.319 & 0.001 & -1.987 & -0.655 \\
\hline \multirow[t]{4}{*}{$\% 25$ Waste } & $\% 100$ Cotton & 0.370 & 0.319 & 0.260 & -0.296 & 1.036 \\
\hline & $\% 50$ Waste & 0.020 & 0.319 & 0.951 & -0.646 & 0.686 \\
\hline & $\% 75$ Waste & -0.226 & 0.319 & 0.487 & -0.892 & 0.440 \\
\hline & $\% 100$ Waste & $-0.951^{*}$ & 0.319 & 0.007 & -1.617 & -0.285 \\
\hline \multirow[t]{4}{*}{$\% 50$ Waste } & $\% 100$ Cotton & 0.350 & 0.319 & 0.286 & -0.316 & 1.016 \\
\hline & $\% 25$ Waste & -0.020 & 0.319 & 0.951 & -0.686 & 0.646 \\
\hline & $\% 75$ Waste & -0.246 & 0.319 & 0.450 & -0.912 & 0.420 \\
\hline & \%100 Waste & $-0.971^{*}$ & 0.319 & 0.006 & -1.637 & -0.305 \\
\hline \multirow[t]{4}{*}{$\% 75$ Waste } & $\% 100$ Cotton & 0.596 & 0.319 & 0.077 & -0.070 & 1.262 \\
\hline & $\% 25$ Waste & 0.226 & 0.319 & 0.487 & -0.440 & 0.892 \\
\hline & $\% 50$ Waste & 0.246 & 0.319 & 0.450 & -0.420 & 0.912 \\
\hline & $\% 100$ Waste & $-0.725^{*}$ & 0.319 & 0.034 & -1.391 & -0.059 \\
\hline \multirow[t]{4}{*}{$\% 100$ Waste } & $\% 100$ Cotton & $1.321^{*}$ & 0.319 & 0.001 & 0.655 & 1.987 \\
\hline & \%25 Waste & $0.951^{*}$ & 0.319 & 0.007 & 0.285 & 1.617 \\
\hline & $\% 50$ Waste & $0.971^{*}$ & 0.319 & 0.006 & 0.305 & 1.637 \\
\hline & $\% 75$ Waste & $0.725^{*}$ & 0.319 & 0.034 & 0.059 & 1.391 \\
\hline \multicolumn{7}{|c|}{ Based on estimated marginal means } \\
\hline \multicolumn{7}{|c|}{${ }^{*}$ The mean difference is significant at the .05 level } \\
\hline Adjustmen & multiple com & ns: Least & nt Diffe & & di. at a a & \\
\hline
\end{tabular}

\section{Hairiness}

Figure 3 demonstrates the hairiness values $(\mathrm{H}$ and $\mathrm{S} 3$ ) of OE-rotor yarns. As it is seen from the figure, $\mathrm{H}$ values increase but $\mathrm{S} 3$ values decrease while the waste cotton proportion increases. The main reason behind this situation should be the difference between measuring principles of $\mathrm{H}$ and $\mathrm{S} 3$ values. $\mathrm{H}$ value is total length of all protruding fibres along the yarn, while $S 3$ value is the count of the fibres longer than $3 \mathrm{~mm}$. The increasing ratio of waste cotton means more amount of shorter fibres take place around the yarn surface, so that $\mathrm{H}$ and $\mathrm{S} 1+2$ values increase. On the other hand, decreasing total staple length cause decreasing S3 value.

\section{Breaking force and elongation}

Figure 4 shows breaking force and breaking elongation values. $100 \%$ waste cotton yarns have the lowest breaking force and elongation values and it is
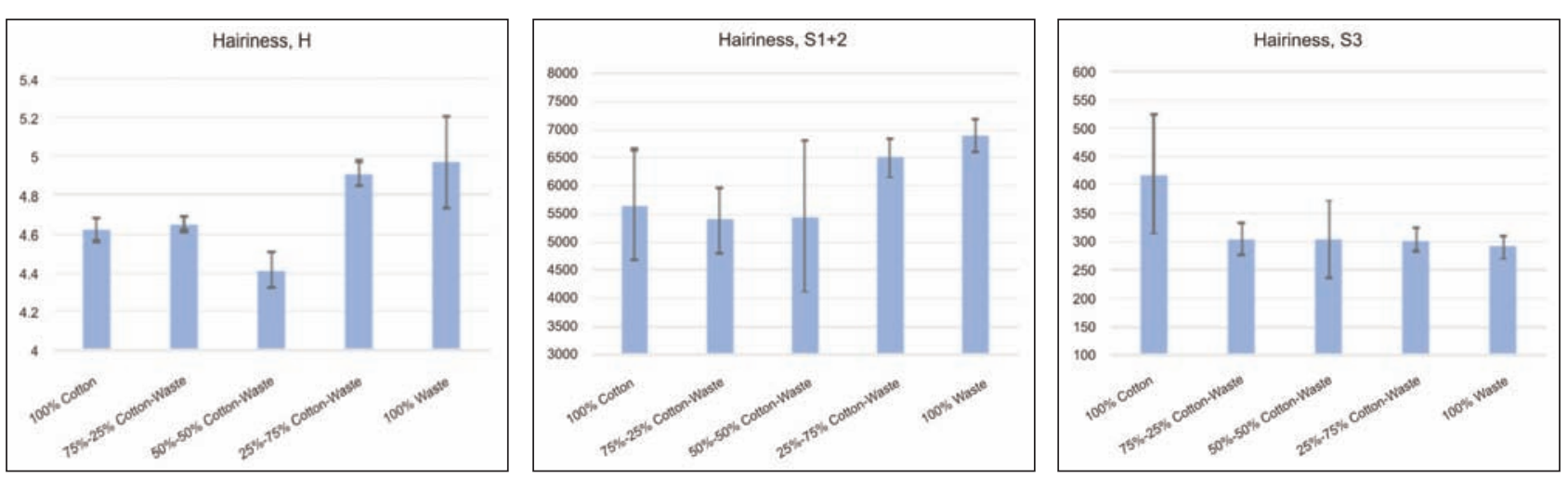

Fig. 3. Hairiness $(H, S 1+2$ and $S 3)$ values and $95 \%$ confidence intervals 

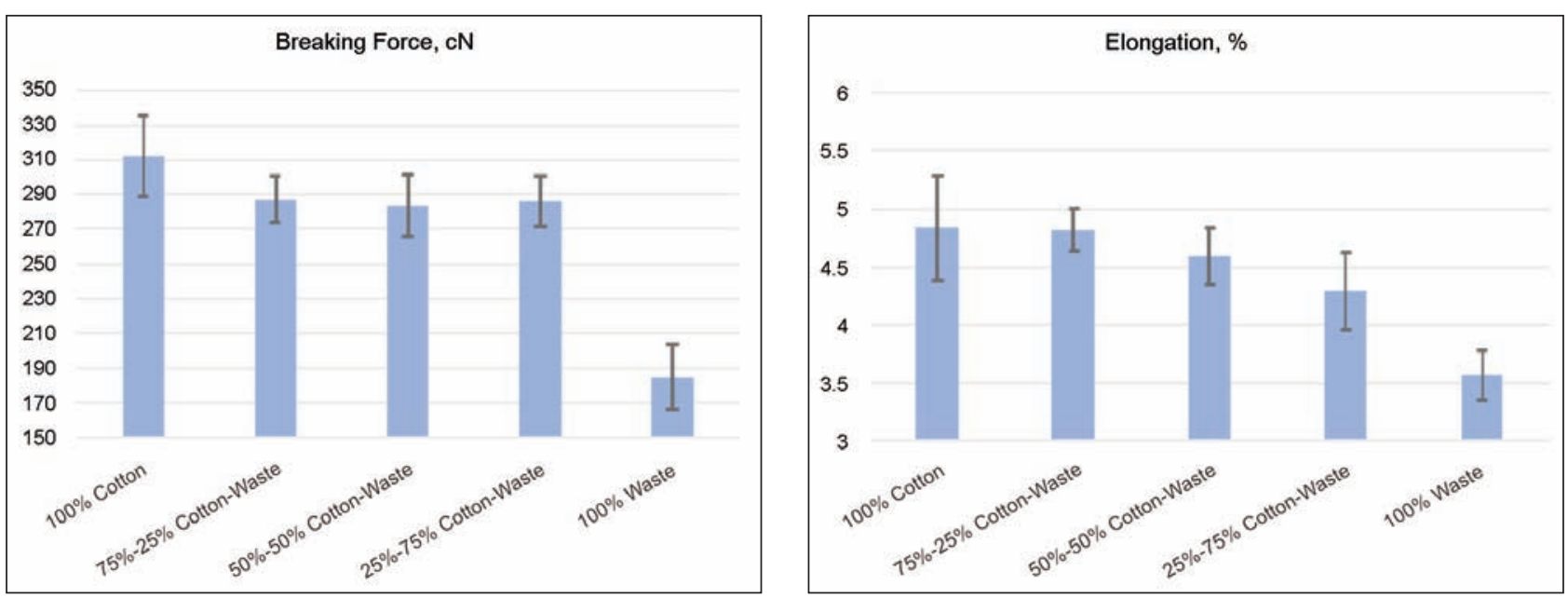

Fig. 4. Breaking force (cN) and breaking elongation (\%) values and 95\% confidence intervals
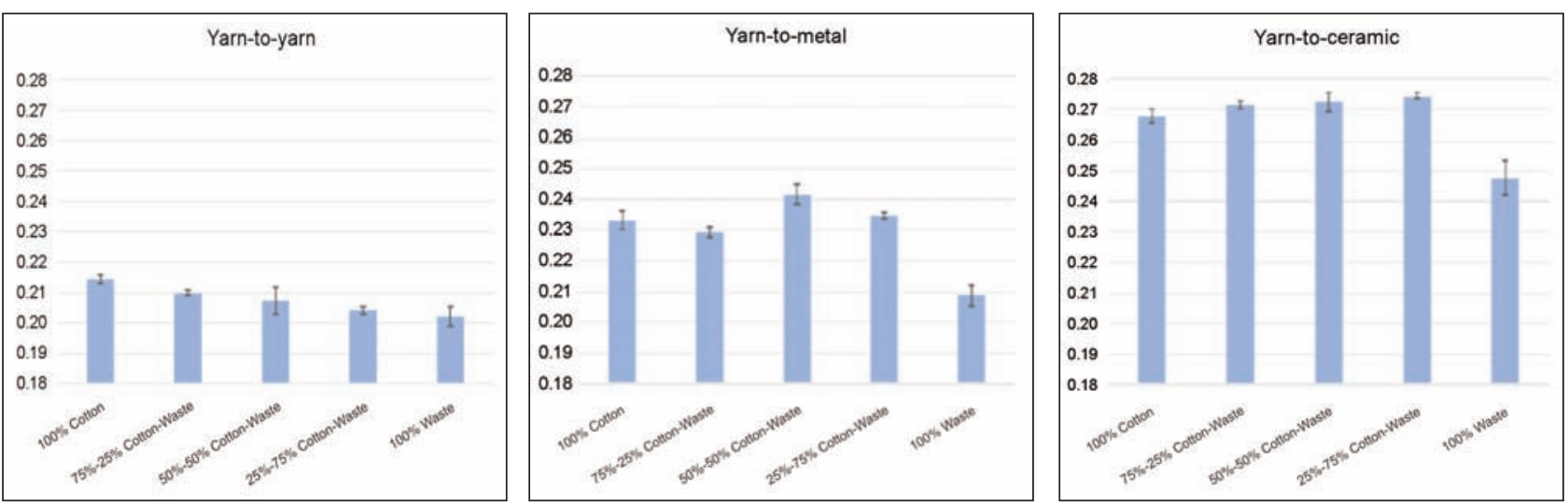

Fig. 5. Friction coefficients and $95 \%$ confidence intervals

related with increasing amount of short fibres create smaller contact surface.

\section{Friction}

Figure 5 shows yarn-to-yarn, yarn-to-metal, yarn-toceramic friction values. The most significant point illustrated by graphs that $100 \%$ waste cotton yarns have the lowest friction values for all surfaces (yarn, metal, ceramic). Friction coefficient is related with yarn hairiness. Because short fibres create a smooth surface, $S 1+2$ values do not cause significant change on friction properties. On the other hand, due to longer fibres might cause stick-slip motion, increasing S3 values give rise to either friction coefficient or output tension.

\section{Evaluation of knitted fabric properties}

\section{Pilling}

Figure 6 illustrates pilling grades of fabrics. Pilling is related with protruding fibre ends, therefore $100 \%$ waste cotton fabrics have the worst pilling values between all fabric types. The other point of view, comparing fabrics produced from blended yarns show that up to $75 \%$ blended ratio does not cause significant change on pilling grade.

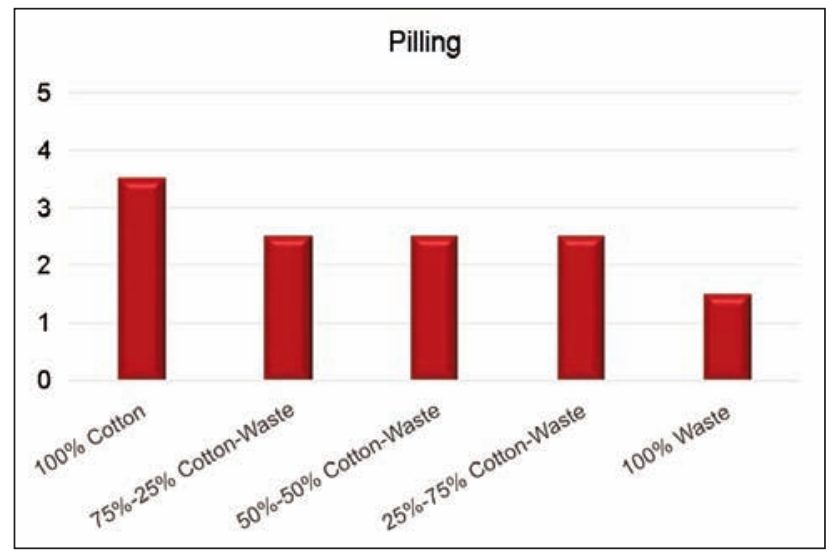

Fig. 6. Pilling ratings

\section{Abrasion resistance}

Figure 7 shows the abrasion resistance results in terms of weight loss (\%) and change in fabric thickness (\%). It can be obtained from the graphs that there is a negative tendency between the waste cotton ratio and abrasion resistance results. However, statistical analysis showed that waste cotton proportion has no significant effect on these values except $100 \%$ waste cotton fabrics. The most probable reason for this situation might be decreasing contact 

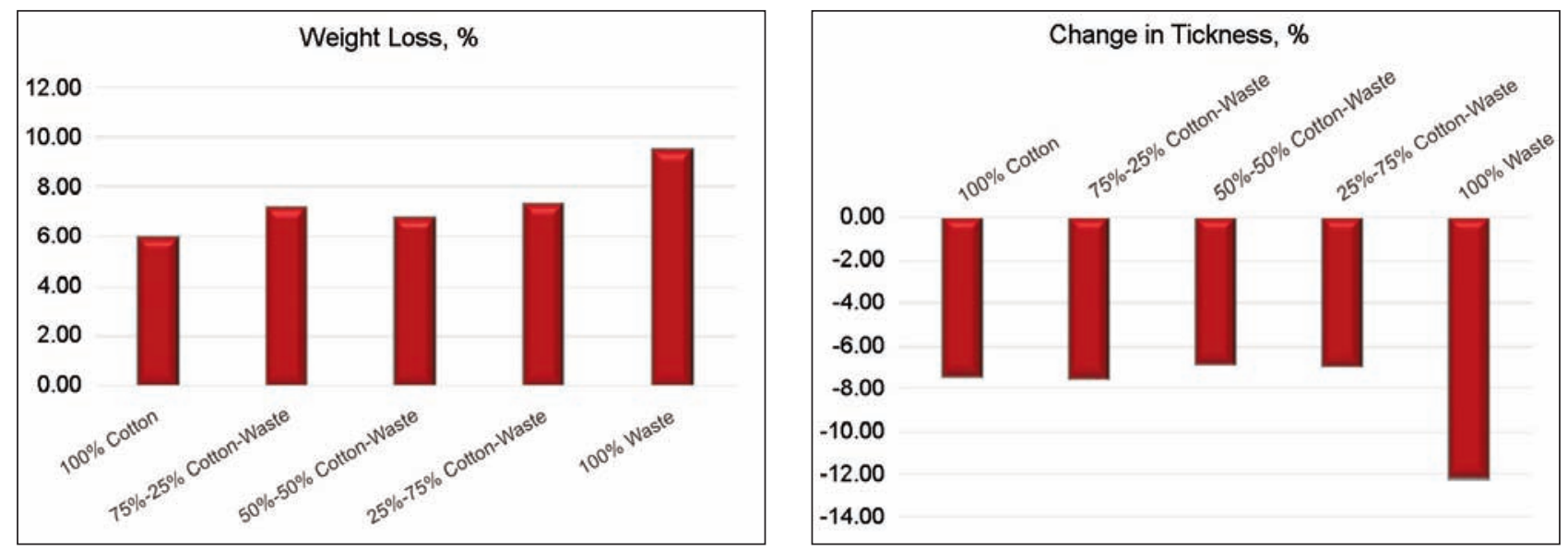

Fig. 7. Weight loss (\%) and change in thickness (\%) after 15000 cycles abrasion test

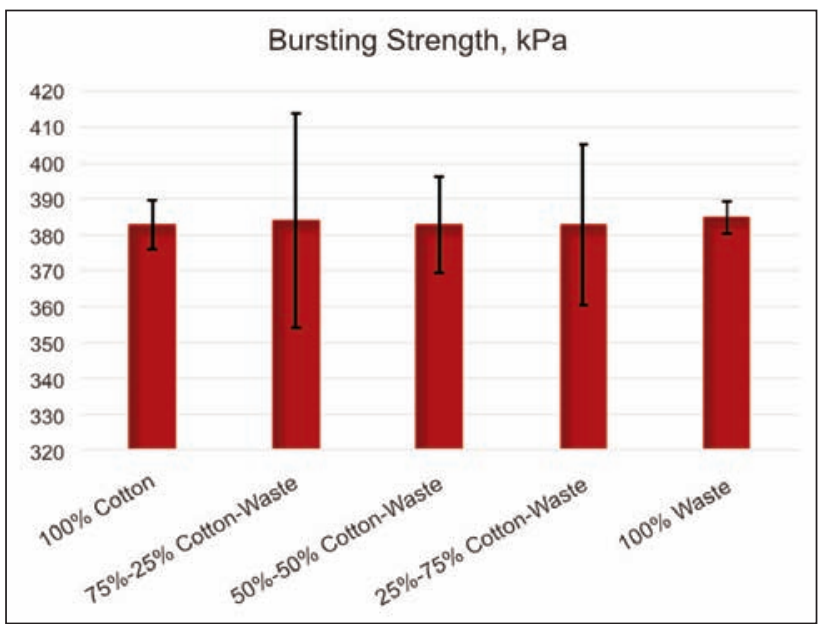

Fig. 8. Bursting strength $(\mathrm{kPa})$ values and $95 \%$ confidence intervals

area between the fibres that causes damage in yarn structure easily after the abrasive movements.

\section{Bursting strength}

Figure 8 illustrates the bursting strength $(\mathrm{kPa})$ results for the fabrics produced from OE-rotor spun blended yarns. Statistical analysis showed that waste cotton proportion has no significant effect on fabric bursting strength.

\section{Air permeability}

Figure 9 shows air permeability values for the produced fabrics. It is clearly seen that air permeability decreases by increasing proportion of waste cotton usage. This situation explained by increasing amount of protruding fibre ends that decrease the fabric porosity.

\section{CONCLUSIONS}

In this study, it was aimed to analyse the effects of cotton waste usage on the properties of yarns and fabrics. For this purpose, OE-rotor yarns made of $100 \%$ virgin cotton, $100 \%$ waste cotton and virgin/waste cotton blends at different proportions (\%25, \%50, \%75) were produced. Moreover, single jersey knitted fabrics were produced from all yarn

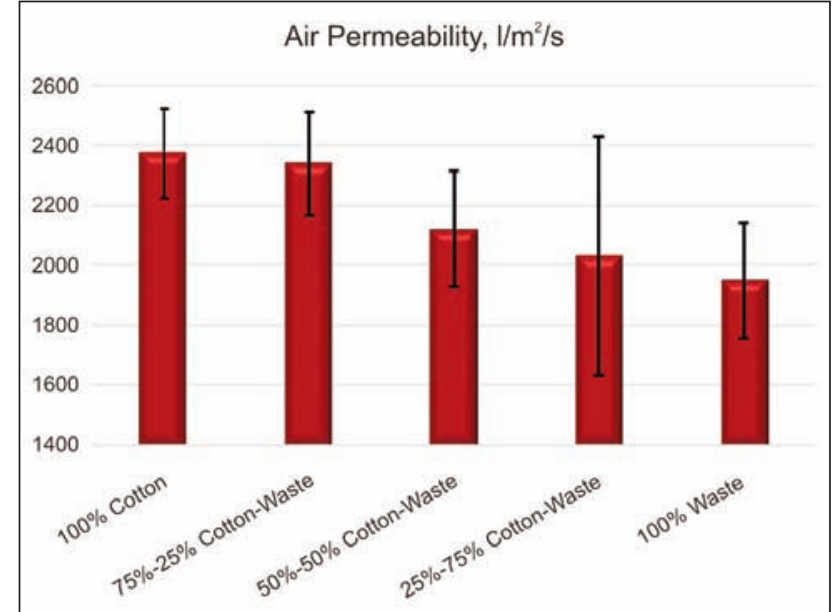

Fig. 9. Air permeability $\left(1 / \mathrm{m}^{2} / \mathrm{s}\right)$ values and $95 \%$ confidence intervals

types. Physical, structural and mechanical properties of all yarn types such as unevenness, imperfections, hairiness, breaking force, elongation, yarn-to-yarn friction, yarn-to-metal friction and yarn-to-ceramic friction were measured. Properties of single jersey knitted fabrics such as pilling, abrasion resistance, bursting strength, air permeability were also evaluated.

Results showed that, as it is expected, yarns and fabrics produced from $100 \%$ virgin cotton have superior results while yarns and fabrics produced from 100\% waste cotton have inferior results in terms of all properties. With respect to the performance properties of yarns and fabrics produced from virgin/waste cotton blends show that using up to $75 \%$ of cotton waste does not cause statistically significant change on the most of yarn and fabric properties. Consequently, it can be concluded that for sustainable, more ecological and economic production process, waste cotton could be used up to $75 \%$ with minor performance reduction of yarn and fabric properties.

\section{ACKNOWLEDGMENT}

This paper was presented in $16^{\text {th }}$ AUTEX, June 8-10, 2016, Ljubljana, SLOVENIA 


\section{BIBLIOGRAPHY}

[1] Wang Y. Recycling in textiles, Woodhead Publishing Limited, Washington, 2006, pp. 1-3.

[2] Shui S., Plastina A. World apparel fiber consumption survey, In: Food and Agriculture Organization of the United Nations and International Cotton Advisory Committee, Washington, 2013, pp. 3-4.

[3] Cotton Incorparated, Cotton Market Fundamentals \& Price Outlook, http://www.cottoninc.com/corporate/MarketData/MonthlyEconomicLetter/, 28.11.2016.

[4] Sule A.D., Bardhan M.K. Recycling of textile waste for environment protection - An overview of some practical cases in the textile industry, In: Indian Journal of Fibre \& Textile Research, 2001, vol. 26, pp. 223-232.

[5] Puma, Puma Recycled Cotton, http://about.puma.com/en/sustainability/products/recycled-cotton, 15.12.2016.

[6] Inditex, Raw Materials, https://www.inditex.com/sustainability/product/raw_material, 02.01.2016.

[7] TNS Political \& Social, Attitudes of Europeans Towards Building the Single Market for Green Products, http://ec.europa.eu/public_opinion/flash/fl_367_sum_en.pdf, 22.01.2013.

[8] Hassani, H., Tabatabaei, S.A., Semnani, D. Determining the optimum spinning conditions to produce the rotor yarns from cotton wastes, In: Industria Textila, 2010, vol. 58, pp. 259-264.

[9] Khan, K.R., Hossain, M.M., Chandra, S.R. Statistical analyses and predicting the properties of cotton/waste blended open-end rotor yarn using Taguchi OA design. In: International Journal of Textile Science, 2015, 4(2), pp. $22-35$.

[10] Taher, H.M., Bechir, A., Mohammed, B.H., Sakli, F. Influence of spinning parameters and recovered fibers from cotton waste on the uniformity and hairiness of rotor spun yarn. In: Journal of Engineered Fibers and Fabrics, 2009, 4(3), pp. 36-45.

[11] Halimi, M.T., Hassen, M.B., Sakli, F. Cotton waste recycling: quantitative and qualitative assessment. In: Resources, Conversation \& Recycling, 2008, vol. 52, pp. 785-791.

[12] Hasssani, H., Tabatabaei, S.A. Optimizing spinning variables to reduce the hairiness of rotor yarns produced from waste fibres collected from the ginning process. In: Fibres \& Textiles in Eastern Europe, 2011, vol. 19, no. 3(86), pp. 21-25.

[13] Halimi, M.T., Hassen, M.B., Azzouz, B., Sakli, F. Effect of cotton waste and spinning parameters on rotor yarn quality. In: The Journal of Textile Institute, 2007, vol. 98, no. 5, pp. 437-442.

[14] Celep, G., Doğan, G., Yüksekkaya, M.E., Tercan, M. An investigation of thermal comfort properties of single jersey fabrics including recycled fibers. In: Düzce University Journal of Science \& Technology, 2015, vol. 4, pp. 104-112.

[15] Vadicherla, T., Saravanan, D. Thermal comfort properties of single jersey fabrics made from recycled polyester and cotton blended yarns, In: Indian Journal of Fibre and Textile Research, 2017, vol. 42, pp. 318-324.

Authors:

MUSA KILIC ${ }^{1}$

H. KÜBRA KAYNAK ${ }^{2}$

GONCA BALCI KILIC ${ }^{1}$

MURAT DEMIR ${ }^{1}$

EFLATUN TIRYAKI ${ }^{2}$

${ }^{1}$ Dokuz Eylül University, Department of Textile Engineering, İzmir, Turkey

${ }^{2}$ Gaziantep University, Department of Textile Engineering, Gaziantep, Turkey

Corresponding author:

MUSA KILIC

e-mail: musa.kilic@deu.edu.tr 


\section{Aspects of the hydrophobic effect sustainability obtained in plasma for cotton fabrics}

DOI: $10.35530 / I T .070 .03 .1475$

\section{REZUMAT - ABSTRACT}

Aspecte ale sustenabilității efectului hidrofob obținut în plasmă pentru țesăturile din bumbac

Această lucrare prezintă mai multe aspecte privind evaluarea ciclului de viață (LCA) pentru țesăturile de bumbac $100 \%$ tratate cu diferite tipuri de compuși ai fluorului utilizând tehnologia cu plasmă RF și tehnologia de fulardare, pentru a obține efectul hidrofob. Pentru a evidenția efectele obținute prin tehnologia cu plasmă RF (radiofrecvența) s-a efectuat în paralel un studiu privind efectul hidrofob obținut utilizând o dispersie de compuși de fluor (NUVA TTC) pe fulard. Concluziile studiului au fost că, dacă se utilizează tratamentul cu plasmă pentru efectul hidrofob, atunci acest lucru ar influența negativ mediul prin încălzirea generată de gaze și consumul de energie, atunci când se utilizează metoda de fulardare și substanțele chimice deja stabilite, impactul ar consta în creșterea consumului de combustibili fosili, substanțe anorganice respiratorii și schimbări climatice. A fost analizat inventarul ciclului de viață (LCI) și evaluarea ciclului de viață (LCA) folosind software-ul SimaPro și Eco-indicator 99. Pentru obținerea LCl, au fost utilizate datele tehnice de intrare și ieșire din procesul de plasmă/fulard și software-ul SimaPro pentru a genera LCA pe baza acestor date. Datele de intrare despre materia primă, energie, substanțele chimice au fost colectate prin măsurători directe pe echipamente, manuale de utilizare ale dispozitivelor și specificații ale echipamentelor (cărți tehnice) și procese. Datele de ieșire (energia reziduală și substanțele chimice) au fost obținute utilizând statistici, baze de date de pe internet și software-ul SimaPro. Obiectivul inițiativei noastre științifice a fost studierea sustenabilității tehnologiei cu plasmă RF utilizate pentru hidrofobizare și s-a dovedit că tehnologia cu plasmă utilizată pentru efectul hidrofob este mai puțin ecologică decât tehnologia de fulardare pentru o unitate funcțională de $1 \mathrm{~kg}$ de material tratat.

Cuvinte-cheie: textil, plasma RF, hidrofobizare, LCA, LCI, mediu

\section{Aspects of the hydrophobic effect sustainability obtained in plasma for cotton fabrics}

This paper presents several aspects concerning the life cycle assessment (LCA) for $100 \%$ cotton fabric treated with different types of Fluor compounds using RF plasma technology and foulard technology, in order to obtain the hydrophobic effect. To highlight the effects obtained by RF (radio frequency) plasma technology was conducted in parallel a study about hydrophobic effect obtained using a dispersion of fluorine compound (NUVA TTC) on foulard. The conclusions of the study were that if we use the plasma treatment for hydrophobic effect then this would influence the environment negatively by warming generated by gases and power consumption, when using the foulard method and chemical substances already established, the impact would consist of increasing the consumption of fossil flues, respiratory inorganics, and climate change. We analyzed the life-cycle inventory (LCI) and life-cycle assessment (LCA) using SimaPro software and Eco-indicator 99. For obtaining the $\mathrm{LCl}$, we used to input and output technical data, from the plasma / foulard process, and the SimaPro software for generating the LCA based on these data. The input data about raw material, energy, chemical substances, have been collected by direct measurements on machinery, device logs and specifications of the equipment (technical books) and processes. The output data (waste energy and chemicals) were obtained using statistics, internet databases, and SimaPro software. The objective of our scientific initiative has been to study the sustainability of the RF plasma technology used for hydrophobization, and we obtained that plasma technology used for hydrophobic effect is less eco-friendly than foulard technology for a functional unit of $1 \mathrm{~kg}$ treated material.

Keywords: textile, RF plasma, hydrophobization, LCA, LCl, environment

\section{INTRODUCTION}

The environmental impact categories identified (carcinogenic, inorganic compounds upon the breath, climate change, radiation, ozone layer, eco-toxicity, land use, minerals, and fossil fuels) have been obtained by using the method ECO indicator 99. In order to obtain the life-cycle assessment (LCA) [1], it is necessary to analyze the life-cycle inventory ( $\mathrm{LCl}$ ) for hydrophobic textiles obtained by standard technology (foulard method) and by advanced technology
(RF plasma [2, 3]). Moreover, it is necessary to collect inputs and outputs for the duration of the life cycle of the (figure 1), for both treatments carried out using fluorine compounds such as NUVA TTC, sulfur hexafluoride, and Teflon. The inputs and outputs requested for ICV and LCA are:

1. Inputs:

- Raw materials;

- Energy used;

- The water used; 


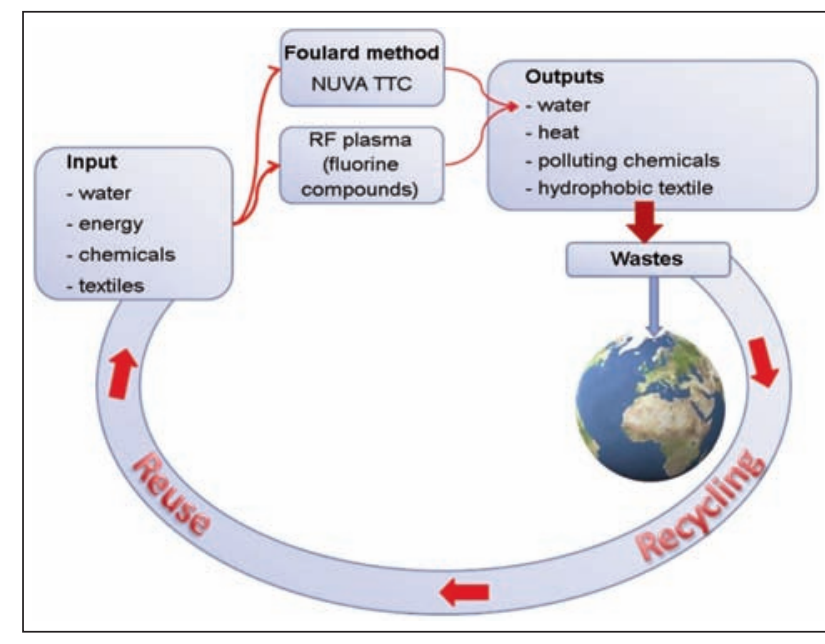

Fig. 1. Input/Output - foulard and plasma technologies

- The main ratio between the hydrophobic product and co-products;

- The rate of production.

2. Outputs:

- The waste discharged into the ambient environment.

For evaluating life-cycle as compared, within the framework of this phase, data were collected from both technological processes of RF plasma and foulard method, directly, indirectly by sources available on the internet (specific databases) and literature on the subject [4-7].

ECO-Indicator Method 99 provides quantification of the impact for environmental processes by categories of impact: carcinogenic substances results, harmful organic and inorganic substance through breathing, climatic changes caused by the substances with the greenhouse effect, radiation, changes that take place at the level of the ozone layer, ecotoxicity, acidification/Eutrophication, land use, minerals and consume fossil fuels for power generation.

For the assessment of environmental impact, by SimaPro7, have been used methods of normalization, weighting, single score and "damage assessment" (assessment of the extent of damage) [8, 9].

- The normalization method shows the extent to which a category of impact has a significant influence on the environment.

- The weighting method has as its objective reporting to the category of impact on the relative importance of it.

- The single score method involves the specification of the multiplication of substances, which contribute to the impact, with a factor of specification expressing the relative contribution of the substance.

- The method of assessing the degree of damage "damage assessment" aims the combination of some categories of impact in order to obtain a category of damage, also called the protection zone.

\section{EXPERIMENTAL PART}

The experimental part consisted of the development of the LCA comparative assessments studies for hydrophobic materials obtained. Data were collected from the industrial, technological process and secondary sources such as internet database and specialty scientific literature and were used to establishing the LCA [7-8]. The input data for LCI and LCA are presented in table 1 for the hydrophobization process using plasma equipment, respective for classical hydrophobization process using foulard equipment.

\begin{tabular}{|c|c|c|}
\hline \multicolumn{3}{|c|}{ INPUT DATA FOR HYDROPHOBIZATION USING PLASMA PROCESS USING PLASMA } \\
\hline Data about the industrial process & U.M. & Value \\
\hline \multicolumn{3}{|l|}{ 1. Data about fabric consumption } \\
\hline Fibrous composition & \multicolumn{2}{|l|}{$100 \%$ cotton } \\
\hline Width & $\mathrm{cm}$ & 150 \\
\hline \multirow{2}{*}{ Mass } & $\mathrm{g} / \mathrm{m}^{2}$ & 401 \\
\hline & $\mathrm{g} / \mathrm{ml}$ & 602 \\
\hline Mass (the fabric used in the industrial process) & $\mathrm{kg}$ & 100 \\
\hline \multicolumn{3}{|c|}{ 2. Data about plasma equipment (energy and chemicals consumptions) } \\
\hline Plasma equipment & W & 1215 \\
\hline \multicolumn{3}{|l|}{ 2.1 Data about chemicals substances consumption } \\
\hline Argon gas & $\mathrm{cm}^{3}$ & 800 \\
\hline Fluorine compounds & $\mathrm{kg} / 100 \mathrm{~kg}$ fabric & 21.14 \\
\hline 2.2 Process duration & $\min$ & 10 \\
\hline \multicolumn{3}{|l|}{ 3. Data about foulard equipment consumptions } \\
\hline 3.1 Water for treatment solution & L water/100 kg fabric & 74 \\
\hline 3.2 NUVA TTC & $\mathrm{kg} / 100 \mathrm{~kg}$ fabric & 5.6 \\
\hline 3.3 Methane gas & $\mathrm{m}^{3}$ & 90 \\
\hline 3.4 Electrical energy & $\mathrm{kW}$ & 95 \\
\hline 3.5 Process duration & $\min$ & 108 \\
\hline
\end{tabular}


SimaPro7 can evaluate the impact on the environment through the following approaches: normalization, characterization, weighting, damage assessment and Single Score [9-11].

The normalization is a procedure required to show the extent to which a category of impact has a significant contribution to the general problem of the environment, and is done using the division of the category indicator of impact by a value of "Normal" [12-14].

The weighting method has as its objective the quantitative aggregation of the results of using the weighting factors. This kind of approach has an impact on categories reported between these categories. Each category of impact is multiplied by weight [14-15].

The characterization method consists in the multiplication of all impact categories by a factor which reflects the relative contribution to the environmental impact, quantifying how much impact has the hydrophobic textile obtained by foulard and by RF plasma in each impact category.

The single score method is based on weighting method and is presented the impact on each input of the system.

The damage-assessment method uses different procedures to establish the relationship between the inputs and the potential damages. For example, the damage analysis in the model for human health impact links health effects to the number of Years Lived Disabled (YLD) and Years of Life Lost (YLL) [16].

The impact types obtained by SimaPro are presented in the following diagrams:

- LCA comparative assessment using method for the evaluation of damage (figure 2);

- LCA comparative assessment using the normalization method (figure 3);
- LCA comparative assessment using characterization method (figure 4);

- LCA comparative assessment using the weighting method (figure 5);

- LCA comparative assessment using Single Score method (figure 6).

In figure 2 is presented the damage assessment of the process that involves RF plasma, and fluorine compounds have a $100 \%$ impact on all categories. The classical treatment based on the foulard method and NUVA TTC has a lower impact, the higher values being for fossil fuels consumption (10\%), ecotoxicity $(6 \%)$, harmful organic chemicals by respiration $(6 \%)$, chemicals with carcinogenic effect $(4 \%)$, ocean acidification by $\mathrm{CO}_{2}$ emissions into atmosphere (4\%) and harmful inorganic chemicals by respiration (3\%).

In figure 3 is presented the normalization diagram and is visible that RF plasma treatments have a $100 \%$ impact on environment generating climate changes due to the emissions in the atmosphere. Also, the impact on electrical energy consumption generates an impact on fossil fuels consumption. From figure 3 can be observed a minor impact or even zero by respiratory organics, radiation, land use and ecotoxicity as a consequence of the plasma technology because low-pressure plasma technology does not generate organics vapors emissions, heat, and wastewater.

In figure 4 is presented the characterization diagram and is evident that for all categories the RF plasma technology has an impact of $100 \%$, while the impact of the classical technologies has values lower the $10 \%$, such as for fossil fuels consumption the impact is $9.5 \%$, for ecotoxicity and harmful organic chemicals by respiration the impact approximated to $6 \%$. In figure 6 is presented the Single Score diagram for comparative LCA RF plasma vs. foulard method, and

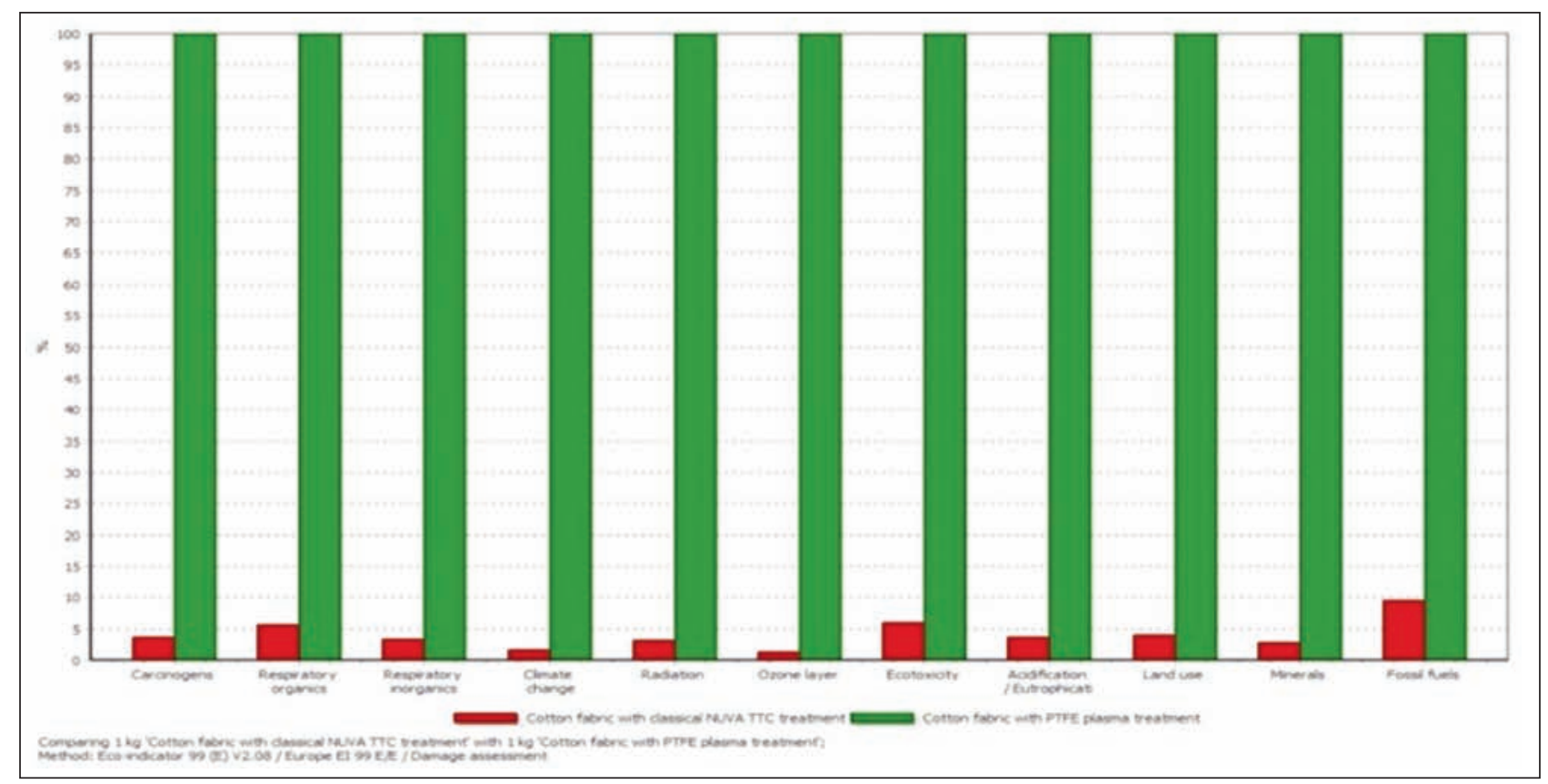

Fig. 2. The histogram of the comparative assessment of the impact of the life cycle for hydrophobic cotton fabric obtained by foulard with NUVA TTC and by RF plasma (Teflon), using the method for the evaluation of damage 


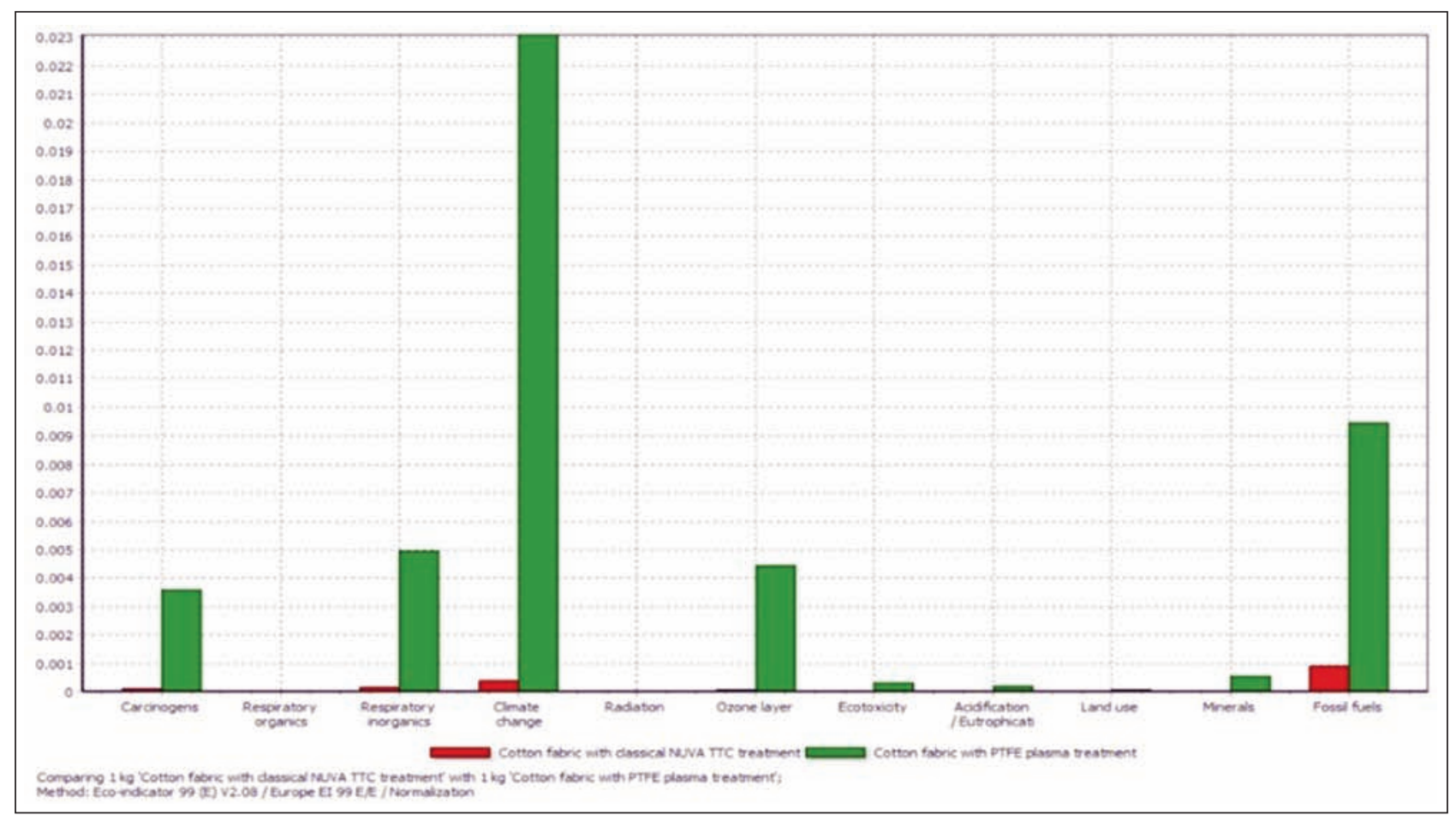

Fig. 3. The histogram of the LCA comparative assessment for hydrophobic cotton fabric obtained by foulard with NUVA TTC and by RF plasma (Teflon), using the normalization method

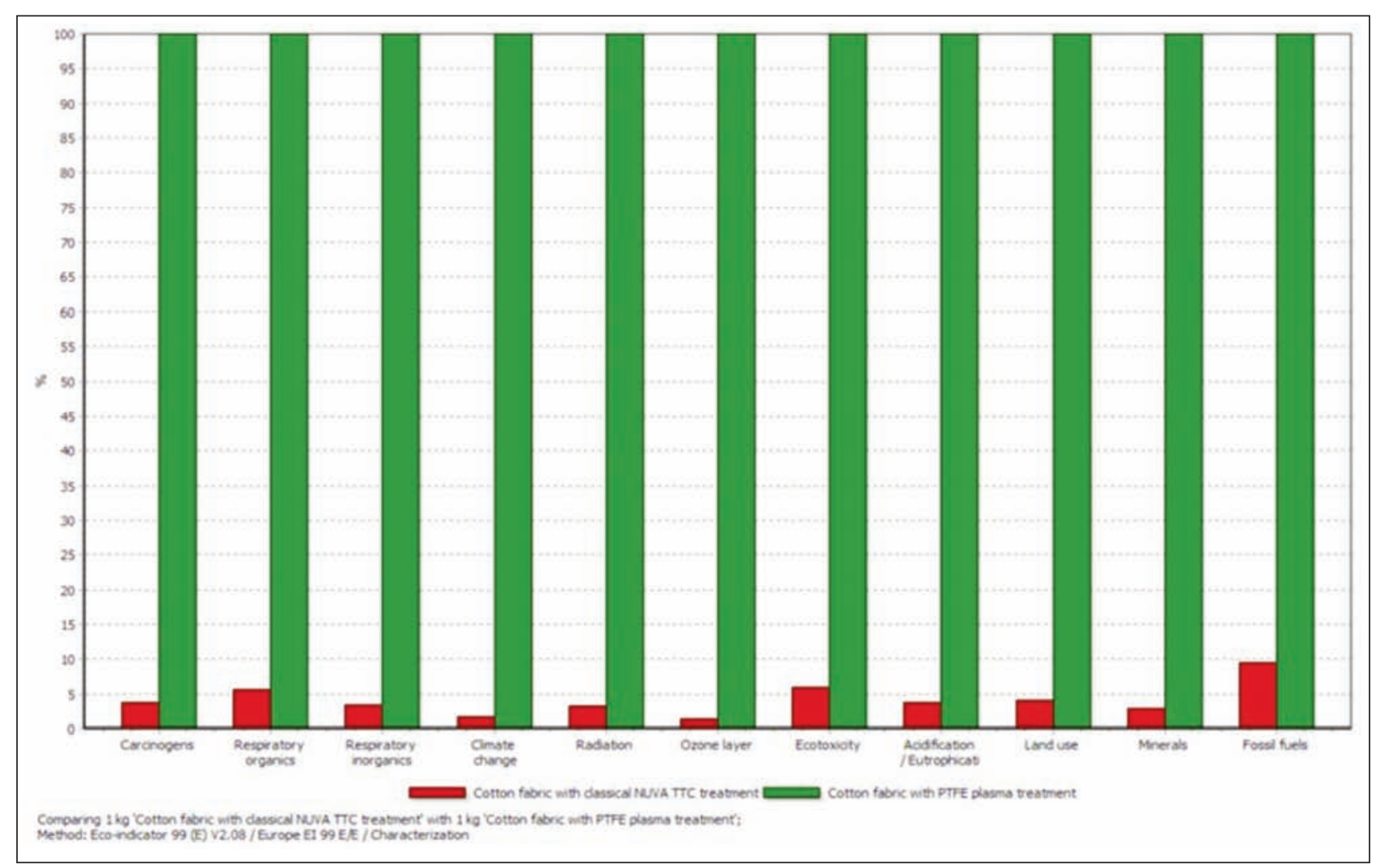

Fig. 4. The histogram of the LCA comparative assessment for hydrophobic cotton fabric obtained by foulard with NUVA TTC and by RF plasma (Teflon), using the characterization method

is evident that RF plasma technology based on fluorine compounds has a significant impact in comparison with standard treatment based on NUVA TTC. The advanced RF plasma treatments have a considerable influence on climate change due to the emissions with the greenhouse effect. Also, plasma tech- nology has a medium impact on fossil fuel consumption, on the ozone layer, by inorganics chemicals harmful for respiration and carcinogenic effect.

In figure 5 is presented comparative life cycle assessment based on weighting diagram and can be observed that RF plasma technology has a significant 


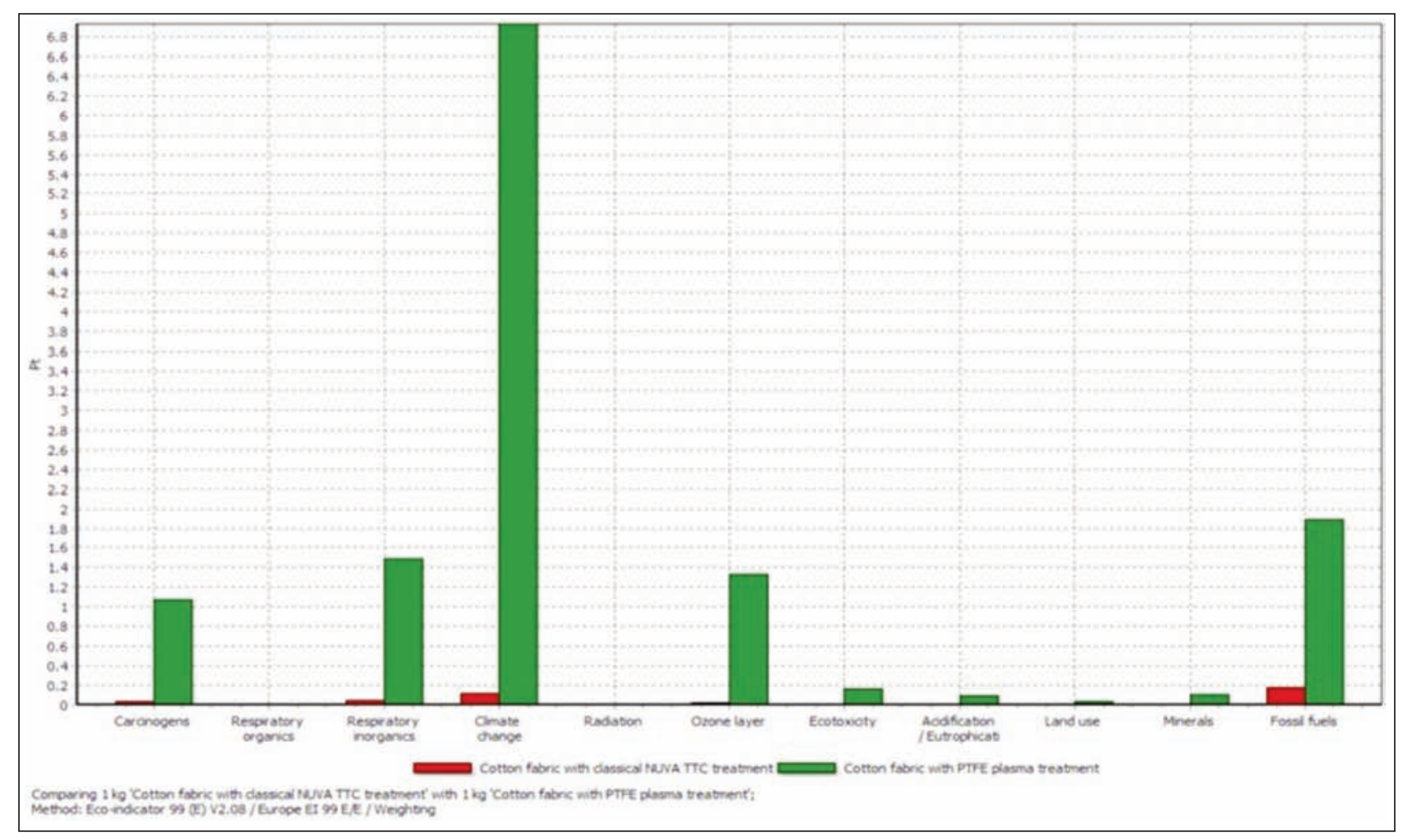

Fig. 5. The histogram of the LCA comparative assessment for hydrophobic cotton fabric obtained by foulard with NUVA TTC and by RF plasma (Teflon), using the weighting method

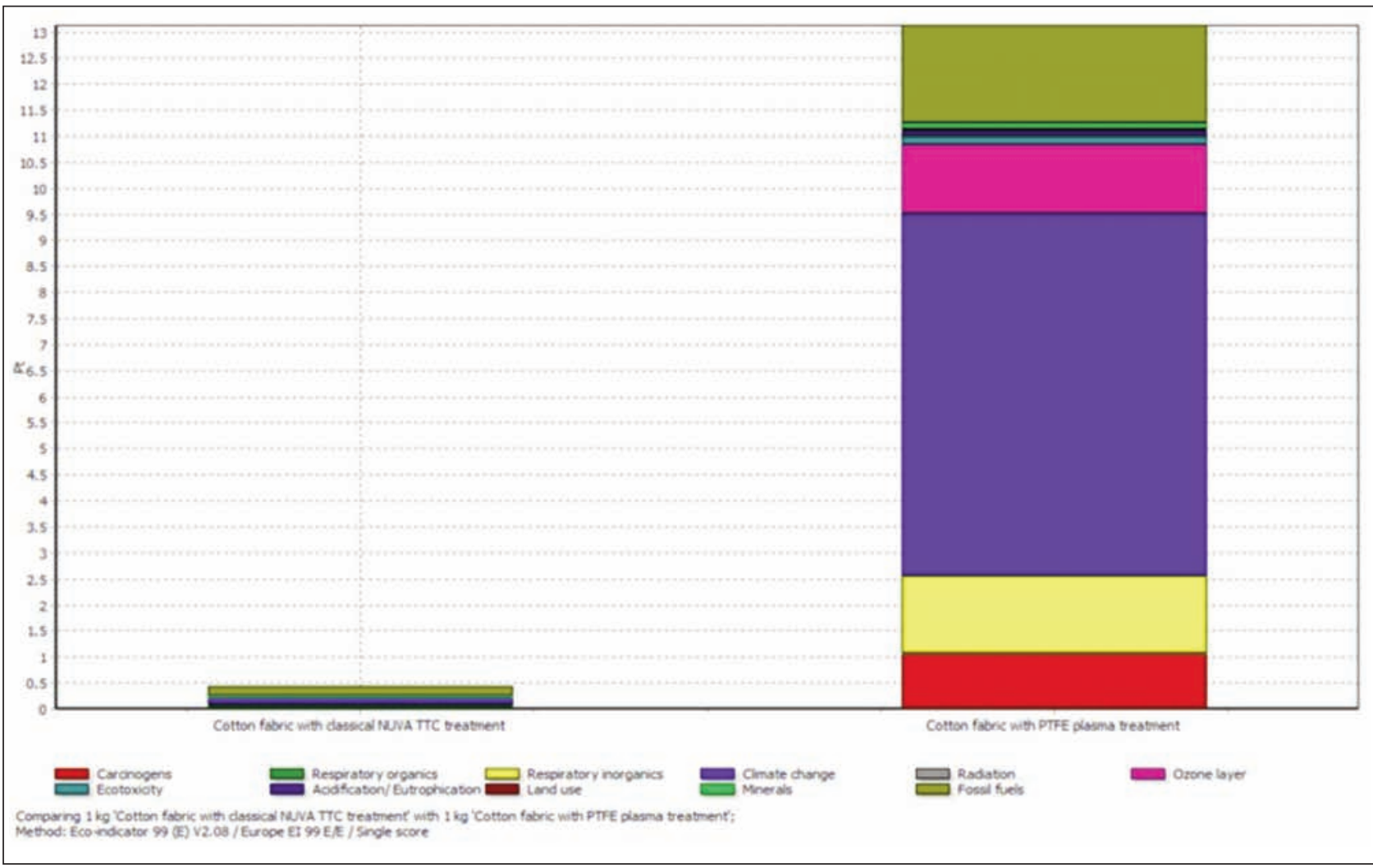

Fig. 6. The histogram of the LCA comparative assessment for hydrophobic cotton fabric obtained by foulard with NUVA TTC and by RF plasma (Teflon), using the Single Score method

impact on climate changes and small impact by inorganic chemical harmful by respiration, by reducing the ozone layer and by consumption of fossil fuels necessary for generating the electrical energy.

\section{CONCLUSIONS}

The investigation of the process and the diagram for environmental impact on different categories (EcoIndicator Method 99) [17-18] were prepared by 
weighting method, characterization, damage assessment, weighting, and normalization method. From all diagrams used in evaluation, we observed a significant impact of the classic hydrophobization (NUVA TTC) on fossil fuels, ecotoxicity by number of effects as acute and chronic toxicity on different species in water, harmful organic chemicals by respiration, chemicals with carcinogenic effect, ocean acidification by $\mathrm{CO}_{2}$ emissions into the atmosphere and harmful inorganic chemicals by respiration. Besides, RF plasma Teflon treatments have a significant impact on climate change, on the ozone layer, by inorganics chemicals harmful for respiration and carcinogenic effect. However, unlike traditional hydrophobization treatment, RF plasma technology low pressure used to obtain hydrophobic textile does not generate organics vapors, heat, and wastewater. The economy of the chemicals (fluorine compounds) gives the sustainability of the hydrophobization by RF plasma because the surface cleaning and hydrophobization are simultaneous. The typical hydrophobization process based on the foulard method generates toxical vapor, heat, and wastewater, while RF plasma does not generate wastewater generate some harmful emission discharged in the atmosphere. In comparison with the traditional process, the technology RF plasma is more expensive as device and maintenance, and request high qualified engineers.

\section{ACKNOWLEDGMENTS}

The research presented in this paper was prepared in the INCDTP laboratories. Funds support this work from ANCSI, National Project "The assessment of the life cycle of the hydrophobic textile materials", Contract PN 16340407.

\section{BIBLIOGRAPHY}

[1] Surdu, L., Radulescu, I.R. and Barbu, I. Life cycle assessment for medical textiles treated with plasma, In: Industria Textila, 2015, 66(6), pp. 360-364.

[2] Rauscher, H., Perucca, M. and Buyle, G. eds. Plasma technology for hyperfunctional surfaces: food, biomedical and textile applications, John Wiley \& Sons, 2010.

[3] Surdu, L., Surdu, I., and Radulescu, I.R. Research for accomplishing multifunctional textiles with plasma technology, In: Industria Textila, 2016, 67(5), p. 314.

[4] Nieminen, E., Linke, M., Tobler, M. and Vander Beke, B. EU COST Action 628: life cycle assessment (LCA) of textile products, eco-efficiency and definition of best available technology (BAT) of textile processing, In: Journal of Cleaner Production, 2007, 15(13-14), pp. 1259-1270.

[5] Aileni, R.M., Surdu, L., and Oksuz, L., May. Life cycle and environment impact for textile materials functionalized by using plasma technology, In: 2015 IEEE International Conference on Plasma Sciences (ICOPS), 2015, pp. 1-1, IEEE.

[6] Kiekens, P., Van der Burght, E., Kny, E., Uyar, T. and Milašius, R. Functional textiles - from research and development to innovations and industrial uptake, In: Autex Research Journal, 2014, 14(4), pp. 219-225.

[7] Bonaldi, R.R. Functional finishes for high-performance apparel, In: High-Performance Apparel, 2018, pp. 129-156, Woodhead Publishing.

[8] Miseljic, M. and Olsen, S.I. Life-cycle assessment of engineered nanomaterial: a literature review of assessment status, In: Journal of nanoparticle research, 2014, 16(6), p. 2427

[9] Curran M. A. Life Cycle Assessment Handbook, Wiley Publishing, USA, 2012.

[10] https://www.pre-sustainability.com/weighting-applying-a-value-judgement-to-lca-results.

[11] https://www.lokad.com/product-life-cycle-(inventory-planning).

[12] Sanfwon, Suh, Gjalt, Huppes, Methods for Life Cycle Inventory of a product, In: Journal of Cleaner Production, Vol. 13, Issue 7, pp. 687-697, 2005.

[13] Werner F., Ambiguities in decision-oriented life cycle inventories, Springer, 2005.

[14] Steward, M. and Weidema, B. A consistent framework for assessing the impacts of resource use. A focus on resource functionality, In: Int. J. Life Cycle Assess, 10 (4), pp. 240-247, 2004.

[15] Suh, S. Input-output and hybrid life cycle assessment, Int. J. Life Cycle Assess, 8 (5), p. 257, 2003.

[16] Herrera, I., Kulay, L., Jiménez, L. and Schuhmacher, M. Environmental Damage Assessment Applied to Process Analysis. A Decision Support Alternative, In: $1^{\text {st }}$ International Congress on Environmental Modelling and Software - Lugano, Switzerland, 2002.

[17] http://www.ecoinvent.org/

[18] Aileni, R. M., Dinca, L., Surdu, L. Textile surface hydrophobization by using plasma nanotechnology, In: Annals of the Academy of Romanian Scientists, Series on Science and Technology of Information, vol. 7, issue 2, pp. 43-48, 2014.

\section{Authors:}

RALUCA MARIA AILENI, LAURA CHIRIAC, ADRIANA SUBTIRICA, SILVIA ALBICI, LAURENTIU CRISTIAN DINCA

National Research \& Development Institute for Textiles and Leather, Lucretiu Patrascanu no.16, 030508 Bucharest, Romania

\section{Corresponding authors:}

RALUCA MARIA AILENI

e-mail: raluca.aileni@certex.ro 


\section{Preparation of PDO mesh and research on its fabrication parameters}

DOI: 10.35530/IT.070.03.1544

\section{Prepararea plasei PDO și studio privind parametrii de fabricare}

Folosirea protezelor pentru înlocuirea țesuturilor slăbite sau a fasciei pelvine este acceptată de mai mulți specialiști din domeniul medicinii actuale. PDO este, de asemenea, considerat un material degradabil ideal, cum ar fi PP, care a fost cel mai popular poplimer utilizat în domeniul medical. Studiul a pregătit o plasă PDO cu structură macroporoasă utilizând un model de placă armată cu structură poroasă de formă pătrată și materii prime din monofilamente PDO. Parametrii de fabricare, inclusiv diametrul monofilamentului, dimensiunea porilor, forma porilor, au fost analizate pe baza proprietăților mecanice adecvate ale plaselor PDO. Procesele optime de fabricație au fost obținute ulterior. Rezultatele au arătat că monofilamentele PDO cu diametrul de 0,23 mm ar putea face ca plasa să aibă propria greutate, grosime și rezistență la tracțiune, precum și cea mai mare forța de scoatere a suturii. Forma pătrată a porilor a întărit forța de tracțiune a plasei, menținând o forță mai mare de scoatere a suturii, în special în comparație cu forma de romb a porilor. În ceea ce privește dimensiunea porilor, plasa PDO cu pori de $5 \mathrm{~mm}$ a avut o rezistență mai mare, satisfăcând, de asemenea, necesitatea de greutate redusă a plasei. Degradarea in vitro a plasei PDO a fost măsurată folosind 3 monofilamente cu diametru diferit. Toate probele au fost degradate semnificativ numai după 10 săptămâni, rata de pierdere în greutate atingând aproximativ $30 \%$ după 16 săptămâni. În final, plasa PDO a fost evaluată pentru a avea un avantaj clar al greutății reduse, dar un risc scăzut de rezistență în comparație cu diverse alte tipuri de plasă comercializate.

Cuvinte-cheie: plasă medicală, PDO, parametrii de fabricare, proprități mecanice

\section{Preparation of PDO mesh and research on its fabrication parameters}

Using prosthesis to replace weaken tissues or fascia in pelvic is accepted by more people in present medicine field. PDO is also considered to be an ideal degradable material such as PP, which was the most popular used type in medical area. The paper prepared macro-porous structure PDO meshes using an armor plate model of square-pore structure and raw material of PDO monofilaments. Fabrication parameters including monofilament diameter, pore size, pore shape were discussed based on a suitable mechanical properties of PDO meshes. The optimal fabrication processes were obtained after then. The results revealed that PDO monofilaments of $0.23 \mathrm{~mm}$ diameter could make mesh to own moderate weight, thickness and tensile strength, as well as the largest suture pulling out force. Square-pore shape strengthened mesh tensile force, maintaining larger suture pulling out force especially compared to that of rhombus-pore shape. As for pore size, PDO mesh with $5 \mathrm{~mm}$ pores had larger strength, also satisfying requirement of mesh's lightweight. In vitro degradation of PDO mesh was measured using 3 different diameter monofilaments. All samples were significantly degraded only after 10 weeks, with weight loss rate reaching to about $30 \%$ after 16 weeks. Finally, PDO mesh was assessed to have an obvious lightweight advantage, but low strength risk by comparison to several commercial mesh products.

Keywords: medical mesh, PDO, fabrication parameter, mechanical property

\section{INTRODUCTION}

Pelvic floor dysfunction (PFD) covers diseases of pelvic organ prolapse and stress incontinence, with symptoms like metroptosis, vaginal wall bulge, defecation disorder. With the aging trend of the population in the world, senile diseases such as POP and SUI have a much higher morbidity. More than 50\% women over 50 years old are suffering from the diseases, with lifetime risk reaching to $30 \%$ to $50 \%$. PFD has a serious health risk to women, more than $11 \%$ of them even need to receive operation. Traditional surgery focused on repeatedly reinforced weak tissues, difficult to build a stable pelvic floor to resist the change of pressure. However, implanting mesh in pelvic area no more than repairs, but also brings weaken tissues to regeneration, reconstruct the whole pelvic floor and recover its anatomical structure.

With more advanced materials' wide clinical applications, reconstruction and repair of pelvic floor was improved greatly in recent years. Among various medical meshes, polypropylene (PP) is the most widely used type for its nice mechanical property and biocompatibility. PP material can be designed to several structures, leave a big part for product renewal. Also, it has good chemical stability which can live through the complex human internal environment. However, some defects of PP mesh such as hard hand-feeling and non-degradability, resulted in serious foreign body sensation, tissue adhesion and 
chronic infection [1, 2]. Moreover, PP mesh permanently existing in human body may immigrate into bladder after implantation longer than 5 years, lead to complications also. Recent research indicates that mesh is developing along a direction of lightweight, minimally invasive and being absorbable. In view of the high strength and degradability of Polydioxanone (PDO), the mesh is assumed to have advantages of light weight, low thickness, effectively reducing tissue adhesion and foreign body sensation [3-5]. The PDO material is not applied in medical mesh, but in other biomedical area. For example, Junyao Cai et al. prepared a mesh-structure stent reinforcement by hand braiding method, it is proved to have large porosity and good tensile property [6]. The high porosity is definitely an important character for improving mesh's application effect [7, 8].

This paper adopted 3 different diameter PDO monofilaments, braided to several mesh samples with different pore shape and pore size. The fabrication parameters were optimized based on measurements of tensile strength, bursting strength, bending stiffness and in vitro degradation property. The new type PDO mesh was also comprehensive evaluated by comparison to several commercial products, provided an experimental foundation for future study.

\section{EXPERIMENTAL WORK}

\section{Materials}

PDO monofilaments used for mesh preparation were provided by META BIOMED CO. LTD (Korea). The tensile property of monofilament was tested by YG(B)026G-500 electronic strength tester (Darong Textile Instruments Factory Co., Ltd, China) according to standard GB/T3923.1. The gauge between sample and chuck was $20 \mathrm{~mm}$, draw speed was 40 $\mathrm{mm} / \mathrm{min}$. The tensile property of PDO monofilaments was represented by breaking strength (cN/dtex) and elongation rate (\%).

The bending stiffness was measured by KES-FB2 ((KATO TECH, Japan). Twenty PDO monofilaments were parallel stuck to paperboard with grooves (figure 1). The samples were clamped between testing holder, drawn to curve in two directions with curvature from -2.5 to 2.5 . The bending stiffness $\left(\mathrm{N} \cdot \mathrm{mm}^{2}\right)$ of PDO monofilaments was obtained by sensor.

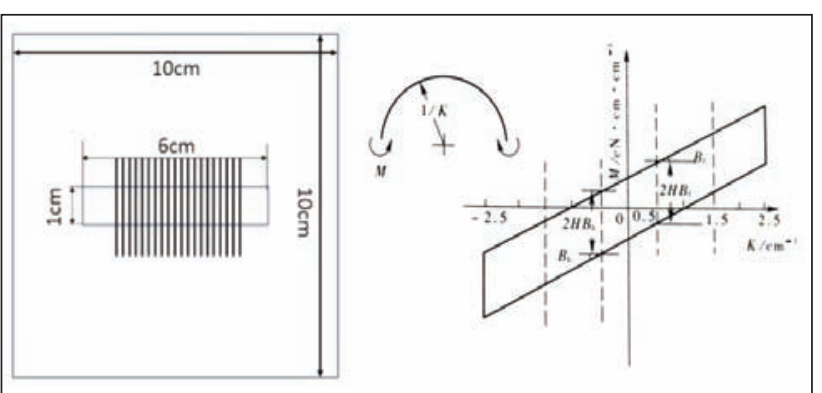

Fig. 1. Testing method (left) and principle (right) of bending stiffness

\section{Preparation of PDO mesh}

The PDO meshes were hand-braided using an armor plate model. PDO monofilaments run lengthwise and crossed at right angle to weft yarns. The weaving points were bond using medical adhesive bandage (Loctite, United States). The size of plate model was $15 \mathrm{~cm} \times 15 \mathrm{~cm}$ with grooves of $5 \mathrm{~mm} \times 5 \mathrm{~mm}$. Three types of PDO monofilaments $(0.16 \mathrm{~mm}, 0.23 \mathrm{~mm}$, $0.29 \mathrm{~mm}$ ) were adopted to prepare meshes with square-pore shape, designed into pore size of $5 \mathrm{~mm}$ and $10 \mathrm{~mm}$, respectively. The design structure of square-pore mesh was showed in figure 2 .

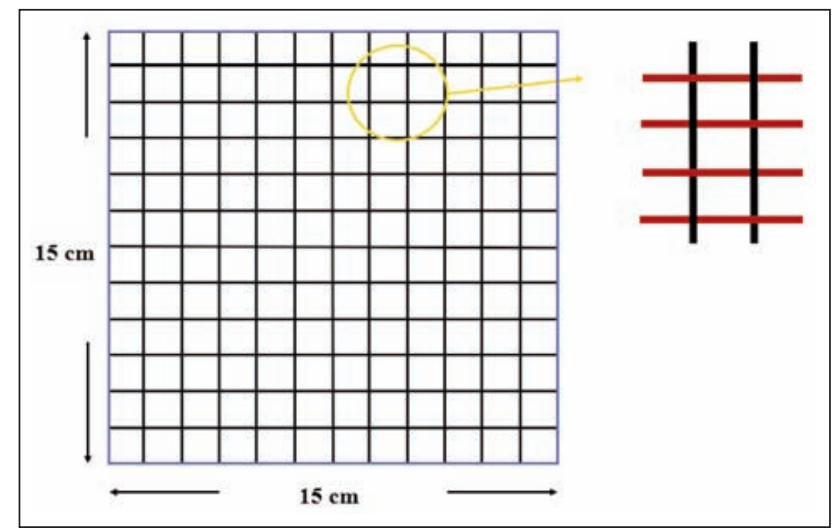

Fig. 2. Design Structure of square-pore PDO mesh

Then rotated plate mode was 45 degree, using the 3 types of PDO monofilaments to prepare rhombuspore PDO mesh, also under size of $5 \mathrm{~mm}$ and $10 \mathrm{~mm}$, respectively. The design structure of rhombus-pore PDO mesh was shown in figure 3 .

The braided mesh was heat-setting to obtain a permanent shape under temperature of $85^{\circ} \mathrm{C}$, time of

Table 1

\begin{tabular}{|c|c|c|c|c|c|}
\hline \multicolumn{5}{|c|}{ SPECIFICATION AND MECHANICAL PROPERTY OF PDO MONOFILAMENT } \\
\hline \multirow{2}{*}{ Sample } & $\begin{array}{c}\text { Diameter } \\
(\mathbf{m m})\end{array}$ & $\begin{array}{c}\text { Linear } \\
\text { density (dtex) }\end{array}$ & $\begin{array}{c}\text { Tensile property } \\
\text { (cN/dtex) }\end{array}$ & $\begin{array}{c}\text { Elongation } \\
(\%)\end{array}$ & $\begin{array}{c}\text { Bending stiffness } \\
\left(\mathbf{c N} \cdot \mathbf{c m}^{2}\right)\end{array}$ \\
\hline PDO-1 & 0.16 & 327.5 & $3.69 \pm 0.18$ & $48.11 \pm 2.29$ & 0.0511 \\
\hline PDO-2 & 0.23 & 631.2 & $3.55 \pm 0.33$ & $47.62 \pm 3.14$ & 0.2036 \\
\hline PDO-3 & 0.29 & 958.7 & $3.5 \pm 0.18$ & $48.11 \pm 2.29$ & 0.4218 \\
\hline
\end{tabular}




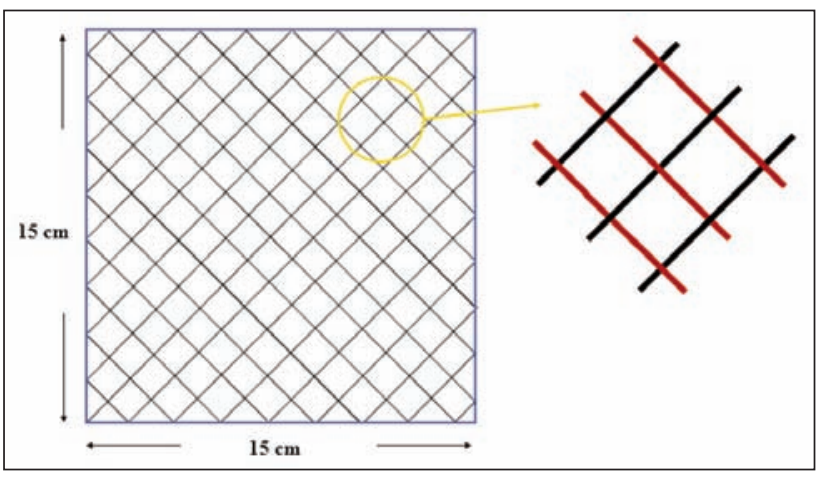

Fig. 3. Design structure of rhombus-pore PDO mesh

$15 \mathrm{~min}$. The number and specifications of PDO meshes prepared in this work were summarized in table 2.

Table 2

\begin{tabular}{|c|c|c|c|}
\hline \multicolumn{4}{|c|}{ SPECIFICATION OF SEVERAL PDO MESHES } \\
\hline Sample & Material & $\begin{array}{l}\text { Pore } \\
\text { shape }\end{array}$ & $\begin{array}{l}\text { Pore } \\
\text { size }\end{array}$ \\
\hline PM-S-1.1 & PDO-1 $0.16 \mathrm{~mm}$ & \multirow{6}{*}{ Square } & \multirow{3}{*}{$5 \mathrm{~mm} \times 5 \mathrm{~mm}$} \\
\hline PM-S-1.2 & PDO-2 $0.23 \mathrm{~mm}$ & & \\
\hline PM-S-1.3 & PDO-3 $0.29 \mathrm{~mm}$ & & \\
\hline PM-S-2.1 & PDO-1 $0.16 \mathrm{~mm}$ & & \multirow{3}{*}{$10 \mathrm{~mm} \times 10 \mathrm{~mm}$} \\
\hline PM-S-2.2 & PDO-2 $0.23 \mathrm{~mm}$ & & \\
\hline PM-S-2.3 & PDO-3 $0.29 \mathrm{~mm}$ & & \\
\hline PM-R-1.1 & PDO-1 $0.16 \mathrm{~mm}$ & \multirow{6}{*}{ Rhombus } & \multirow{3}{*}{$5 \mathrm{~mm} \times 5 \mathrm{~mm}$} \\
\hline PM-R-1.2 & PDO-2 $0.23 \mathrm{~mm}$ & & \\
\hline PM-R-1.3 & PDO-3 $0.29 \mathrm{~mm}$ & & \\
\hline PM-R-2.1 & PDO-1 $0.16 \mathrm{~mm}$ & & \multirow{3}{*}{$10 \mathrm{~mm} \times 10 \mathrm{~mm}$} \\
\hline PM-R-2.2 & PDO-2 $0.23 \mathrm{~mm}$ & & \\
\hline PM-R-2.3 & PDO-3 $0.29 \mathrm{~mm}$ & & \\
\hline
\end{tabular}

\section{Assessment of PDO mechanical property}

Before measurements, all samples were balanced under a standard environment $\left(20^{\circ} \mathrm{C} \pm 2^{\circ} \mathrm{C}, 65 \% \pm 2 \%\right)$ for 24 hours. Each sample was measured for 3 times and took the average for final value.

(1) Surface density

Sample was weighed by FA2004 electronic analytical balance. The surface density was calculated according to equation 1 .

$$
w=m / s
$$

where $m$ refers to sample weight, $s$ refers to sample area.

(2) Thickness

Samples with size of $150 \mathrm{~mm} \times 150 \mathrm{~mm}$ were measured using YG141N fabric thickness tester (Hong Daexperimental Equipment Co., Ltd, China). Pressure was set as $1 \pm 0.01 \mathrm{KPa}$ and last for $30 \pm 5 \mathrm{~s}$.

(3) Bending stiffness

The stiffness was measured according to Standard $\mathrm{GB} / \mathrm{T}$ 18318-2001. Sample was cut into rectangle size of $25 \mathrm{~mm} \times 120 \mathrm{~mm}$ and tested using LLY-01
Fabric Stiffness Tester (Lai Zhou Instruments Co. Ltd, China). Each sample was tested twice one both sides and took the average. The bending stiffness was calculated using the following equation.

$$
G=a \times c^{3} \times 10^{-3}
$$

Where a refers to sample surface density, $c(\mathrm{~cm})-$ sample bending length.

(3) Tensile strength

Sample was cut into $25 \mathrm{~mm} \times 120 \mathrm{~mm}$ rectangle size, measured under HD026N+ electronic strength tester for tensile strength testing (Hong $\mathrm{Da}$ experimental Equipment Co., Ltd, China). Each sample was draw at speed of $100 \mathrm{~mm} / \mathrm{min}$ from a distance of $90 \mathrm{~mm}$ between two chucks, the pre-tension was $3 \mathrm{~N}$.

(4) Bursting strength

Sample with size of $60 \mathrm{~mm} \times 60 \mathrm{~mm}$ circle was measured according to GB/T 19976-2005, also using $\mathrm{HD} 026 \mathrm{~N}+$ electronic strength tester. The initial distance between two chucks was $300 \mathrm{~mm}$, the descend speed was $100 \mathrm{~mm} / \mathrm{min}$.

\section{(5) Suture pulling out force}

Sample with size of $30 \mathrm{~mm} \times 30 \mathrm{~mm}$ square was measured under $\mathrm{YG}(\mathrm{B}) 026 \mathrm{H}-500$ textile multi-function strength tester. The initial distance between sample and chuck was $100 \mathrm{~mm}$, the pre-tension was $0.1 \mathrm{~N}$. Suture was threaded through sample about $3 \mathrm{~mm}$ from edge, draw to breakage at $100 \mathrm{~mm} / \mathrm{min}$. Each sample was measured for 3 times and took the average for final value.

\section{Assessment of PDO in vitro degradation property}

The nutrient solution for degradation test was PH7.2 phosphate buffered solution (PBS) saved under $37^{\circ} \mathrm{C}$. It contained $\mathrm{KCL}(0.2 \mathrm{~g} / \mathrm{l}), \mathrm{NaCl}(8 \mathrm{~g} / \mathrm{L})$, $\mathrm{Na}_{2} \mathrm{HPO}_{4} \cdot 12 \mathrm{H}_{2} \mathrm{O}(2.9 \mathrm{~g} / \mathrm{L})$, and $\mathrm{KH}_{2} \mathrm{PO}_{4}(0.2 \mathrm{~g} / \mathrm{L})$. Sample degradation was mainly decided by material type, therefore only 3 samples with different diameter PDO monofilament composition (PM-S-1.1, PM-S-1.2, PM-S-1.3) were taken into degradation test. Before test, mesh was immersed in anhydrous alcohol, cleaned by deionized water and finally dried in lyophilizer for 2 hours. The dried sample was immersed in PBS solution and cultured in $37^{\circ} \mathrm{C}$ incubator during the whole experiment. The solution was changed each week and sustained for 16 weeks. Samples were taken out each two weeks, dried to a constant weight before measurement. Weight loss weight was calculated according to the following equation.

$$
\text { Weight loss weight }=\left(W_{0}-W_{1}\right) / W_{0} \times 100 \%
$$

Where $W_{0}$ is sample weight before degradation, $W_{1}$ - sample weight after degradation.

\section{RESULTS AND DISCUSSION}

\section{Analysis of PDO monofilaments' mechanical property}

The PDO meshes were fabricated using 3 kinds of PDO monofilaments with diameter ranging from $0.16 \mathrm{~mm}$ to $0.29 \mathrm{~mm}$. The mechanical properties of 
PDO monofilaments were summarized in table 3 . Even with different diameter, 3 types of monofilaments still have similar bursting strength and elongation at break. Moreover, they are stronger than most other polymer monofilaments, with strength larger than $30 \mathrm{cN} \cdot$ tex $^{-1}$ and elongation larger than $45 \%$. PDO macromolecular has good regularity, resulting in its higher degree of crystallinity and orientation after being spun to filaments. The superiority could strength the whole mesh's bursting strength and support prolapsed organs stably [9].

The large amounts of enter linkage in PDO macromolecular is able to increase its flexibility, manifest as high elongation rate. This would lead to a slightly growing strength, reduced initial modulus with the increase of monofilament diameter.

From table 3, it was found that the thicker monofilament had larger stiffness. Stiffness was related to monofilament equivalent flexural modulus and inertia moment. Equivalent flexural modulus is a material nature mainly decided by molecular structure, while inertia moment is decided by monofilament diameter and cross-section shape. The inertia moment of PDO monofilaments used in this experiment was growing along with the increased diameter in compression, leading to a higher stiffness.

\section{Effect of monofilament diameter on PDO mesh}

Table 4 presents three PDO meshes' structural parameters and mechanical properties. The adopted 3 samples have same pore size and pore shape, but different diameter filaments composition. The effect of monofilament diameter on mesh property was analyzed after then.

PDO mesh's surface density and thickness were significantly growing along with the increase of monofilament diameter. The diameter's effect on mesh stiffness and tensile strength was much obvious, mesh became stiffer and stronger when used a thicker monofilament in mesh preparation. Because of the mixing effect of glue addition around filament bonding point, the relationship of diameter and mesh suture pulling out force was unclear. Although, there is no particular law between diameter and bursting strength that sample PM-S-2.3 had significantly advantage in bursting property.

Overall, larger diameter would make mesh be heavier, stiffer and stronger. However, the consequents were unexpected for human sensation after implantation. The softness, lightweight and flexibility were the future development of medical mesh. Based on that, sample PM-S-2.2 with the largest suture pulling out force, moderate surface density was considered of an optimal choice. PDO monofilament with diameter of $0.23 \mathrm{~mm}$ was adopted for the following study.

\section{Effect of pore-shape on PDO mesh}

After discussion of monofilament diameter's effect, the $0.23 \mathrm{~mm}$ was considered to bean optimal choice. Table 5 presents samples consisted of $0.23 \mathrm{~mm}$ monofilaments, but designed to different poreshapes. The effect of pore-shape on mesh property could be studied.

Mesh samples with same pore-size but different pore-shape (PM-S-1.2 VS PM-R-1.2, PM-S-2.2 VS PM-R-2.2) were compared in this experiment. Poreshape was proved to have little effect on mesh surface density, thickness and bursting strength. However, bending stiffness, tensile strength and suture pulling out force were largely influenced. Rhombus-pore shape lead mesh to have small tensile strength but large suture pulling out force. Differently, square-pore shape decided mesh to have a small suture pulling out force but large tensile strength. However, the influence of pore shape on bending stiffness was unclear.

Two groups of samples had different pore shape but the same pore size and material composition. Therefore, the meshes had same density leading to similar mesh thickness and weight. And also, compared with tensile strength, bursting strength was

Table 3

\begin{tabular}{|c|c|c|c|c|}
\hline \multicolumn{5}{|c|}{ MECHANICAL PROPERTY OF PDO MONOFILAMENTS } \\
\hline Sample & $\begin{array}{c}\text { Elongation at break } \\
(\mathbf{\%})\end{array}$ & $\begin{array}{c}\text { Bursting strength } \\
\left(\mathbf{c N} \cdot \mathbf{t e x}^{-1}\right)\end{array}$ & $\begin{array}{c}\text { Initial modulus } \\
\left(\mathbf{N} \cdot \mathbf{t e x}^{-\mathbf{1}}\right)\end{array}$ & $\begin{array}{c}\text { Bending stiffness } \mathbf{G} \\
(\mathbf{c N} \cdot \mathbf{c m})\end{array}$ \\
\hline PDO-1 & 45.334 .12 & 35.683 .42 & 1.220 .11 & 0.0511 \\
\hline PDO-2 & 44.813 .86 & 36.492 .05 & 1.190 .06 & 0.2036 \\
\hline PDO-3 & 47.904 .47 & 38.191 .93 & 1.160 .10 & 0.4218 \\
\hline
\end{tabular}

STRUCTURAL AND MECHANICAL PROPERTIES OF PDO MESHES WITH DIFFERENT DIAMETERS

\begin{tabular}{|c|c|c|c|c|c|c|}
\hline Sample & $\begin{array}{c}\text { Surface density } \\
\left(\mathbf{g} \cdot \mathbf{m}^{-2}\right)\end{array}$ & $\begin{array}{c}\text { Thickness } \\
(\mathbf{m m})\end{array}$ & $\begin{array}{c}\text { Stiffness } \\
(\mathbf{m} \mathbf{N} \cdot \mathbf{c m})\end{array}$ & $\begin{array}{c}\text { Tensile strength } \\
(\mathbf{N})\end{array}$ & $\begin{array}{c}\text { Bursting } \\
\text { strength (N) }\end{array}$ & $\begin{array}{c}\text { Suture pulling } \\
\text { out force }(\mathbf{N})\end{array}$ \\
\hline PM-S-2.1 & 7.260 .32 & 0.540 .05 & 0.210 .01 & 15.421 .12 & 9.430 .72 & 1.380 .10 \\
\hline PM-S-2.2 & 13.510 .10 & 0.590 .04 & 2.090 .12 & 17.681 .60 & 7.140 .52 & 2.450 .20 \\
\hline PM-S-2.3 & 16.840 .15 & 0.720 .05 & 2.420 .15 & 40.442 .87 & 16.751 .15 & 1.510 .08 \\
\hline
\end{tabular}


STRUCTURAL AND MECHANICAL PROPERTIES OF PDO MESHES WITH DIFFERENT PORES

\begin{tabular}{|c|c|c|c|c|c|c|}
\hline Sample & $\begin{array}{c}\text { Surface density } \\
\left(\mathbf{g} \cdot \mathbf{m}^{-\mathbf{2}} \mathbf{)}\right.\end{array}$ & $\begin{array}{c}\text { Thickness } \\
(\mathbf{m m})\end{array}$ & $\begin{array}{c}\text { Stiffness } \\
(\mathbf{m N} \cdot \mathbf{c m})\end{array}$ & $\begin{array}{c}\text { Tensile strength } \\
\mathbf{( N )}\end{array}$ & $\begin{array}{c}\text { Bursting } \\
\text { strength }(\mathbf{N})\end{array}$ & $\begin{array}{c}\text { Suture pulling } \\
\text { out force }(\mathbf{N})\end{array}$ \\
\hline PM-S-1.2 & 28.21 .30 & 0.650 .02 & 38.53 .19 & 23.801 .55 & 12.80 .71 & 2.630 .12 \\
\hline PM-S-2.2 & 15.11 .07 & 0.570 .04 & 2.270 .18 & 13.781 .32 & 6.840 .42 & 1.470 .08 \\
\hline PM-R-1.2 & 27.31 .78 & 0.690 .03 & 38.62 .27 & 7.560 .57 & 13.61 .09 & 3.680 .22 \\
\hline PM-R-2.2 & 13.030 .82 & 0.590 .03 & 4.160 .32 & 6.110 .50 & 7.020 .61 & 1.960 .12 \\
\hline
\end{tabular}

used to characterize overall strength of mesh, not affected by testing direction, mainly relied on mesh density, material's specification.

When testing mesh tensile strength, drawing point concentrated on bonding area. The two monofilaments forming rhombus-pore shape were bonded by medical glue, its force was much less than that of monofilament itself. Therefore, the tensile strength of square pore-shape mesh was much smaller than that of rhombus mesh. However, the square pore-shape brought about a small suture pulling out force for medical mesh, the different was not such significant. Based on that, square pore-shape was considered to be superior to rhombus pore-shape.

\section{Effect of pore-size on PDO mesh}

The relationship between pore- size and mesh property could be obtained from table 5 . Two groups (PM-S-1.2 VS PM-S-2.2 and PM-R-1.2 VS PM-R2.2) were compared. Along with the pore-size increase, mesh's surface density, thickness, bending stiffness, tensile strength, bursting strength and suture pulling out force all reduced. PDO mesh could be lighter and thinner, but also weaker in strength. However, the mesh only decreased $0.1 \mathrm{~mm}$ in thickness property, but largely reduced in strength property when pore-size increased from $5 \mathrm{~mm}$ to $10 \mathrm{~mm}$. PDO mesh's thickness mainly depended on consisted monofilament's diameter. The selected PDO mesh in table 5 were all composed of $0.23 \mathrm{~mm}$ monofilament, as a result, the meshes had similar thickness values.

The fabricated PDO meshes in this work all had extremely low weight, even satisfied requirements of ultra-lightweight mesh $\left(<35 \mathrm{~g} / \mathrm{m}^{2}\right)$ [10]. However, the resulting decline in mesh strength is unexpected. Overall, the sample PM-S-1.2 with square poreshape and $5 \mathrm{~cm}$ pore-size were regarded as more suitable for application in repairing tissue defects.

\section{In vitro degradation property of PDO mesh}

Figure 4 shows weight loss rate of three PDO meshes consisted of different monofilament sizes. It can be found that meshes all degraded slowly in the first 10 weeks and then fast, with weight loss rate reaching to $30 \%$ in the $16^{\text {th }}$ week. In the initial stage of degradation, the ester linkage in PDO backbone was hydrolytic broken, releasing small molecules into the nutrient solution, leading to a slow decrease in weight loss. After then, more generated hydroxyl appeared, resulting in autocatalysis, a much more obvious of degradation phenomenon was discovered.

Among samples with different monofilament size, the PM-S-1.1 had significantly fast degradation speed. The small diameter of monofilaments with large specific surface area made sample to be fully immersed into cultured solution. The molecule chain could be more easily attacked to breakage under hydrolysis, clear evidence of weight loss could be observed.

Overall, PDO meshes had superior degradation property. PDO macromolecular chain is gradually degraded to small molecules which are swallowed by tissue cell, absorbed or excreted to the outside of the body along with metabolism. In the last step of repair, the weight loss of PDO mesh in patient body is good for relieving foreign body sensation, improve life quality.

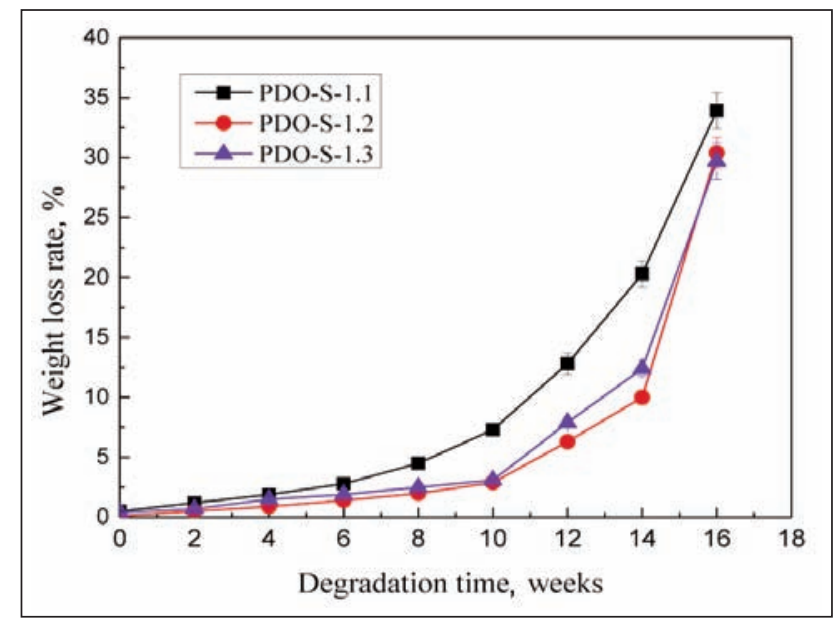

Fig. 4. Weight loss rate of PDO meshes in vitro degradation property

\section{Comprehensive evaluation of PDO mesh}

Figure 5 and figure 6 summarize structural parameters and mechanical properties of five commercial PP meshes, respectively [11-13]. Among them, Marlex ${ }^{\circledR}$ from US Bard Corp is a heavyweight type mesh (>90 $\mathrm{g} / \mathrm{m}^{2}$ ), Prolenesoft ${ }^{\circledR}$ and Gynemesh ${ }^{\circledR}$ from Ethicon are lightweight types $\left(50 \sim 35 \mathrm{~g} / \mathrm{m}^{2}\right)$, Polyform Lite ${ }^{\circledR}$ provided by Marlboroug and Restorelle ${ }^{\circledR}$ mesh from AU Coloplast Corp are both ultra-lightweight types $\left(50 \sim 35 \mathrm{~g} / \mathrm{m}^{2}\right)$. Because of the limited information available, some important structural parameters could not be obtained, e.g. porosity of Marlex ${ }^{\circledR}$ and prolene soft ${ }^{\circledR}$. And also, properties such as stiffness 

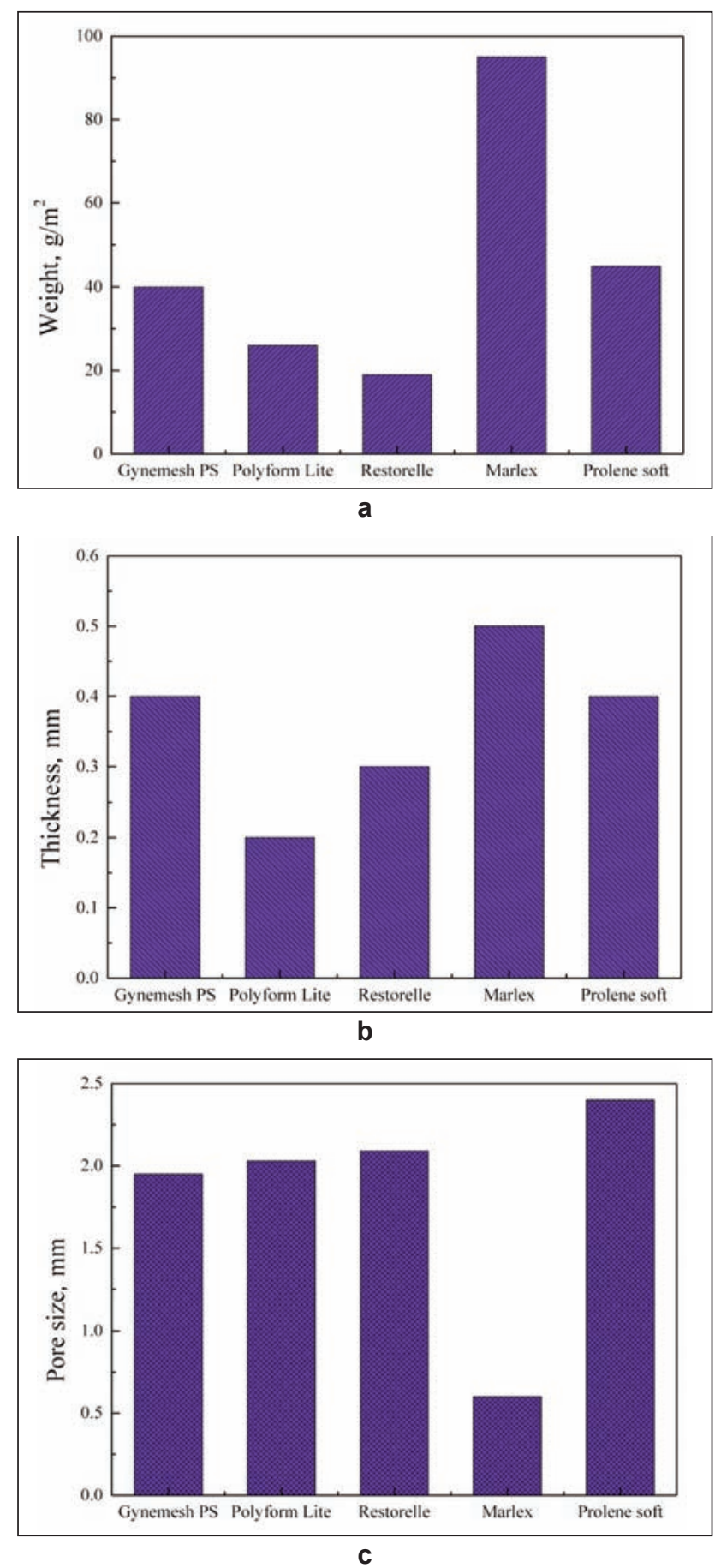

Fig. 5. Structural parameters of 5 commercial meshes: $a$ - weight; $b$ - thickness; $c$ - pore size

and breaking strength of Gynemesh ${ }^{\circledR}$ could only be determined within a scope instead of an accurate value.

By comparison to the above mentioned commercial mesh, PDO mesh is considered to have obvious weight advantage (figure 5,a). The fabricated PDO mesh in this work had weight ranging from $7.3 \mathrm{~g} / \mathrm{m}^{2}$ to $28.0 \mathrm{~g} / \mathrm{m}^{2}$, the extremely little retention of material in human body could relieve discomfort sensory. However, the thickness of PDO mesh (0.59 0.71 $\mathrm{mm}$ ) was much larger than that of PP mesh (less than $0.5 \mathrm{~mm}$ ), (figure $5, b)$. This is related to the large diameter PDO monofilament $(0.16 \sim 0.29 \mathrm{~mm})$ used in this work while PP monofilament used in commercial
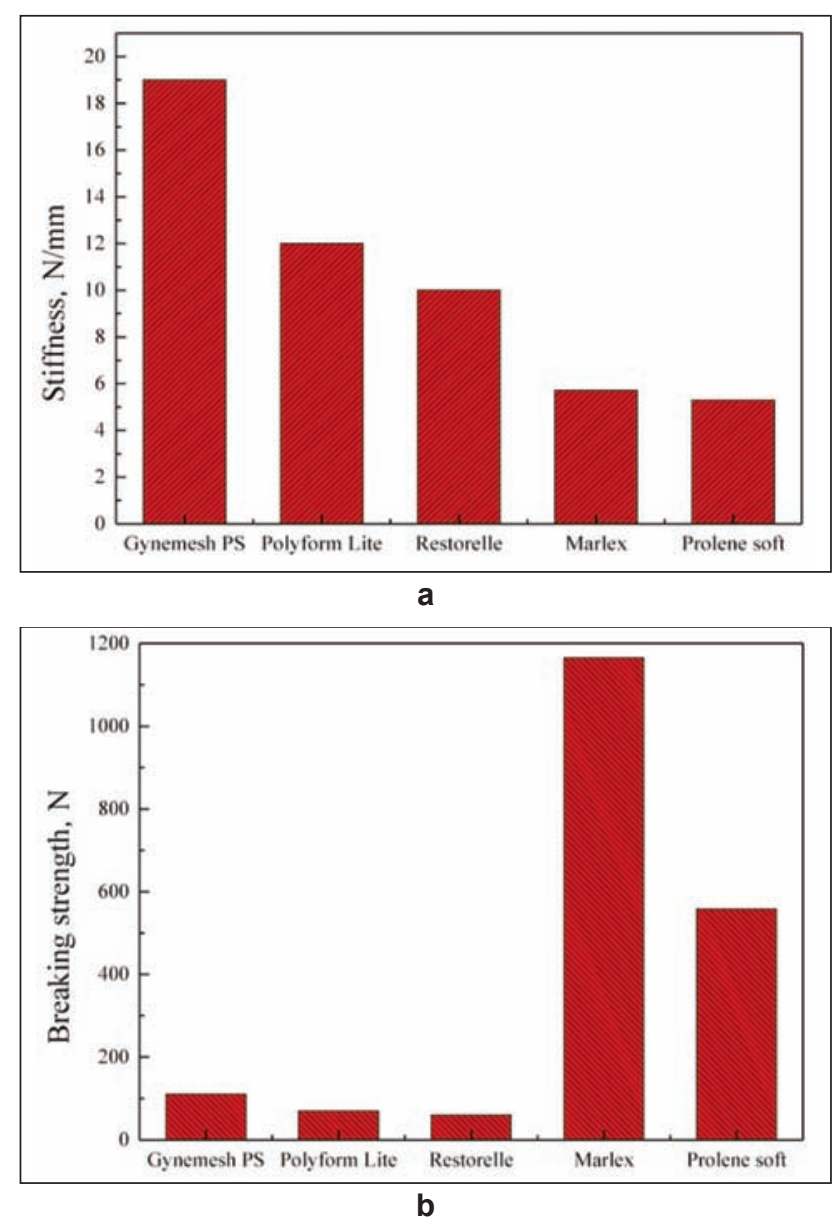

Fig. 6. Mechanical properties of 5 commercial meshes: $a$ - stiffness; $b$ - breaking strength

mesh were $0.08 \mathrm{~mm}$ (Polyform Lite ${ }^{\circledR}$ ) or $0.10 \mathrm{~mm}$ (Polyform Lite ${ }^{\circledR}$ ).

There is no comparability between PDO mesh's stiffness and PP mesh's because of the adopted different measurement method (figure 6, a). Strong contradiction also existed among PP mesh's stiffness itself, e.g. heavier Marlex ${ }^{\circledR}$ mesh's stiffness was reported to be much smaller than that of most lightweight meshes. Even more, the same type product was reported to be different stiffness in different reviews. The nonuniform measuring method and index used leading to the difficulty in evaluating mesh stiffness.

The PDO mesh's breaking strength was much smaller than that of PP mesh (figure $6, b$ ). Mesh strength are related to several parameters, such as mesh weight and material type. The strength of heavyweight mesh is always larger than that of lightweight mesh using the same type material.

Overall, PDO mesh has advantage of ultra-lightweight, but the resulting weak strength limited its application. Different to hernia mesh's replacement to the original tissue, pelvic floor mesh mostly supported or reinforced the weak tissues. Large strength is not a primary requirement for pelvic floor mesh, lightweight and high porosity could improve its effect.

\section{CONCLUSION}

Three types of PDO monofilaments with different diameter were used for mesh preparation in this 
work. The effect of monofilament property, mesh pore-shape and pore-size were discussed for optimize PDO mesh fabrication process. Monofilament diameter of $0.23 \mathrm{~mm}$ was considered to be the most suitable choice based on the balance between weight and strength. Square-pore shape made PDO mesh to have extremely larger tensile strength. Although pore-size of $10 \mathrm{~mm}$ lead mesh to be lighter, the resulted significantly reduced strength was unexpected. By comparison to some widely-used commercial meshes, PDO mesh was assessed to have ultralightweight advantage. However, its application in repairing pelvic floor defects needs more clinical study in future.

\section{ACKNOWLEDGEMENTS}

This study was funded by Ningbo Natural Science Fund (Grant No. 2018A610116), Zhejiang Provincial public welfare technology application \& research plan (Grant No. LGG18E030006), and foundation of Inner Mongolia Scientific Research of University (No. NJZY18095).

\section{BIBLIOGRAPHY}

[1] Özdemır, Ö. Ç., Bakar, Y., Özengın, N., et al. The effect of parity on pelvic floor muscle strength and quality of life in women with urinary incontinence: a cross sectional study, In: Journal of Physical Therapy Science, Jul 2015, vol. 27, no. 7, pp. 2133-2137.

[2] Novitsky, Y., Harrell, A. J., Paton, B., et al. Comparative evaluation of adhesion formation, strength of in growth, and textile properties of prosthetic meshes after long-term intra-abdominal implantation in a rabbit. In: Journal of Surgical Research, Jun 2007, vol .140, no. 1, pp. 6-11.

[3] Hilde, G., Stær-Jensen, J., Siafarikas, F., et al. Impact of childbirth and mode of delivery on vaginal resting pressure and on pelvic floor muscle strength and endurance, In: American Journal of Obstetrics and Gynecology, Oct 2013, vol. 208 , no. 1 , pp. $1-7$

[4] Costantini, E., Lazzeri, M., Bini, V., et al. Pelvic organ prolapse repair with and without prophylactic concomitant burchcolpo suspension in continent women: A randomized, controlled trial with 8-year follow up.In: Journal of Urology. Jun 2011, vol.185, pp. 2236-2240.

[5] Brown, C. N., Finch, J. G. Which mesh for hernia repair?, In: Annals of the Royal College of Surgeons of England, May 2010, vol. 92, no. 4, pp. 272-278.

[6] Junyao, C., Tianhui, W., Deng, D., et al. The degradation property of a Netty Structure Scaffold Reinforcement for Tendon Tissue Engineering, In: Journal of Donghua University (Natural Science), Oct 2010, vol. 36, no. 5, pp. 491-495.

[7] Gemma, P., Belén, H. G., Marta, R., et al. The long-term behavior of lightweight and heavyweight meshes used to repair abdominal wall defects is determined by the host tissue repair process provoked by the mesh, In: Surgery, May 2012, vol. 152, no. 5, pp. 886-895.

[8] Lu Y., Chen Y C., Zhang P. H., Effects of porosity on structure and performance of PP meshes for repairng pelvic floor defects. In: Journal of DonghuaUniversity (English Edition), May 2014, vol. 31, no. 5, pp. 704-708.

[9] Liang, R., Abramowitch, S., Knight, K., et al. Vaginal degeneration following implantation of synthetic mesh with increased stiffness, In: Bjog-Int J ObstetGy, Jan 2013, vol. 120, no. 2, pp. 233-43.

[10] Deeken, C. and Matthews, B. Comparison of contracture, adhesion, tissue in growth, and histologic response characteristics of permanent and absorbable barrier meshes in a porcine model of laparoscopic ventral hernia repair, In: Jul Hernia, 2012, vol. 16, no. 1, pp. 69-76.

[11] Klosterhalfen, B., Junge, K., Klinge, U. The lightweight and large porous mesh concept for hernia repair, In: Expert Review of Medical Devices, 2005, vol. 2, no. 1, pp. 103-17.

[12] Ulrich, D., Edwards, S. L., Alexander, D. L., et al. Changes in pelvic organ prolapse mesh mechanical properties following implantation in rats, In: American Journal of Obstetrics \& Gynecology, 2015, vol. 214, no. 2, pp. 260.e1-260.e8.

[13] Pott, P. P., Schwarz, M. L. R., Ralf, G., et al. Mechanical properties of mesh materials used for hernia repair and soft tissue augmentation, In: Plos One, 2012, vol. 7, no. 10, pp. 4821-4836.

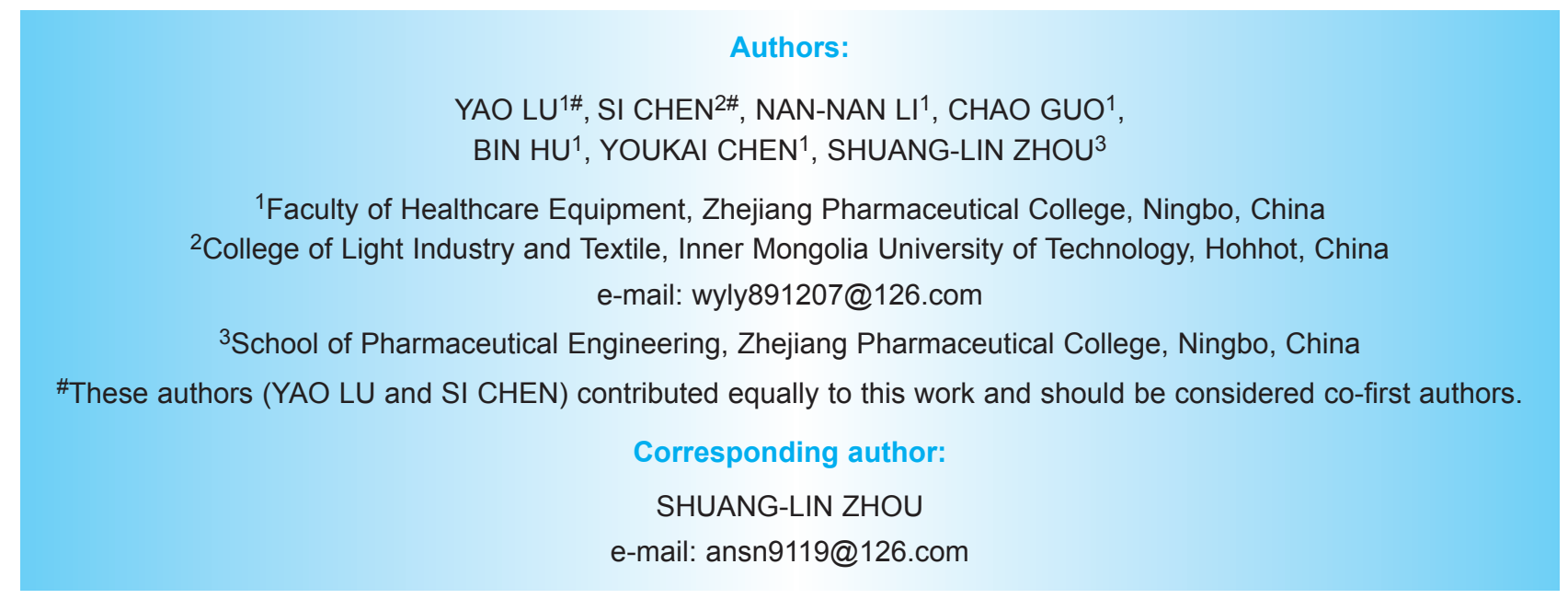




\section{Properties of textile and leather materials treated with new hybrid $\mathrm{SiO}_{2} / \mathrm{TiO}_{2} /$ poly $(2,2$ '-bithiophene) nanocomposites \\ DOI: $10.35530 / I T .070 .03 .1634$}

\section{REZUMAT - ABSTRACT}

Proprietățile materialelor textile și din piele tratate cu noi nanocompozite hibride pe bază de $\mathrm{SiO}_{2} / \mathrm{TiO}_{2} /$ poli(2,2'-bitiofen)

Scopul acestui studiu a fost de a investiga influența nanocompozitelor noi pe bază de $\mathrm{SiO}_{2} / \mathrm{TiO}_{2} /$ poli(2 2'-bitiofen) cu concentrații diferite de nanoparticule de $\mathrm{TiO}_{2}$ și $\mathrm{SiO}_{2}$ asupra proprietăților de suprafață a țesăturii din $50 \%$ bumbac/50\% poliester si respectiv, pielii de ovină. Dispersiile realizate pe baza noilor nanocompozite au fost analizate în scopul determinării conductivității, dimensiunii particulelor, polidispersității și al potențialului Zeta. Materialele textile și din piele finisate au fost caracterizate din punctul de vedere al peformantei tratamentelor de functionalizare, prin: rezistivitatea de suprafață, comportarea la contactul cu apa, caracteristicile fizico-mecanice și proprietățile fotocatalitice. Microscopia electronică de baleiaj a fost utilizată pentru a investiga distribuția nanoparticulelor pe suprafața materialelor textile și din piele. Materialele textile tratate cu nanocompozitul hibrid pe bază de $\mathrm{SiO}_{2} /$ poli(2,2'-bitiofen) cu concentrație de $98 \% \mathrm{SiO}_{2}$ și, respectiv, pielea tratată cu $\mathrm{SiO}_{2}$ /poli(2,2'-bitiofen) cu concentrație de 95\% nanoparticule de $\mathrm{SiO}_{2}$ au prezentat valori ale rezistivității mai mici, confirmând astfel proprietățile conductive ale dioxidului de siliciu. Cea mai ridicată eficiență fotocatalitică a materialelor funcționalizate a fost obținută în cazul materialului textil tratat cu TiO_/poli(2,2'-bitiofen) cu concentratie de $95 \%$ nanoparticule de $\mathrm{TiO}_{2}$ și, respectiv, pentru pielea tratată cu $\mathrm{TiO}_{2} /$ poli(2,2'-bitiofen) cu concentrație de $98 \%$ nanoparticule de $\mathrm{TiO}_{2}$.

Cuvinte-cheie: nanocompozite hibride, nanocompozite pe bază de $\mathrm{TiO}_{2} / \mathrm{SiO}_{2} /$ poli(2,2'-bitiofen), rezistivitate de suprafață, proprietăți fotocatalitice, țesătură din $50 \%$ bumbac/50\% poliester, suprafață din piele

\section{Properties of cotton and leather materials treated with new hybrid $\mathrm{SiO}_{2} / \mathrm{TiO}_{2} /$ poly $\left(2,2^{\prime}\right.$-bithiophene $)$} nanocomposites

The aim of this study was to investigate the influence of new hybrid composites of $\mathrm{TiO}_{2}$ or $\mathrm{SiO}_{2}$ nanoparticles with poly(2,2'bithiophene) on $50 \%$ cotton $/ 50 \%$ polyester fabric and sheep skin leather surface properties. The dispersion-based newly made nanocomposites were analyzed to determine conductivity, particle size, polydispersity and Zeta potential. The finished textile and leather materials were characterized in terms of functionalization treatments performance by: surface resistivity, water contact behaviour, physical-mechanical characteristics and photocatalytic properties. SEM analysis was used to investigate the distribution of nanoparticles on the textile and leather materials surface. Textile materials treated with $\mathrm{SiO}_{2} /$ poly $\left(2,2^{2}\right.$-bithiophene) nanocomposite with concentration 98 wt\% nanoparticles of $\mathrm{SiO}_{2}$ and leather treated with poly $\mathrm{SiO}_{2}$ /poly(2,2'-bithiophene) nanocomposite with concentration of $95 \mathrm{wt} \%$ nanoparticles of $\mathrm{SiO}_{2}$ showed lower resistivity values, confirming the conductive properties of silica. The higher photodegradation efficiency of functionalized materials has been obtained for textile material treated with poly $\mathrm{TiO}_{2} /(2,2$ '-bithiophene)with concentration of 95 wt\% nanoparticles of $\mathrm{TiO}_{2}$ and for leather material treated with $\mathrm{TiO}_{2} /$ poly $(2,2$ '-bithiophene) with concentration of 98 wt\% nanoparticles of $\mathrm{TiO}_{2}$, respectively.

Keywords: hybrid nanocomposite, $\mathrm{TiO}_{2} / \mathrm{SiO}_{2} /$ poly(2,2'-bithiophene) nanocomposites, surface resistivity, photocatalytic properties, $50 \%$ cotton $/ 50 \%$ polyester fabric, leather surface

\section{INTRODUCTION}

Textile and leather material functionalization by using nanocomposites is a top research priority for smart finishing and multifunctional properties development [1-2]. Through synergic influence of polymers on nanomaterial composite, nanocomposites can add new properties such as: antibacterial [3], UV shielding, electrostatic charge dissipation, antistatic or conductive properties, water, oil, soil repellence, moisture management, flame retardancy, abrasion resistance, biocompatibility [4] etc. In the last years the use of conducting polymers [5-6] for flexible electronic textiles or leathers were studied and experimented using poly(3,4-ethylenedioxythiophene) [7], poly(fluorene), polyphenylene, polypyrene, polyazulene, polynaphthalene, poly(pyrrole) [8], polycarbazole, polyindole, polyazepine, polyaniline [9], poly(thiophene) [10-11], and poly(p-phenylene)sulphide in combination with metals (iron, cobalt, nickel, copper, palladium, silver, platinum, gold) or carbon based materials (graphite, carbon nanotubes, and carbon black). Traditional textiles, both natural and synthetic, and leather materials are almost always insulators. The interest in transforming them into conductors arises from the need to obtain antistatic or electromagnetic shielding garments, or for the production of the flexible electronic 
textiles or leather. Textile fibres including natural fibres and synthetic fibres are generally intrinsically nonconductive. Static charges are often formed in synthetic fibres, especially in dry environment. The static charges are generated by the motion of textile surfaces and during this process, negative charges are generated and accumulated on one surface and positive ones on the other surface. The negatively charged textile material has a stronger affinity for electrons that it steals from the other textile material after the two textile materials are separated. For textile materials synthetic fibres have more static problems compared with natural fibres. Hydrophilic chemical materials and moisture drastically decrease textile and leather resistivity with effect on static electric charges dissipation rate increase and conductive properties development for 95\% humidity [12].

There are few studies regarding the functionalization of textile and leather materials by using hybrid $\mathrm{TiO}_{2} /$ $\mathrm{SiO}_{2} /$ poly(2,2'-bithiophene) nanocomposites and the influence of treatment technologies on their surface properties. Multifunctional properties of fibrous material surfaces for daily and professional clothes and footwear are very important and offer the perspective of green solutions with competitive costs [13]. In our research we have investigated the influence of new hybrid nanocomposites of $\mathrm{SiO}_{2} / \mathrm{TiO}_{2} /$ poly(2,2'-bithiophene) on $50 \%$ cotton/ $50 \%$ polyester fabric and sheep skin leather surface properties. The aim of the investigations was the functionalisation of different fibrous materials in view of new added value products development. In this regard the surface resistivity, water contact behaviour, physico-mechanical characteristics and photocatalytic properties were investigated.

\section{EXPERIMENTAL}

\section{Materials}

For laboratory experiments the blended $50 \%$ cotton/ $50 \%$ polyester fabric with $218 \mathrm{~g} / \mathrm{m}^{2}$ and ecological sheepskin leathers processed in Leather Research Department have been used. Itobinder AG, an acrylic copolymer supplied from LJ Specialities (UK) has been used as binder in order to fix the polymeric nanocomposites on the surface of textile materials. Acrylic film forming polymers and nitrocellulose based emulsion purchased from SC Triderma SRL, were used for leather surface finishing.

Different $\mathrm{SiO}_{2} / \mathrm{TiO}_{2} /$ poly(2,2'-bithiophene) hybrid nanocomposites were prepared in INCDTFM' laboratories by making a microemulsion of dioctylsulfosuccinate sodium salt $\left(1.5 \times 10^{-3} \mathrm{~mol}\right)$ in $50 \mathrm{~mL}$ of $\mathrm{n}$-hexane to which were subsequently added: i) $\mathrm{FeCl}_{3}$ aqueous solution $\left(2 \times 10^{-2} \mathrm{~mol}\right.$ in $\left.1 \mathrm{~mL} \mathrm{H}_{2} \mathrm{O}\right)$; ii) various $\mathrm{SiO}_{2}$ or $\mathrm{TiO}_{2}$ nanoparticles quantities (0.5 and $1 \mathrm{~g})$ and iii) 2,2'-bithiophene $\left(2 \times 10^{-3} \mathrm{~mol}\right)$. This reaction mixture was homogenized by ultrasonication and mechanical agitation for 2 hours when red-violet precipitates were obtained. Then, these precipitates were washed with ethanol, filtered and dried until reaching constant mass. Dispersions of nanocomposites

\begin{tabular}{|c|c|}
\hline \multicolumn{2}{|c|}{$\begin{array}{l}\text { CODIFICATION OF NANOCOMPOSITES USED } \\
\text { FOR FUNCTIONALIZATION }\end{array}$} \\
\hline Nanocomposites & Codification \\
\hline $\begin{array}{l}\text { Poly (2,2'-bithiophene) with } 98 \% \text { wt } \% \\
\text { nano } \mathrm{SiO}_{2}\end{array}$ & PBTh-SiO $2 / 1$ \\
\hline $\begin{array}{l}\text { Poly (2,2'-bithiophene) with } 95 \% \text { wt\% } \\
\text { nano } \mathrm{SiO}_{2}\end{array}$ & PBTh-SiO $2 / 0.5$ \\
\hline $\begin{array}{l}\text { Poly }(2,2 \text { '-bithiophene) with } 98 \% \text { wt\% } \\
\text { nanoTiO }_{2}\end{array}$ & PBTh- $-\mathrm{TiO}_{2} / 1$ \\
\hline $\begin{array}{l}\text { Poly }(2,2 \text { '-bithiophene) with } 95 \% \text { wt } \% \\
\text { nano } \mathrm{TiO}_{2}\end{array}$ & $\mathrm{PBTh} \mathrm{TiO}_{2} / 0.5$ \\
\hline
\end{tabular}

presented in table 1 were prepared by 30 minutes ultrasound stirring of $2 \mathrm{mg}$ nanopowders in $10 \mathrm{~mL}$ ultrapure water.

\section{Functionalization treatments of textile and leather materials}

\section{Functionalization of textile materials}

Prior to functionalization treatments the textile fabrics were subjected to preliminary preparation by hot alkaline treatment and bleaching. The immobilization of nanocomposites dispersions on $50 \%$ cotton $/ 50 \%$ polyester fabrics was performed by padding on the laboratory padder, under the following conditions: 2 passes, 2 bar squeezing pressure. Drying and curing of textile materials was made on the drying/curing/ heat-setting/vaporization, model TFO/S $500 \mathrm{~mm}$ (ROACHES, UK). The samples codification, technological parameters and the composition of treatment baths are found in the table 2 . The aspect of

Table 2

\begin{tabular}{|c|c|c|}
\hline \multicolumn{3}{|c|}{$\begin{array}{c}\text { THE CODIFICATION OF EXPERIMENTAL VARIANTS FOR } \\
\text { TEXTILE MATERIALS, TECHNOLOGICAL PARAMETERS, } \\
\text { COMPOSITION OF THE TREATMENT BATHS }\end{array}$} \\
\hline Code & $\begin{array}{l}\text { Content of } \\
\text { treatment bath }\end{array}$ & $\begin{array}{l}\text { Technological } \\
\text { parameters }\end{array}$ \\
\hline $1 V_{1}$ & PBTh- $\mathrm{TiO}_{2} / 0.5$ & $\begin{array}{l}\text { 1. Padding; } \\
\text { 2. Drying: } 100^{\circ} \mathrm{C}, 120 \mathrm{~s}\end{array}$ \\
\hline $1 V_{2}$ & $\begin{array}{l}\mathrm{PBTh}-\mathrm{TiO}_{2} / 0.5 \\
20 \mathrm{~g} / \mathrm{L} \text { Itobinder AG }\end{array}$ & $\begin{array}{l}\text { 1. Padding; } \\
\text { 2. Drying: } 100^{\circ} \mathrm{C}, 120 \mathrm{~s} \text {; } \\
\text { 3. Curing: } 150^{\circ} \mathrm{C}, 240 \mathrm{~s}\end{array}$ \\
\hline $2 V_{1}$ & PBTh- $\mathrm{TiO}_{2} / 1$ & $\begin{array}{l}\text { 1. Padding; } \\
\text { 2. Drying: } 100^{\circ} \mathrm{C}, 120 \mathrm{~s}\end{array}$ \\
\hline $2 V_{2}$ & $\begin{array}{l}\mathrm{PBTh}-\mathrm{TiO}_{2} / 1 \\
20 \mathrm{~g} / \mathrm{L} \text { Itobinder AG }\end{array}$ & $\begin{array}{l}\text { 1. Padding; } \\
\text { 2. Drying: } 100^{\circ} \mathrm{C}, 120 \mathrm{~s} \text {; } \\
\text { 3. Curing: } 150^{\circ} \mathrm{C}, 240 \mathrm{~s}\end{array}$ \\
\hline $3 V_{1}$ & $\mathrm{PBTh} \mathrm{SiO}_{2} / 0.5$ & $\begin{array}{l}\text { 1. Padding; } \\
\text { 2. Drying: } 100^{\circ} \mathrm{C}, 120 \mathrm{~s}\end{array}$ \\
\hline $3 V_{2}$ & $\begin{array}{l}\mathrm{PBTh}-\mathrm{SiO}_{2} / 1 \\
20 \mathrm{~g} / \mathrm{L} \text { Itobinder AG }\end{array}$ & $\begin{array}{l}\text { 1. Padding; } \\
\text { 2. Drying: } 100^{\circ} \mathrm{C}, 120 \mathrm{~s} \text {; } \\
\text { 3. Curing: } 150^{\circ} \mathrm{C}, 240 \mathrm{~s}\end{array}$ \\
\hline $4 V_{1}$ & $\mathrm{PBTh} \mathrm{SiO}_{2} / 0.5$ & $\begin{array}{l}\text { 1. Padding; } \\
\text { 2. Drying: } 100^{\circ} \mathrm{C}, 120 \mathrm{~s} \text {; }\end{array}$ \\
\hline $4 V_{2}$ & $\begin{array}{l}\mathrm{PBTh}-\mathrm{SiO}_{2} / 1 \\
20 \mathrm{~g} / \mathrm{L} \text { Itobinder AG }\end{array}$ & $\begin{array}{l}\text { 1. Padding; } \\
\text { 2. Drying: } 100^{\circ} \mathrm{C}, 120 \mathrm{~s} \text {; } \\
\text { 3. Curing: } 150^{\circ} \mathrm{C}, 240 \mathrm{~s}\end{array}$ \\
\hline
\end{tabular}




\begin{tabular}{|c|c|c|c|c|c|}
\hline \multicolumn{2}{|c|}{$\begin{array}{l}\text { Material: } \\
\text { Crust ecological sheepskin }\end{array}$} & \multicolumn{4}{|c|}{$\begin{array}{c}\text { Finishing technology for samples: } \\
\text { Control, } \mathrm{PBTh}-\mathrm{SiO}_{2} / 1-\mathrm{L} 1 ; \mathrm{PBTh}_{-} \mathrm{SiO}_{2} / 1-\mathrm{L} 2 \\
\text { PBTh- } \mathrm{TiO}_{2} / 1-\mathrm{L} 3, \mathrm{PBTh}-\mathrm{TiO}_{2} / 0.5-\mathrm{L} 4\end{array}$} \\
\hline \multicolumn{6}{|c|}{ Color: yellow } \\
\hline \multirow{2}{*}{ No } & \multirow{2}{*}{$\begin{array}{l}\text { Materials for leather surface } \\
\text { finishing }\end{array}$} & \multicolumn{3}{|c|}{ Layer, mL/L } & \multirow{2}{*}{ Application } \\
\hline & & 1 & 2 & 3 & \\
\hline 1 & $\begin{array}{l}\text { Compact acrylic binder } \\
\text { Pigment paste } \\
\text { Water (Control) or nanocomposite } \\
\text { dispersions }(\mathrm{L} 1, \mathrm{~L} 2, \mathrm{~L} 3, \mathrm{~L} 4)\end{array}$ & $\begin{array}{l}250 \\
110 \\
640\end{array}$ & & & $\begin{array}{l}\text { Layer } 1 \text { : } \\
2 \times \text { sprays, free drying, } \\
\text { ironing at } 50^{\circ} \mathrm{C} \text { and } 100 \mathrm{~atm}\end{array}$ \\
\hline 2 & $\begin{array}{l}\text { Compact acrylic binder } \\
\text { Pigment paste } \\
\text { Water (Control) or nanocomposite } \\
\text { dispersions }(\mathrm{L} 1, \mathrm{~L} 2, \mathrm{~L} 3, \mathrm{~L} 4) \\
\end{array}$ & & $\begin{array}{l}250 \\
110 \\
640\end{array}$ & & $\begin{array}{c}\text { Layer } 2: \\
2 \times \text { sprays, free drying }\end{array}$ \\
\hline 3 & $\begin{array}{l}\text { Nitrocellulose based emulsion } \\
\text { Water (Control) or nanocomposite } \\
\text { dispersions (L1, L2, L3, L4) }\end{array}$ & & & $\begin{array}{l}700 \\
300\end{array}$ & $\begin{array}{l}\text { Layer 3: } \\
2 \times \text { sprays, free drying, } \\
\text { ironing at } 50^{\circ} \mathrm{C} \text { and } 100 \mathrm{~atm}\end{array}$ \\
\hline
\end{tabular}

functionalized textiles treated in different experimental variants is shown in figure $1, a$.

\section{Functionalization of leather materials}

Nanocomposite dispersions (table 1) based on $\mathrm{SiO}_{2} /$ $\mathrm{TiO}_{2} /$ poly(2,2'-bitiophene) were mixed by ultrasound for 10 minutes in acrylic film forming polymers for base coat layer and in nitrocellulose emulsion for top coat layer and they were applied by spraying in classical technology for leather surface finishing (table 3 ). The concentration of nanopowders on leather surface was of $0.04 \mathrm{mg} / \mathrm{cm}^{2}$. The new leather surfaces (L1, L2, L3 and L4) were smooth and comparable with classical treated leathers (figure $1, b$ ).

\section{Methods}

\section{Characterization of nanocomposite dispersions}

The characterisation of $\mathrm{SiO}_{2} / \mathrm{TiO}_{2} /$ poly $(2,2$ '-bitiophene) based nanocomposite dispersions was carried out for conductivity properties using a conductometer C1010 from Consort Belgium, with 1-100 $\mathrm{mS} / \mathrm{cm}$ scale and for particle size, polydispersity and Zeta potential characteristics with Zetasizer Nano-ZS from Malvern.

\section{Characterization of functionalized textile and leather materials}

\section{Physical-mechanical and physical-chemical} characteristics

The finished fabrics were characterized in terms of physical-mechanical characteristics, respectively: mass (SR EN 12127-2003), thickness (SR EN ISO 5084:2001), hydrophilicity by determining the wettability (drop test method according with SR 12751/ 1989 standard). Leather surfaces were characterized by water drop contact angle measurement (VGA Optima XE device), for abrasion resistance (SR EN ISO 13520-2003) and rubbing fastness (SR EN ISO 11640-2013).

\section{Scanning Electron Microscopy (SEM)}

The surface morphology of the treated samples was investigated by a FEI Quanta 200 Scanning Electron
Microscope with a GSED detector, at $8000 \times$ magnification and accelerating voltage of $12.5 \mathrm{kV}-20 \mathrm{kV}$. Surface resistivity measurement

Surface resistivity was measured according to SR EN 1149-1:2006 (EN 1149-1:2006) by using the ohmmeter PRS 801, with a potential difference of $100 \pm 5 \mathrm{~V}$ for $15 \pm 1 \mathrm{~s}$. Five measurements of the surface resistivity of each textile or leather sample were measured, and their average values were recorded.

\section{Photocatalytic properties}

Photocatalytic activity of treated samples was evaluated qualitatively by determining the photo degradation efficiency of methylene blue dye used as aqueous solution. Textile and leather materials treated with each type of nanocomposites were cut into $2 \times 2$ $\mathrm{cm}$ pieces and stained with $10 \mu \mathrm{l}$ of 15 ppm methylene blue solution. Subsequently, the samples have been subjected to visible irradiation with a halogen lamp $\left(500 \mathrm{~W}, 8 \mathrm{~mW} / \mathrm{cm}^{2}\right)$ for 30 minutes. Evaluation of the photocatalytic activity was performed by measuring the color difference of the irradiated samples compared with non-irradiated samples (reference). Color measurements were performed according to ISO 105 J03:2001, using the Datacolor ${ }^{\mathrm{TM}} 650$ Spectrophotometer (Datacolor, Switzerland) and the light source was the illuminant D65/10. Values obtained for chromatic parameters ( $D L^{*}$ - difference of lightness) are the average of 5 individual measurements carried out in different points on the same sample.

\section{RESULTS AND DISCUSSION}

\section{Nanocomposites characterisation}

The conductivity, particle size, polydispersity and Zeta potential of $\mathrm{SiO}_{2} / \mathrm{TiO}_{2} /$ poly(2,2'-bitiophene) based nanocomposite dispersions are presented in table 4 and show that the conductivity properties are similar with values from 18.7 to $22.2 \mu \mathrm{S} / \mathrm{cm}$ and the average particle sizes are lower for $\mathrm{PBTh}-\mathrm{TiO}_{2} / 1$ composite with best value for polydispersity. The most 


\begin{tabular}{|c|c|c|c|c|c|}
\hline \multicolumn{6}{|c|}{ NANOCOMPOSITE DISPERSIONS CHARACTERISATION } \\
\hline No. & Sample & $\begin{array}{c}\text { Conductivity } \\
(\mu \mathrm{S} / \mathrm{cm})\end{array}$ & $\begin{array}{l}\text { Average particle } \\
\text { size }(\mathrm{nm})\end{array}$ & $\begin{array}{c}\text { Polydispersity } \\
\text { PDI }\end{array}$ & $\begin{array}{c}\text { Zeta potential } \\
(\mathrm{mV})\end{array}$ \\
\hline 1 & PBTh- $\mathrm{TiO}_{2} / 0.5$ & 21.6 & 787.4 & 0.470 & -23.1 \\
\hline 2 & $\mathrm{PBTh}^{-\mathrm{TiO}_{2} / 1}$ & 22.2 & 297.2 & 0.230 & -24.8 \\
\hline 3 & PBTh-SiO $2 / 0.5$ & 19.4 & 708.9 & 0.455 & -30.8 \\
\hline 4 & $\mathrm{PBTh}_{-} \mathrm{SiO}_{2} / 1$ & 18.7 & 785.3 & 0.477 & -34.9 \\
\hline
\end{tabular}
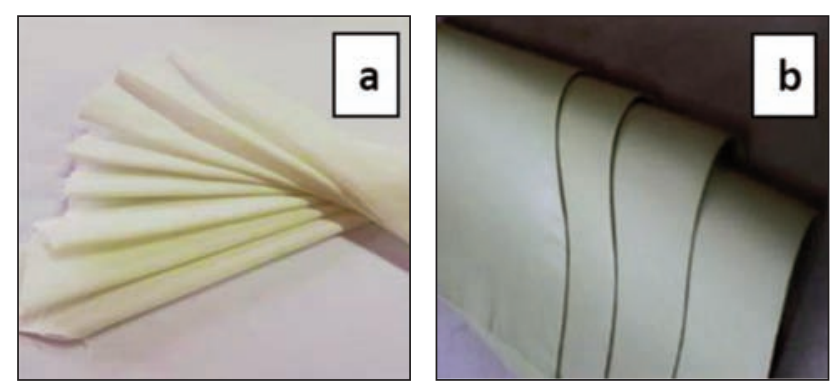

Fig. 1. Ilustrations of functionalized samples: $a$ - textile materials; $b$ - leathers

stable dispersions were PBTh- $\mathrm{SiO}_{2} / 1$ and PBTh$\mathrm{SiO}_{2} / 0.5$ with Zeta potential of -34.8 to $-30.8 \mathrm{mV}$.

\section{Textile and leather materials characterisation}

Scanning Electron Microscopy analyses confirm the low concentration and good dispersion of nanoparticles on materials surfaces, with clusters of around $2 \mu \mathrm{m}$ (figure 2).

\section{Surface resistivity}

Surface resistivity measurements allowed the selection of nanocomposite and technology for textile and leather treatment in order to increase conductivity. Analyzing the obtained results for functionalized textile materials it can be observed that the sample treated with $\mathrm{PBTh}-\mathrm{SiO}_{2} / 1$ nanocomposite and Itobinder $A G$ (code $3 V_{2}$ ) has the lowest resistivity (figure $3, a$ ). Leather surface shows lowest resistivity when is treated with $\mathrm{PBTh}-\mathrm{SiO}_{2} / 0.5$ nanocomposite (figure $3, b$ ), confirming the conductive properties of silica for both materials. The results showed lower resistivity values for textiles $\left(3 \mathrm{~V}_{2}\right)$ as compared to leather surface (L2). If we compare with literature data which show that the electrical resistivity of leather is lower by more than two orders of magni tude $\left(10^{2} \Omega\right)$ than of textile [12], we can conclude that the treatment with new nanocomposites makes the two materials similar in terms of electric properties.

Physical-mechanical and physical-chemical characteristics

\section{Hydrophilicity}

Water affinity of textile and leather treated surfaces was evaluated and showed no modification for textile materials and hydrophobic properties development on treated leather surface. In the case of textile materials the hydrophilicity does not show significant

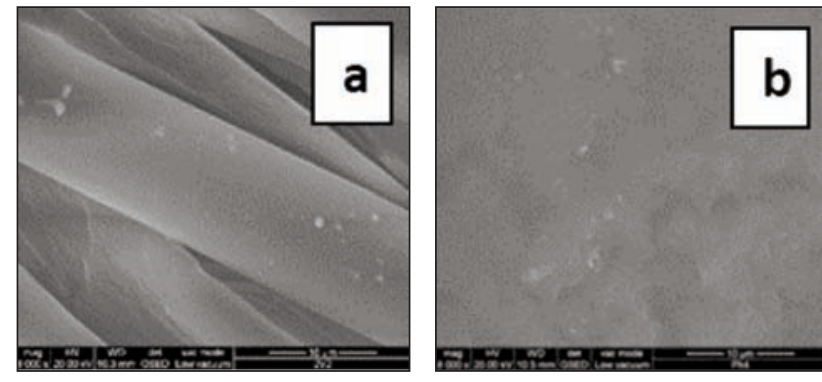

Fig. 2. SEM image at $8000 \times$ magnification for: $a$ - textile material, $b$ - leather material
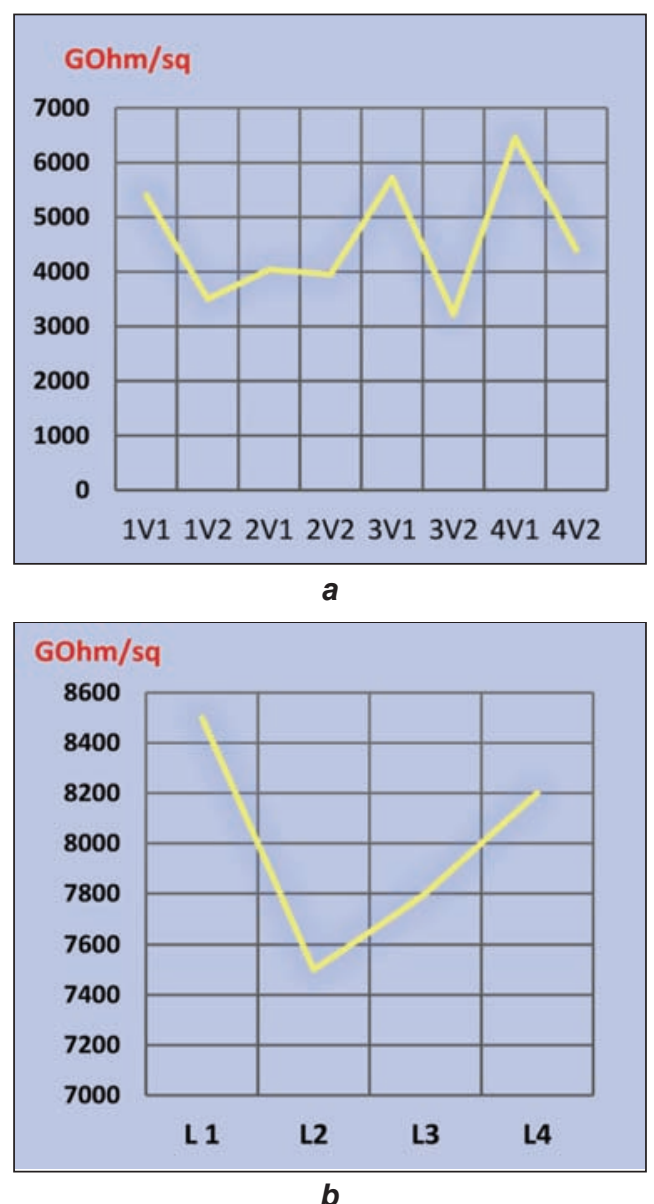

Fig. 3. Surface resistivity for: $a$ - textile materials, $b$ - leathers

changes after finishing treatments, just small variations (decreases) in compared to the untreated fabric, but these variations can be considered negligible. In the case of textiles samples, slightly lower values 
Table 5

PHYSICAL-MECANICAL AND PHYSICAL-CHEMICAL CHARACTERISTICS

\begin{tabular}{|c|c|c|c|}
\hline Sample & $\begin{array}{c}\text { Mass } \\
\left(\mathbf{g} / \mathbf{m}^{\mathbf{2}}\right)\end{array}$ & $\begin{array}{c}\text { Thickness } \\
(\mathbf{m m})\end{array}$ & $\begin{array}{c}\text { Hydrophilicity } \\
\mathbf{( s )}\end{array}$ \\
\hline 1V1 & 229 & 0.522 & $3-4$ \\
\hline 1V2 & 244 & 0.560 & 5 \\
\hline 2V1 & 220 & 0.490 & $3-4$ \\
\hline 2V2 & 243 & 0.530 & 5 \\
\hline 3V1 & 220 & 0.490 & $3-4$ \\
\hline 3V2 & 237 & 0.547 & 5 \\
\hline 4V1 & 230 & 0.480 & $3-4$ \\
\hline 4V2 & 243 & 0.528 & 5 \\
\hline M & 218 & 0.495 & 4 \\
\hline
\end{tabular}

of hydrophilicity are obtained for the fabrics treated in concomitant phase with dispersions based on PBTh- $\mathrm{TiO}_{2}$ or PBTh-SiO ${ }_{2}$ nanocomposites and with Itobinder AG, for which a wettability of 5 seconds has been obtained (table 5).

The modification of water drop contact angle on leather surface, from $48.1^{\circ}$ for classical finished leather to $90.5^{\circ}$ for $\mathrm{L} 2$ sample, $95.4^{\circ}$ for $\mathrm{L} 1,99.6^{\circ}$ for $\mathrm{L} 3$ and $105.5^{\circ}$ for L4 shows that hydrophobic properties can be developed by the treatment with new hybrid nanocomposites.

\section{Mechanical properties}

Analyzing the results obtained for $50 \%$ cotton $/ 50 \%$ polyester fabric treated in different variants with $\mathrm{PBTh}-\mathrm{TiO}_{2}$ or $\mathrm{PBTh}-\mathrm{SiO}_{2}$ nanocomposites (table 5), it can be observed that, during the finishing process, fabric contraction took place, leading to the increasing of mass $\left(\mathrm{g} / \mathrm{m}^{2}\right)$ and thickness $(\mathrm{mm})$ compared to the untreated fabric $(\mathrm{M})$, without significant differences between variants. This behaviour is normal for the finishing processes of cotton or blended fabrics carried out in aqueous medium and high temperatures. Also, the increase of these characteristics can also be caused by the additions of functionalization agents (nanocomposites and binder) that remain attached to the textile fabrics at the end of the process.

The abrasion resistances of $L 2, L 3$ and $L 4$ leather surfaces treated with new nanocomposites were good up to 51,200 revolutions as compared to the classical finished leather and L1 surface with resistances up to 25,600 revolutions. The rubbing test results showed good results up to 75 dry and wet rubbing cycles and up to 50 rubbing cycles with perspiration solution for sample L2 as compared to control and L1, L3 and L4 samples with lower performances.

\section{Photocatalytic properties of treated textile and leather surfaces}

Photocatalytic properties of textile materials have been assessed only for the samples treated with $\mathrm{PBTh}-\mathrm{TiO}_{2}$ nanocomposites. Photodegradation efficiency of functionalized textile materials stained with methylene blue solution varies depending on the quantity of $\mathrm{TiO}_{2}$ nanoparticles from nanocomposite dispersions, the best self-cleaning properties being obtained for sample treated with dispersion based on PBTh- $\mathrm{TiO}_{2} / 0.5\left(1 \mathrm{~V}_{1}\right)$ after 30 minutes of irradiation, the value of the lightness difference $\left(\mathrm{DL}^{*}\right)$ obtained for this sample having positive values, higher with 3 absolute units in comparison with the non-irradiated sample (figure 4,a).

Leather surfaces showed photocatalytic properties (figure $4, b$ ) with greater rates of organic stain decomposition than $119 \%$ (12.8 absolute units) for leather surface treated with $\mathrm{PBTh}-\mathrm{TiO}_{2} / 1$ (L3) and of $80.6 \%$ (10.7 absolute units) for leather treated with PBTh$\mathrm{SiO}_{2} / 0.5$ (L2), after 30 minutes of exposure to visible light, as compared to classical finished leather surface.
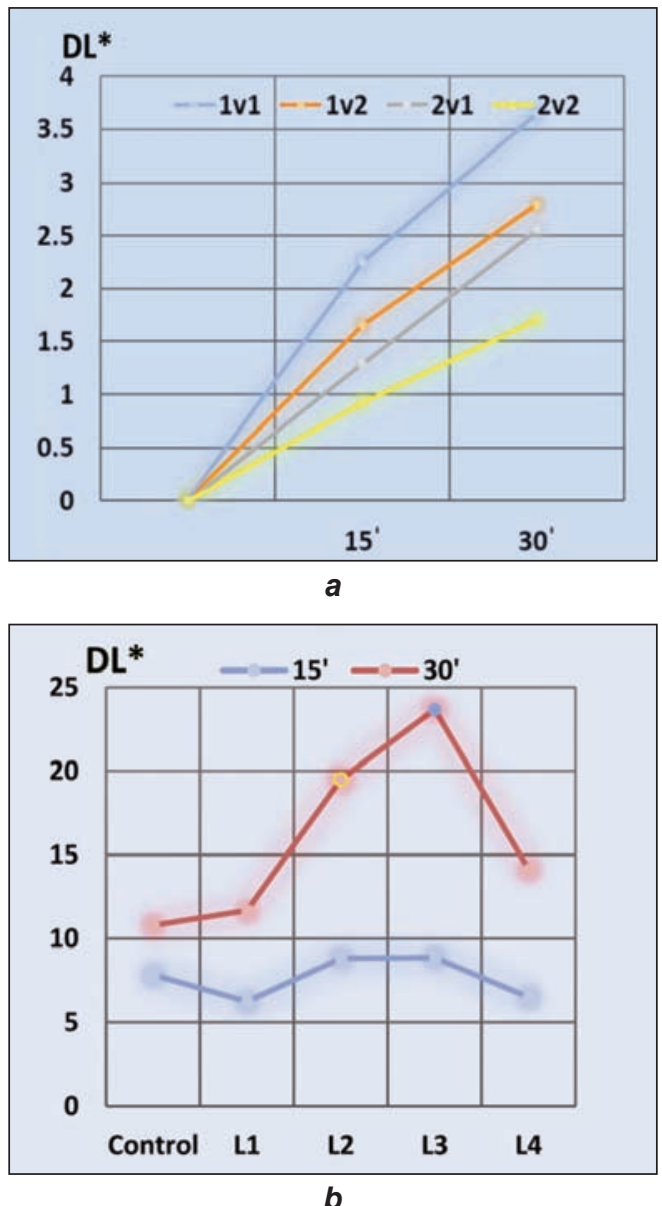

Fig. 4. Photocatalytic properties of: $a$ - textile materials, $b$ - leather surfaces

\section{CONCLUSIONS}

New hybrid $\mathrm{SiO}_{2} / \mathrm{TiO}_{2} /$ poly(2,2'-bitiophene) based nanocomposites with two concentrations of $\mathrm{TiO}_{2}$ and $\mathrm{SiO}_{2}$ nanoparticles were used for $50 \%$ cotton/50\% polyester fabrics and sheep skin leather treatment in view of multifunctional surface properties development. Textile materials treated with dispersion based on PBTh-SiO $/ 1$ nanocomposite and Itobinder AG showed lower resistivity. Mechanical properties of functionalized textile materials do not show significant changes after finishing treatments as compared 
to untreated fabric. The cotton/polyester fabric treated with $\mathrm{PBTh}-\mathrm{TiO}_{2} / 0.5$ nanocomposite showed a higher photodegradation stain efficiency.

Leather surface finished with $\mathrm{PBTh}-\mathrm{SiO}_{2} / 0.5$ nanocomposite showed lowest resistivity as compared to other nanocomposites, hydrophobic and photocatalytic properties in visible light against methylene blue stain. Leather surface treated with PBTh- $\mathrm{TiO}_{2} / 1$ nanocomposite revealed more hydrophobic characteristics and best photocatalytic rate of methylene blue stain decomposition. The research on the potential of new hybrid nanocomposites based on $\mathrm{SiO}_{2} / \mathrm{TiO}_{2} /$ poly(2,2'-bitiophene) for multifunctional properties development on textile materials and leather surfaces is in progress.

\section{ACKNOWLEDGEMENTS}

This work was supported by a grant of the Romanian Ministry of Research and Innovation, CCCDI - UEFISCDI, project number PN-III-P1-1.2-PCCDI-2017-0743/ contract 44/2018, Project 3, within PNCDI III.

\section{BIBLIOGRAPHY}

[1] Gashti, M.P., Pakdel, E., Alimohammadi, F. Nanotechnology-based coating techniques for smart textiles, In: Active Coatings for Smart Textiles, 2016, pp. 243-268.

[2] Kaygusuz, M. K., Meyer, M., Aslan, A. The effect of $\mathrm{TiO}_{2}-\mathrm{SiO}_{2}$ nanocomposite on the performance characteristics of leather, In: Materials Research, 2017, vol. 20, no 4, pp. 1103-1110.

[3] Maestre-López, M.I., Payà-Nohales, F., Cuesta-Garrote, N., Arán-Ais, F., Martínez-Sánchez, M.A., Orgilés-Barceló, C., Bertazzo, M. Antimicrobial effect of coated leather based on silver nanoparticles and nanocomposites: synthesis, characterisation and microbiological evaluation, In: Journal of Biotechnology \& Biomaterials, 2015, vol. 5, pp. 171-181.

[4] Gowri, S., Almeida, L., Amorim, T., Carneiro, N., Souto, A. P., Esteves, M. F. Polymer nanocomposites for multifunctional finishing of textiles - a review, In: Textile Research Journal, 2010, vol. 80, pp. 1290-1306.

[5] O'Leary, D. Conductive leather materials and methods for making the same, US 8,507,102 B1, 2013, pp. 1-11.

[6] Baibarac, M., Baltog, L., Lefrant, S. Raman spectroscopic evidence for interfacial interactions in poly(bithiophene)/single-walled carbon nanotube composites, In: Carbon, 2009, vol. 47, pp. 1389-1398.

[7] Akerfeldt, M., Straat, Walkenstrom, P. Electrically conductive textile coating with a PEDOT-PSS dispersion and a polyurethane binder, In: Textile Research Journal, 2013, vol. 83, no 6, pp. 618-627.

[8] Wegene, J.D., Thanikaivelan, P. Conducting leathers for smart product applications, In: Industrial\&Engineering Chemistry Research, 2014, vol. 53, pp. 18209-18215.

[9] Erdogan, M.K., Karakisla, M., Sacak, M. Conductive polyaniline-polythiophene/poly(ethylene terephthalate) composite fiber: effects of $\mathrm{pH}$ and washing processes on surface resistivity, In: Journal of Applied Polymer Science, 2015, vol. 132, no 20, pp. 41979-41988.

[10] Dashti, M., Mokhtari, J., Nouri, M., Shirini, F. Imparting conductivity and chromic behavior on polyester fibers by means of poly(3-methylthiophene) nanocoating, In: Journal of Applied Polymer Science, 2011, vol. 124, no 4, pp. 3007-3012.

[11] Erdogan, M.K., Karakisla, M., Sacak, M. Preparation, characterization and electromagnetic shielding effectiveness of conductive polythiophene/poly(ethylene terephthalate) composite fibers, In: Journal of Macromolecular Science Part A-Pure And Applied Chemistry, 2012, vol. 49, no 6, pp. 473-482.

[12] Jankauskaitè, V., Gulbinienè, A., Kondratas, A., Domskienè, J., Urbelis, V. Influence of the structure of footwear upper and lining materials on their electrical properties, In: Fibres\&Textiles in Eastern Europe, 2018, vol. 26, pp. 7-92.

[13] Yuce, I., Yukseloglu, M., Canoglu, S. An analysis of conductive fibers as smart textiles, In: Annals of the University of Oradea. Fascicle of Textiles, Leatherwork, 2018, vol. 19, no 2, pp. 105-110.

\section{Authors:}

\section{LAURA CHIRILA ${ }^{1}$, CARMEN GAIDAU ${ }^{2}$, MALVINA STROE ${ }^{3}$, MIHAELA BAIBARAC ${ }^{3}$, MARIA STANCA ${ }^{2}$, DENISA MARIA RĂDULESCU ${ }^{1}$, DIANA ELENA RĂDULESCU ${ }^{1}$, COSMIN-ANDREI ALEXE $^{2}$}

${ }^{1}$ The Research-Development National Institute for Textile and Leather, 16, Lucretiu Patrascanu Street, Bucharest, 030508, Romania

${ }^{2}$ The Research-Development National Institute for Textile and Leather, Leather and Footwear Research Institute (ICPI) Division, 93, Ion Minulescu Street, Bucharest, 031215, Romania

${ }^{3}$ National Institute of Materials Physics - Romania Atomistilor Street 405 A, barac@infim.ro

\section{Corresponding author:}

\section{LAURA CHIRILA}

e-mail: laura.chirila@certex.ro

CARMEN GAIDAU

e-mail: carmen_gaidau@hotmail.com 


\section{The use of collagen-coated polypropylene meshes for nasal reconstructive surgery}

DOI: $10.35530 / I T .070 .03 .1680$

MIHAI-ALEXANDRU PĂUN

ADRIAN FRUNZĂ

ELENA-LUMINITTA STĂNCIULESCU

TIBERIU-CIPRIAN MUNTEANU

ALEXANDRU CHIOTOROIU

IOAN CRISTESCU

SABINA GRAMA

ALEXANDRA ENE

CARMEN MIHA

REZUMAT - ABSTRACT

Utilizarea plaselor din polipropilenă acoperite cu colagen pentru chirurgia reconstructivă nazală

Chirurgia reconstructivă a peretelui abdominal și toracic utilizează frecvent diverse materiale pentru a repara defectele mari. Plasele din polipropilenă sunt un exemplu. În chirurgia reconstructivă nazală sunt rar folosite pentru restaurarea cartilajelor.

Scopul acestui studiu este de a demonstra utilitatea plaselor din polipropilenă acoperite cu colagen în chirurgia reconstructivă nazală, deoarece acestea sunt materiale ușor de utilizat, cu o incidență redusă a reacțiilor la corpul străin și cu un preț foarte mic comparativ cu al altor produse.

A fost efectuat un studiu privind utilizarea plaselor din polipropilenă acoperite cu colagen, care include, de asemenea, o comparație cu alte tipuri de materiale utilizate pentru reconstrucția cartilajului nazal. Mai mult, a fost efectuat un studiu retrospectiv asupra pacienților spitalizați în Departamentul de Chirurgie Plastică al Spitalului Clinic de Urgență din București.

Cea mai bună opțiune și, în același timp, standardul de aur pentru reconstrucția cartilajului nazal este considerat a fi transplantul de cartilaj autolog. În clinica noastră am observat rezultate bune atunci când s-au utilizat grefe de cartilaj autolog septal sau auricular.

Polipropilena este rar utilizată în chirurgia reconstructivă nazală, fiind efectuat, până în prezent, un număr restrâns studii privind beneficiile și dezavantajele acestei materii prime la fabricarea de dispozitive medicale pentru implanturi nazale. Plasele din polipropilenă sunt utilizate pe scară largă în reconstrucția peretelui abdominal și în chirurgia pentru prolapsul organelor pelvine. În acest domeniu chirurgical, se utilizează și plasele din polipropilenă acoperite cu colagen, însă studiile viitoare vor demonstra dacă acestea sunt suficient de eficiente și în chirurgia reconstructivă nazală.

Cuvinte-cheie: plase, colagen, cartilaj nazal, chirurgie reconstructivă

\section{The use of collagen-coated polypropylene meshes for nasal reconstructive surgery}

Reconstructive surgery of the abdominal and thoracic wall frequently utilizes various materials in order to repair large defects. Polypropylene meshes are an example. In nasal reconstructive surgery they are rarely used for cartilage restoration.

The purpose of this paper is to demonstrate the utility of the collagen-coated polypropylene meshes in nasal reconstructive surgery, as they are easy-to-use materials, with reduced incidence of foreign body reactions and with a very small price compared with other compounds.

We conducted a literature review on the usage of the collagen-coated polypropylene meshes which also includes a comparison with other types of materials applied for nasal cartilage reconstruction. Moreover, we performed a retrospective study, on the patients hospitalized in the Plastic Surgery Department of the Clinical Emergency Hospital, Bucharest. The best option and in the same time the gold standard for nasal cartilage reconstruction is considered to be autologous cartilage transplantation. In our clinic we observed good results when autologous septalor auricular cartilage grafts were used.

Polypropylene is seldom used in nasal reconstructive surgery, having been conducted so far, a limited number of studies related to benefits and disadvantages of this type of material in the accomplishment of the medical devices used as a nasal implant. Polypropylene meshes are largely used in abdominal wall reconstruction and in the surgery for pelvic organ prolapse. In this surgical field, collagen-coated polypropylene meshes are also used, but future studies will demonstrate if they are effective enough in the nasal reconstructive surgery as well.

Keywords: nets, collagen, nasal cartilage, reconstructive surgery

\section{INTRODUCTION}

Nasal cartilage reconstruction still remains a challenge for every plastic surgeon. The nose, an aesthetic unit of the face, located central, has a great aesthetic value for patient's life quality with a considerable social impact. Furthermore, it has its own respiratory and phonetic roles [1].
Nasal reconstruction is performed in several phases, depending on the type of defect. It is important to take into consideration the anatomical features of the nose with the purpose of restoring the cutaneous, cartilaginous and osseous layers, but also the nasal mucosa in order to preserve the functionality and to create an appearance as close as possible to the patients' expectations [1]. 
Nasal cartilage reconstruction can be achieved with using autologous or allogenic grafts, either synthetic or biologic. For abdominal or thoracic wall reconstruction, polypropylene meshes are largely used currently while there are also numerous studies regarding the use of collagen-coated polypropylene meshes in this type of surgery [1].

\section{THE PURPOSE OF THE STUDY}

The purpose of this literature review is to demonstrate the adequacy of collagen-coated polypropylene meshes in nasal reconstructive surgery, as they are easy-to-use materials, with reduced incidence of foreign body reactions and with a very small price compared with other compounds.

Moreover, we performed a retrospective study, on the patients hospitalized in the Plastic Surgery Department of the Emergency Clinical Hospital, Bucharest, in order to establish the feasibility of alternative methods such as the reconstruction with allogenic materials.

\section{MATERIALS AND METHODS}

We conducted a review of the relevant literature on the use of collagen-coated polypropylene meshes for nasal cartilage reconstruction and includes as well a comparison between this type of material and others. Each compound is studied in terms of its structure, purpose/indications and possible complications.

The retrospective study was conducted on 110 patients from the Clinical Emergency Hospital Bucharest, department of Plastic Surgery and Reconstructive Microsurgery over the period 2012-2013.

We applied simple correlations to the factors involved in the study, followed by outlining the significant results. Thereafter, the results were statistically analysedand explained in the charts and tables below.

\section{RESULTS}

\section{Biomaterials}

Biomaterial is a term used for describing a substitute of different tissues or a tissue defect enhancer, being either a natural or a synthetic substance with the aim of making a diagnostic or a treatment [2-3].

Macroscopic properties of an ideal biomaterial are: to be compatible with the tissue that will eventually be replaced, to be nonresorbable over time, not to migrate from the original implantation site, to be easily removed in case of complications such as infections or necrosis, to be cheap [3]. The ideal biomaterial should be flexible and readily accessible [4], resistant to sterilisation and infection [5], unable to pass on any disease, non-carcinogenic, biocompatible. In addition, the foreign body reaction and surface contamination should be minimum [6].

Nasal reconstruction requires, besides the aesthetic aspect, the improvement of functionality, thus maximising results. The biomaterials used in nasal reconstruction should provide a natural, aesthetic result, therefore increasing patient's satisfaction [2].
The implants used for nasal reconstruction

In order to be used as a replacement for nasal cartilage, biomaterials should have several specific properties. The functionality and the aesthetic aspect of this face unit are paramount, with a tremendous emotional impact on the patient, affecting his life quality in a significant manner.

The meshes allow to be embedded in the surrounding tissues, can be easily reshaped, are more smoothly inserted at their predefined location and reduce the infectious risk. Their pores can have various sizes and their composition is adapted as to be compatible with the host $[1,7]$.

\section{Autologous cartilage}

Autologous cartilage is the ideal cartilage to use for nasal reconstruction, as currently indicated by the

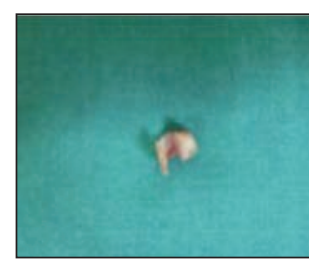

Fig. 1. Auricular cartilage [1] relevant literature figure 1 [1]. They also have some disadvantages, owing to the donor site morbidity, the limited amount of tissue and the rise in surgical time [8].

Autologous cartilage is most frequently harvested form the nasal septum, the auricle and the rib [9]. The nasal septum graft is preferred if there is enough tissue to be harvested, because it shares the same location with the initial/nasal surgical field and due to its resemblance with the adjacent nasal cartilages [2].

\section{Alloplastic materials}

The silicone (polydimethylsiloxane) was widely used in the past for facial reconstruction such as for augmentation of dorsum nasi, but with progressively fewer indications in present. Unfortunately, it creates a dead space between the implant and the surrounding tissues, it gets more easily infected and has a greater risk of extrusion, migration, calcification and inflammation [10].

The silicone is found in a liquid or gel state and as rubber [11]. The former is responsible for a cellular response similar to the foreign body reaction (giant cells with silicone inclusions, surrounded by neutrophils, plasmocytic and lymphocytes) [12].

Polypropylene nets (eg. POLYPROPYLENE MESH) are widely used in the abdominal and thoracic wall reconstruction surgery, but there are few studies concerning their use in nasal cartilage reconstruction [13].

These are nonresorbable materials that trigger a minimal and self-limited inflammatory reaction, embedding the mesh into the surrounding tissue [14]. The polypropylene is also used for utero-vaginal reconstruction, facial reconstruction and for several endoscopic procedures [14].

Dacron (polyethylene terephthalate (PET)) is used in general surgery for hernia repair, as suture material, as vascular prosthesis, in thoracic wall reconstruction and for chin and nose augmentation. It is biocompatible, flexible and nonresorbable[15]. 
Mersilene (polyethylene terephthalate) is used in reconstructive surgery and as part of arterial prostheses as well. PET is used in abdominal and thoracic wall reconstruction, but also for genioplasty - facial augmentation [16], head and neck surgery [17]. In addition, it is used for dorsum nasi augmentation [18]. Mersilene was mostly abandoned in favor of Gore-tex SAM (subcutaneous augmentation material) [2]. So far, it has proven to have good aesthetic results for temporal fossa reconstruction and few complications, including implant extrusion or exposure and infection. Moreover it is cheap, it can be easily folded and it restores the defect to its natural appearance [19].

Medpor (high-density porous polyethylene) is biocompatible, nonresorbable, resistant to stress [20], it allows osseous and soft tissues growth, has a small rate of infection and generates few foreign body reactions [21]. The most frequent complications quoted in the relevant literature regarding this type of mesh are: lateral displacement of the implant, fistula or abscess formation, implant extrusion and infection. $[1,22]$. Medpor is used for malar and chin augmentation [23].

Polytetrafluoroethylene (Teflon, Gore-Tex) is used in facial reconstruction, rhinoplasty or dorsum nasi augmentation [2]. PTFE creates a fibrous tissue layer attached to the bone, but does not ensure structural support [24] and can also induce a foreign body reaction [5]. Gore-Tex is extensively used in vascular surgery [25], for chin augmentation and in corrective rhinoplasty [26] with an impressive biocompatibility [25]. Gore-Tex is employed with excellent results by general and vascular surgery [18]. It generates a rather modest host immune response, has good biocompatibility with reasonable costs [27]. Gore-Tex is used to manage a wide variety of nasal defects with exceptional results [28].

\section{Biological materials}

\section{Collagen}

The collagen is a structural protein found in animals [29]. Its structural unit is called triple helix [29].

The materials produced using collagen triple-helices elongated fibrils are currently widely used throughout the biomedical science and nanotechnologies [29].

\section{Regenerative medicine and nasal cartilage reconstruction}

Regenerative medicine makes use of biomaterials, growth factors and stem cells in order to repair, replace or regenerate tissues and organs [9]. Currently, tissue engineering is headed towards developing implantable biohybrids formed from biodegradable matrices in combination with in vitro cell cultures as a regenerative strategy [30].

Autologous cartilage grafts obtained from tissue engineering allow the safe reconstruction of the alar lobule with excellent functional results [31].
The retrospective study

The retrospective study took into account 18 factors and measured the incidence of each one.

It is important to determine the adequacy of alloplastic materials for nasal cartilage reconstruction.

Table 1

THE INCIDENCE OF THE ANALYSED FACTORS IN PATIENTS WITH POSTTRAUMATIC OR POSTEXCISIONAL NASAL DEFECTS [1]

\begin{tabular}{|l|l|c|c|}
\hline \multirow{2}{*}{ Factor } & \multicolumn{1}{|c|}{ Type of factor } & $\begin{array}{c}\text { No. of } \\
\text { cases }\end{array}$ & $\%$ cases \\
\hline \multirow{5}{*}{$\begin{array}{l}\text { Type of } \\
\text { reconstruction }\end{array}$} & $\begin{array}{l}\text { Closure by } \\
\text { secondary intention }\end{array}$ & 10 & 9,09 \\
\cline { 2 - 4 } & Primary suture & 56 & 50,9 \\
\cline { 2 - 4 } & Graft STSG + FTSG & 8 & 7,26 \\
\cline { 2 - 4 } & Various flaps & 7 & 6,35 \\
\cline { 2 - 4 } & Nasogenianflap & 14 & 12,72 \\
\cline { 2 - 4 } & Free transfer & 3 & 2,72 \\
\cline { 2 - 4 } & Other flaps & 8 & 7,25 \\
\cline { 2 - 4 } & Total rhinoplasty & 3 & 2,72 \\
\cline { 2 - 4 } & Koenig graft & 1 & 0,90 \\
\hline \multirow{4}{*}{ Complications } & Yes & 9 & 8,18 \\
\cline { 2 - 4 } & No & 101 & 91,81 \\
\hline \multirow{2}{*}{ Comorbidities } & Yes & 29 & 26,36 \\
\cline { 2 - 4 } & No & 81 & 73,63 \\
\hline \multirow{3}{*}{$\begin{array}{l}\text { Defect depth } \\
\text { lesions }\end{array}$} & $\begin{array}{l}\text { Tegument and } \\
\text { subcutaneous tissue }\end{array}$ & 79 & 71,81 \\
\cline { 2 - 4 } & Cartilage damage & 7 & 6,36 \\
\cline { 2 - 4 } & Nasal bones & 24 & 21,81 \\
\hline \multirow{2}{*}{\begin{tabular}{l} 
Concomitant \\
\cline { 2 - 4 }
\end{tabular}} & Yes & 32 & 29,09 \\
\hline
\end{tabular}

Posttraumatic and post excisional defects reconstruction depended on the type of defect, its location and other concomitant lesions in a statistically significant proportion. The emphasis was put on maximising the good results and minimising the postoperative complications thus increasing patient's satisfaction and improving their life quality.

Composite grafts with autologous cartilage in their structure were seldom used, in selected case. Only one Koenig graft $(0,90 \%)$ was used.

According to the figure 1 only 7 patients $(6.36 \%)$ had cartilage defects as well, which is a very small percentage from the total number of cases. Most of them were addressed by direct suture of the nasal cartilages (figures 2, 3).

\section{Polypropylene meshes and collagen-coated polypropylene meshes}

Yucebas K. et al used polypropylene meshes for nasal perforations in laboratory rabbits. This material generates a small amount of fibrosis and a limited foreign body reaction with a very high biocompatibility in nasal cartilage reconstruction [32]. Simple 


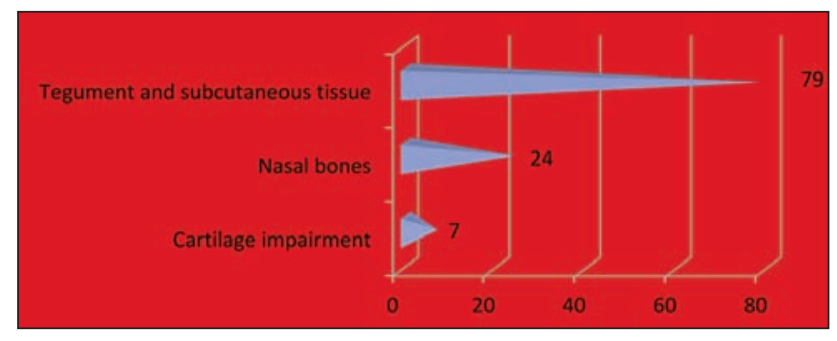

Fig. 2. Depth of the defect among included patients [1]

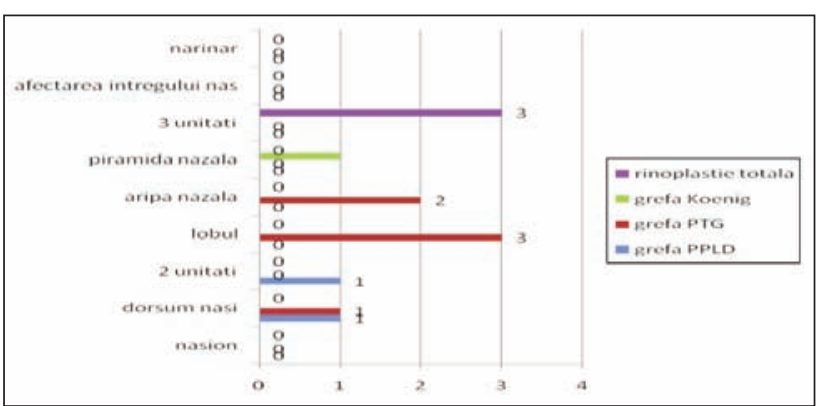

Fig. 3. Types of nasal reconstruction according to defect location [1]

polypropylene meshes and collagen coated-polypropylene meshes are used in abdominal wall reconstruction with impressive results [33].

Goulart F. et al. studied highly purified collagen-coated polypropylene meshes in rat models and demonstrated their capability to modulate angiogenesis and some immune metalloproteinase-mediated reactions at the implant site. These may be used for pelvic surgery [34], but also for nasal reconstructive surgery.

Collagen-coated polypropylene meshes implanted intraperitoneally, may reduce the risk of visceral adhesions. An experiment was performed using polypropylene meshes with a collagen coating. The collagen was extracted from laboratory rats using acetic acid. The results exceed expectations, with very few complications and a very good biocompatibility [35]. These meshes are used with a low incidence of adhesions and with an excellent biocompatibility for laparoscopic abdominal wall defects [36].

Polypropylene meshes provide good mechanical resistance and are largely used for abdominal wall defects and pelvic organ prolapse. The inflammatory response is diminished considerably if biological matrices are used, such as the ECM (extracellular matrix) hydrogel-coated polypropylene mesh [37]. The Proceed ventral patch used for umbilical hernia repair generates tissue adhesions which involve parts of the intestine, outnumbering the Perietex and Ventralex variants. Parietex and Ventralexon the other hand, will be covered in a mezothelial shell as a response to their presence, resulting in minimal formation of adhesions [38].

Fibroblast or mesenchymal stem cells (MSC) coated Parietex (polyester) mesh, SoftMesh (light-weight monofilament polypropylene), TIGR (polylactide composite mesh) or Strattice (porcine skin-derived collagen) are some types of mesh studied and used today. The cellular coverage of the mesh may influence the biocompatibility and may become a key aspect in refining their properties, figure 4 [39]. The meshes can also be coated with human dermalfibroblasts (HFs) or with normal rats'kidney (NRK) cells or with rat's mesenchymal stem cells (MSCs). These coated meshes, either synthetic or biologic, modulate the host immune response and therefore enhance their adaptability [40]

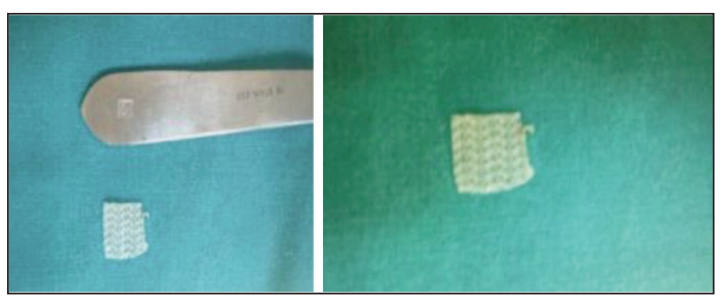

Fig. 4. Collagen-coated polypropylene mesh

\section{CONCLUSION}

The best option for nasal cartilage reconstruction is the use of autologous cartilage, which represents the gold-standard for nasal cartilage reconstruction. Regarding corrective rhinoplasty, where the amount of autologous cartilage is limited, the allogenic implants are employed/used with good results [41].

The silicone is used to augment dorsum nasi and the columella [41]. Porous high-density polyethylene (Medpor) may ensure an important structural support [41]. These implants are seldom used due to their high incidence of complications: implant extrusion or infection [42]. Medpor is also used in trauma surgery and not just in rhinoplasty [43]. Mersilene (polyethylene terephthalate) is used for volume correction in nasal reconstruction; though it cannot be used for structural support [44]. Gore-tex is most frequently used for chin augmentation [45], for dorsum nasi or lateral walls augmentation, premaxillary graft, lobule or supralobule [42].

Polypropylene is an affordable synthetic material, easy to implant, with a wide availability and flexibility, being found in different and numerous forms. Its use in nasal cartilage reconstruction is currently, a subject of great interest.

Collagen-covered polypropylene meshes are use nowadays internationally for abdominal and thoracic wall reconstructive surgery and for pelvic surgery. As a consequence, this material has the potential to be implemented in cartilage reconstruction as well.

As we have already noticed, there a too few patients in our clinic who need cartilage reconstruction which is usually achieved with only autologous auricular or septal cartilage graft. As such, the small number of cases and the possibility of autologous transplant obviate the necessity of alloplastic materials.

However, if we take into account the low incidence of complications at the donor site and the reduction in the time of surgery, particularly for patients in poor condition, we stress the need for future studies in 
order to establish the adequacy for the introduction of alloplastic materials in the current reconstructive techniques.

Polypropylene is rarely used in nasal reconstructive surgery with few studies on its benefits and disadvantages as a nasal implant. Polypropylene meshes are widely used in abdominal wall reconstruction and pelvic prolapse surgery [46]. Collagen-coated polypropylene meshes are used as well in these surgical fields, but future studies will determine if it can really be confirmed as a practical and durable solution in nasal reconstructive surgery.

\section{BIBLIOGRAPHY}

[1] Ionita, Sabina, Doctoral Thesis: Metode moderne de reconstructie a defectelor posttraumatice si postexcizionale ale nasului, 2015, UMF Carol Davila Bucuresti.

[2] Vuyk, H.D., Adamson, P.A. Biomaterials in rhinoplasty, In: Otolaryngol., 1998, 23, pp. 209-217.

[3] Buddy D. Ratner, Overview of biomaterials characterization, University of Washington Engineered Biomaterials (UWEB) Workshop, In Vitro Analyses of Cell/Scaffold Products, http://www.fda.gov/downloads/biologicsblood vaccines/newsevents/workshopsmeetingsconferences/ucm096092.pdf.

[4] Vuyk, H.D., Adamson, P.A. Biomaterials in Rhinoplasty. In: Clin. Otolaryngol., 1998; 23, pp. 209-217.

[5] Lipschitz, A.H., Kenkel, J.M. Implantation bone, cartilage, and alloplasts. In: Barton F.E. (ed.) - Selected readings in plastic surgery. Vol. 10(2), Dallas: Selected Readings in Plastic Surgery, 2004.

[6] Dresner, H.S., Hilger, P.A. An overview of nasal dorsal augmentation. In: SeminPlast Surg., 2008 May; 22(2):65-73.doi:10.1055/s-2008-1063566.

[7] Romo, T. 3rd, Pearson, J.M. Nasal implants. In: Facial PlastSurgClin N Am., 2008 Feb; 16(1), pp. 123-132.

[8] Romo, T. 3rd, Sclafani, A.P., Sabini, P. Use of porous high-density polyethylene in revision rhinoplasty and in the platyrrhine nose. In: Aesthetic Plast Surg., 1998 May-Jun; 22(3), pp. 211-221.

[9] Bularda, A.G., Chiotoroiu, A., Stănciulescu, E.L. Future directions in tissue repair using biomaterials. In: Industria Textilă, Volume 69, No. 4, 2018, 69, pp. 422-426.

[10] Yanaga, H., Koga, M., Imai, K., Yanaga, K. Clinical application of biotechnically cultured autologous chondrocytes as novel graft material for nasal augmentation. In: Aesthetic Plast Surg., 2004 Jul-Aug; 28(4), pp. 212-21.

[11] Gear, A.J., Lokeh, A., Aldridge, J.H., et al. Safety of titanium mesh for orbital reconstruction. In: Ann Plast Surg., 2002; 48:1-7; discussion 7-9.

[12] Brown, B.L., Neel, H.B. 3rd, Kern, E.B. Implants of Supramid, Proplast, Plasti-Pore, and Silastic. In: Arch Otolaryngol., 1979 Oct; 105(10), pp. 605-9.

[13] Rezistenta chimica a polipropilenei (PP), Buletin tehnic TC003, v1.1 (decembrie 2006), VALROM Industrie srl.

[14] Polipropilena, http://astramed.ro/plase-pentru-hernie/plase-pentru hernie?gclid=ClyJsZit-b4CFeoJwwodmUkA9A.

[15] Arnold S. Breitbart and Valerie J. Ablaza, grabb and smith's plastic surgery, Sixth edition by Charles H. Thorne., chapter 7 implant materials 2007, lippincottwilliams\&wilkins.

[16] Nguyen, P.N., Sullivan, P. Advances in the management of orbital fractures. In: ClinPlast Surg., 1992 Jan; 19(1), pp. 87-98.

[17] Ousterhout, D.K. Prosthetic forehead augmentation. In: Ousterhout DK (ed) - Aesthetic Contouring of the Craniofacial Skeleton. Boston, Little Brown, 1991; pp. 199-219.

[18] Lohuis, P.J.F.M., Watts, S.J., Vuyk, H.D. Augmentation of the nasal dorsum using Gore-Tex ${ }^{\circledR}$ : intermediate results of a retrospective analysis of experience in 66 patients. In: Clin. Otolaryngol., 2011; 26:214-217.doi: 10.1046/j.13652273.2001.00453.x

[19] Atherton, D.D., Joshi, N., Kirkpatrick, N. Augmentation of temporal fossa hollowing with Mersilene mesh. In: Journal of Plastic, Reconstructive \& Aesthetic Surgery, 2009;63(10):1629-34.doi: 10.1016/j.bjps.2009.09.022.

[20] Hunt, J., Salomon, J. Augmentation mammoplasty. In: Selected Read Plast Surg., 2002; 9(28), pp. 1-35.

[21] Mohammadi, S.H., Ghourchian, S.H., Izadi, F., Daneshi, A., Ahmadi, A. Porous high-density polyethylene in facial reconstruction and revision rhinoplasty: a prospective cohort study. In: Head Face Med., 2012; 8:17.

[22] Mohammadi, S., Mohseni, M., Eslami, M., Arabzadeh, H., Eslami, M. Use of porous high-density polyethylene grafts in open rhinoplasty: noinfectious complication seen in spreader and dorsal grafts. In: Head Face Med., 2014; 10:52.doi:10.1186/1746-160X-10-52.

[23] Niechajev, I. Facial reconstruction using porous high-density polyethylene (Medpor): long-term results. In: Aesthetic Plastic Surgery, 2012 August; 36(4), pp. 917-927.

[24] Brand, K.G., Johnson, K.H., Buoen, L.C. Foreign body tumorigenesis. In: CRC Crit Rev Toxicol., 1976; 4(4), pp. 353-394.

[25] Soyer, T., Lempinen, M., Cooper, P., Norton, L., Eiseman, B. A new venous prosthesis. In: Surgery, 1972; 72(6), pp. 864-872.

[26] Maas, C.S., Gnepp, D.R., Bumpous, J. Expanded polytetrafluoroethylene (Gore-Tex soft-tissue patch) in facial augmentation. In: Arch. Otolaryngol. Head Neck Surg., 1993; 119(9), pp. 1008-1014.

[27] Godin, M.S., Waedman, S.R., Johnson, C.M. Jr. Nasal augmentation using Gore-Tex. A 10-year experience. In: Arch. Facial Plast. Surg., 1999; 1(2), pp. 118-121.

[28] Owsley, T., Taylor, C. The use of gore-tex for nasal augmentation: A retrospective analysis of 106 patient. In: Plastic \&Reconstructive Surgery, Volume 94, Issue 2.

[29] Matthew D. Shoulders and Ronald T. Raines, Collagen Structure and Stability, In: Annu. Rev. Biochem. 2009. 78, pp. 929-58. 
[30] Dinescu, S., Galateanu, B., Albu, M., Lungu, A., Radu, E., Hermenean, A. and Costache, M. Biocompatibility assessment of novel collagen-sericin scaffolds improved with hyaluronic acid and chondroitin sulfate for cartilage regeneration, Hindawi Publishing Corporation. In: BioMed Research International, Volume 2013, Article ID 598056, 11 pages.

[31] Fulco, I., Miot, S., Haug, M.D. The Lancet Engineered autologous cartilage tissue for nasal reconstruction after tumour resection: an observational first-in-human trial. In: Early Online Publication, 11 April 2014, Elsevier Ltd.

[32] Yücebaş, K., Taskin, U., Oktay, M.F., at al. The results of polypropylene mesh usage for nasal septal perforation repair: An experimental study. Available at: http://www.researchposters.com/Posters/AAOHNSF/AAO2014/ SP493.pdf.

[33] Pierce, L.M., Asarias, J.R., Nguyen, P.T., Mings, J.R., Gehrich, A.P. Inflammatory cytokine and matrix metalloproteinase expression induced by collagen-coated and uncoated polypropylene meshes in a rat model. In: Am J Obstet Gynecol., 2011; 205(1):82.e1-9. doi: 10.1016/j.ajog.2011.02.045. Epub 2011 Feb 23.

[34] Dias, F.G.F., Prudente, A., Siniscalchi, R.T., Campos de Vidal, B., Zanettini Riccetto, C.L. Can highly purified collagen coating modulate polypropylene mesh immune-inflammatory and fibroblastic reactions? Immunohistochemical analysis in a rat model. In: IntUrogynecol J., October 2014.doi:10.1007/s00192-014-2529-0.

[35] Lukasiewicz, A., Skopinska-Wisniewska, J., Marszalek, A., Molski, S., Drewa, T. Collagen/Polypropylene composite mesh biocompatibility in abdominal wall reconstruction. In: PlastReconstr Surg., 2013 May;131(5):731e40e.doi:10.1097/PRS.0b013e3182865d2c.

[36] van't Riet, M., Burger, J.W., Bonthuis, F., Jeekel, J., Bonjer, H.J. Prevention of adhesion formation to polypropylene mesh by collagen coating: a randomized controlled study in a rat model of ventral hernia repair. In: SurgEndosc., 2004; 18(4):681-685. Epub 2004 Mar 19.

[37] Faulk, D.M., Londono, R., Wolf, M.T., Ranallo, C.A., Carruthers, C.A., Wilemann, J.D., Dearth, C.L., Badylak, S.F. ECM hydrogel coating mitigates the chronic inflammatory response to polypropylene mesh. In: Biomaterials, 2014;35(30):8585-8595.doi:10.1016/j.biomaterials.2014.06.057. Epub 2014 Jul 16.

[38] Dias, F., Dos Santos, A. MP4-16 Can highly purified collagen coating modulate polypropylene mesh immuneinflammatory and fibroblastic reactions? Immunohistochemical analysis in rat model. In: The Journal of Urology, 2014; 191(4) Suppl:e49.doi:10.1016/j.juro.2014.02.216.

[39] Gao, Y., Krpata, D.M., Criss, C.N., Liu, L., Posielski, N., Rosen, M.J., Novitsky, Y.W. Effects of mesenchymal stem cell and fibroblast coating on immunogenic potential of prosthetic meshes in vitro. In: Surgical Endoscopy, 2014; 28(8), pp. 2357-2367.

[40] Gao, Y., Liu, L., Blatnik, J.A., Krpata, D.M., Anderson, J.M., Criss, C.N., Posielski, N., Novitsky, Y.W. Methodology of fibroblast and mesenchymal stem cell coating of surgical meshes: A pilot analysis. In: J Biomed Mater Res Part B, 2014; 102B:797-805.

[41] Rodriguez, S. Alloplastic materials and homografts in nasal reconstruction. April 2005. Available at: http://www.utmb.edu/otoref/grnds/Nasal-Recon-050420/Nasal-Recon-050420.pdf.

[42] Winkler, A.A., Soler, Z.M., Leong, P.L., Murphy, A., Wang, T.D., Cook, T.A. Complications associated with alloplastic implants in rhinoplasty. In: Arch Facial Plast Surg., 2012;14(6):437-441.doi:10.1001/archfacial.2012.583.

[43] Berghaus, A. Implants for reconstructive surgery of the nose and ears. In: GMS Curr Top Otorhinolaryngol Head Neck Surg., 2007; 6:Doc06.

[44] Rai, A., Datarkar, A., Arora, A., Adwani, D.G. Utility of high density porous polyethylene implants in maxillofacial surgery. In: Journal of Maxillofacial and Oral Surgery, 2014; 13(1), pp. 42-46.

[45] Kim, B.J., Lim, J.W., Park, J.H., Lee, Y.H. Dual plane augmentation geniopasty using Gore-Tex chin implants. In: Arch Craniofac Surg., 2014 Aug; 15(2), pp. 82-88.

[46] Giarenisl., Robinson D. Prevention and management of pelvic organ prolapse. In: F1000 Prime Rep., $2014 ; 6$, p. 77.

\title{
Authors:
}

\author{
MIHAI-ALEXANDRU PĂUN¹, ADRIAN FRUNZĂ², ELENA-LUMINIȚA STĂNCIULESCU², \\ TIBERIU-CIPRIAN MUNTEANU ${ }^{2}$, IOAN CRISTESCU ${ }^{2}$, SABINA GRAMA ${ }^{2}$, \\ ALEXANDRU CHIOTOROIU ${ }^{2}$, ALEXANDRA ENE $^{3}$, CARMEN MIHAI $^{3}$ \\ ${ }^{1}$ Clinical Emergency Hospital "Agrippa Ionescu" \\ ${ }^{2}$ Clinical Emergency Hospital Bucharest \\ ${ }^{3}$ The Research and Development Institute for Textile and Leather
}

${ }^{*}$ All the authors equally contributed to this work

Corresponding author:

ADRIAN FRUNZĂ

e-mail: adi_frunza@yahoo.com 


\section{Dependence of colour difference formulae on regular changes of colour coordinates in CIELAB colour space}

DOI: $10.35530 / I T .070 .03 .1525$

\section{REZUMAT - ABSTRACT}

Dependența formulelor de diferență a culorii asupra modificărilor coordonatelor de culoare în spațiul de culoare CIELAB

În spațiul de culoare CIELAB au fost evaluate patru formule de diferențe de culoare [CIELAB (1976), CMC (2: 1), CIE94 (2: 1: 1) și CIEDE2000 (2: 1: 1)] pentru modificările coordonatelor de culoare. Coordonatele $L^{*}$, a* și $b^{*}$ au fost modificate atât ca etape de creștere, cât și de descreștere în diferite regiuni de luminozitate și nuanță ale spațiului de culoare. Dependența și consistența celor patru formule au fost cercetate în funcție de modificări și constante ale coordonatelor de culoare. Scopul studiului empiric a fost de a determina dacă ar putea exista o posibilitate de a utiliza diferite formule de diferențe de culoare în diferite zone de nuanță ale spațiului de culoare CIELAB; în regiunea în vrac, fiecare formulă ar da cele mai bune rezultate și cele mai fiabile rezultate. Studiul empiric a fost realizat folosind un software special care a fost pregătit pentru acest scop. Rezultatele au arătat că CIELAB și CIE94 au dat rezultate corespunzătoare între ele în intervalele de calcul. Toate formulele au prezentat diferite caracteristici de calcul în intervalele de calcul. Formula CMC a dat cele mai mari diferențe de culoare atunci când a fost calculată lângă punctul gri. S-a concluzionat că formula CIEDE2000 se potrivește cel mai bine cu modificările din etapele de calcul. Un software mai complex ar fi necesar pentru a determina sensibilitatea formulelor prin care se poate efectua calculul prin modificarea tuturor coordonatelor $\left(L^{*}\right.$, a* și $\left.b^{*}\right)$ în același timp.

Cuvinte-cheie: CIE, formula de diferență de culoare; CIELAB; CMC; CIEDE2000; CIE94

Dependence of colour difference formulae on regular changes of colour coordinates in CIELAB colour space

Four colour difference formulae [CIELAB (1976), CMC (2:1), CIE94 (2:1:1) and CIEDE2000 (2:1:1)] were assessed in CIELAB colour space for regular changes in colour coordinates. $L^{*}, a^{*}$ and $b^{*}$ coordinates were changed regularly both as increasing and decreasing steps in different lightness and hue regions of the colour space. The dependence and consistency of the four formulae were researched depending on regular and constant colour coordinate changes. The aim of the empirical study was to determine if there could be a possibility of using different colour difference formulae in different hue regions of CIELAB colour space; in the region of bulk that each formula would give the best fitting and the most reliable results. The empirical study was carried out by using a special software which was prepared for the purpose. The results showed that CIELAB and CIE94 gave corresponding results with each other in the computing ranges. All the formulae showed different computing characteristics in the computation ranges. CMC formula gave the highest colour differences when computing near the grey point. It was concluded that CIEDE2000 formula suited itself the best according to the changes in computing steps. A more complicated software would be necessary to determine the sensitivity of the formulae by which the computing would be performed by changing all the coordinates $\left(L^{*}, a^{*}\right.$ and $\left.b^{*}\right)$ at the same time.

Keywords: CIE, colour difference formula; CIELAB; CMC; CIEDE2000; CIE94

\section{INTRODUCTION}

CIE, International Commission on Illumination, defined the CIELAB colour space in 1976 which was indented to be a visually uniform one. The space was characterized by three axes that represented the three colour coordinates which were lightness $\left(L^{*}\right)$, red-green $\left(a^{*}\right)$ and yellow-blue $\left(b^{*}\right)$ together with two supplementary colour related terms of chroma $\left(C^{*}\right)$ and hue angle $\left(h^{\circ}\right)$. After the calculation of the three tristimulus values ( $\mathrm{X}, \mathrm{Y}$, and $\mathrm{Z}$ ) under specified illumination and viewing conditions, they are used as the computing components in the calculation of colour coordinates to designate the place of the colour in CIELAB colour space. Together with the definition of CIELAB colour space, CIELAB (1976) colour difference formula was developed to calculate the colour difference between two colours in the space.
However, CIELAB colour space is not truly visually uniform which means that equal colour difference magnitude appear of different visual magnitudes in different regions of the colour space.

When the difference between two colours are calculated by CIELAB colour difference formula, the formula calculates the linear (Euclidean) distance between the two points in the CIELAB colour space by using the three colour coordinates of $L^{*}, a^{*}$ and $b^{*}$. Because of the non-uniformity of the CIELAB colour space and the setup of CIELAB (1976) formula, the colour difference obtained is free from human eye sensitivity. Human eye is sensitive to different kinds of changes in the shade(s) under observation. Human visual system perceives the differences in different magnitudes even though they may have the same colour difference calculated by CIELAB (1976) 
formula. For this reason, the same vector distance may not be perceptually the same for all colours.

A perceptually uniform colour space is the one in which Euclidean distances highly agree with perceptual colour differences. Originating from the problem of inconsistency of calculated and visual colour differences, advanced colour difference formulae were developed which were based on the modification of CIELAB [1]. New colour spaces like CIELAB and colour appearance spaces like CIECAM02 were researched in recent years [2-3]. But perceptual uniformity of these spaces were found insufficient for various applications so that new colour difference formulae were developed and standardized, such as CMC [4], CIE94 [5] and CIEDE2000 [6, 7]. Visual experiments showed that the CIECAM02 space was also not perceptually uniform and new colour difference formulae could be applied to enhance the correlation to the visual data. The scientific approach related with this subject was well established by Urban et al. Papers were published to discuss the new formula CIEDE2000 [8-13].

Human visual system is sensitive to naturals and high-chroma colours depending on their lightness and chroma values. But the sensitivity is ruled in different characteristics in different parts of the CIELAB colour space and on $a^{*}-b^{*}$ colour plane. For this reason, determination of the exact combination and point of hue angle and its related chroma of a colour on $a^{*}-b^{*}$ colour plane is important in the calculation of colour difference. The advanced colour difference formulae differ from each other in the way of more precise calculation of chroma and hue differences in CIELAB colour space.

Colour is very important for human life because human beings have their own individual colour choices in every phase of daily life. In textiles, uniform colour is important especially in plain garments because these garments are made of many different parts which were cut in preparation and later associated to each other by means of sewing. But each part cannot be chosen from the same area but collected from different parts of the whole fabric depending on the applications which are carried out by ready cloth making industry. For this reason there is a need for a precise colour difference formula for colour matching. Questions arise which formula should be used according to different magnitudes in industrial applications or it would be possible to use a hybrid system to deal with different colour difference changes [14].

Evaluation of colour difference formulae for different colour-difference magnitudes were carried out by researchers. Wang et al. found that colour-difference formulae performed significantly different when applied to estimate large and small colour differences. They extended the CIE recommended colour space model, CIECAM02, to form three new uniform colour spaces, CAM02-SDC, CAM02-LCD and CAM02-UCS, for estimating small-, large-, and overall ranges of colour differences respectively [14]. Xu et al. tested CIELAB-based colour-difference formulae using large colour differences [10].
Melgosa published testing results of CIELAB-based colour difference formulae [15]. Kandi and Tehran investigated the effect of fabric texture on the performance of colour difference formula [16]. Becerir discussed the differences between CIEL* $a * b *$ and Hunter L, a, b colour coordinates by wash fastness tests [17]. Sennaroglu et al. used CMC formula in accordance with artificial neural network.

This paper researched the responses of four colour difference formulae in different lightness and hue regions of CIELAB colour space and tried to investigate the consistency of the formulae from small to very large colour differences.

\section{MATERIALS AND METHODS}

Dependence of colour difference formulae on regular changes of colour coordinates in CIELAB colour space was researched by a specially prepared software. The software was prepared by using C\# programming. Colour difference formulae were prepared as Excel worksheet and they were used as the computation references in the software. The software prepared the results again in Excel worksheet between the preferred limits of coordinates. In order to make a better graphical presentation, four or five results were omitted in the related figures otherwise a black line was obtained for each formula which enabled to make differentiation between lines and curves. The

Table 1

START AND END POINTS OF LIGHTNESS COORDINATE FOR INCREASING AND DECREASING COMPUTING

\begin{tabular}{|l|c|c|c|c|c|c|}
\hline \multirow{2}{*}{ Figure } & \multicolumn{3}{|c|}{ Start point } & \multicolumn{3}{c|}{ End point } \\
\cline { 2 - 8 } & $\mathbf{L}^{*}$ & $\mathbf{a}^{*}$ & $\mathbf{b}^{*}$ & $\mathbf{L}^{*}$ & $\mathbf{a}^{*}$ & $\mathbf{b}^{*}$ \\
\hline Figure 1, $a$ & 20 & 1 & 1 & 95 & 1 & 1 \\
\hline Figure 1, $b$ & 95 & 1 & 1 & 20 & 1 & 1 \\
\hline Figure 2, $a$ & 50 & 1 & 1 & 100 & 1 & 1 \\
\hline Figure 2, $b$ & 50 & 1 & 1 & 0 & 1 & 1 \\
\hline
\end{tabular}

Table 2

START AND END POINTS OF RED-GREEN AND

YELLOW-BLUE COORDINATES FOR INCREASING AND DECREASING COMPUTING

\begin{tabular}{|l|c|c|c|c|}
\hline \multirow{2}{*}{ Figure } & \multicolumn{2}{|c|}{ Start point } & \multicolumn{2}{c|}{ End point } \\
\cline { 2 - 5 } & $\mathbf{a}^{*}$ & $\mathbf{b}^{*}$ & $\mathbf{a}^{*}$ & $\mathbf{b}^{*}$ \\
\hline Figure 3, $a$ & -30 & 0 & 0 & 30 \\
\hline Figure 3, $b$ & 0 & 30 & -30 & 0 \\
\hline Figure 4, $a$ & 0 & -30 & 30 & 0 \\
\hline Figure 4, $b$ & 30 & 0 & 0 & -30 \\
\hline Figure 5, $a$ & -30 & -30 & 30 & 30 \\
\hline Figure 5, $b$ & 30 & 30 & -30 & -30 \\
\hline Figure 6, $a$ & -30 & -30 & $-0,01$ & $-0,01$ \\
\hline Figure 6, $b$ & $-0,01$ & $-0,01$ & -30 & -30 \\
\hline Figure 7, $a$ & 0,01 & 0,01 & 30 & 30 \\
\hline Figure 7,b & 30 & 30 & 0,01 & 0,01 \\
\hline
\end{tabular}


start points presented in tables 1 and 2 were taken as the "Reference" colour in computing. "Sample" colours were the ones which were obtained by regular step increases or decreases in the corresponding coordinates.

\section{RESULTS AND DISCUSSION}

Dependence of four colour difference formulae on regular changes in lightness $\left(L^{*}\right)$ coordinate was assessed in figures 1 and 2 for different start and end points. Lightness coordinates were changed between 0 and 100 at the point of $a^{*}=b^{*}=1$. Coordinates were increased and decreased by 0.25 units at regular steps in the corresponding figures. Start and end points of the lightness coordinate were presented in table 1 for the corresponding figures.

Colour difference results were calculated between $L^{*}=20$ and $L^{*}=95$ by 0.25 units of increases and decreases in figures $1, a$ and $1, b$ respectively. $L^{*}=20$ coordinate was chosen as the minimum lightness coordinate because of the computing rule of $\mathrm{CMC}$ formula at $L^{*}=16$. Colour difference results were computed between $L^{*}=50$ and $L^{*}=100$ by 0.25 units of increase in figure 2, a and they were computed between $L^{*}=50$ and $L^{*}=0$ by 0.25 units of decrease in figure $2, b$.

An overall discussion of the computed colour differences which were presented in figures 1 and 2 showed that colour difference results obtained by computing according to CIELAB, CMC and CIE94 formulae resulted in linear matching (a line) while computing according to CIEDE2000 formula resulted in a curve matching (ascending or descending).
Computing according to CIE94 formula gave almost the half results of computing according to CIELAB formula in figures 1 and 2 . Computing according to these two formulae were insensitive to regular increases or decreases at the lightness coordinate. They always retained their corresponding own values although the computing ranges changed in opposite directions in figures $1, a-1, b$ and figures $2, a-2, b$. In figures $1, a$ and $1, b$, the colour difference computing was performed in opposite directions (increasing or decreasing steps) between $L^{*}=20$ and $L^{*}=95$. Both CMC and CIEDE2000 formulae gave two distinctly different results of their own although only the start and end points had changed on lightness axis. CMC results were very high in figure 1 , a but they were the lowest in figure $1, b$. Computing according to CIEDE2000 formula gave two different polynomial curves.

In figures 2, $a$ and 2, b, CIEDE2000 formula gave the same results in the computing ranges. CMC formula would also give the same results in the computing ranges in figures 2, $a$ and $2, b$ as understood from its' lines in the figures but because of its' formula specialty at $L^{*}=16$, a step increase was obtained in figure $2, b$ at the computing point of $L^{*}=16$.

CIELAB and CIE94 results were consistent with lightness changes in the different computing ranges presented in figures $1, a-1, b$ and figures $2, a-2, b$. CMC and CIEDE2000 results were even when computing was performed from $L^{*}=50$ to $L^{*}=100$ (figure 2 , a) and from $L^{*}=50$ to $L^{*}=0$ (fig. $2, b$ ). But the characteristic of their results changed considerably when computing was performed between $L^{*}=20$ and $L^{*}=95$ (figures $1, a-1, b)$ both in increasing and decreasing steps.

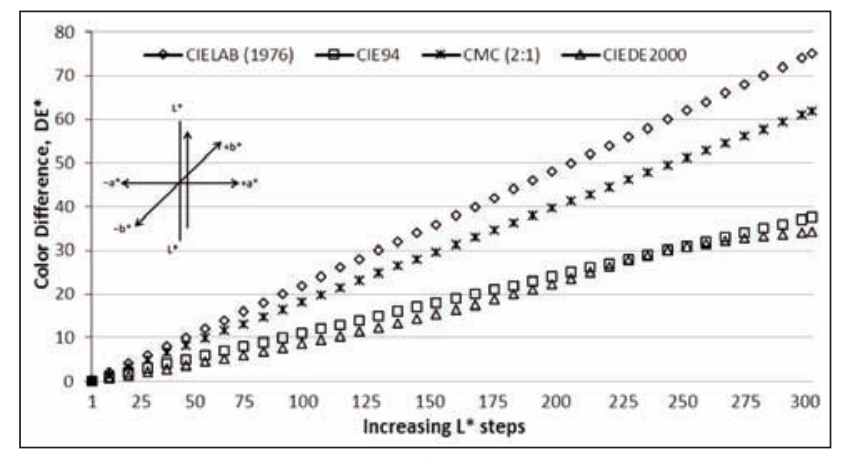

a

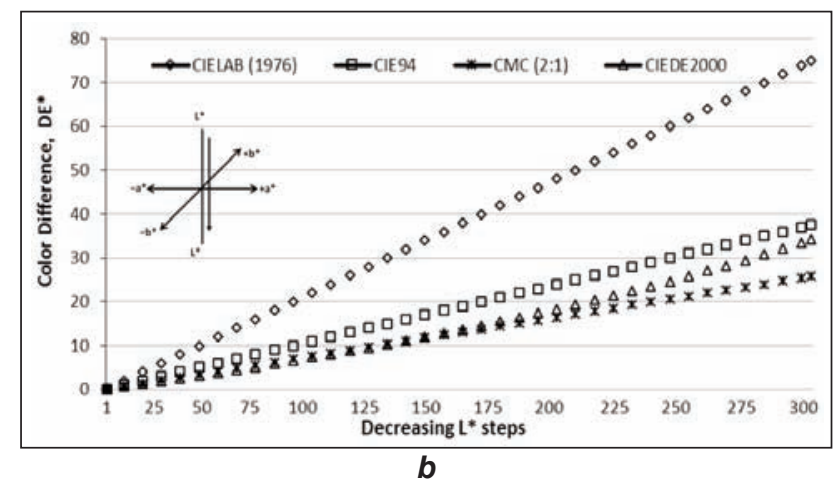

Fig. 1. Colour difference results (from $L^{*}=20$ to $L^{*}=95$; $\left.a^{*}=b^{*}=1\right)(a)$; Colour difference results (from $L^{*}=95$ to $\left.L^{*}=20 ; a^{*}=b^{*}=1\right)(b)$

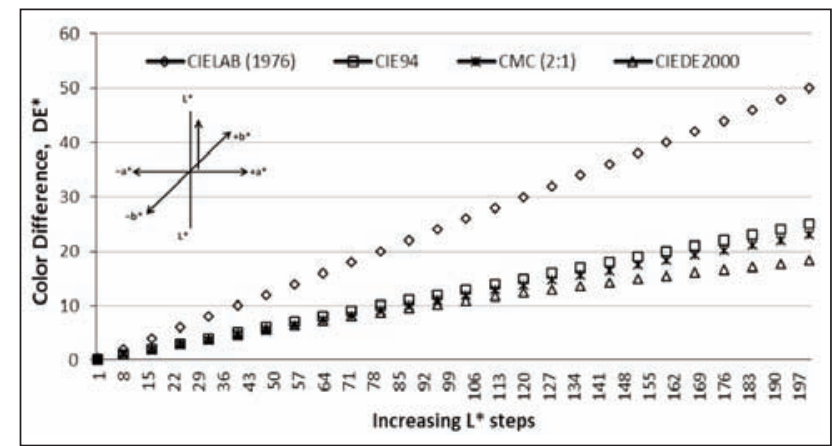

a

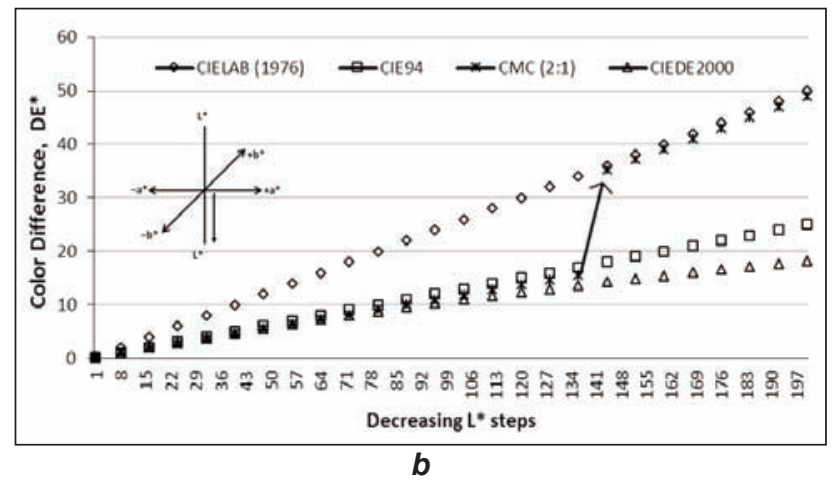

Fig. 2. Colour difference results (from $L^{*}=50$ to $L^{*}=100$; $\left.a^{*}=b^{*}=1\right)(a)$; Colour difference results (from $L^{*}=100$ to $\left.L^{*}=50 ; a^{*}=b^{*}=1\right)(b)$ 
Dependence of the four colour difference formulae on regular changes of red-green $\left(a^{*}\right)$ and yellow-blue $\left(b^{*}\right)$ coordinates were assessed in figures $3-7$ for different hue regions and start and end points. Lightness $\left(L^{*}\right)$ coordinate was taken as $L^{*}=50$ constant in all computations so that all the calculations were conducted on $a^{*}-b^{*}$ colour plane at $L^{*}=50$. $a^{*}$ and $b^{*}$ coordinates were increased or decreased by 0.30 units between start and end points in the four sub-regions (hue regions) of $a^{*}-b^{*}$ colour plane. The computing results were presented in the corresponding figures.

The computing was conducted in the second hue region $\left(90^{\circ}-180^{\circ}\right)$ of $a^{*}-b^{*}$ colour plane at increasing and decreasing steps in figures $3, a$ and $3, b$ respectively. Linear results were obtained by CIELAB formula while polynomial results were obtained by the other three formulae. CIELAB and CIE94 formulae gave the same results of their own in figures 3 , $a$ and $3, b$. CMC and CIEDE2000 gave two different polynomial curves of their own although only the computing direction had changed. The highest colour difference results were obtained by CIELAB when computing was performed in increasing steps in figure 3 , a while the highest colour difference results were obtained by CMC when computing was performed in decreasing steps in figure $3, b$.

The computing was conducted in the fourth hue region $\left(270^{\circ}-360^{\circ}\right)$ of $a^{*}-b^{*}$ colour plane at increasing and decreasing steps in figures $4, a$ and $4, b$ respectively. Similar to the results presented in figures $3, a$ and $3, b$, linear results were obtained by CIELAB and polynomial results were obtained by the other three formulae. Also the same colour difference
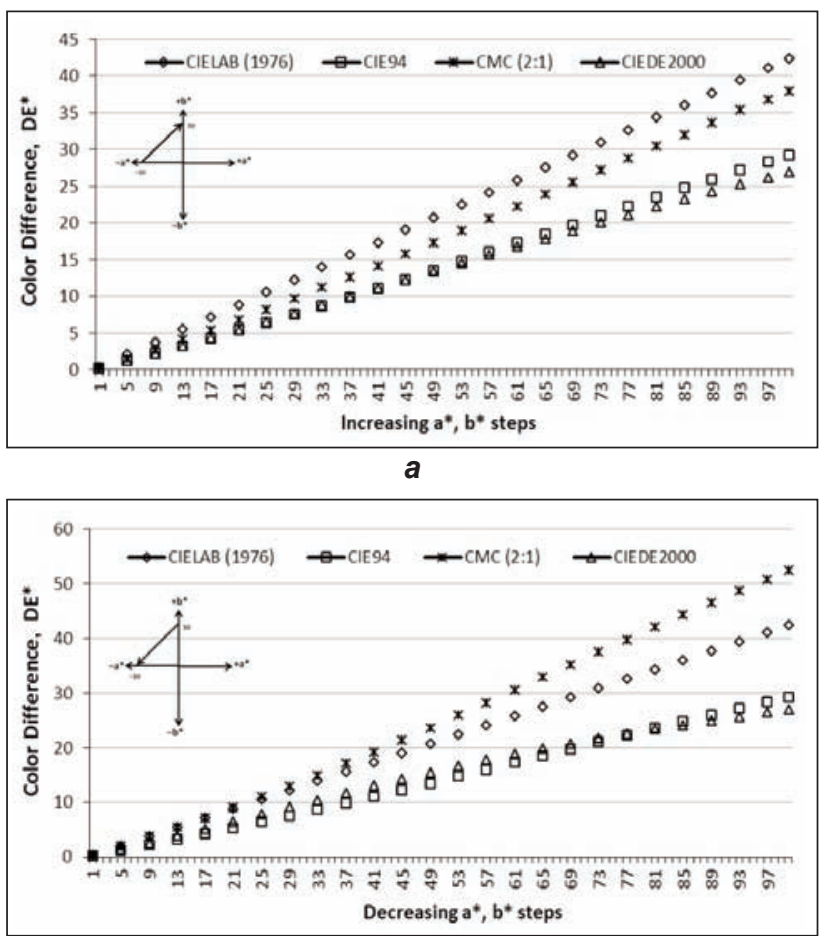

b

Fig. 3. Colour difference results (from $a^{*}=-30, b^{*}=0$ to $\left.a^{*}=0, b^{*}=30 ; L^{*}=50\right)(a)$; Colour difference results (from $a^{*}=0, b^{*}=30$ to $a^{*}=-30, b^{*}=0 ; L^{*}=50$ ) (b) results were obtained by CIELAB in figures 3-4. CIE94 gave the same results in figures $4, a$ and $4, b$ but different from its behaviour in figures $3, a$ and $3, b$, the computed results were not almost the half of CIELAB results. CMC and CIEDE2000 gave two different polynomial curves of their own although only the computing direction had changed, similar to the results presented in figures $3, a$ and $3, b$. The highest colour difference results were obtained by CIELAB when computing was performed both in increasing and decreasing steps in figures $4, a$ and $4, b$. The lowest colour difference results were obtained by CMC when computing was performed in increasing steps in figure $4, a$. CMC colour difference results presented a different character when the computing was performed in decreasing steps in figure $4, b$ and they were very close to the results of CIELAB.

The computing was conducted starting from the third hue region $\left(180^{\circ}-270^{\circ}\right)\left(a^{*}=b^{*}=-30\right)$ to ending in the first hue region $\left(0^{\circ}-90^{\circ}\right)\left(a^{*}=b^{*}=30\right)$ and starting from the first hue region $\left(a^{*}=b^{*}=30\right)$ to ending in the third hue region $\left(a^{*}=b^{*}=-30\right)$ of $a^{*}-b^{*}$ colour plane in figures $5, a$ and $5, b$ respectively. Similar to the results presented in figures $3-4$, linear results were obtained by CIELAB and polynomial results were obtained by the other three formulae. CIELAB, CIE94 and CIEDE2000 gave individually the same results of their own in figures $5, a$ and 5, $b$. CMC, CIE94 and CIEDE2000 gave thresholds at the grey point of $\left(a^{*}=b^{*}=0 ; L^{*}=50\right)$ $a^{*}-b^{*}$ colour plane. The three formulae changed their computing character while passing the grey point. The highest colour difference values were obtained by CIELAB when computing both in increasing and decreasing steps in figures $5, a$ and $5, b$. CMC results

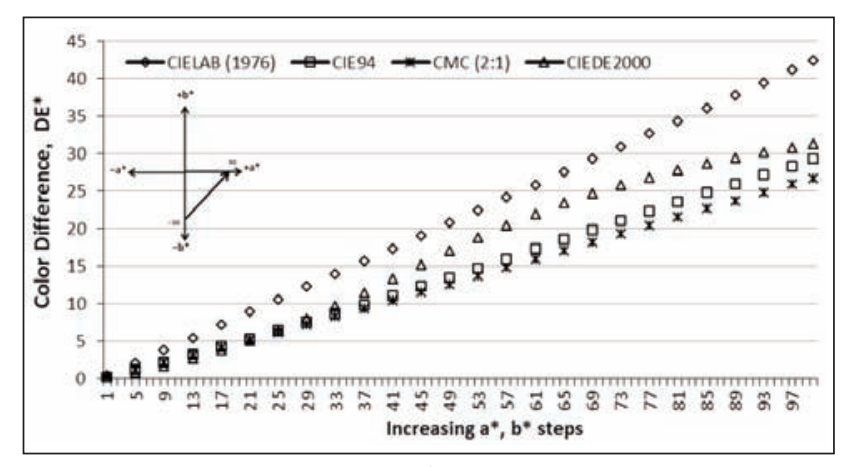

a

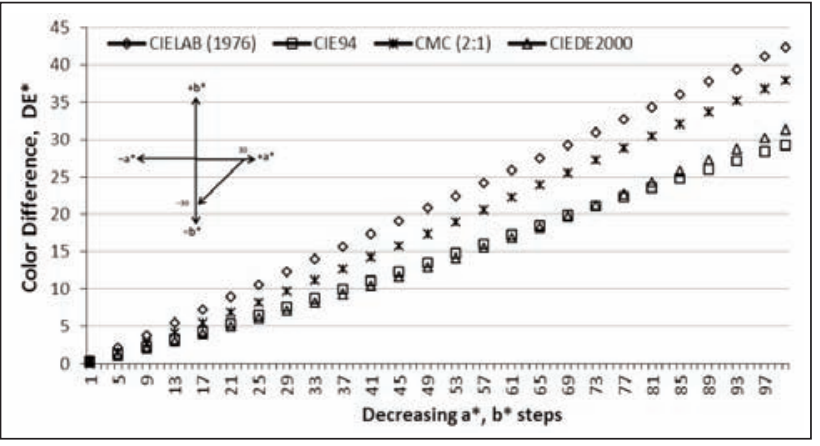

b

Fig. 4. Colour difference results (from $a^{*}=0, b^{*}=-30$ to $\left.a^{*}=30, b^{*}=0 ; L^{*}=50\right)(a)$; Colour difference results (from $a^{*}=30, b^{*}=0$ to $a^{*}=0, b^{*}=-30 ; L^{*}=50$ ) (b) 


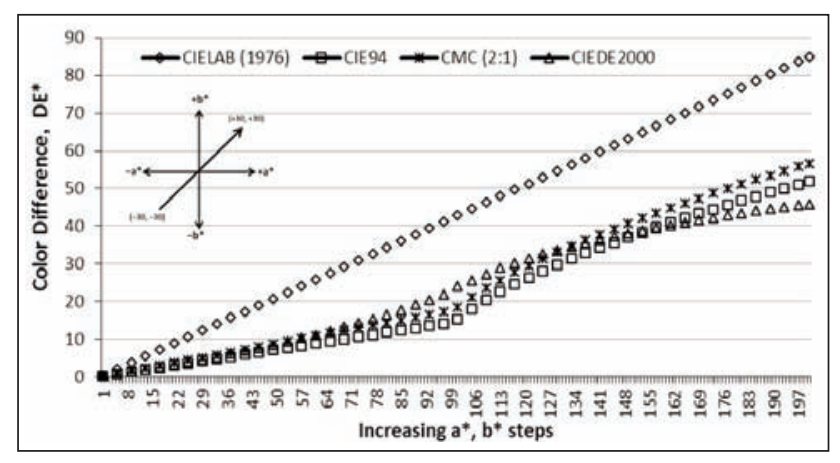

a

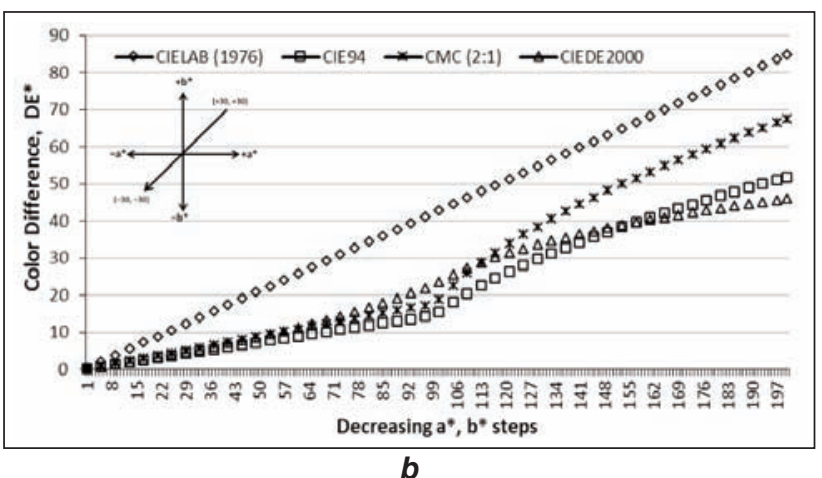

Fig. 5. Colour difference results (from $a^{*}=-30, b^{*}=-30$ to $\left.a^{*}=30, b^{*}=30 ; L^{*}=50\right)(a)$; Colour difference results (from $a^{*}=30, b^{*}=30$ to $a^{*}=-30, b^{*}=-30 ; L^{*}=50$ ) (b)

differed considerably when computing direction had changed, similar to figures $3-4$.

The computing was conducted in the third hue region $\left(180^{\circ}-270^{\circ}\right)$ of $a^{*}-b^{*}$ colour plane at increasing and decreasing steps in figures $6, a$ and $6, b$ respectively. Polynomial results were obtained by CIEDE2000 and linear results were obtained by the other three formulae. CIELAB gave the same results in figures $6, a$ and $6, b$. Also almost the same results were obtained when computing was performed according to CIELAB and CIE94 in figure 6,b. Computing according to CMC and CIEDE2000 showed distinct differences when computing direction had changed in figures $6, a$ and $6, b$. CIEDE2000 gave ascending and descending curves in figures $6, a$ and $6, b$ respectively. CMC results were the lowest ones with CIE94 results in figure 6 , a but $\mathrm{CMC}$ results were far the highest one in figure $6, b$. Computing according to CMC, CIE94 and CIEDE2000 gave distinct differences in the third hue region of $a^{*}-b^{*}$ colour plane when computing directions were changed.

The computing was conducted in the first hue region $\left(0^{\circ}-90^{\circ}\right)$ of $a^{*}-b^{*}$ colour plane at increasing and decreasing steps in figures $7, a$ and $7, b$ respectively. Similar to the results presented in figures $6, a$ and $6, b$, polynomial results were obtained by CIEDE2000 and linear results were obtained by the other three formulae. CIELAB gave the same results in figures 6-7 irrespective of the hue region and computing direction. Also similar to figure $6, b$, CIELAB and CIE94 gave almost the same results in figure $7, a$, and computing according to CMC and CIEDE2000 showed distinct differences when computing direction had changed in figures $7, a$ and $7, b$. CIEDE2000

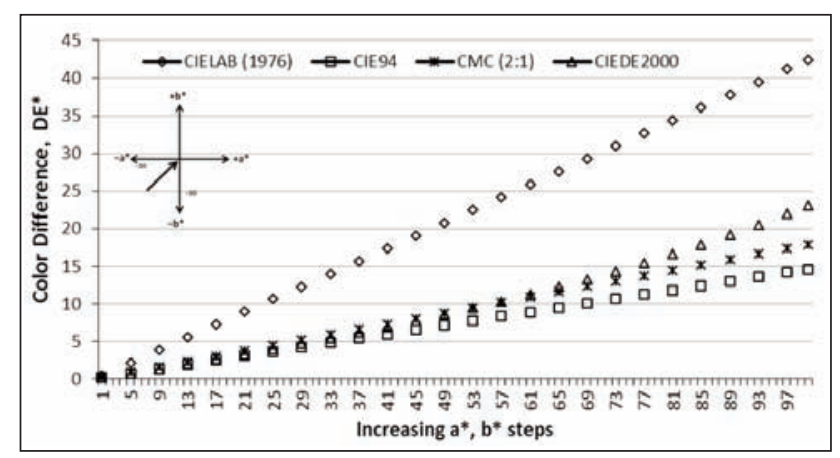

a

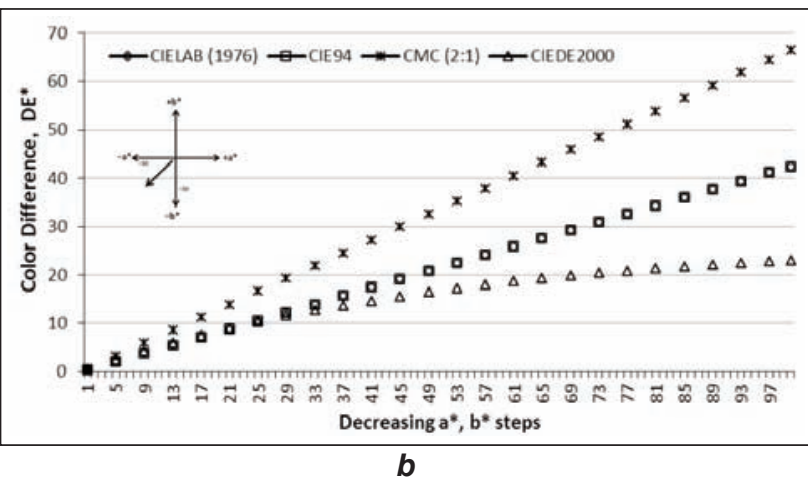

Fig. 6. Colour difference results (from $a^{*}=-30, b^{*}=-30$ to $\left.a^{*}=-0.01, b^{*}=-0.01 ; L^{*}=50\right)(a)$; Colour difference results (from $a^{*}=-0.01, b^{*}=-0.01$ to $\left.a^{*}=-30, b^{*}=-30 ; L^{*}=50\right)(b)$

gave descending and ascending curves in figures $7, a$ and $7, b$ respectively. The highest colour differences were obtained when computing was performed according to $\mathrm{CMC}$ in figure $7, a$.

When figures 6-7 were considered closer, it was observed that figures $6, a$ and $7, b$, and figures $6, b$ and $7, a$ were the same; i.e., the same colour difference results were obtained. This meant that computing in the third hue region with increasing steps (figure 6,a) and computing in the first region with decreasing steps (figure $7, b$ ) resulted in the same colour difference values, i.e., when the computing was performed approaching to the grey point $\left(a^{*}=b^{*}=0 ; L^{*}=50\right)$. Similarly, computing in the third hue region with decreasing steps (figure $6, b$ ) and computing in the first region with increasing steps (figure $7, a$ ) resulted in the same colour difference values, i.e., when computing was performed receding from the grey point $\left(a^{*}=b^{*}=0 ; L^{*}=50\right)$.

An overall consideration of figures $1-2$, where $L^{*}$ coordinates were increased and decreased at constant steps at the point of $a^{*}=b^{*}=1$, showed that CIELAB gave linear and the same results in the corresponding figures $1, a-1, b$ and $2, a-2, b$. Also CIE94 gave almost the half results of CIELAB in figures 1-2. CMC and CIEDE2000 gave characteristic results when computing was performed at increasing and decreasing steps between $L^{*}=20$ and $L^{*}=95$ in figures $1, a$ and $1, b$. These two formulae gave the same results of their own when computing was performed above and under $L^{*}=50$ (figures $2, a$ and $2, b$ ). The only exception was CMC formula in figure $2, b$ because of its specialty at $L^{*}=16$. 


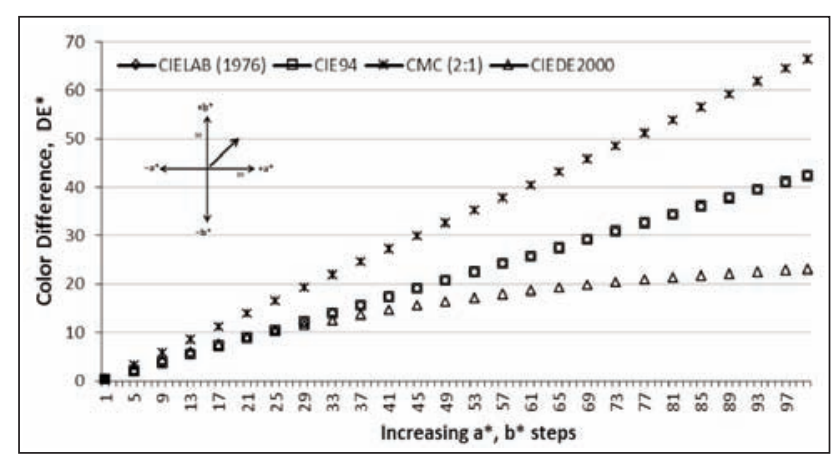

a

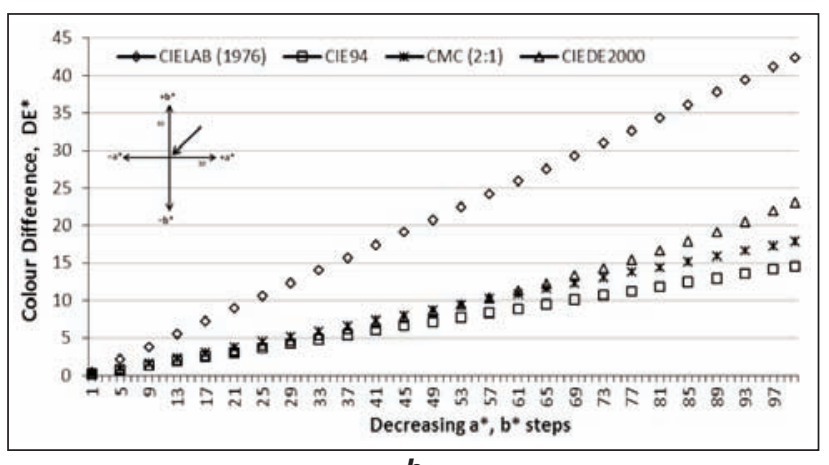

b

Fig. 7. Colour difference results (from $a^{*}=0.01, b^{*}=0.01$ to $\left.a^{*}=30, b^{*}=30 ; L^{*}=50\right)(a)$; Colour difference results (from $a^{*}=30, b^{*}=30$ to $\left.a^{*}=0.01, b^{*}=0.01 ; L^{*}=50\right)(b)$

An overall consideration of figures $3-4$, where $a^{*}$ and $\mathrm{b}^{*}$ coordinates were increased and decreased at constant steps on the second and on the fourth hue regions of $a^{*}-b^{*}$ colour plane, showed that the same linear equation was obtained for CIELAB in all computing indicating that CIELAB formula was consistent to computing in any hue area of the CIELAB colour space either the computing was performed at constant increasing or decreasing steps. This fact had been already known in colour science because of the regular computing (calculation) characteristic of the CIELAB formula. Similar to CIELAB results, CIE94 formula gave the same results of its own in the corresponding figures $3-4$. CIE94 formula gave results which indicated that it was insensitive to computing in regular increasing and decreasing steps in the second and the fourth hue regions of $a^{*}-b^{*}$ colour plane. On the other hand, CMC formula was sensitive to the second and the fourth hue regions and to regular increasing and decreasing steps in the corresponding figures of 3-4. However, CMC formula gave almost the same results when computing was performed in the second hue region of $a^{*}-b^{*}$ colour plane according to increasing steps (figure $3, a$ ) and in the fourth region of $a^{*}-b^{*}$ colour plane according to decreasing steps (figure $4, a)$. A corresponding behaviour was not observed in the same regions when computing direction changed, in figures $3, b$ and $4, a$. CIEDE2000 formula was sensitive to regularly increasing and decreasing steps in the second and fourth hue regions of $a^{*}-b^{*}$ colour plane. Regular descending curves were obtained in the second hue region of $a^{*}-b^{*}$ colour plane (figures $3, a$ and $3, b$ ). However, a completely different character was obtained in figures $4, a$ and
$4, b$ where the computing was performed in the fourth hue region. The polynomial curves obtained in this region for regularly increasing and decreasing steps differed from each other considerably.

An overall consideration of figures $5, a-5, b$ where $a^{*}$ and $b^{*}$ coordinates were increased and decreased at constant steps through the first and third regions of $a^{*}-b^{*}$ colour plane at $L^{*}=50$, showed that only CMC formula gave different results in the corresponding figures while the other three formulae gave the same results of their own. CIELAB gave linear results similar to the ones presented in figures 1-4. CMC, CIE94 and CIEDE2000 gave thresholds when computing passed through the grey point of $a^{*}-b^{*}$ colour plane. CIEDE2000 results changed from ascending character to descending character while CMC and CIE94 results considerably increased in a descending character in both figures of $5, a$ and $5, b$.

An overall consideration of figures $6-7$ where $a^{*}$ and $b^{*}$ coordinates were increased and decreased at constant steps the third (figures $6, a$ and $6, b$ ) and in the first (figures $7, a$ and $7, b$ ) regions of $a^{*}-b^{*}$ colour plane at $L^{*}=50$, showed that all the four formulae were sensitive to computing according to regular changes in the third and first hue regions of $a^{*}-b^{*}$ colour plane. Computing according to increasing steps in the third hue region (figure $6, a$ ) corresponded with computing to decreasing steps in the first hue region (figure $7, b$ ) and computing according to increasing steps in the first hue region (figure $7, a$ ) corresponded with computing according to decreasing steps in the third hue region (figure $6, b$ ). The four formulae gave corresponding results of their own when computing came closer to the grey point (fig- ures $6, a$ and $7, b$ ) and when the computing receded from the grey point (figures $6, b$ and $7, a$ ). CMC formula gave the highest colour difference results when the computing receded from the grey point and also CIELAB and CIE94 gave almost the same results.

The computing characteristics of the four formulae changed considerably in the four hue regions not only depending on the colours (hues) in the region but also on the way of calculation of colour differences either in increasing or decreasing steps. Studies are being carried out by researchers on real colours and real observers to make a final conclusion about the choice of the most reliable formula but this research revealed that the continuity of the computing characteristics of the âformulae in CIELAB colour space were also important. Depending on the computing results presented in this paper, it was concluded that CIEDE2000 formula suited itself the best according to the changes in computing steps.

\section{CONCLUSION}

The purpose of this paper was to research the computing characteristics of the four colour difference formulae according to regular coordinate changes in the CIELAB colour space. The computing applications were made on lightness axis and on four hue regions of $a^{*}-b^{*}$ colour plane. Questions arise on the possibility of usage of the colour difference formulae in CIELAB colour space because of the ununiformity 
of the space. This research tried to find a possible answer if it would be suitable or convenient to use different colour difference formulae in different hue regions of CIELAB colour space. The computing revealed that $C I E L A B$ formula was insensitive to regular lightness and hue changes in the colour space and always linear character of colour difference was obtained. CIEDE2000 always gave polynomial results wherever the computing was carried out. The most differing colour difference results were obtained by CMC and CIELAB2000. Especially CMC formula showed distinct differences when computing changed from regular increases to regular decreases or vice versa in different hue regions. It could be stated that the more the results of a colour difference formula dif- fer according to computing regions of $a^{*}-b^{*}$ colour plane the more sensitive the formula to the changes in hue differences. If this statement could be considered as true, then CMC and CIEDE2000 formulae would be judged as the most sensitive colour difference formulae to regular changes in hue. However, CMC gave very distinct values especially when the computing directions changed. CIEDE2000 formula resulted in more even results than the others and implied that it could suit itself to the computing areas and directions better than the others.

\section{ACKNOWLEDGEMENT}

The authors thank M. Medeni Baykal for his kind support in the preparation of the computing software.

\section{BIBLIOGRAPHY}

[1] Urban, P., Berns, S.R., Rosen, M.R. Constructing Euclidean color spaces on color difference formulas, In: $15^{\text {th }}$ Color Imaging Conference Final Program and Proceedings, Society for Imaging Science and Technology, 2007, pp. 77-82.

[2] CIE, A colour appearance model for colour management systems: CIECAM02, CIE Publication No. 159-2004.CIE Central Bureau, Vienna, Austria, 2004

[3] Luo M.R., Cui G., Li C. Uniform colour spaces based on CIECAM02 colour appearance model, In: Color Research and Application, 2006, vol. 31, no. 4, pp. 320-330.

[4] BS 6923, Method for calculation of small color differences. Committee of the Society of Dyers and Coloristsand British Standard Institution, London, UK, 1988.

[5] CIE, Industrial colour-difference evaluation, CIE Publication No. 116-1995, CIE Central Bureau, Vienna, Austria, 1995.

[6] CIE, Improvement to industrial colour-difference evaluation. CIE Publication No. 142-2001, CIE Central Bureau, Vienna, Austria, 2001

[7] Luo, M.R., Cui, G., Rigg B. The development of the CIE 2000 colour-difference formula: CIEDE2000, In: Color Research and Application, 2001, vol. 26, no. 5, pp. 340-350.

[8] Luo, M.R., Cui, G., Rigg, B. Further comments on CIEDE2000, In: Color Research and Application, 2002, vol. 27, no. 2, pp. 127-128.

[9] Kuehni, R.G., CIEDE2000: milestone of final answer?, In: Color Research and Application, 2002, vol. 27, no. 2, pp. 126-127.

[10] Xu, H., Yaguchi, H., Shiori, S. Testing CIELAB-based color-difference formulae using large color differences, In: Optical Review, 2001, vol. 8, no. 6, pp. 487-494.

[11] Sharma, G., Wu, W., Dalal, E.N. The CIEDE2000 color-difference formula: Implementation notes, Supplementary test data, and mathematical observations, In: Color Research and Application, 2005, vol. 30, no. 1, pp. 21-30.

[12] Yang, Y., Ming, J., Yu, N. Color image quality assessment based on CIEDE2000, In: Advances in Multimedia; 2012, Article ID 273723, 6 pages, doi:10.1155/2012/273723.

[13] Luo, M.R., Rigg, B. Chromaticity-discrimination ellipses for surface colours, In: Color Research and Application, 1986, vol. 11, no. 1, pp. 25-42.

[14] Wang, H., Cui, G., Luo, R., Xu, H. Evaluation of colour-difference formulae for different colour-difference magnitudes, In: Color Research and Application, 2012, vol. 37, no. 5, pp. 316-325.

[15] Melgosa, M. Testing CIELAB-based color difference formulas, In: Color Research and Application, 2000, vol. 25, no. 1 , pp. $49-55$.

[16] Kandi, S.G., Tehran, M.A. Investigating the effect of texture on the performance of color difference formulae, In: Color Research and Application, 2010, vol. 35, no. 2, pp. 94-100.

[17] Becerir, B. Assessment of colour properties of reactive dyed cotton fabrics under different illuminants by using CIELAB and hunter systems, In: Tekstilve Konfeksiyon, 2010, vol. 20, no. 2, pp. 145-154.

[18] Sennaroglu, B., Oner, E., Senvar, O. Colour recipe prediction in dyeing acrylic fabrics with fluorescent dyes using artificial neural network, In: Indutria Textila, 2014, vol. 65, no. 1, pp. 22-28.

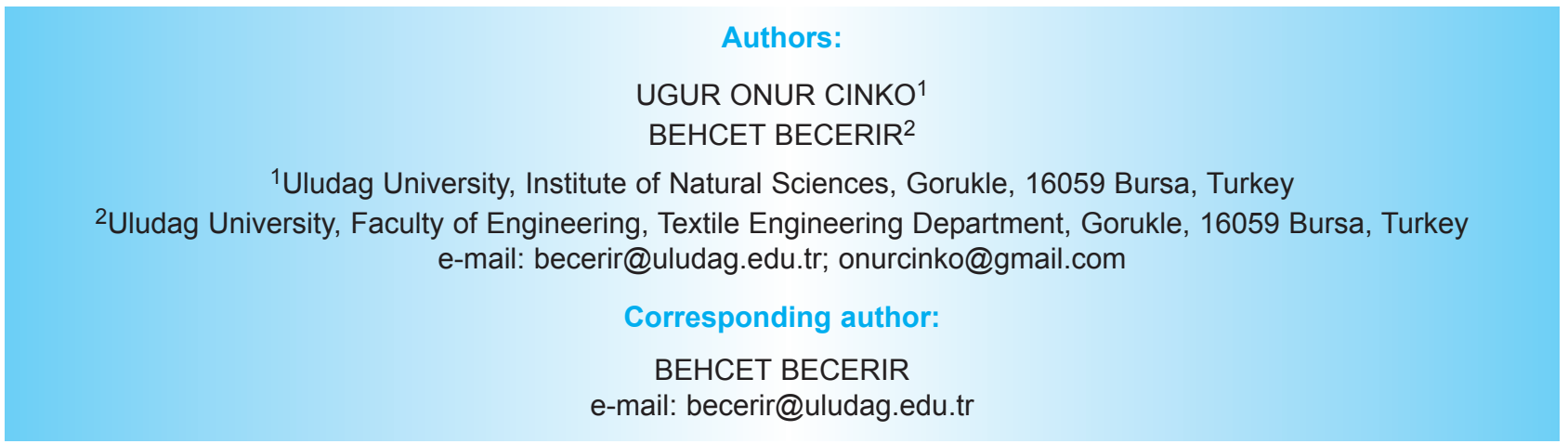




\title{
Inclusion complexes of $\beta$-cyclodextrine with $\mathrm{Fe}_{3} \mathrm{O}_{4} @ \mathrm{HA} @ \mathrm{Ag}$ Part I: Preparation and characterization
}

\author{
DOI: $10.35530 / I T .070 .03 .1548$
}

\section{REZUMAT - ABSTRACT \\ Complecși de incluziune ai $\beta$-ciclodextrinei cu Fe $\mathrm{O}_{4} @ \mathrm{HA} @ A g$ Partea I: Preparare și caracterizare}

În acest studiu, a fost abordată prepararea complecșilor de incluziune în conformitate cu tehnicile de malaxare și amestecare fizică la 1:1 și 1:2 (oaspete:gazdă), raportul de masă al Fe ${ }_{3} \mathrm{O}_{4} @ H A @ A g$ și $\beta$-ciclodextrinei. S-au efectuat: spectroscopia în infraroșu cu transformata Fourier, analizele termogravimetrice și analizele de microscopie electronică cu scanare ale complecșilor preparați. Conform rezultatelor obținute, s-a observat că $\mathrm{Fe}_{3} \mathrm{O}_{4} @ H A @ A g$ formează în mod special complexul de incluziune cu $\beta$-ciclodextrina la un raport de masă de 1:2. În cea de-a doua parte a acestui studiu, sunt expuse rezultatele legate de utilizarea acestor complecși de incluziune în timpul procesului de electrofilare pentru a obține nanovăluri de fibre antibacteriene, care ar putea fi utilizate în cazul rănilor.

Cuvinte-cheie: $\beta$-ciclodextrină, complex de incluziune, Fe ${ }_{3} \mathrm{O}_{4} @ H A @ A g$, microscop electronic cu scanare

Inclusion complexes of $\beta$-cyclodextrine with $\mathrm{Fe}_{3} \mathrm{O}_{4} @ \mathrm{HA} @ \mathrm{Ag}$

Part I: Preparation and characterization

In this study, the preparation of inclusion complexes according to kneading and physical mixing techniques at 1:1 and 1:2 (guest:host) mass ratios of $\mathrm{Fe}_{3} \mathrm{O}_{4} @ H A @ A g$ and $\beta$-cyclodextrin were studied. Fourier transformed infrared spectroscopy, thermogravimetric analyses and scanning electron microscope analysesof the prepared complexes were carried out. According to the results obtained, it was observed $\mathrm{Fe}_{3} \mathrm{O}_{4} @ \mathrm{HA} @ A g$ especially forms inclusion complex with $\beta$-cyclodextrin at a mass ratio of 1:2. In the second part of this study, results related to the use of these inclusion complexes during electrospinning process in order to obtain antibacterial nanowebs, which could potentially be used in medical wounds, will be given.

Keywords: $\beta$-cyclodextrin, inclusion complex, $\mathrm{Fe}_{3} \mathrm{O}_{4} @ H A @ A g$, scanning electron microscope

\section{INTRODUCTION}

Cyclodextrins (CDs) obtained as a result of enzymatic degradation of starch are a member of cyclic oligosaccharides. They have a number of hydroxyl groups [1]. Details on the position of hydroxyl groups and the cavities can be found elsewhere [2-3]. There are a significant number of CDs however the most common ones are $\alpha-, \beta-$, and $\gamma-$ CDs. Greek letters $\alpha-, \beta-$, and $\gamma$ - designate the number of glucopyranose units in their structure [4-7]. Due to their cone-shaped hydrophobic cavity, CDs are good candidates to be used as a host for molecule encapsulations to form inclusion complexes (ICs) [8-9]. Abdel-Halim et al. used $\beta-C D$ as a host and loaded with octenidinedihydrochloride to form an IC which was then incorporated with a cotton fabric [10]. They investigated the antimicrobial property of IC-containing cotton fabric before and after each washes up to 20-wash. Inclusion complexes of CDs with different guest materials have been studied for a number of different applications [8, 11-13].

Silver and silver containing materials are widely studiedfor their antibacterial properties. Silver cyclohexane monocarboxylate (silver naphthenate), a product of naphthenic acid and silver salt reaction, was synthesized and its use as an antibacterial agent in textiles was investigated by Yildiz et al. [14]. A similar study was carried out on the synthesis of silver abietate to be used for antibacterial applications in textiles [15]. Silver and silver containing materials are also being used as the guest materials to form ICs with $\beta-C D$. Chen et al. used functionalized silver nanoparticles with $\beta-C D$ to make possible to detect aromatic isomers by naked eye [16]. Antibacterial activity of silver nanoparticles hosted by $\beta-C D$ was investigated by Andrade et al. together with structural and morphological characteristics of the inclusion complex [17].

Due to their electrical, magnetic and optical properties, magnetic nanomaterials have attracted the attention of researchers in recent years. These materials are good candidates for a number of applications. Role of $\mathrm{Fe}_{3} \mathrm{O}_{4}$ nanoparticles in biomedical applications was studied by Ghazanfari et al. [18] while magnetic nanocomposites consisting of $\mathrm{Fe}_{3} \mathrm{O}_{4}$, humic acid ( $\mathrm{HA})$ and silver $(\mathrm{Ag})$ was synthezied by Amir et al. [19] for the purpose of azo dye removal from waste water of textile industry. In this study, 
inclusion complexes containing $\mathrm{Fe}_{3} \mathrm{O}_{4} @ \mathrm{HA} @ \mathrm{Ag}$ and $\beta$-cyclodextrin (guest:host) with mass ratios of 1:1 and 1:2 were prepared by using kneading and physical mixing techniques. Prepared complexes were then analyzed under FTIR, TGA and SEM. In the second part of this study, results related to the addition of these prepared inclusion complexes in nanofiber production with electrospinning technique.

\section{EXPERIMENTAL WORK}

Inclusion complexes of $\beta$-cyclodextrin with $\mathrm{Fe}_{3} \mathrm{O}_{4} @ \mathrm{HA} @ \mathrm{Ag}$ were prepared according to the kneading technique at a mass ratio of 1:1 and 1:2. Mixtures of $\mathrm{Fe}_{3} \mathrm{O}_{4} @ \mathrm{HA} @ \mathrm{Ag}: \beta$-cyclodextrineat amass ratio of $1: 1$ and $1: 2$ by physical mixing technique were also prepared as reference. Mixing ratios and weights of the chemicals used in the inclusion complexes prepared are given in table 1 .

Table 1

\begin{tabular}{|c|c|}
\hline $\begin{array}{c}\text { MIXING RATIOS AND WEIGHTS USED IN KNEADING } \\
\text { AND PHYSICAL MIXING TECHNIQUES }\end{array}$ \\
\hline $\begin{array}{c}\text { Mass Ratio } \\
\text { (gram) }\end{array}$ & $\begin{array}{c}\mathrm{Fe}_{3} \mathrm{O}_{4} @ \text { HA@Ag: } \beta \text {-CD } \\
\text { (gram:gram) }\end{array}$ \\
\hline $1: 1$ & $0.113: 0.113$ \\
\hline $1: 2$ & $0.113: 0.226$ \\
\hline
\end{tabular}

The applications of kneading and physical mixing techniques are explained below.

\section{- Kneading technique}

In the kneading technique, firstly $1 \mathrm{~mL}$ of water was mixed with cyclodextrin. $\mathrm{Fe}_{3} \mathrm{O}_{4} @ \mathrm{HA} @ \mathrm{Ag}$ was added on the cyclodextrin, and they were kneaded together on the mortar for 20 minutes. The amounts of chemical and cyclodextrin used varied according to the mixing ratio.

\section{- Physical mixing technique}

Cyclodextrin and chemicals to be used was stirred in a flask at room temperature for 5 minutes with the help of baguette at room temperature. The amounts of chemical and cyclodextrin used varied according to the mixing ratio.

Once these studies were completed, characterization tests were carried out to check if inclusion complexes were formed. For this aim FTIR, SEM and TGA analyzes were performed.

Fourier transformed infrared spectroscopy (FTIR) analyses: Samples were measured using a Thermo brand fourier alternating infrared spectrophotometerover the range $500-4000 \mathrm{~cm}^{-1}$.

Scanning electron microscope (SEM) analyses: Quanta FEG 250 scanning electron microscope (FEI, Netherland) was employed for imaging of samples at a magnification of 1,000 .

Thermogravimetric analyses (TGA): Samples were measured using a Perkin Elmer DSC 4000 thermogravimetric analyzer.

\section{RESULTS AND DISCUSSION}

\section{FTIR results}

The shape, shift change of the IR absorption peaks of the guest or the host (cyclodextrin) gives information on the formation of the inclusion complex [20]. FT-IR spectra of pure $\beta-C D$, pure $\mathrm{Fe}_{3} \mathrm{O}_{4} @ \mathrm{HA} @ A$, physical mixtures and inclusion complexes prepared by kneading method both at $1: 1$ and $1: 2$ mass ratios are given in figure 1.

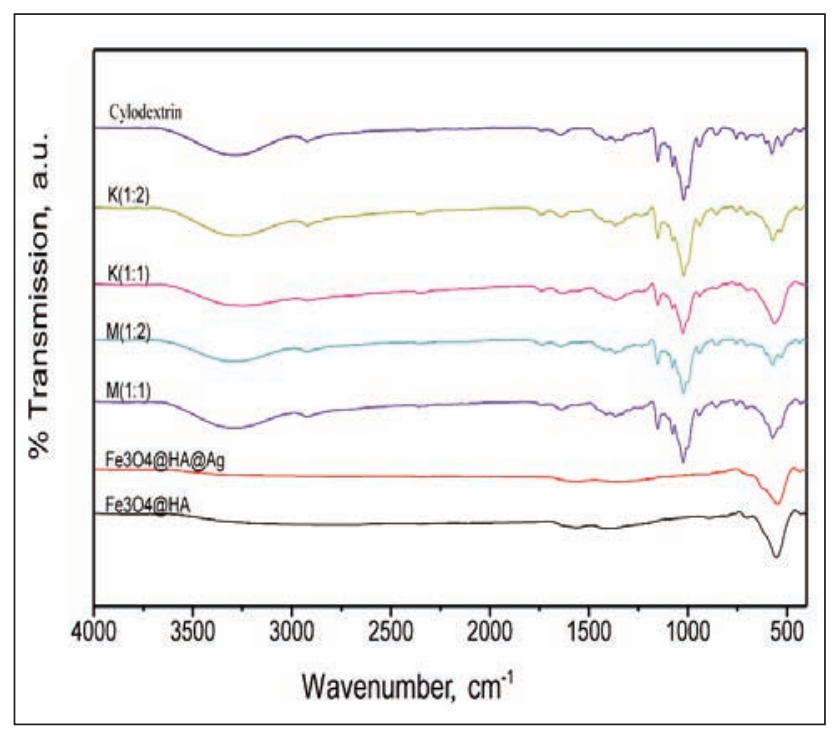

Fig. 1. FT-IR results of mixtures of $\mathrm{Fe}_{3} \mathrm{O}_{4} @ \mathrm{HA} @ \mathrm{Ag}$ prepared with $\beta-C D$ according to kneading and mixing techniques

As can be seen from figure $1, \beta-C D$ exhibited significant FT-IR peaks at wavelengths of 940 (skeletal vibrations involving $\alpha-1,4$ bonds), 1090 and 1160 (v (CO), v (CC), v (COH) peaks), $1340(\mathrm{H}-\mathrm{CH})$ peaks), $1420\left(\delta(\mathrm{CH})\right.$ peak from $\mathrm{CH}_{2}$ and $\left.\mathrm{CH}_{3}\right), 2930(\mathrm{v} \mathrm{CH}$ peak) and $3300 \mathrm{v}\left(-\mathrm{OH}\right.$ peak) $\mathrm{cm}^{-1}$ wavelengths [21]. When figure 1 is examined, it is understood that the both 1:1 or 1:2 inclusion complexes of $\mathrm{Fe}_{3} \mathrm{O}_{4} @ \mathrm{HA} @ \mathrm{Ag}$ and $\beta-C D$ differs significantly from the FTIR curves of pure $\mathrm{Fe}_{3} \mathrm{O}_{4} @ \mathrm{HA} @ \mathrm{Ag}$ and absorption bands of this inclusion complex is very similar with the pure $\beta-C D$. This indeed shows that the inclusion complex is formed and that significant shifts occur in its characteristic peaks due to the encapsulation of the $\mathrm{Fe}_{3} \mathrm{O}_{4} @ \mathrm{HA} @ A g$ in $\beta-C D$ cavity. These results actually indicate that there is some inclusion complex formation also in the physical mixing technique. When figure 1 is examined, it is noteworthy that complex preparation stoichiometry (1:1 and $1: 2)$ has significant effect on the results obtained. It can be said that $1: 2$ complexes of $\beta-C D$ with $\mathrm{Fe}_{3} \mathrm{O}_{4} @ \mathrm{HA} @ A g$ gives better results.

\section{TGA results}

Thermograms of pure $\beta-C D$, pure $\mathrm{Fe}_{3} \mathrm{O}_{4} @ \mathrm{HA} @ A g$, theirphysical mixtures and inclusion complexes prepared by kneading method both at $1: 1$ and $1: 2$ mass ratios are given in figure 2 . 


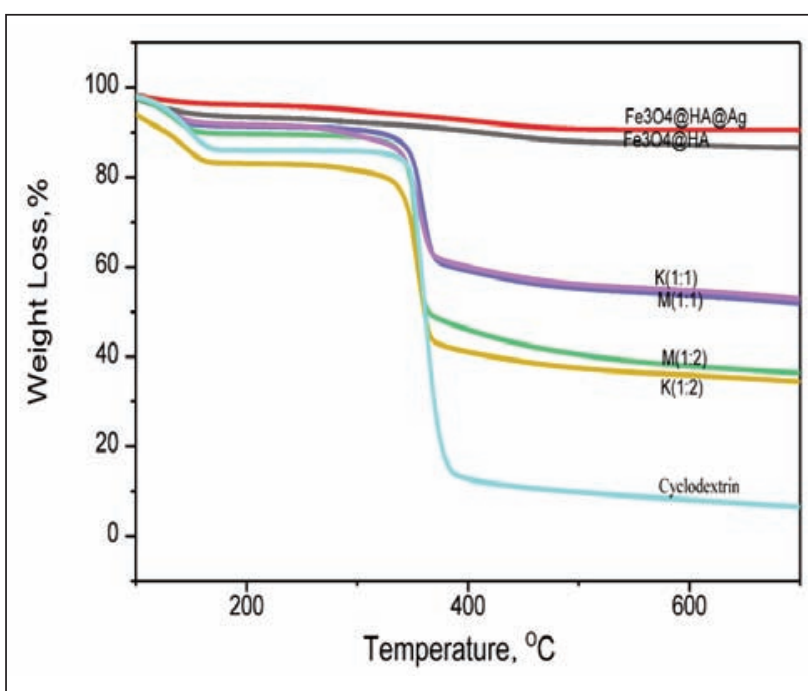

Fig. 2. TGA results of mixtures of $\mathrm{Fe}_{3} \mathrm{O}_{4} @ \mathrm{HA} @ \mathrm{Ag}$ prepared with $\beta-C D$ according to kneading and mixing techniques

When figure 3 is examined, it is understood that the both 1:1 or 1:2 inclusion complexes of $\mathrm{Fe}_{3} \mathrm{O}_{4} @ \mathrm{HA} @ \mathrm{Ag}$ with $\beta-C D$ differs significantly from the thermograms of $\mathrm{Fe}_{3} \mathrm{O}_{4} @ \mathrm{HA} @ \mathrm{Ag}$ and absorption bands of these inclusion complexes are very similar with the pure $\beta-C D$. When the thermograms are examined, it can be seen that the thermal degradation result in pure $\beta-C D$ causes a sharp mass loss at about $350^{\circ} \mathrm{C}$. Normally, the thermal disruption of pure $\mathrm{Fe}_{3} \mathrm{O}_{4} @ \mathrm{HA} @ \mathrm{Ag}$ does not result in a sharp mass loss, but a sharp mass loss at around $300^{\circ} \mathrm{C}$ occurs for their inclusion complexes with $\beta-C D$. This indeed shows that the inclusion complexes are formed and due to the encapsulation of $\mathrm{Fe}_{3} \mathrm{O}_{4} @ \mathrm{HA} @ \mathrm{Ag}$, significant shift in their heat distortion curves occurred.

\section{SEM results}

SEM analysis is ideal for measuring the surface roughness of the material and for visualizing surface texture [22]. For this reason, SEM photographs were taken for pure substances and prepared mixtures. SEM photos of pure $\beta-C D$, pure $\mathrm{Fe}_{3} \mathrm{O}_{4} @ \mathrm{HA} @ A g$, their physical mixtures and inclusion complexes prepared by kneading method both at $1: 1$ and $1: 2$ mass ratios are given in figure 3 .

SEM photographs of $\mathrm{Fe}_{3} \mathrm{O}_{4} @ \mathrm{HA} @ A g: \beta-C D$ complexes given in figure 3 show that both components are transformed into a collection of irregularly shaped

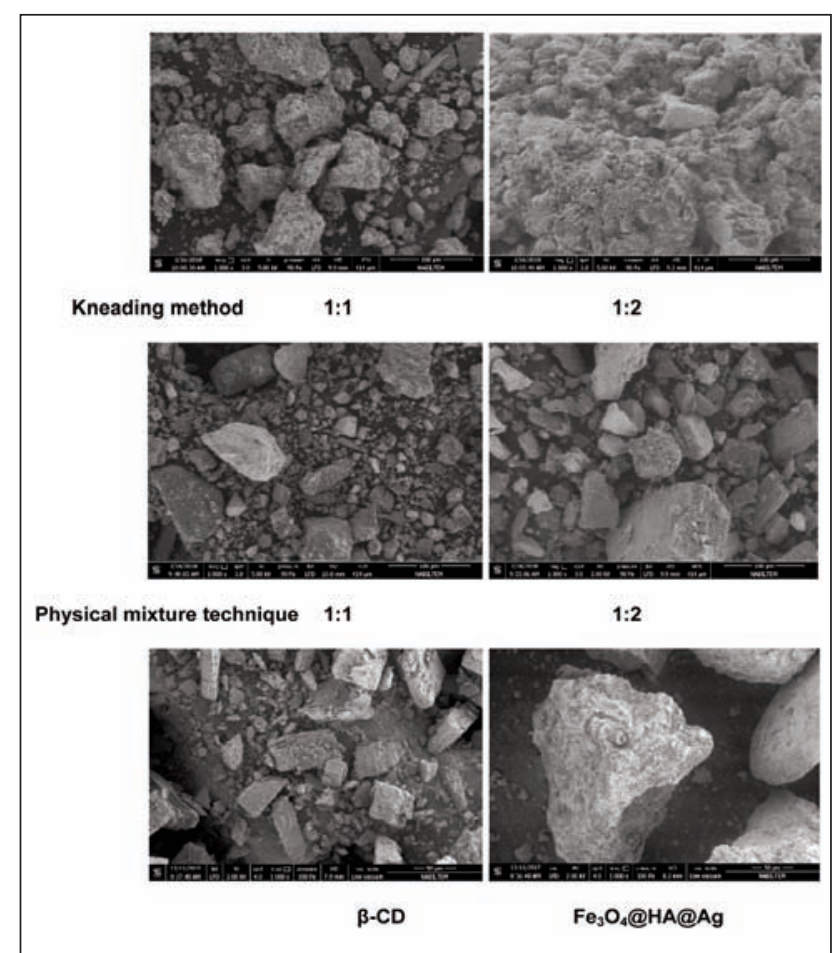

Fig. 3. SEM photos of mixtures of $\mathrm{Fe}_{3} \mathrm{O}_{4} @ \mathrm{HA} @ \mathrm{Ag}$ prepared with $\beta-C D$ according to kneading and mixing techniques $(\mathrm{X} 1,000)$

amorphous particles in which the original morphology disappeared [23].

\section{CONCLUSION}

In this study, the preparation of inclusion complexes according to kneading and physical mixing techniques at 1:1 and 1:2 (guest:host) mass ratios of $\mathrm{Fe}_{3} \mathrm{O}_{4} @ \mathrm{HA} @ \mathrm{Ag}$ and $\beta$-cyclodextrin was studied. FTIR, TGA and SEM analyzes of the prepared complexes were carried out. According to the results obtained, it was found that $\mathrm{Fe}_{3} \mathrm{O}_{4} @ \mathrm{HA} @ \mathrm{Ag}$ especially forms inclusion complex with $\beta$-cyclodextrin at a mass ratio of 1:2. As Electrospinning is one of the most widely used techniques in the $21^{\text {st }}$ century, due to its adaptability and potential for applications in various domains, such as: wound healing, artificial skin, membranes for selective separation, target delivery system for active agents and molecules, scaffolds for tissue or bone engineering [24], in the second part of this study, results related to the use of these inclusion complexes during electrospinning process in order to obtain antibacterial nanofibers will be given.

\section{BIBLIOGRAPHY}

[1] Folch-Cano, C., Yazdani-Pedram, M., Olea-Azar, C. Inclusion and functionalization of polymers with cyclodextrins: Current applications and future prospects, In: Molecules, 2014, vol. 19, pp. 14066-14079.

[2] Miranda, J.C., Martins, T.E.A., Veiga F., Ferraz H.G. Cyclodextrins and ternary complexes: technology to improve solubility of poorly soluble drugs, In: Brazilian Journal of Pharmaceutical Sciences, 2011, vol. 47, pp. 665-681.

[3] Sliwa, W., Girek, T. Cyclodextrins properties and applications, Wiley-VCH Publishing, Germany, 2017.

[4] Davis, M.E., Brewster, M.E. Cyclodextrin-based pharmaceutics: past, present and future, In: Nat. Rev. Drug. Discov., 2004, vol. 3, no. 12, pp. 1023-1035. 
[5] Radu, C.-D., Parteni. O., Ochiuz, L. Applications of cyclodextrins in medical textiles - review, In: Journal of Controlled Release, 2016, vol. 224, pp. 146-157.

[6] lacovino, R., Caso, J.V., Donato, C.D., Malgieri, G., Palmieri, M., Russo, L., Isernia, C. Cyclodextrins as complexing agents: preparation and applications, In: Current Organic Chemistry, 2017, vol. 21, pp. 162-176.

[7] Wadhwa, G., Kumar, S., Chhabra, L., Mahant, S., Rao, R. Essential oil-cyclodextrin complexes: an updated review, In: Journal of Inclusion Phenomena and Macrocyclic Chemistry, 2017, vol. 89, pp. 39-58.

[8] Pinho. E., Grootveld. M., Soares. G., Henriques. M. Cyclodextrins as encapsulation agents for plant bioactive compounds, In: Carbohydrate Polymers, 2014, vol. 101, pp. 121-135.

[9] Attarchi, N., Montazer, M., Toliyat, T., Samadi, N., Harifi, T. Novel cellulose fabric with multifunctional properties through diverse methods of $\mathrm{Ag} / \mathrm{TiO}_{2} / \mathrm{b}$-cyclodextrin nanocomposites synthesis, In: Cellulose, 2018, vol. 25, pp. 1449-1462.

[10] Abdel-Halim, E.S., Al-Deyab, S.S., Alfaifi, A.Y.A. Cotton fabric finished with $\beta$-cyclodextrin: Inclusion ability toward antimicrobial agent, In: Carbohydrate Polymers, 2014, vol. 102, pp. 550-556.

[11] Mangolim, C.S., Moriwaki, C., Nogueira, A.C., Sato, F., Baesso, M.L., Neto, A.M., Matioli, G. Curcumin- $\beta$ cyclodextrin inclusion complex: Stability, solubility, characterisation by FT-IR, FT-Raman, X-ray diffraction and photoacoustic spectroscopy, and food application, In: Food Chemistry, 2014, vol. 153, pp. 361-370.

[12] Saha, S., Roy, A., Roy, K., Roy, M.N. Study to explore the mechanism to form inclusion complexes of $\beta$-cyclodextrin with vitamin molecules, In: Scientific Reports, 2016, vol. 6, Article ID 35764.

[13] Celebioglu, A., Yildiz, Z.I., Uyar, T. Fabrication of electrospun eugenol/cyclodextrin inclusion complex nanofibrous webs for enhanced antioxidant property, water solubility, and high temperature stability, In: Journal of Agricultural and Food Chemistry, 2018, vol. 66, pp. 457-466.

[14] Yildiz, A., Atav, R., Oztas, M., Ağirgan, A.Ö., Gülen, D., Aydin, M., Yeşilyurt, M., Kaya, A.D. Synthesis of silver monoand di-carboxylates and investigation of their usage possibility in textiles as an antibacterial agent, In: Fibres \& Textiles in Eastern Europe, 2015, vol. 23, pp. 120-125.

[15] Yıldız, A., Değirmencioğlu, M. Synthesis of silver abietate as an antibacterial agent for textile applications, In: Bioinorganic Chemistry and Applications, 2015, vol. 2015, Article ID 215354.

[16] Chen, X., Parker, S.G., Zou, G., Su, W., Zhang, Q. $\beta$-cyclodextrin-functionalized silver nanoparticles for the naked eye detection of aromatic isomers, In: ACS Nano, 2010, vol. 4, pp. 6387-6394.

[17] Andrade, P.F., de Faria, A.F., da Silva, D.S., Bonacin, J.A., Gonçalves, Mdo C. Structural and morphological investigations of $\beta$-cyclodextrin-coated silver nanoparticles, In: Colloids Surf B Biointerfaces, 2014, vol. 118, pp. 289-297.

[18] Ghazanfari, M.R., Kashefi, M., Shams, S.F., Jaafari, M.R. Perspective of $\mathrm{Fe}_{3} \mathrm{O}_{4}$ nanoparticles role in biomedical applications, In: Biochemistry Research International, 2016, vol. 2016, Article ID 7840161.

[19] Amir, Md., Güner, S., Yıldız, A., Baykal, A. Magneto-optical and catalytic properties of $\mathrm{Fe}_{3} \mathrm{O}_{4} @ H A @ A g$ magnetic nanocomposite, In: Journal of Magnetism and Magnetic Materials, 2017, vol. 421, pp. 462-471.

[20] Al Omari, M.M., Daraghmeh, N.H., El-Barghouthi, M.I., Zughul, M.B., Chowdhry, B.Z., Leharne, S.A., Badwan, A.A. Novel inclusion complex of ibuprofen tromethamine with cyclodextrins: Physico-chemical characterization, In: J. Pharm. Biomed. Anal., 2009, vol. 50, pp. 449-458.

[21] Norasiha, H., Mimi, Sakinah, A.M., Rohaida, C.M. Characterization of $\beta$-cyclodextrın complexes with natural dye, In: National Conference on Postgraduate Research (NCON-PGR), 2009, Malaysia.

[22] Srinivasan, K., Sivakumar, K., Stalin, T. 2,6-Dinitroaniline and $\beta$-cyclodextrin inclusion complex properties studied by different analytical methods, In: Carbohydr. Polym., 2014, vol. 113, pp. 577-587.

[23] Yadav, V.R., Suresh, S., Devi, K., Yadav, S. Effect of cyclodextrin complexation of curcumin on its solubility and antiangiogenic and anti-inflammatory activity in rat colitis model, In: AAPS PharmSciTech, 2009, vol. 10, pp. 752-762.

[24] Subtirica, A.I., Banciu, C.A., Chivu, A.A.-M., Dinca, L.-C. Nanofibres made from biocompatible and biodegradable polymers, with potential application as medical textiles, In: Industria Textila, 2018, vol. 69, no. 1, pp. 55-58.

Authors:
Prof. Dr. RIZA ATAV
Assoc. Prof. Dr. AYLIN YILDIZ
Assoc. Prof. Dr. DERMAN VATANSEVER BAYRAMOL
Dr. AHMET ÖZGÜR AĞIRGAN
Namık Kemal University, Department of Textile Engineering, Corlu-Tekirdag, Turkey
e-mail: ratav@nku.edu.tr
Corresponding author:
RIZA ATAV
e-mail: ratav@nku.edu.tr




\title{
Optimization of coating parameters for air permeability of denim fabrics through Taguchi method
}

\author{
DOI: $10.35530 / I T .070 .03 .1564$
}

\section{REZUMAT - ABSTRACT}

\section{Optimizarea parametrilor de acoperire pentru permeabilitatea la aer a țesăturilor denim prin metoda Taguchi}

Tehnologia de acoperire este o metodă din ce în ce mai populară pentru crearea unor modele speciale și obținerea unui aspect diferit al țesăturilor denim. În funcție de proprietățile așteptate din partea țesăturilor denim, parametrii de proces ai acoperirii pot fi modificați. Este important modul în care parametrii procesului afectează caracteristicile de confort ale țesăturilor denim. Prezentul studiu are ca scop optimizarea diferiților parametri ai procesului de acoperire pentru proprietățile de permeabilitate la aer ale țesăturilor denim, folosind metoda Taguchi. Parametrii selectați pentru optimizare sunt presiunea de stoarcere, viscozitatea fluidului de acoperire, viteza de trecere a țesăturii, temperatura de uscare și desimea firelor de bătătură ale țesăturilor. Un model ortogonal L27 $\left(3^{5}\right)$ a fost ales ca plan experimental. În evaluările cu metoda Taguchi au fost utilizate analize ale raportului semnal-zgomot (S/N) și varianță (ANOVA). Rezultatele arată că desimea firelor de bătătură și viscozitatea au o influență semnificativă asupra proprietăților de permeabilitate la aer a țesăturilor denim acoperite.

Cuvinte-cheie: țesătură denim, acoperire, permeabilitate la aer, metoda Taguchi, raport S/N

\section{Optimization of coating parameters for air permeability of denim fabrics through Taguchi method}

Coating technology is an increasingly popular method for creating special designs and getting different appearance to denim fabrics. Depending on the expected properties from denim fabrics, the process parameters of coating can be changed. It is important issue how process parameters affect the comfort characteristics of denim fabrics. The present study is aimed at optimizing the various coating process parameters for the air permeability properties of denim fabrics by using Taguchi method. The parameters selected for optimization are squeeze pressure, viscosity of coating fluid, fabric passing speed, drying temperature and weft density of fabrics. An $L 27\left(3^{5}\right)$ orthogonal design was chosen as experimental plan. In the evaluations with Taguchi Method, analyses of the signal to noise ratio (S/N) and variance (ANOVA) were used. The results show that weft density and viscosity have significant influence on the air permeability properties of coated denim fabrics.

Keywords: denim fabric, coating, air permeability, Taguchi method, S/N ratio

\section{INTRODUCTION}

Denim has been widely acknowledged by all the age group throughout the world for many years. High durability, longer washing cycle and its ability to adapt to changing fashion trends and demands have made it most popular garment in the international market. Depending on growth and change in demand for denim products, denim fabric manufacturers constantly try to develop novel varieties of denim fabrics by various methods to meet consumer demands.

Fabric finishing is the last stage in the production of denim and it is where the final touch is added, and it can make a big difference in how the fabric looks, feels and wears. There are countless dry and wet finishing processes in denim garment processing like washing, bleaching, printing, coating etc. Coating is an important process for covering the surface of denim fabric with chemicals or dyestuffs in order to improve various surface properties such as waxy, oily, glossy, paper, leather, silicone, etc. Coating materials can be waxes, rubbers, latex, plastic films, resins, polyurethanes, binders or metal powders. Today several coating layers can be applied to denim fabrics to obtain different visual effects after washing treatment. In general, knife, foam and rotary screen coating methods are used to coat denim fabrics [1-4]. When considering the coating of fabrics like denim, breathability of the fabric is essential along with performance and aesthetic properties. Therefore, air permeability is an important factor in determining the comfort level of a coated fabric as it plays a significant role in transporting moisture vapors from the skin to the outside atmosphere [5]. It is thought that many parameters of coating process may affect the air permeability of the coated fabrics. Without a scientific approach, it is very difficult to assess these parameters in mill conditions. At the same time, it is quite exhaustive to determine the effects of all process parameters affecting air permeability of coated fabrics with full factorial design, because it requires a wide range of experiments, which extremely increase the experimental period and cost [6].

The present study is focused on optimizing the various coating process parameters for the air permeability properties of denim fabrics by using Taguchi's experimental design technique, a leading optimization technique reducing the experimental period and cost. Taguchi method provides the means to minimize 
the variability of products and processes in order to improve their quality and reliability. This particular design methodology has been successfully employed in a wide variety of fields, including textile engineering [7].

Yang at al. investigated the optimization of the printing process using the Taguchi method. To determine the optimum conditions for color strength and fastness, two types of multiple characteristic parameter design methods were used, including the single characteristic value conversion method and the minimummaximum selection method. As a result, the single characteristic value conversion method was proved to be more efficient compared to the minimum-maximum selection method [8]. Three factors, i.e. elastane linear density, fabric thread density and weave float were investigated by Maqsood at al. in terms of air permeability, stretch \% and recovery \% along warp and weft, using grey relational method. They found that by increasing elastane count (dtex), fabric stretch \% along warp, fabric warp-way and weft-way recovery increases, whereas fabric air permeability and stretch \% along weft decrease [9]. Nassif studied the optimization of the fabric parameters influencing the woven cotton fabrics' air permeability. As conducting the cause and effect diagram, weft yarn count, weft yarn twist factor and weft yarn density were determined as control factors influencing woven fabrics' air permeability. It was observed that the weft yarn density was the most important control factor influencing fabric air permeability followed by weft yarn count [10]. Ahmad at al. investigated the optimization of water and oil repellent finishing of cotton fabric using Taguchi based grey relational analysis. They found that the concentration of Oleophobol CPC was the most significant factor (42\%) followed by curing temperature (38\%) and the cross-linking agent Knittex FEL concentration (15\%) [11]. Mavruz and Ogulata analyzed the effect of certain yarn and fabric parameters on the bursting strength of knitted fabric, using Taguchi orthogonal design. Relaxation treatment, yarn type and loop length were chosen as the control parameters. They found that the contribution of different factors in a decreasing order was as follows: yarn type $(62.44 \%)$, relaxation treatment (34.39\%), loop length (1.63\%) and undefined parameters $(1.54 \%)$ [12]. Shabaridharan and Das studied the effect of different types of coated fabric on thermal properties of multilayered fabrics consisting of knitted fabric and through air-bonded nonwovens. Also, they analyzed the effect of pore size and porosity on thermal and evaporative resistances of coated fabrics. It was found that the mass per unit area of through air-bonded nonwoven and pore size of coated fabric were found to have significant effect on thermal and evaporative resistances of multilayered fabric ensembles [13].

\section{Fundamentals of Taguchi method}

Taguchi method is a unique and powerful optimization discipline that allows optimization with minimum number of experiments. The advantages of Taguchi method over the other methods are that numerous factors can be simultaneously optimized and more quantitative information can be extracted from fewer experimental trials [14]. Taguchi involves the stages of system design, parameters design, and tolerance design. In system design, the engineer applies scientific and engineering knowledge to produce a basic functional prototype design, this design including the product design stage and the process design stage. Since system design is an initial functional design, it may be far from optimum in terms of quality and cost. The objective of parameter design is to optimize the settings of the process parameter values for improving quality characteristics and to identify the product parameter values under the optimal process parameter values. Finally, tolerance design is used to determine and analyze tolerances in the optimal settings recommended by parameter design [6, 15-19].

Two major tools used in Taguchi's method are the orthogonal array $(\mathrm{OA})$ and the signal-to-noise ratio ( $\mathrm{S} / \mathrm{N}$ ratio). OA, which determines the optimum level for each factor and establishes the relative significance of the individual factors in terms of their main effects on the response is a matrix of numbers arranged in rows and columns. $S / N$ ratio $(\eta)$ expressed in decibels $(\mathrm{dB})$ is indicative of quality and the purpose of the Taguchi experiment is to find the best level for each operating parameter so as to maximize (or minimize) $S / N$ ratio [12, 15, 20-21].

The Taguchi method, depending on the objective, proposed three categories of quality characteristics in the analysis of $S / N$ ratio, which are nominal-the-better, larger-the-better and smaller-the-better. The three different signal-noise ratios, corresponding to $n$ experiments, are presented below:

Nominal-the-better:

$$
\begin{aligned}
S / N & =-10 \log \left[\frac{1}{n} \sum_{i=1}^{n}\left(y_{i}-m\right)^{2}\right]= \\
& =-10 \log \left[(\bar{y}-m)^{2}+S^{2}\right]
\end{aligned}
$$

Larger-the-better

$$
S / N=-10 \log \left[\frac{1}{n} \sum_{i=1}^{n} \frac{1}{y_{i}^{2}}\right]=
$$

Smaller-the-better

$$
S / N=-10 \log \left[\frac{1}{n} \sum_{i=1}^{n} y_{i}^{2}\right]=-10 \log \left(\bar{y}^{2}\right)
$$

where $S$ denotes the standard deviation; $y_{i}-$ the data obtained from experiments; $n$ represents the number of experiments [5]. Regardless of the category of the quality characteristic, a greater $S / N$ ratio corresponds to better quality characteristics.

Taguchi methodology for optimization can be divided into four phases: planning, conducting, analysis and validation. Each phase has a separate objective and contributes towards the overall optimization process [5]. To summarize, the parameter design of the Taguchi method includes the following steps: (1) define the problem and the objective; (2) identification of control factor and levels; (3) selection of the appropriate 
orthogonal array and assignment of design parameters to the orthogonal array; (4) conducting of the experiments based on the arrangement of the orthogonal array; (5) analysis of the experimental results using the S/N and ANOVA analyses; (6) selection of the optimal levels of design parameters; and (7) verification of the optimal design parameters through the confirmation experiment [15].

\section{MATERIALS AND METHODS}

Taguchi parameter design analysis was performed with Minitab Version 16.0 software package that is a computer program designed to perform basic and advanced statistical functions. In this study; squeeze pressure, viscosity of coating fluid, fabric passing speed, drying temperature and weft density were selected as control factors affecting the air permeability of denim fabrics. After determining the control factors, the levels of each factor were determined. Each of the control factors was evaluated with three levels. The working conditions of coating machine were taken into consideration in order to determine the factors and levels. The five process parameters or factors for convenience are represented by the letters A-E. The factors (A-E) and levels of each factor are listed in table 1.

Table 1

\begin{tabular}{|c|c|c|c|c|}
\hline \multicolumn{5}{|c|}{$\begin{array}{c}\text { CONTROL FACTORS AND LEVELS FOR } \\
\text { THE EXPERIMENTAL DESIG }\end{array}$} \\
\cline { 3 - 5 } Code & \multirow{2}{*}{ Factors } & $\mathbf{3}$ & $\mathbf{2}$ & $\mathbf{3}$ \\
\hline A & Weft density (picks/cm) & 14 & 17 & 20 \\
\hline B & Drying temperature $\left({ }^{\circ} \mathbf{C}\right)$ & 120 & 140 & 160 \\
\hline C & Viscosity (dPa.s) & 30 & 50 & 70 \\
\hline D & Squeeze pressure (bar) & 3 & 5 & 7 \\
\hline E & Fabric passing speed (m/min) & 10 & 20 & 30 \\
\hline
\end{tabular}

In this study, an L27 $\left(3^{5}\right)$ OA table was selected, as shown in table 2 . With five factors, each having three levels, a total of $243\left(3^{5}\right)$ full factorial experiments would be required to explore all possible factor-level combinations and, the cost and effort of such experiments would be quite large. However, with this experimental design of L27 $\left(3^{5}\right)$ OA, only 27 experiments were required.

After determining the control factors and their levels, three denim fabric samples were manufactured with 3/1 Z twill structure. Ne 8.2/1 ring yarns were used as the warp yarn with a density of 17 ends/cm for all fabric samples. The weft density of the denim fabrics was used as control parameter and $\mathrm{Ne} 10.4 / 1$ ring core-spun yarns (\%95 cotton and \%5 Elastane-70 dtex) were used as weft yarn with three different density $(14,17$ and 20 picks $/ \mathrm{cm})$. The coating of the denim fabrics was applied by the Rotary Screen Coating Method, which is the deposition of a coating material on a substrate through a mesh screen by squeezing. A standard coating pat used in the mill was used for the coating of the denim fabrics.
All coated denim samples were conditioned for $24 \mathrm{~h}$ at $20^{\circ} \mathrm{C}$ and $65 \%$ relative humidity prior to air permeability testing. Air permeability of the coated denim fabrics were evaluated according to the CSN EN ISO 9237 standard, using the Textest FX 3300 air permeability tester at a constant pressure drop of $100 \mathrm{~Pa}$ (20 $\mathrm{cm}^{2}$ test area). Ten samples were tested each sample and expressed as $\mathrm{mm} / \mathrm{s}$.

In determining the optimum coating conditions for air permeability of denim fabrics, Taguchi's parameter design approach was used to plan, analyze, and confirm the experiments. First, it was calculated the $S / N$ ratios of repeated experimental results obtained from the experimental design using L27 orthogonal array. Then, it was determined the optimum level for each of the coating parameters. Next, a statistical analysis of variance (ANOVA) was performed to see which process parameters are statistically significant. Finally, improving rate obtained from using optimum factor levels was calculated by compared to the selected initial design.

\section{RESULTS AND DISCUSSION}

In the Taguchi optimization method, analysis of response depends upon whether smaller or larger value of the response is desired. In this study, the air permeability was classified under the response type "larger is better", because the high value of air permeability is a desirable feature in terms of comfort. The formula used for the calculation of the $S / N$ ratio is given (2) in the introduction of the paper and the calculated $S / N$ ratios for air permeability are given in table 2.

In the Taguchi method, another step is to determine the average effect of each factor on the multiple quality characteristic at different levels. This is equal to the sum of all $S / N$ ratios corresponding to a factor at a particular level divided by the number of repetitions of the factor level [5]. The factor levels corresponding to the maximum average effect are selected as the optimum level. For air permeability values of coated denim fabrics, the average factor effect is shown in table 3 , and the main effects plotted for $S / N$ ratio are shown in figure 1 . The delta value (table 3 ) was calculated by subtracting the largest value from the

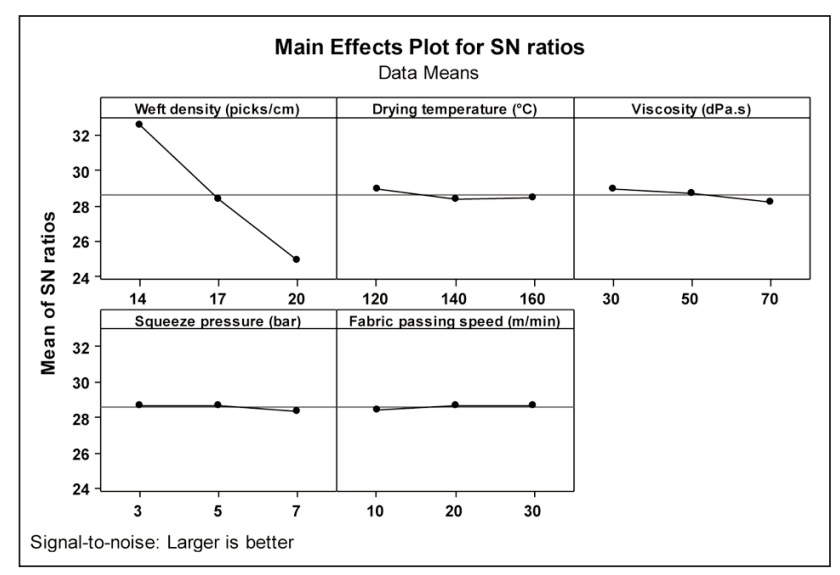

Fig. 1. Main effects plot for $\mathrm{S} / \mathrm{N}$ of air permeability output 


\begin{tabular}{|c|c|c|c|c|c|c|c|}
\hline \multicolumn{8}{|c|}{$\begin{array}{l}\text { EXPERIMENTAL LAYOUT USING AN L }{ }_{27}\left(3^{5}\right) \\
\text { ORTHOGONAL ARRAY TABLE }\end{array}$} \\
\hline \multirow{2}{*}{ Order } & \multicolumn{5}{|c|}{ Parameters } & \multirow{2}{*}{$\begin{array}{l}\text { Average air } \\
\text { permeability } \\
\text { value, } \mathrm{mm} / \mathrm{s}\end{array}$} & \multirow{2}{*}{$\begin{array}{l}\mathrm{S} / \mathrm{N} \text { ratio, } \\
\mathrm{dB}\end{array}$} \\
\hline & A & B & C & D & E & & \\
\hline 1 & 1 & 1 & 1 & 1 & 1 & 45.18 & 33.06 \\
\hline 2 & 1 & 1 & 1 & 1 & 2 & 45.32 & 33.10 \\
\hline 3 & 1 & 1 & 1 & 1 & 3 & 49.12 & 33.79 \\
\hline 4 & 1 & 2 & 2 & 2 & 1 & 40.19 & 32.07 \\
\hline 5 & 1 & 2 & 2 & 2 & 2 & 43.09 & 32.65 \\
\hline 6 & 1 & 2 & 2 & 2 & 3 & 43.36 & 32.73 \\
\hline 7 & 1 & 3 & 3 & 3 & 1 & 35.28 & 30.92 \\
\hline 8 & 1 & 3 & 3 & 3 & 2 & 40.39 & 32.11 \\
\hline 9 & 1 & 3 & 3 & 3 & 3 & 42.10 & 32.46 \\
\hline 10 & 2 & 1 & 2 & 3 & 1 & 27.60 & 28.72 \\
\hline 11 & 2 & 1 & 2 & 3 & 2 & 26.91 & 28.53 \\
\hline 12 & 2 & 1 & 2 & 3 & 3 & 26.79 & 28.47 \\
\hline 13 & 2 & 2 & 3 & 1 & 1 & 23.31 & 27.33 \\
\hline 14 & 2 & 2 & 3 & 1 & 2 & 24.83 & 27.82 \\
\hline 15 & 2 & 2 & 3 & 1 & 3 & 26.77 & 28.53 \\
\hline 16 & 2 & 3 & 1 & 2 & 1 & 26.33 & 28.39 \\
\hline 17 & 2 & 3 & 1 & 2 & 2 & 28.59 & 29.10 \\
\hline 18 & 2 & 3 & 1 & 2 & 3 & 25.96 & 28.25 \\
\hline 19 & 3 & 1 & 3 & 2 & 1 & 19.74 & 25.86 \\
\hline 20 & 3 & 1 & 3 & 2 & 2 & 17.25 & 24.72 \\
\hline 21 & 3 & 1 & 3 & 2 & 3 & 16.28 & 24.22 \\
\hline 22 & 3 & 2 & 1 & 3 & 1 & 17.59 & 24.90 \\
\hline 23 & 3 & 2 & 1 & 3 & 2 & 17.73 & 24.97 \\
\hline 24 & 3 & 2 & 1 & 3 & 3 & 16.81 & 24.50 \\
\hline 25 & 3 & 3 & 2 & 1 & 1 & 17.02 & 24.61 \\
\hline 26 & 3 & 3 & 2 & 1 & 2 & 17.94 & 25.06 \\
\hline 27 & 3 & 3 & 2 & 1 & 3 & 18.33 & 25.25 \\
\hline
\end{tabular}

lowest from among the values in each row. A higher delta value means that the difference at the selected level for a given factor is highly pronounced and, in turn, the level change of this factor has an impact on the air permeability properties of coated denim fabric. Based on the $S / N$ ratios, the most effective input parameter is weft density (A) and second effective
RESPONSE TABLE FOR THE S/N RATIO OF AIR PERMEABILITY OUTPUT

\begin{tabular}{|c|c|c|c|c|c|}
\hline \multirow{2}{*}{ Factors } & \multicolumn{5}{|c|}{ Average S/N, dB } \\
\cline { 2 - 6 } & Level 1 & Level 2 & Level 3 & Delta & Rank \\
\hline A & $32.54^{*}$ & 28.35 & 24.90 & 7.64 & 1 \\
\hline B & $28.94^{*}$ & 28.39 & 28.46 & 0.55 & 3 \\
\hline C & $28.89^{*}$ & 28.68 & 28.22 & 0.68 & 2 \\
\hline D & $28.73^{*}$ & 28.67 & 28.40 & 0.33 & 4 \\
\hline E & 28.43 & 28.67 & $28.69^{*}$ & 0.26 & 5 \\
\hline
\end{tabular}

* Optimum parameter level

input parameter is viscosity $(C)$. The highest level of weft density (A) factor is at level 1 and air permeability value decrease with the increasing weft density, as expected (figure 1). This decrease in air permeability may be attributed to the decreasing pore size which depends on the increasing of weft density. Also, the highest level of viscosity factor $(C)$ is at level 1 and air permeability value decrease with the increasing viscosity. In another word, the viscosity increase negatively affects the air permeability values of the fabrics. The combination satisfying the maximum air permeability value (A1B1C1D1E3) was determined by choosing the highest $S / N$ ratio for each factor.

The analysis of variance (ANOVA) is performed on $S / N$ ratios to see which process parameters are statistically significant and to obtain the percentage contribution of each of the factors. The contribution ratio is calculated from the ratio of the sum of squares (SS) of each factor to total SS value. The bigger this value on the output of that parameter is understood to be effective at that rate. Table 4 lists the analysis of variance for $S / N$ ratio of air permeability and the contribution ratio of each parameter to air permeability. In the table, weft density (A), has the highest value of $96.6 \%$ in contribution and this factor has significant effect on the air permeability properties of coated denim fabrics. A small variation for the weft density factor with a high percent contribution will have a great influence on the air permeability. Also, viscosity (C) parameter has significant effect on the air permeability values of coated denim fabric and the contribution of viscosity value is $0.79 \%$ for air

ANOVA TABLE FOR S/N RATIO OF AIR PERMEABILITY OUTPUT

\begin{tabular}{|c|c|c|c|c|c|c|}
\hline Factor & df & Sum of squares & Mean square & F-value & P & Percentage contribution (\%) \\
\hline A & 2 & 263.767 & 131.883 & 474.00 & 0.000 & 96.6 \\
\hline B & 2 & 1.631 & 0.815 & 2.93 & 0.082 & 0.59 \\
\hline C & 2 & 2.154 & 1.077 & 3.87 & 0.043 & 0.79 \\
\hline D & 2 & 0.553 & 0.277 & 0.99 & 0.392 & 0.20 \\
\hline E & 2 & 0.384 & 0.192 & 0.69 & 0.516 & 0.14 \\
\hline Residual & 16 & 4.452 & 0.278 & & & 0.63 \\
\hline Total & 26 & 272.941 & & & & \\
\hline
\end{tabular}


permeability output. Furthermore, it can be seen that the ANOVA has resulted in around $0.63 \%$ of error contribution due to interaction effect. Thus, the optimization is also affected by the interaction between the factors.

\section{Confirmation test for air permeability output}

The confirmation experiment is the final step of the design of an experiment. The purpose of the confirmation experiment is to predict and verify the conclusions drawn during the analysis phase. The confirmation experiment is performed by conducting a test with optimal settings of the factors and levels previously evaluated [22]. The predicted value of the multiple $S / N$ ratio at the optimum level is calculated as:

$$
\eta_{0}=\eta_{m}+\sum_{i=1}^{j}\left(\eta_{i}-\eta_{m}\right)
$$

where, $\eta_{m}$ is total mean of $S / N$ ratio, $j$ - the number of factors, and $\eta_{i}-$ the multiple $S / N$ ratios corresponding to optimum factor levels. The predicted $S / N$ ratio of optimum design is found to be $33.39 \mathrm{~dB}$ for air permeability. If the $S / N$ is known and we want to learn about the result expected that will make the $S / N$, the procedure is to back-transform $S / N$ to find the performance value expected [12]. When the predicted $S / N$ was placed into Formula 2, the predicted air permeability values of the optimum design was obtained as $46.07 \mathrm{~mm} / \mathrm{s}$.

The confirmation experiment was not performed with optimum combination (A1B1C1D1E3), since this combination is in the experiment design (table 2). As shown in table 2, the $S / N$ and average air permeability value for optimum conditions are 33.79 and 49.12 , respectively. These results are very close to that predicted by Taguchi design. Table 5 shows the comparison of the predicted air permeability with the experimental air permeability using the optimal coating parameters.

The confidence interval $(\mathrm{Cl})$ of predicted $S / N$ value for the optimum factor level combination at $95 \%$ confidence band is calculated to determine whether the results of the confirmation experiments are reasonable or not. The $\mathrm{Cl}$ is calculated by Eq. 5 :

$$
C l=\sqrt{F_{\alpha ; 1, D F_{M S e}} \cdot M S e \cdot\left(\frac{1+m}{N}+\frac{1}{n_{r}}\right)}
$$

In Eq. $4, F_{\alpha}$ is the value of $F$ table, $\alpha$ - the error level, $D F_{M S e}$ - the degree of freedom of mean square error, $m$ - the degrees of freedom of $j$ factors, $N$ - the number of the total experiments and $n_{r}$ - the number of repetitions in the confirmation experiments. For the present study, $\mathrm{Cl}$ was found \pm 0.42 and this means that the experimental $S / N$ ratio for optimum conditions is located in the confidence interval, as shown Eq. 6. Therefore, the optimal air permeability can be obtained under the above-mentioned coating conditions.

RESULTS OF THE CONFIRMATION EXPERIMENT FOR AIR PERMEABILITY

\begin{tabular}{|c|c|c|c|} 
& \multirow{2}{*}{$\begin{array}{c}\text { Starting } \\
\text { coating } \\
\text { parameters }\end{array}$} & \multicolumn{2}{|c|}{ Optimal coating parameters } \\
\cline { 3 - 4 } & Prediction & Experiment \\
\hline Optimal level & A1B1C1D1E1 & A1B1C1D1E3 & A1B1C1D1E3 \\
\hline Air permeability & 45.18 & 46.07 & 49.12 \\
\hline S/N ratio & 33.05 & 33.39 & 33.79 \\
\hline
\end{tabular}

Predicted optimum $\mathrm{S} / \mathrm{N}-\mathrm{Cl}<$ Experimental optimum $S / N<$ Predicted optimum $S / N+C l$

$$
\begin{aligned}
33.39-0.42 & <33.79<33.39+0.42 \\
32.97 & <33.79<33.81
\end{aligned}
$$

Finally, first trial (A1B1C1D1E1) is selected as the initial design $(S / N=33.05 \mathrm{~dB})$, and the difference $(d)$, is obtained between the $S / N$ ratio of the predicted optimal design $(S / N)_{0}$ and the $S / N$ ratio of the selected design $(S / N)_{i}$ as shown below:

$$
\begin{gathered}
d=(S / N)_{0}-(S / N)_{i} \\
d=-10 \log L_{0}-\left(-10 \log L_{i}\right) \\
d=33.39-33.05=0.34 \mathrm{~dB}
\end{gathered}
$$

Improving rate obtained from using optimum factor levels, is achieved by the following equation (8):

$$
\begin{gathered}
L_{i} / L_{o}=10^{d / 10} \\
L_{i} / L_{o}=10^{0.34 / 10}=1.08 \text { times }
\end{gathered}
$$

According to this result, the air permeability of coated denim fabrics under optimum conditions is found to be improved 1.08 times.

\section{CONCLUSIONS}

In this study, the optimum coating conditions was determined for the air permeability of denim fabrics by Taguchi method. An optimum coating parameter combination for the maximum air permeability was obtained by using the analysis of signal-to-noise $(S / N)$ ratio. Based on the $S / N$ ratio, the optimum levels of the coating parameters for air permeability are 14 picks/cm weft density, $140^{\circ} \mathrm{C}$ drying temperature, 30 dpas viscosity, 3 bar squeeze pressure, $30 \mathrm{~m} / \mathrm{min}$ fabric passing speed. This combination was included in the test plan as Experiment No. 3. The level of importance of the process's parameters is determined by using ANOVA. As a result of ANOVA test, it was determined that air permeability can be improved significantly with weft density and viscosity for coated denim fabrics. The contribution ratios of weft density and viscosity are $96.6 \%$ and $0.79 \%$ on air permeability, respectively. This means that air permeability can be largely improved by the controlled change of weft density. In addition, a confirmation test was performed to see the improvement in the air permeability of the fabrics. The improvement of air permeability from the initial coating parameters to the 
predicted optimal coating parameters was found about 1.08 times. Moreover, it is seen that Taguchi method is a promising approach for optimizing coat- ing process parameters of denim fabrics to meet maximum air permeability, with a very limited number of experiments and short time.

\section{BIBLIOGRAPHY}

[1] Paul, R. Denim manufacture, finishing and applications, In: Woodhead Publishing Series in Textiles, Number 164, Elsevier, 2015, pp. 1-599.

[2] Sen, A. K. Coated textiles principles and applications, In: Copyright 2008 by Taylor and Francis Group, LLC, International Standard Book Number-13: 978-1-4200-5345-6, 2008, pp. 1-230.

[3] Smith, W. C. Smart textile coatings and laminates, In: Woodhead Publishing Series in Textiles: Number 90, The Textile Institute and Woodhead Publishing Limited, CRC Press LLC, 2010, pp. 1-304.

[4] Giessmann, A. Coating substrates and textiles, In: A Practical Guide to Coating and Laminating Technologies, Coatema Coating Machinery GmbH, Dormagen, Germany, 2012, pp. 1-243.

[5] Ogulata, R. T., Mezarcioz, S. M. Optimization of air permeability of knitted fabrics with the Taguchi approach, In: The Journal of The Textile Institute, 2011, Vol. 102, No. 5, pp. 395-404.

[6] Gunes, S., Manay, E., Senyigit, E. and Ozceyhan, V. A Taguchi approach for optimization of design parameters in a tube with coiled wire inserts, In: Applied Thermal Engineering, 2011, 31, pp. 2568-2577.

[7] Lai, H., Chang, Y. and Chang H., A robust design approach for enhancing the feeling quality of a product: a car profile case study, In: International Journal of Industrial Ergonomics, 2004, Volume 35, Issue 5, pp. 445-460.

[8] Jung, J. J., Kim, S., Park, C. K. Optimization of digital textile printing process using Taguchi method, In: Journal of Engineered Fibers and Fabrics, 2016, Volume 11, Issue 2, pp. 51-59.

[9] Maqsood, M., Hussain, T., Ahmad, N., and Hawab Y. Multi-response optimization of mechanical and comfort properties of bi-stretch woven fabrics using grey relational analysis in Taguchi method, In: The Journal of The Textile Institute, 2017, 108:5, pp. 794-802.

[10] Nassif, G.A. Using Taguchi methodology to optimize woven fabrics air permeability, In: Journal of Textile Science \& Engineering, 2017, Volume 7, Issue 6, pp. 2-4.

[11] Ahmad, N., Kamal, S., Raza, Z. A., Hussain, T., Anwar, F. Multi-response optimization in the development of oleohydrophobic cotton fabric using Taguchi based grey relational analysis, In: Applied Surface Science, 2016, 367, pp. 370-381.

[12] Mavruz, S., Ogulata, R.T. Taguchi approach for the optimisation of the bursting strength of knitted fabrics, In: Fibres \& Textiles in Eastern Europe 2010, Vol. 18, No. 2 (79) pp. 78-83.

[13] Shabaridharan K., Das, A. Analysis of thermal properties of multilayered fabrics by full factorial and Taguchi method, In: The Journal of The Textile Institute, 2014, Vol. 105, No. 1, pp. 29-41.

[14] Pundir, R., Chary, G.H.V.C., Dastidar, M.G. Application of Taguchi method for optimizing the process parameters for there moval of copper and nickel by growing Aspergillus sp., In: Water Resources and Industry, 2016, http://dx.doi.org/10.1016/j.wri.2016.05.001.

[15] Yang, W. H., Tarng, Y. S. Design optimization of cutting parameters for turning operations based on the Taguchi method, In: Journal of Materials Processing Technology, 1998, 84, pp. 122-129.

[16] Babayiğit, B., Şenyiğit, E. Design optimization of circular antenna arrays using Taguchi method, In: Neural Computing \& Applications, 2017, vol. 28, pp.1443-1452.

[17] Babayiğit, B., Şenyiğit, E., Mumcu, G. Optimum broadband E-patch antenna design with Taguchi method, In: Journal of Electromagnetıc Waves And Applications, 2016, vol. 30, pp. 915-927.

[18] Şenyiğit, E., Aydın, M.E., Düğenci, M., Zeydan, M. Heuristic-based neural networks for stochastic dynamic lot sizing problem, In: Applied Soft Computing, 2013, vol. 13, no. 3, pp. 1332-1339.

[19] Yildiz, Y.Ş., Şenyiğit, E., İrdemez, Ş. Optimization of specific energy consumption for Bomaplex Red Cr-L dye removal from aqueous solution by electrocoagulation using Taguchi-neural method, In: Neural Computing \& Applications, 2013, vol. 23, no. 3-4, pp. 1061-1069.

[20] Khosla, A., Kumar, S., Aggarwalk, K. K. Identification of strategy parameters for particle swarm optimizer through Taguchi method, In: J Zhejiang Univ SCIENCE A, 2006, 7(12):1989-1994.

[21] Ionesi, S. D., Dumitraş, C., Fangueıro, R., Ursache, M., Cıobanu, L., Dulgherıu, I. Evaluation of impact behaviour of composite materials using Taguchi method, In: Industria Textila, 2014, vol. 65, nr. 3, pp. 153-157.

[22] Tosun, N., Cogun, C. and Tosun, G. A study on kerf and material removal rate in wire electrical discharge machining based on Taguchi method, In: Journal of Materials Processing Technology, 2015, 152, pp. 316-322.

\section{Authors:}

\section{SÜMEYYE ÜSTÜNTAĞ HÜSEYIN GAZI TÜRKSOY}

Department of Textile Engineering, Erciyes University, 38039, Kayseri, Turkey e-mail: sumeyyeustuntag@erciyes.edu.tr; hgazi@erciyes.edu.tr

Corresponding author:

\section{SÜMEYYE ÜSTÜNTAĞ}

sumeyyeustuntag@erciyes.edu.tr 


\title{
Unravelling the effects of interorganizational networks on innovation in the textile industry. The case of the Valencian cluster in Spain
}

\author{
DOI: 10.35530/IT.070.03.1575
}

\section{REZUMAT - ABSTRACT}

Studiu privind efectele rețelelor interorganizaționale asupra inovării din industria textilă. Cazul unui cluster din Valencia, Spania

Cercetătorii au susținut ideea că rețelele interorganizaționale prin care se transmit fluxurile de cunoștințe în cadrul unui cluster reprezintă un factor-cheie al inovării pentru firmele din cluster. Cu toate acestea, dovezile empirice existente sugerează că, în timp ce aceste rețele pot spori performanța inovatoare a firmelor, nu toate legăturile create în cadrul rețelei influențează în aceeași măsură. Plecând de la acestă premisă, lucrarea urmărește să exploreze modul în care implicarea firmelor în retelele de afaceri și în cele de cunoștinte tehnice influentează inovarea în cadrul unui cluster textil spaniol. Rezultatele relevă o influență pozitivă asupra rezultatelor inovative exercitate doar de legăturile create între firmele care fac shimburi de cunoștințe tehnice în cadrul clusterului. Aceste constatări oferă informații relevante în scopul realizării unui management eficient al rețelelor teritoriale la nivelul firmelor și pentru o mai bună definire a politicilor industriale adoptate în cadrul clusterelor textile.

Cuvinte-cheie: rețea de cunoștințe în afaceri, clustere, inovare, relații interorganizaționale, rețea de cunoștințe tehnice, industria textilă

\section{Unravelling the effects of interorganizational networks on innovation in the textile industry.} The case of the Valencian cluster in Spain

Scholars have supported the idea that interorganizational knowledge networks are a key factor for firms' innovation in clusters. Yet, existing empirical evidence suggests that, while networks can enhance firms' innovative performance, not all network linkages influence to the same extent. On this basis, this paper aims to explore in a Spanish textile cluster how the involvement in business and technical knowledge networks influences textile firms' innovation. The results reveal the influence of the firms' connectedness to the cluster knowledge network on their innovative results, although only in the case of the technical knowledge network. These findings provide relevant insights for an efficient management of territorial networks at the firm level and for a better definition of textile clusters' industrial policies.

Keywords: business knowledge network, clusters, innovation, interorganizational relationships, technical knowledge network, textile industry

\section{INTRODUCTION}

Over the last decades, the textile industry has developed a broad process of globalization that has led its firms to develop a robust network of international relations and extend their processes around the world [1]. Despite this scenario, the importance of local relations in localised textile clusters has not lost value, allowing their companies to improve their knowledge bases and innovation capabilities [2]. The effective management of this knowledge intensive "global context" [3] can help textile firms to improve their competitiveness and adapt to future challenges. The importance of collaborative knowledge networks in regional clusters has been highlighted by numerous research contributions [4-5]. These studies emphasized the importance of the territory, which through its collaborative and localized networks, influenced firms' innovative behaviour and performance. For example, Signorini [6] in the Italian textile industrial clusters of Prato and Biella revealed the existence of productivity and profit differentials in favour of firms belonging to these clusters compared to non-cluster firms. However, in recent years, literature has questioned this view, carrying out a "relational turn" [7] and focusing more on established linkages and networks than on geography per se [8]. This change implies a focus on the firm itself and its set of relationships rather than on the territory, highlighting that it is these actors and elements that make it possible to generate their regional environments [9].

This relational turn has generated an important debate in economic geography, helping to overcome the limitations of previous research work. Among the most relevant questions addressed and still being unravelled, we may find those related to the way in which the nature of networks impacts on the economic development of regional clusters [8]. In general, scholars have supported the idea that interorganizational networks are a key factor for firms' innovation in clusters [10-12]. However, existing empirical 
evidence suggests that although networks can enhance innovation processes, not all network ties or structures do so equally [13-14]. In this sense, the involvement of firms in the cluster business and technical knowledge networks may have a different influence on their performance. In addition, the specific characteristics of certain industrial sectors may determine the presence of such networks and their influence on the firms' innovation performance.

The textile industry has undergone a remarkable process of modernization in recent years through the acquisition of new knowledge to face the new challenges of the global competitive scenario. Thus, textile firms, especially those in the more advanced economies, have increased the development of innovative products in new market niches thanks in part to the development of an appropriate portfolio of knowledge relationships.

Challenged by the above theoretical premises and the absence in the literature of unambiguous evidence on the impact of networks on innovation, this paper aims to explore in textile industrial clusters how the involvement in business and technical knowledge networks influences the innovation performance of textile firms. To address this research question, the empirical study draws on a sample of 92 firms belonging to the textile industrial cluster of Valencia, located in one of the most important industrial areas in the eastern Spain.

This paper is structured as follows: first, theoretical foundations upon which the research is based are discussed. Research hypotheses are defined within this section. Next, the research design and the results of the empirical study are described. Lastly, main conclusions are presented along with the limitations of the work.

\section{THEORETHICAL FRAMEWORK AND RESEARCH HYPOTHESES}

In the new globalised environment, textile companies are under enormous pressure from the competitive context and fashion retailers and distributors, questioning their capacity to survive and carry out their activities efficiently [15]. While some textile companies in cluster have relied on strategies focusing on relocating activities to low-cost countries and reducing prices, more resilient companies have promoted functional and inter-sectoral improvement strategies [16]. In this sense, these textile companies have taken on new, higher value-added functions in their activities, such as R\&D, design or marketing. In addition, they have also sought synergies with other sectors by expanding their product range, for example through the development of new technical textiles for the car, construction or health industries, among others.

Textile firms' worldwide competitiveness increasingly tends to be grounded on a unique collection of assets and capabilities developed by each company over time through internal resources and also external sources, especially those closely related to the cluster.
Thus, thanks to their frequent grouping in clusters, textile firms can access new external sources of knowledge and upgrade their knowledge base and competitive advantage through multiple collaborative networks [17].

Numerous contributions have pointed out the presence in clusters of a multiple set of overlapping networks [8, 18]. In particular, the literature emphasizes the existence mainly of a business knowledge network (BKN) and a technical knowledge network (TKN).

According to Giuliani, the BKN can be defined as the set of relationships established by cluster firms when they interact on issues related to their business [8]. Business knowledge networks appear in cluster contexts thanks to the frequent occurrence of market, social and institutional relationships [11]. The trade in raw or semi-processed materials, membership of the same local associations or the attendance at social events in the local context are examples of these types of relationships.

On the other hand, the TKN deals more with technical knowledge as well as the resolution of problems within the firm. More concretely, the TKN is defined as the informal and unplanned network that links firms through the knowledge transfer, aimed at the solution of complex technical problems promoted by the local community of technicians and entrepreneurs [8].

The BKN structurally differs from the TKN [11]. While the $\mathrm{BKN}$ is extensive, allowing a large number of cluster firms to be linked together, the TKN is selective because it sties are unevenly distributed [8]. Therefore, the BKN is expected to be denser than TKN.

The literature agrees with the positive influence of cluster networks on innovation [19-20]. Yet, as suggested by different authors, not all network linkages have the same influence [13-14]. The type of network determines the kind of knowledge acquired. Thus, the knowledge acquired in the BKN differs from that obtained in the TKN.

On the other hand, knowledge of the cluster is not obtained in a homogeneous way among its companies, thus contributing to the divergent innovative results of cluster firms. Among the main characteristics of cluster networks and firms that determine their capability to innovate is the level of network connectedness. This is defined as the number of ties that a company maintains in the cluster, allowing it to represent the opportunities it has to obtain new knowledge. The literature shows a positive effect of cluster network connectedness on firm innovation [21].

Therefore, from a multi-network approach in clusters, we expect that the connectedness of cluster firms to both their BKN and TKN will provide their companies with new knowledge and skills in different areas that will lead them to improve their innovative performance. In this way, a high level of connectedness to the BKN is expected to provide firms with new general information on the business or industry, better 
access to international markets, institutional information or new commercial exchanges that may have an impact on the improvement of their strategies. On the other hand, we expect that those companies that are better connected to the TKN will have a better chance of solving technical problems and generating new ideas to improve processes and products both in the current market and in new market niches. In consequence and based on the previous theoretical framework, we can formulate the following two hypotheses:

H1: The level of connectedness of a textile firm in the cluster BKN positively influences its innovative performance.

H2: The level of connectedness of a textile firm in the cluster TKN positively influences its innovative performance.

\section{EMPIRICAL SETTING}

\section{The Valencian textile cluster}

The textile industry in Spain has traditionally played a central role in its pattern of industrial specialization. Among the most important textile areas in this country, we find the Valencian textile cluster, where a wide range of SMEs carry out a wide variety of activities, from spinning to dyeing, printing or weaving. This cluster, which is located in eastern Spain, comprises numerous textile SMEs, employing 22,695 workers with a production value about 1,975 million Euros in 2016 according to the Spanish Inter-Textile Council (CITYC). In addition, it accounts for the 19 percent of the total Spanish sector.

Traditionally, the Valencian textile cluster has distinguished itself in recent decades by the production and commercialization of home-textiles in the form of a wide range of traditional products among which we can highlight blankets, duvets, upholstery and curtains. However, the economic crisis at the end of the last decade has forced these companies to look for new sectors and reposition their products in high added value segments. Among these actions, we highlight the development of new yarns and nonwoven and woven fabrics of a more technical profile for new sectors and industries. This fact has enabled many Valencian firms, either to devote part of their production or, in other more extreme cases, their totality, to high added value technical textiles mainly intended for the technical clothing and footwear, automotive and transport and healthcare industries. This evolution of the companies has allowed the cluster to grow again and partly regain the momentum that it had decades ago. This fact is corroborated by the data provided by CITYC. According to this institution, the Valencian textile cluster has experienced an increase of about $13 \%$ in turnover and of about $20 \%$ in exports over the period 2012-2016.

\section{Sample collection and data sources}

The data collection process started with the definition of the study population. To proceed, firstly, we drew up a roster of companies from the $\mathrm{SABI}^{1}$ database including general information about firms in the textile cluster, such as their location, main activities, turnover, financial performance and number of employees. As we commented earlier, the textile cluster in Valencia is made up of a wide range of manufacturing processes involving a large number of primary and auxiliary activities. Thus, the number of companies in the cluster is large, around 300, mainly including micro enterprises and SMEs. Such a large number of companies cannot, however, be managed in the roster-recall technique used to obtain reticular data. So, in order to refine the population, from the initial list we selected the companies that are more representative, based on the opinion of a panel of experts from several cluster institutions (such as the Universitat Politècnica de València and the main trade associations) and following criteria such as turnover, number of employees or commercialization of innovative products. After applying this filter, a final sample of 110 companies was established, thereby allowing us to proceed with a representative set of enterprises from the total population addressed by this research.

Data collection took place between July and September 2016. To collect network data, we applied the roster-recall method [22], since it has been frequently used in previous research in this particular field [18, 23]. This technique consists in sending a questionnaire to a sample of firms, attaching the complete list of these firms. They are then invited to select from an open list of local companies those from which business and/or technical knowledge was received. Additionally, participants are also invited to include the firms not on the list from which business and/or technical advice was obtained.

Complementarily, firms were also asked to provide information about their market strategies, innovation activities and product portfolio. The process concluded satisfactorily with a total of 92 completed questionnaires obtained. Network data were recorded in two 92 by 92 data matrices in which cell ij was coded ' 1 ' when any of the respondents of firm $i$ reported technical or business tie with firm $j$.

In order to improve the understanding of the sample studied, table 1 shows a classification of the analysed companies according to their activity, size and age.

Finally, in order to statistically validate that the sample is representative from the entire Valencian textile cluster, we performed a Student's t-test. To proceed, we carried out three different tests referring to the variables number of employees, turnover and age. We used SABI database as the source of this information. The results confirmed the representativeness of the sample used for the research as we cannot reject the null hypothesis about mean differences,

\footnotetext{
$1 \mathrm{SABI}$ is a directory of Spanish and Portuguese companies that collects general information and financial data. In the case of Spain, it covers more than 95 percent of the companies of the 17 Spanish regions with total yearly revenues over $360,000-420,000 €$.
} 


\begin{tabular}{|c|c|c|}
\hline Characteristics of firms & Number & Percentage \\
\hline \multicolumn{3}{|l|}{ Number of employees } \\
\hline small (1-20) & 43 & $46.74 \%$ \\
\hline medium $(21-100)$ & 42 & $45.65 \%$ \\
\hline large $(>100)$ & 7 & $7.61 \%$ \\
\hline \multicolumn{3}{|l|}{ Year of foundation } \\
\hline before 1966 & 10 & $10.87 \%$ \\
\hline $1966-1975$ & 11 & $11.96 \%$ \\
\hline $1976-1985$ & 26 & $28.26 \%$ \\
\hline 1986-1995 & 29 & $31.52 \%$ \\
\hline 1996-2005 & 13 & $14.13 \%$ \\
\hline 2006 to today & 3 & $3.26 \%$ \\
\hline \multicolumn{3}{|l|}{ Activity } \\
\hline Yarn manufacturing & 15 & $16.30 \%$ \\
\hline Fabric manufacturing & 41 & $44.57 \%$ \\
\hline Non-woven manufacturing & 9 & $9.78 \%$ \\
\hline $\begin{array}{l}\text { Textile finishing, dyeing and } \\
\text { printing }\end{array}$ & 27 & $29.35 \%$ \\
\hline
\end{tabular}

number of employees $(t=-.204$; sig $=.839)$, turnover $(t=-.609 ; \mathrm{sig}=.544)$ and age $(t=1.637 ; \mathrm{sig}=.105)$.

We can consequently conclude that there is no bias between sample and population.

\section{Variables}

\section{Innovation}

This variable attempts to capture the capacity of the company to improve processes in the existing products and services. We have measured this variable by adapting the scale of Jansen et al. of the variable incremental innovation to the particular characteristics of our study [24]. We have used incremental innovation variable as a general innovation measure of cluster firms because this type of innovation, as opposed to radical innovation, is the most representative in cluster contexts of medium-low tech industries such as textiles and also where there is a prevalence of SMEs [25]. We used a seven-point Likert scale with seven different items. The items were defined as follows: 1) your company frequently improves the existing range of products and services; 2) your firm regularly applies small adaptations to the existing products and services; 3 ) improvements in existing products and services are introduced in the local market by your company; 4) your firm improves the efficiency of your supplies of products and services; 5) your company increases economies of scale in existing markets; 6) your firm provides services to the existing customers; and finally 7) reducing costs of internal business processes is a major goal in your company. A factor analysis was run to identify the multi-item scale of the innovation construct. The resulting Cronbach's alpha value was 0.905 and the results of the factor analysis reported by the Barlett's test of sphericity were significant $\left(\chi^{2}=324.834\right.$; $p<.001)$. On the other hand, the value of the KaiserMeyer-Olkin (KMO) measure of adequacy was greater than $0.6(\mathrm{KMO}=.892)$. Therefore, the data

collected in this measure were adequate for factor analysis. Finally, the analysis revealed a one-factor solution representing $62 \%$ of the overall variance.

\section{Firm connectedness}

This variable seeks to capture the level of connectedness of the cluster firms within the cluster boundaries for both, BKN and TKN. In line with Boschma and TerWal [26], we followed an ego-network approach, estimating the firm connectedness to each network by means of the size of the egonet of each node in both networks. An egonet or ego-network is a part of the whole cluster's network that consists of a firm (ego), all its relations to other firms (alters) and the relationships among them. The larger the size of a firm's egonet, the larger its connectedness to the network. From the knowledge relationship data matrices previously obtained from the roster-recall method, we calculated each firm's egonet in both networks through social network analysis techniques using the UCINET v.6 software application [27]. These techniques provide a tool to explore the structural properties of a network, and encompass theories, models and applications that are expressed in terms of relational concepts or processes [22]. They have been used in cluster studies by several authors $[11,18,26]$.

\section{Statistical methods}

As commented earlier, network data gathered in the roster-recall method were processed using UCINET v6 software [27]. Complementarily, ANOVA Independent simple t-test was performed to analyse the influence of cluster interorganizational knowledge networks on innovation by means of inter-group comparisons. To proceed, we previously confirmed two basic assumptions. First, it was verified that data were normally distributed (Shapiro-Wilk test at $p>.05$ ). In addition, it was also confirmed that there was homogeneity of variances between the groups analysed (Levene test at $p>.05)$. For all these analyses, we used the SPSS v16 statistics software.

\section{RESULTS}

Before addressing research hypotheses, the basic descriptive statistics of the cluster BKN and TKN (table 2) calculated through Social Network analysis are presented.

Based on the figures from the table above, we can see that both networks show notable levels of interaction,

\begin{tabular}{|l|c|c|}
\hline \multicolumn{1}{|c|}{ Indicators } & BKN & TKN \\
\hline Number of nodes in the network & 92 & 92 \\
\hline Density & $4.1 \%$ & $2.3 \%$ \\
\hline Number of ties in the network & 346 & 190 \\
\hline $\begin{array}{l}\text { Average connectedness (average } \\
\text { number of ties per node) }\end{array}$ & 3.761 & 2.065 \\
\hline Isolated nodes & 17 & 24 \\
\hline Gini Coefficient & 0.601 & 0.752 \\
\hline
\end{tabular}


thus confirming that the textile firms significantly develop both business and technical knowledge relationships. On the other hand, they also confirm that density, that is, the proportion of linkages in the network compared to the total possible linkages, is significantly higher in the BKN (4.1\%) than in the TKN $(2.3 \%)$. This leads us to deduce that the textile firms in the sample have more business than technical knowledge relationships. In addition, the higher presence of business knowledge relationships is also confirmed by the number of links in the networks and the average number of ties per node, which are considerably higher in the BKN. Thus, we can conclude that the textile cluster TKN is more restrictive than the $\mathrm{BKN}$, as already suggested by previous empirical studies. On the other hand, the Gini concentration index measures the degree of inequality in the distribution of links between the textile firms. As this index approaches one, the number of linkages established by the actors of a network is much more unequal. Conversely, a value close to zero indicates a more homogeneous distribution of the links between the different actors of the network. In the Valencian textile cluster, both networks analysed show high levels of heterogeneity in the number of relationships per firm, although significantly higher for the TKN. In this way, the access of the textile firms to the TKN is done more unevenly than the access they perform to the $\mathrm{BKN}$. This fact is also corroborated by the number of isolated companies, which is notably higher in the TKN than in the BKN.

Complementarily, the graphical representation of both networks (figures 1 and 2) allow verifying the results obtained from the descriptive statistics. In the figures, one node represents one textile firm, and a line between two nodes indicates the presence of a relation between them. The direction of the line indicates how knowledge flows between the two companies. As can be visually verified, the BKN has a higher density.

Once the main differences between the textile cluster BKN and TKN were identified, we analysed to what extent the involvement of textile firms in these networks influence firm's innovation (hypotheses 1 and 2). To this end, we studied the relation between the firms' connectedness to these networks and their innovative performance.
To proceed, we initially divided the firms in each network according to their level of connectedness. More precisely, we calculated each firm's connectedness values for the BKN and TKN and then, classified them into three groups in both networks according to this value. Thus, the first group (G1) is made up of the nodes with a low connectedness value (lower tercile), that is, the firms less connected to the network. A second group (G2) made up of the nodes with intermediate connectedness values (central tercile), was composed of the firms located in a medium relational position, and finally, the third group (G3) which brings together the firms with a high connectedness value (higher tercile). As a result, three groups were obtained for each network (BKN and TKN) of similar size. Specifically, Group 1 and Group 2 comprised 31 firms each one and Group 330 . Once the firms were classified into three groups for both networks according to their relational level, we proceeded to analyse the differences between the innovative performance of the firms in each of the three groups separately for both BKN and TKN.

As we indicated above, since assumptions of normality and homoscedasticity were met for all cases, we considered the application of ANOVA Independent simple t-test. In this case, the design of the experiment for both networks would have two independents factors (high, medium or low connectedness in the BKN and high, medium or low connectedness in the TKN), while firm's innovation performance would be taken as the dependent variable. The results of the ANOVA tests are shown in table 3.

Based on previous results, we only found significant differences in the mean innovative performance among the different groups in the case of the TKN. Therefore, hypothesis 2 cannot be supported by the empirical evidence.

In order to assess where the differences among the three groups in the TKN are, we performed a posthoc analysis through pair-wise comparisons. In this case, we used the Tukey method, an analysis commonly accepted in research. The results are shown in table 4.

The results point out that the mean of the innovative performance of the group of firms with higher connectedness (G3) in the TKN is higher than and significantly different to the others ( $G 1$ and $G 2$ ). Thus, this third group would comprise a homogeneous

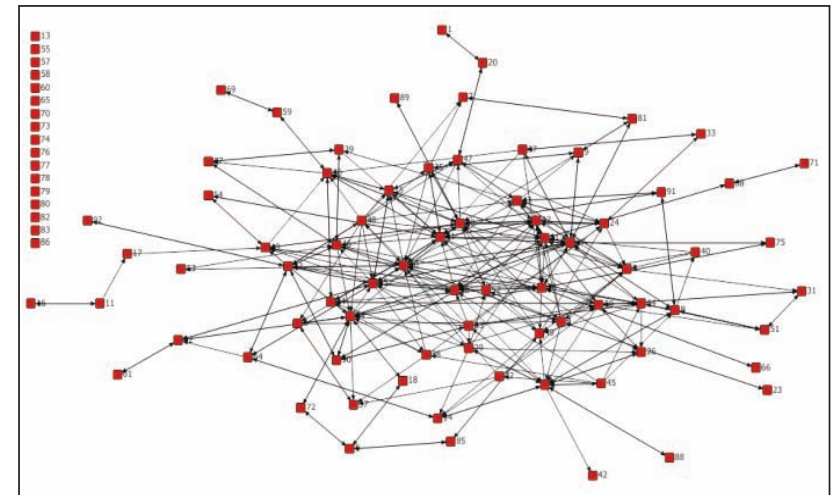

Fig. 1. Graphical representation of the BKN

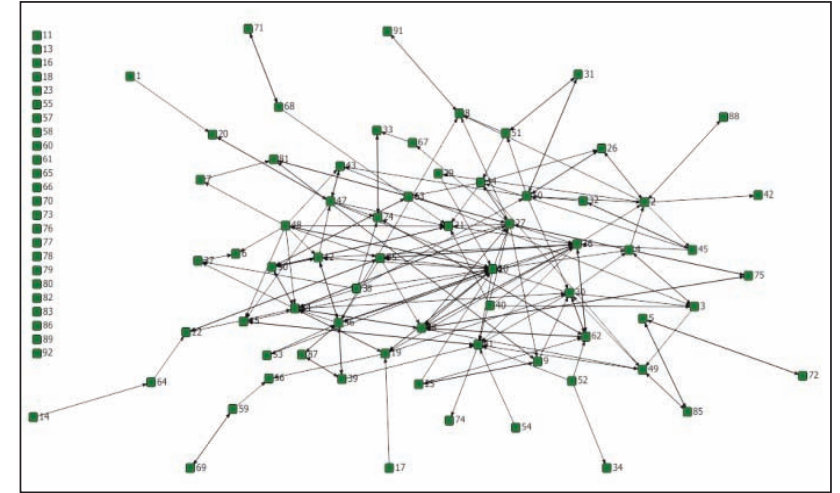

Fig. 2. Graphical representation of the TKN 


\begin{tabular}{|c|c|c|c|c|c|c|c|c|c|}
\hline Network & G1 Mean & G1 Sd. & G2 Mean & G2 Sd. & G3 Mean & G3 Sd. & df & F & Sig \\
\hline BKN & .083 & .988 & .135 & 1.026 & .163 & .771 & 2 & .057 & .945 \\
\hline TKN & -.410 & .966 & .102 & .814 & .705 & .628 & 2 & 14.251 & $.000^{* *}$ \\
\hline
\end{tabular}

Note: ${ }^{*} p<.05 ;{ }^{*} p<.01$

Table 3

\begin{tabular}{|c|c|c|c|c|c|c|c|c|}
\hline \multicolumn{3}{|c|}{ G1-G2 } & \multicolumn{3}{|c|}{ G1-G3 } & \multicolumn{3}{|c|}{ G2-G3 } \\
\hline Dif. & Std. error & Sig. & Dif. & Std. error & Sig. & Dif. & Std. error & Sig. \\
\hline-.512 & .207 & $.040^{*}$ & -1.115 & .209 & $.000^{* *}$ & -.603 & .209 & $.013^{*}$ \\
\hline
\end{tabular}

Note: ${ }^{*} p<.05 ;{ }^{* *} p<.01$

group. In turn, the mean of the innovative performance of the firms of the second group is also higher and significantly different than those of the first group. Therefore, G1 and G2 would also comprise two others homogeneous groups. Based on these results, we can assume hypothesis 1 . With the goal of clarifying this finding, we included the bar diagrams per group (figure 3 ) in the TKN.

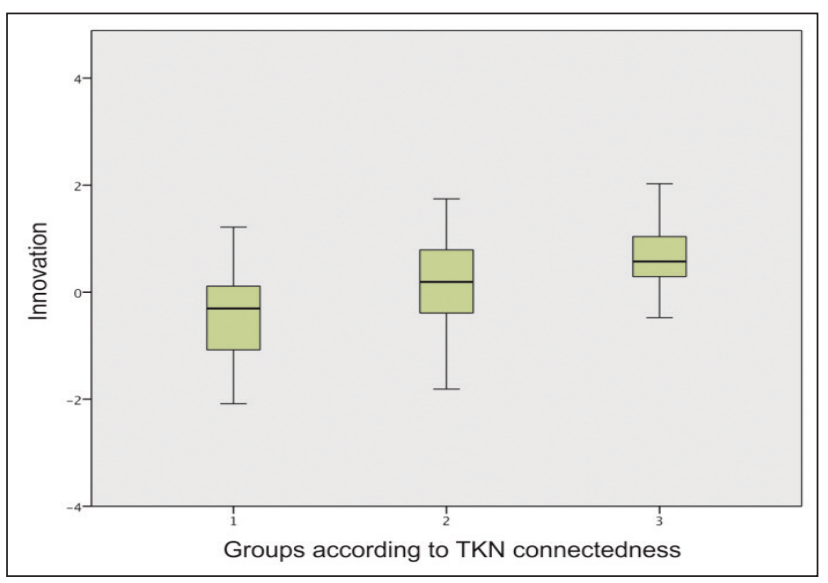

Fig. 3. Box-plot of the results

\section{CONCLUSIONS}

The aim of this work has been to study the structure of collaborative networks in a textile cluster and their influence on firms' innovative performance. The results obtained confirm the notable presence of both business and technical knowledge relationships in the textile cluster studied. They also confirm, as it was stated in the theoretical development, the unequal distribution of relations in these networks, both at a general level between the two networks and specifically between the companies in each of them. Furthermore, the results reveal the influence of the firms' connectedness to the cluster network on their innovative results, although only in the case of the TKN.

These results show the relevance of technical knowledge links in the innovation processes of textile companies, as is the case in other industrial sectors such as the wine industry [11, 18] or toy industry [28]. Conversely, the business knowledge linkages in the textile cluster do not have a significant influence on the innovative performance of their firms, which demonstrates that in these linkages, the type of knowledge acquired is not relevant to the innovation processes of textile companies, especially those more closely linked to product innovation, which is the type of innovation addressed in this research. This may be due, as suggested by Malmberg [29], to the fact that local business relations 'are relatively broad and diffuse, sometimes unwanted and often seemingly of little immediate use'. On the contrary, relationships within the TKN are more profound and directed towards solving specific problems, many of which usually deal with technical aspects of textile products and processes. These findings not only enhance the academic corpus of the cluster and textile literature, but also provide insights for an efficient management of territorial networks at the firm level and for a better definition of clusters' industrial policies. In this sense, managers, local institutions and policymakers must be aware of the advantages provided by the exchange of technical knowledge between cluster firms to improve their innovative performance. On the other hand, they should promote the development of joint actions and research projects within the cluster that facilitate the exchange of know-how and experience between companies.

Finally, this research suffers from some limitations. In this way, the stage of the cluster life cycle, the current post-crisis situation or the types of textile products produced by the companies studied may affect the potential generalization of the results in other textile clusters. Therefore, we must be cautious about the universality of these results and a broader analysis is in consequence needed to study how other cases vary. On the other hand, the conceptual division between BKN and TKN can be somehow considered as partially blurred, which makes it difficult to compare and draw conclusions. However, the operationalization of concepts that are to some extent complex and abstract into measurable variables, necessarily requires for simplification. Finally, while BKN connectedness does not influence product innovation, we can expect that it may influence other types of innovation such as market innovation. However, we leave this analysis for future work. 
[1] Guerrieri, P., Pietrobelli, C. Industrial districts' evolution and technological regimes: Italy and Taiwan. In: Technovation, 2004, vol. 24, no. 11, pp. 899-914.

[2] Expósito-Langa, M., Molina-Morales, F.X., Tomás-Miquel, J.V. How shared vision moderates the effects of absorptive capacity and networking on clustered firms' innovation. In: Scandinavian Journal of Management, 2015, vol. 31, no. 3, pp. 293-302.

[3] Onsager, K., Isaksen, A., Fraas, M., Johnstad, T. Technology cities in Norway: Innovating in glocal networks. In: European Planning Studies, 2007, vol. 15, no. 4, pp. 549-566.

[4] Piore, M.J., Sabel, C.F. The second industrial divide: possibility for prosperity, New York, Basic Books, 1984.

[5] Camagni, R. Innovation networks: spatial perspectives, London, New York, Belhaven Press, 1991.

[6] Signorini, L.F. The price of Prato, or measuring the industrial district effect. In: Papers in Regional Science, 1994, vol. 73, no. 4, pp. 369-392.

[7] Boggs, J.S., Rantisi, N.M. The 'relational turn' in economic geography. In: Journal of economic geography, 2003, vol. 3, no. 2, pp. 109-116.

[8] Giuliani, E. Clusters, networks and economic development: an evolutionary economics perspective. The Handbook of Evolutionary Economic Geography, 2010, pp. 261-279.

[9] Bathelt, H., Glückler, J. Toward a relational economic geography. In: Journal of economic geography, 2003, vol. 3, no. 2, pp. 117-144.

[10] Bathelt, H., Malmberg, A., Maskell, P. Clusters and knowledge: local buzz, global pipelines and the process of knowledge creation. In: Progress in Human Geography, 2004, vol. 28, no. 1, pp. 31-56.

[11] Giuliani, E. The selective nature of knowledge networks in clusters: Evidence from the Wine Industry, In: Journal of Economic Geography, 2007, vol. 7, pp. 139-68.

[12] Expósito-Langa, M., Tomás-Miquel, J.V., Molina-Morales, F.X. Innovation in clusters: exploration capacity, networking intensity and external resources. In: Journal of Org. Change Management, 2015, vol. 28, no. 1, pp. $26-42$.

[13] Peng, M. W., Luo., Y. Managerial ties and firm performance in a transition economy: The nature of a micro-macro link. In: Academy of Management Journal, 2000, vol. 43, no. 3, pp. 486-501.

[14] Stam, W., Elfring. T. Entrepreneurial orientation and new venture performance: The Moderating role of intra- and extraindustry social capital, In: Academy of Management Journal, 2008, vol. 51, no. 1, pp. 97-111.

[15] Abernathy, F.H., Volpe, A., Weil, D. The future of the apparel and textile industries: prospects and choices for public and private actors. In: Environment \& Planning A, 2006, vol. 38, no. 12, pp. 2207-32.

[16] Humphrey, J., Schmitz, H. How does insertion in global value chains affect upgrading in industrial clusters?. In: Regional studies, 2002, vol. 36, no. 9, pp. 1017-1027.

[17] Dahl, M.S., Pedersen, C.Ø.R. Knowledge flows through informal contacts in industrial clusters: myth or reality?. In: Research Policy, 2004, vol. 33, pp. 1673-1686.

[18] Morrison, A., Rabellotti, R. Knowledge and information networks in an Italian wine cluster, In: European Planning Studies, 2009, vol. 17, pp. 983-1006.

[19] Coombs, J., Deeds, D., Ireland., R. Placing the choice between exploration and exploitation in context: A study of geography and new product development. In: Strategic Entrepreneurship Journal, 2009, vol. 3, no. 3, pp. 261-279.

[20] Schilling, M.A., Phelps, C.C. Interfirm collaboration networks: The impact of large-scale network structure on firm innovation. In: Management Science, 2007, vol. 53, no. 7, pp. 1113-1126.

[21] Bell, G.G. Clusters, networks, and firm innovativeness. In: Strategic Management Journal, 2005, vol. 26, no. 3, pp. $287-95$.

[22] Wasserman, S., Faust, K. Social network analysis. Methods and applications, Cambridge, Cambridge University Press, 1994.

[23] Giuliani, E., Bell, M. The Micro-determinants of meso-level learning and innovation: Evidence from a Chilean wine cluster, In: Research Policy, 2005, vol. 34, no. 1, pp. 47-68.

[24] Jansen, J.J., Van Den Bosch, F.A., Volberda, H.W. Exploratory innovation, exploitative innovation, and performance: Effects of organizational antecedents and environmental moderators, In: Management Science, 2006, vol. 52, no. 11, pp. $1661-1674$

[25] Forsman, H., Annala, U. Small enterprises as innovators: Shift from a low performer to a high performer, In: International Journal of Technology Management, 2011, vol. 56, no. 2/3/4, pp. 154-171.

[26] Boschma, R.A., TerWal, A.L.J. Knowledge networks and innovative performance in an industrial district: the case of a footwear district in the South of Italy, In: Industry \& Innovation, 2007, vol. 14, no. 2, pp. 77-199.

[27] Borgatti, S.P., Everett, M.G., Freeman, L.C. Ucinet for Windows: Software for Social Network Analysis, Analytic Technologies, Natick, MA, 2002.

[28] Morrison, A. The Dynamics of Technical and Business Networks in Industrial Clusters: Embeddedness, status or proximity? 35th DRUID Conference, 2013, Barcelona, Spain, June 17-19.

[29] Malmberg, A. Beyond the cluster - local milieus and global economic connections. In: Remaking the Global Economy, 2003, pp. 145-59.

\section{Authors:}

\section{JOSÉ-VICENTE TOMÁS-MIQUEL ${ }^{1}$, MANUEL EXPÓSITO-LANGA ${ }^{1}$, GABRIEL BRĂTUCU ${ }^{2}$, OANA BĂRBULESCU ${ }^{2}$}

${ }^{1}$ Universitat Politècnica de València, Business Administration Department, 03801, Alcoy, Spain

${ }^{2}$ Transilvania University of Brașov, Faculty of Economic Sciences and Business Administration, 500036, Brașov, Romania

e-mail: jotomi@doe.upv.es, maexlan@doe.upv.es, gabriel.bratucu@unitbv.ro, oana.barbulescu@unitbv.ro

\section{Corresponding author:}

OANA BĂRBULESCU

e-mail: oana.barbulescu@unitbv.ro 


\title{
Evaluating firms' financial performance in textile industry of Romania
}

\author{
DOI: $10.35530 / I T .070 .03 .1398$
}

\section{Evaluarea performanței financiare a firmelor din industria textilă din România}

Evaluarea performanței financiare a unei firme sau a unui sector este o problemă importantă pentru managerii, investitorii și partenerii de afaceri. Informațiile de bază utilizate pentru evaluarea performanței financiare se găsesc în situațiile financiare. Precizia metodei utilizate pentru această evaluare depinde de exactitatea situațiilor financiare furnizate de firme care reflectă activitatea desfășurată. În această lucrare propunem un indice agregat pentru evaluarea performanței financiare, pe baza a 11 rate financiare selectate. Metoda a fost aplicată pe un eșantion de 82 de întreprinderi mijlocii care activează în sectorul textil din România. Industria textilă este o industrie cu tradiție și un sector important al economiei românești, atât în ceea ce privește contribuția la produsul intern brut, cât și creșterea exporturilor; a suferit în ultimii 20 de ani o perioadă dificilă de transformare și adaptare la o piață în schimbare, dar are un avantaj competitiv raportat la cel european, în principal datorită forței de muncă cu costuri reduse. Rezultatele cercetării arată ierarhia firmelor din sectorul textil în funcție de scorul performanței financiare, 42,68\% dintre firme având un scor mai mare decât media sectorului. Rezultatele sunt utile, în special pentru manageri, prin îmbunătățirea procesului de luare a deciziilor privind finanțarea și dezvoltarea afacerilor, prognozarea viitoarei performanțe financiare, selectarea partenerilor de afaceri, realizarea de investiții profitabile, dar și pentru analiștii financiari în îndeplinirea obiectivelor de afaceri.

Cuvinte-cheie: informații contabile, luarea deciziilor; indice agregat, scorul ferm, întreprinderi mijlocii

\section{Evaluating firms' financial performance in textile industry of Romania}

Assessing the financial performance of a firm or sector is an important issue for managers, investors and business partners. The basic information used for financial performance assessment is found in financial statements. The accuracy of the method used for this evaluation depends on the accuracy of financial statements provided by firms that reflect the activity developed. In this paper we propose an aggregated index for evaluation the financial performance, based on 11 selected financial rates. The method was applied on a sample of 82 medium-sized companies acting in the Romanian textile sector. Textile industry is an industry with tradition and an important sector of Romanian economy, both in terms of the contribution to gross domestic product and export growth; it has undergone in the last 20 years a difficult period of transformation and adaptation to a changing market, but has a competitive advantage reported to the European one, mainly due to low-cost labour force. The research results show the hierarchy of the textile firms after financial performance score, $42.68 \%$ of firms having a score above sector average. The results are useful, especially to managers, by improving decision making of business funding and development, forecasting the future financial performance, selecting business partners, making profitable investments, and to financial analysts in fulfilment of business objectives.

Keywords: accounting information, decision making, aggregated index, firm score, medium-sized firms

\section{INTRODUCTION}

Financial performance assessment is currently an important topic among managers, shareholders, investors, creditors, financial analysts and also researchers. Numerous theoretical and practical articles present different ways to measure the financial performance, for many and diverse sectors, for example: iron and steel industry [1], manufacturing [2], agriculture [3], retail [4], hotels industry [5], transportation [3, 6], financial investments, banks [7-8], insurance companies [9].The necessity for managers, investors, business partners and financial analysts is that these methods must be more efficiently, easy to apply, and show the real financial performance in order to make decisions for increase the performance, develop activity or avoid bankruptcy, to make good and profitable investments, to choose solvent business partners and realize a hierarchy and comparative analysis of the firms acting in a sector, and/or a certain period. The evaluation of financial performance depends on the accuracy of accounting information.

The quality of accounting information can reduce a firm's exposure to systematic liquidity risk and can affect firm valuation and cost-of-capital through their impact on different aspects of liquidity, especially when some events (e.g. financial crisis) may arise. Thus is confirmed the important role of accounting information during liquidity events [10]. The use of proper accounting information and analytic techniques can help a tolerated union of necessity between revenue management programs and firm strategy [11] that can increase financial performance of firms. After analysing various studies performed by theorists in the field [12-13] we concluded that the accounting information in an enterprise foresees the critical decisions that influence the decision to facilitate information for management control as well. We 
note that the accounting information has, as a starting point, two different and uneven sources in terms of quality, that information coming as a result of transactions carried out on various markets being seen during the financial year, having a rigorous and objective character, and that information known at the end of the year that is largely the result of estimates and reflects the accounting policies of the enterprise management.

The usefulness of accounting information increases if it is comparable, verifiable, readily available and understandable. Relevance and faithful representation of the accounting information are considered fundamental qualitative characteristics because it is used for calculation of a wide range of indicators in financial analysis and diagnosis. The main users of accounting information issued in a firm are: current and potential investors, the firm management, employees, financial and trade creditors, customers, financial analysts, the government and its institutions, and the general public, each of them having specific interests.

Hall considers that managers primarily use accounting information to develop knowledge of their work environment rather than as an input into specific decision-making scenarios [14]. In this role, accounting information can help managers to develop knowledge to prepare for unknown future decisions and activities. We know that accounting information is just one part of the wider information set that managers using to decision making and the quality of decisions depend on other sources of information at a manager's disposal. Also, managers interact with information and other managers utilising and verbal forms of communication that is not based on written reports. For investors, accounting information has a valuation role, providing investors with information for making informed investment decisions, especially in capital allocation. Private-equity firms require accounting information to control the conflicts of interest both within the private-equity firm (between the general and limited partners) and within their investors. Controlling these conflicts shifts the role of accounting back toward its original stewardship roots [15]. The role of accounting information's can be viewed in shaping user perceptions by providing new evidence that the descriptive valence of accounting constructs can impact consumer purchase decisions [16].

The aim of this paper is to propose an aggregated index for evaluation the financial performance, based on 11 selected financial rates. The paper also highlights the role that accounting information holds in a firm in financial decisions making of investors and managers, aimed at strengthening of the financial performance and value of firm. The aggregated index proposed for evaluation financial performance provides relevant information for stakeholders, investors, business partners, banks or other financial institutions, financial analysts, as well for researches that can use these indicators in financial analysis, research studies and forecasting activities. Also this aggregated index can establish a hierarchy of the companies acting in a certain sector. In this paper, for experimental part we have chosen the textile industry from Romania, which is not discussed in extensive studies in economics, thus making important contributions to the studied field.

\section{METHODOLOGY}

In order to make strategic decisions in firms, Mereuţă [17] proposed the CEMATT method that is a multi-criteria diagnostic tool for the condition of a firm, based on 6 components: financial, marketing, technology, quality, general management and human resources [18]. We consider that most of the strategic decisions in firms are based on accounting information that underlies the calculation of financial indicators used for assessing the financial performance of firms; this is key information for managers, investors and creditors. We know that financial position of a firm is highlighted by the relationship between assets, liabilities and equity that show a certain level of financial performance. Information about all these financial structures is provided by the Balance sheet and Profit and Loss account of firms. Thus, for our aggregated index we selected a number of 11 indicators, described in table 1.

These 11 indicators selected are usually used in financial diagnosis that is a tool oriented towards users aiming at measuring the return on capital and risk, the assessment of the conditions for achieving financial balance and the degree of autonomy, that are important in decision making in firms related to suspending activities, redefining the strategy or policy on long-term or short-term. The majority of the indicators included in the aggregated index are internationally recognized and used individually in financial performance analysis: profitability as return on assets and return on equity, financial autonomy [19], liquidity [19-20], ownership structure [21-22], capital structure and risk management [21]; debt [22], size [23], sales [24] etc.

The evaluation mechanism of the aggregated index goes on the principle that each criterion $i$ in the aggregated index sets a number of points (score) $S_{i}$, where $i=1 \div 11$ with the characteristic that $S_{i}$, belongs to the set $S_{j}=\{20,40,60,80,100\}$ specific for each criterion. The minimum element of the set, namely 20 , is the score given to a criterion which is a statement of total or nearly-total maladjustment to the requirements of a market economy; the maximum score $S_{i}$, set is 100 and represents a case of satisfying a requirement at high-international level. In order to grant these scores $S_{i}$, for each criterion $i$ were established intervals of performance (table 2), according to the limits and favourable values of each indicators known from the financial literature.

After awarding scores, it can be achieved the classification of companies after financial performance by determining the aggregate index for each firm. The aggregate index of each firm is a weighted average of the scores $S_{i}$ granted to each criterion $i$ of the aggregated index, having as weighting coefficients 


\section{INDICATORS INCLUDED IN THE AGGREGATED INDEX}

\begin{tabular}{|c|c|c|}
\hline No. & Indicators & Indicators description \\
\hline 1. & Return on assets (ROA) & Operating results $\times 100 /$ Total assets \\
\hline 2. & Return on equity (ROE) & Net results $\times 100 /$ Equity \\
\hline 3. & Invested capital productivity (ICP) & Net sales $\times 100 /$ Fixed assets \\
\hline 4. & Long-term debt ratio (LTDR) & Long-term debts $\times 100 /$ (Long-term debts + Equity) \\
\hline 5. & $\begin{array}{l}\text { Long-term debts scaled to self-financ- } \\
\text { ing capacity (LTDSFC) }\end{array}$ & Long-term debts $\times 100 /$ Self-financing capacity \\
\hline 6. & Patrimonial liquidity (PL) & $\begin{array}{l}\text { (Current assets + Prepaids) } \times 100 /(\text { Current liabilities }- \text { Revenues in } \\
\text { advance) }\end{array}$ \\
\hline 7. & Current assets turnover (CAT) & (Current assets + Prepaids) $\times 365 /$ Net sales \\
\hline 8. & Reduced liquidity $(\mathrm{RL})$ & (Current assets + Prepaids - Inventories) $\times 365$ / Current liabilities \\
\hline 9. & Patrimonial solvability (PS) & Equity $\times 100 /$ Total liabilities \\
\hline 10. & Quick ratio (QR) & Cash and cash equivalent $\times 100 /$ Current liabilities \\
\hline 11. & Financial leverage (FL) & Long-term debts $\times 100 /$ Equity \\
\hline
\end{tabular}

Note: Self-financing capacity is determined as Net income + Depreciation \& Amortization.

\begin{tabular}{|l|c|c|c|c|c|c|}
\hline \multicolumn{9}{|c|}{ SCORES FOR INDICATORS VALUE } \\
\hline \multirow{2}{*}{ No. } & \multicolumn{1}{|c|}{ Criterion designation } & \multicolumn{4}{c|}{ Indicators scores } \\
\cline { 3 - 7 } & \multicolumn{2}{|c|}{20} & 40 & 60 & 80 & 100 \\
\hline 1. & ROA (should not decrease below 10\%) & $<4$ & $(4-10]$ & $(10-15]$ & $(15-20]$ & $>20$ \\
\hline 2. & ROE (should not decrease below 5\%) & $<2$ & $(2-5]$ & $(5-10]$ & $(10-15]$ & $>15$ \\
\hline 3. & ICP (should not decrease below 2) & $<2$ & $(2-3]$ & $(3-4]$ & $(4-5]$ & $>5$ \\
\hline 4. & LTDR (should not increase over 80\%) & $>80$ & $(60-80]$ & $(40-60]$ & $(20-40]$ & $<20$ \\
\hline 5. & LTDSFC (should not increase over 4) & $>22$ & $(22-16]$ & $(16-10]$ & $(10-4]$ & $<4$ \\
\hline 6. & PL (should not decrease below 1,30) & $<1.30$ & $(1.30-1.80]$ & $(1.80-2.30]$ & $(2.30-2.80$ & $>2.80$ \\
\hline 7. & CAT & $>320$ & $(290-320]$ & $(160-290]$ & $(30-160]$ & $<30$ \\
\hline 8. & RL (should not be lower than 1) & $<1.00$ & $(1.00-1.20]$ & $(1.20-1.40]$ & $(1.40-1.60]$ & $>1.60$ \\
\hline 9. & PS & $<25$ & $(25-50]$ & $(50-75]$ & $(75-100]$ & $>100$ \\
\hline 10. & QR & $<0.25$ & $(0.25-0.50]$ & $(0.50-0.75]$ & $(0.75 \mathrm{v} 1.00]$ & $>1.00$ \\
\hline 11. & FL (should not increase above 1) & $>1.75$ & $(1.75-1.50]$ & $(1.50-1.25]$ & $(1.25-1.00]$ & $<1.00$ \\
\hline
\end{tabular}

the coefficients of importance $K_{i}$ of each criterion $i$, that are set according to the degree of importance:

$-K_{i}=5$ for a very important criterion, that means consequences of failure are extremely serious for the whole accomplishment. There were considered very important criteria: ROE, LTDR, LTDSFC, RL and QR; $-K_{i}=2$ for a major criterion, that means consequences of failure are severe but only at the level of sections or departments. There were considered major criteria: ROA and $\mathrm{FL}$;

- $K_{i}=1$ for a secondary criterion, that means consequences of failure have isolated effects. There were considered secondary criteria: ICP, PL, CAT and PS. The degree of importance in establishing the coefficients was determined in accordance with the aim of the paper, that is the assessment of the level of financial performance of firms and the sector using the proposed aggregated index, and also establishing a hierarchy between companies acting in the sector, that can be used for decision making of managers, investors and creditors. The scale 5, 2 and 1 chosen for the degree of importance was maintained similar with the specifications from CEMATT model. The aggregated index of financial performance $\left(S_{F P}\right)$ is calculated by the relation:

$$
S_{F P}=\sum_{i=1}^{n} K_{i} \times S_{i} / \sum_{i=1}^{n} K_{i}
$$

After this aggregate score of financial performance, firms can be included in the following categories: (i) [0-20] - masked bankruptcy - detection of profit centres and triggering procedures for firm cession; (ii) (20-40] - critical situation - radical restructuring, taking measures for overcoming the "alarm thresholds", significant restrictions of activity, important changes of profile/markets, capital inflows; (iii) (40-60] - difficult balance - major restructuring, new targets in the short/medium term, commercial marketing activities, improving management and drastic 
savings regime, capital inflows; (iv) (60-80] - satisfactory adaptation - selection of strategic objectives, "freezing" unprofitable businesses, capital inflows; (v) (80-100] - validity in competitive environments adopting a firm offensive strategy in this case major restructuring is not necessary.

\section{EXPERIMENTAL WORK}

The methodology presented for evaluation financial performance is applied on firms acting in textile industry. The apparel and textile industry is one of the longest and most complicated industrial chains in manufacturing industry. It is fragmented and dominated by SME's, with a demand driven mainly by three end-uses: clothing, home and technical textiles. This industry is composed of a wide number of subsectors, covering the entire production cycle from the production of raw material to semi processed and final products [25].

Textile industry an important sector of national economy, both in terms of the contribution to gross domestic product and export growth, and in Romania has undergone in the last 20 years a difficult period of transformation and adaptation to a changing market. Romania is endowed with the necessary resources for the production of fibers and fiber silk and wool, flax and hemp bastfibers, but it still needs huge investments. Therefore, the industry is dependent on imports of raw materials [26].

We have chosen for case study the textile and clothing industry because, in Romania, is an industry with tradition and companies operating for over 100 years. Romania's competitive advantage in textile industry reported to the European one, is mainly due to lowcost labor force [26], creation of a great number of jobs, especially female, contribution to social stability being represented in all counties, skilled and experienced staff, proximity to Western countries, no taxes in EU membership and compliance with EU standards and regulations [27]. It is a sector that uses intensive labour force and has a significant share in the export economy and contributes with profit to the foreign trade balance of the country. According to the classification of value added per employee, Romania occupies the last place ahead of Bulgaria and the value added to total labor costs in industry exceeds the EU average for textile and clothing [28]. The production of textile clothing in Romania has recorded approximately 2.5 billion EUR in 2013 , up by almost $4 \%$ compared to 2012. Although during the first 8 months of 2014 , the turnover value index in textile manufacturing sector has increases by $16.4 \%$ compared to the same period of 2013 [27]. Romania has a very small share in the turnover of the EU, compared to the large number of employees in this industry. Romania has the largest undeveloped export potential in the textile industry of the EU countries, about $15 \%$ of the entire EU unexploited potential [28]. Study data were selected from Amadeus database, provided by Bureau van Dijk Electronics, from among medium-sized enterprises, active in 2014 in the clothing industry in Romania (with a number of employees between 50 and 249), with activity conducted within the NACE code 14 - Manufacture of wearing apparel (14.13). Thus, 366 active companies were identified in the database, 20 of which have been removed, for which the database does not provide comprehensive data. Of the 346 valid businesses, further on in the study, we will focus only on the first 82 mediumsized companies with total assets greater than 1 million Euro, that represents $23.70 \%$ of the active medium-sized firms in textile industry in Romania. For the sample of 82 companies were calculated indicators defined in table 1 using data from the database built for this study. The results are presented in Appendix (table 4). It was found that, in most cases, the analysed indicators are not within the normal ranges found in industry. For example, in the case of many firms, we have indicators greater than $5 \%$, when return on equity was determined, or greater than the maximum allowed recorded by the leverage ratio, which is $80 \%$. The examples that do not fit may continue in the case of patrimonial liquidity as well, where a normal value should not fall below 1.30. Misfit occurs in the case of patrimonial liquidity, where a normal value should be between 1.5 and 2, and in the case of solvency values, greater values than 1 must exist. But nevertheless, there are only 4 companies from 82 that fall within the normal range to all criteria.

In relation to the analysed companies, the scores awarded can be viewed in the Appendix (table 5) for the sector and for each firm. For the sector, basic indicators were determined adding the value registered by all firms included in the sample, the average score of the sector being 73.33. Please note that the range of variation was determined by the authors to frame the companies within the analysed indicators and equally depending on the specific of textile industry. Thus, for each firm, the scores for each indicator were granted, depending on the scale described on methodology. In Appendix (table 5), companies were ranked by the aggregate score obtained, in descending order, for a better observation of the position each firm. We found that the companies' situation is a good one seen in terms of the aggregate scores, although many of the 11 financial indicators fell outside the normal values in the industry.

\section{RESULTS AND DISCUSSION}

In table 3, we show the framing of companies after the level financial performance in a category of performance. Although the sector score determined as we presented above is framed on the interval (70-80] where we find the most companies; statistically, the average score of performance is 66.32 and standard deviation is 19.284. We can conclude that most medium-sized companies in the textile industry in Romania fall into the category 60-80, which means that companies operate under optimal conditions, and that could give them a very good rating. Also note that in the analysis there have not been registered companies classified in the lowest category, 
INTERVALS OF PERFORMANCE AFTER FIRMS' SCORES

\begin{tabular}{|c|c|}
\hline Firms score interval & No. of companies \\
\hline $\mathbf{( 9 0 - 1 0 0 ]}$ & 9 \\
\hline $\mathbf{( 8 0 - 9 0 ]}$ & 11 \\
\hline $\mathbf{( 7 0 - 8 0 ]}$ & 18 \\
\hline $\mathbf{( 6 0 - 7 0 ]}$ & 14 \\
\hline $\mathbf{( 5 0 - 6 0}]$ & 14 \\
\hline $\mathbf{( 4 0 - 5 0 ]}$ & 7 \\
\hline $\mathbf{( 3 0 - 4 0 ]}$ & 6 \\
\hline $\mathbf{( 2 0 - 3 0 ]}$ & 3 \\
\hline No. of companies & $\mathbf{8 2}$ \\
\hline
\end{tabular}

and so they may not be considered bankrupt. However, we believe that most companies are found to be working in normal operating parameters. Thus, over the sector score were found $42.68 \%$ of firms studied.

The results of the aggregated index are relevant for managers and owners that can find the position of their firm in the sector according to financial performance, can assess the evolution of financial performance in a certain period, can know the main competitors or the companies with similar financial performance, and also can forecast the financial performance for future years. Also, this information allows managers and owners to lead in decision making for improvement of financial performance. Financial analysts can realise comparative studies of financial performance between activity sectors and firms, for the same period (comparing different sectors and/or firms) and different periods of time (comparing the evolution of financial performance in the same sector and/or firm).

\section{CONCLUSIONS}

As a result, we conclude that the accounting information is really an important source for determining the financial position and performance of companies. In financial decision making at firm level, financial statements must be consulted, primarily the balance sheet and profit and loss account, which show the position, respectively the financial performance. It was found that the accounting information can be the key in decision making in the management of a firm. It also represents an important junction between the management, where decisions are made, and the finance, where financial situations are prepared. Thus, in conclusion, we say that the accounting information helps in making financial decisions within a firm.

This study was conducted on a database of middlesized companies in the Romanian textile industry after a selected criterion in order to determine the financial position and their relevance for theoreticians that can design on it financial models, and stakeholders that substantiate their decisions according to the firm performance. We proposed this aggregated index, based on financial indicators, in order to assess the financial performance of firms. We found that there was an almost equal ratio of firms in the first three categories, and no firm has been found bankrupt. We conclude on this case study indicating that the average firm score of the 82 companies is a good one, equal to 66.32 , so we can say that overall, medium-sized companies in the textile industry are in financial balance.

The idea of this research brings great benefits to theoreticians, researchers in economics and not only, but also to practitioners, to firms in order to achieve financial diagnosis, to identify financial problems and financial position within its field. Thus, managers can evaluate the financial performance of the firm in a certain period and can improve decision making when the financial performance of the firm decrease. The study offers relevant information for other stakeholders: for creditors, the firm score being a tool in granting funding process; for employees that search high labour productivity; for owners in order to make decision of investments or to take decisions for improving the firm performance; for suppliers, the high score of a firm indicating a good management and the desire to be business partner for such a firm; for government, this score being important in providing grants or subsidies for firm investments.

\section{BIBLIOGRAPHY}

[1] Ma, J., Evans, D., Fuller, R., Stewart, D. Technical efficiency and productivity change of China's iron and steel industry, In: International Journal of Production Economics, 2002, vol. 76, no. 3, pp. 293-312.

[2] Zhang, H., Li, L., Zhou, D., Zhou, P. Political connections, government subsidies and company financial performance: Evidence from renewable energy manufacturing in China, In: Renewable Energy, 2014, vol. 63, pp. 330-336.

[3] Chen, P., Yu, M., Chang, C., Hsu, S. Total factor productivity growth in China's agricultural sector, In: China Economic Review, 2008, vol. 19, no. 4, pp. 580-593.

[4] Yua, W., Ramanathan, R., Nath, P. The impacts of marketing and operations capabilities on financial performance in the UK retail sector: A resource-based perspective, In: Industrial Marketing Management, 2014, vol. 43, pp. 25-31.

[5] Chen, C.-M., Chang, C.-L. Diversification strategy and financial performance in the Taiwanese hotel industry, In: International Journal of Hospitality Management, 2012, vol. 31, pp. 1030-1032.

[6] Barros, C.P., and Peypoch, N. An evaluation of European airlines'operational performance, In: International Journal of Production Economics, 2009, vol. 122, no. 2, pp. 525-533. 
[7] Ongore, V.O., Kusa, G.B. Determinants of financial performance of commercial banks in Kenya, In: International Journal of Economics and Financial Issues, 2013, vol. 3, no. 1, pp. 237-252.

[8] Mukherjee, K., Ray, S., Miller, S. Productivity growth in large US commercial banks: the initial post-deregulation experience, Journal of Banking and Finance, 2001, vol. 25, pp. 913-939.

[9] Adams, M., Buckle, M. The determinants of corporate financial performance in the Bermuda insurance market, In: Applied Financial Economics, 2003, vol. 13, pp. 133-143.

[10] Sadka, R. Liquidity risk and accounting information, In: Journal of Accounting and Economics, 2011, vol. 52, no. 2-3, pp. 144-152.

[11] Huefner, R.J., Largay, J.A. The role of accounting information in revenue management, In: Business Horizons, 2008, vol. 51, no. 3, pp. 245-255.

[12] Bushman, R., Chen, Q., Engel, E., Smith, A. Financial accounting information, organizational complexity and corporate governance systems, In: Journal of Accounting and Economics, 2004, vol. 37, pp. 167-201.

[13] Danos, P., Holt, D.L., Imhoff, E. Jr. The use of accounting information in bank lending decisions, In: Accounting Organizations and Society, 1989, vol. 14, no. 3, pp. 235-246.

[14] Hall, M. Accounting information and managerial work, In: Accounting, Organizations and Society, 2010, vol. 35, no. 3, pp. 301-315.

[15] Zimmerman, J.L. The role of accounting in the twenty-first century firm, In: Accounting and Business Research, 2015, vol. 45, no. 4, pp. 485-509.

[16] Tian, Y., Zhou, H. From bottom line to consumers' mind: The framing effects of accounting information, In: Accounting, Organizations and Society, 2015, vol. 43, pp. 56-66.

[17] Mereuţă, C. Analiza diagnostic a societăţilor comerciale în tranziţie: Metoda CEMATT, 1994, Bucharest: Tehnica.

[18] Alexa, V., Kiss, I., Ratiu, S. Diagnostic analysis - tool in research and innovation, In: Annals of Faculty Engineering Hunedoara, 2013, vol. 11, pp. 321-324.

[19] Horta, I.M., Camanho, A.S., Moreira da Costa, J. Performance assessment of construction companies: A study of factors promoting financial soundness and innovation in the industry, In: International Journal of Production Economics, 2012, vol. 137, no. 1, pp. 84-93.

[20] Gurbuz, A.O., Aybars, A., Kutlu, O. Corporate governance and financial performance with a perspective on institutional ownership: empirical evidence from Turkey, In: Journal of Applied Management Accounting Research, 2010, vol. 8, pp. 21-38.

[21] Mirza, S.A., Javed, A. Determinants of financial performance of a company: Case of Pakistani stock market, In: Journal of Economics and International Finance, 2013, vol. 5, no. 2, pp. 43-52.

[22] Saliha, T., Abdessatar, A. The determinants of financial performance: an empirical test using the simultaneous equations method, In: Economics and Finance Review, 2011, vol. 1, no. 10, pp. 01-19.

[23] Love, I., Rachinsky, A. Corporate governance, ownership and bank performance in emerging markets: evidence from Russia and Ukraine, Siteresources-worldbank. 2007, Working Paper.

[24] Forbes, K.J. How do large depreciations affect company performance?, In: IMF Staff papers, Palgrave Macmillan, 2002, vol. 49, no. 1, pp. 214-238.

[25] Adinolfi, R., Andersen, T. In-depth assessment of the situation of the T\&C sector in the EU and prospects, In: Final Report ENTR/2010/16 Prepared for European Commission Enterprise and Industry DG, October 2011.

[26] Şerbănel, C.I. Romanian textile industry and its competitive advantage, In: SEA - Practical Application of Science, 2014, vol. 2, no. 2 (4), pp. 395-404.

[27] FRD Centre Market Entry Services, Garments Market in Romania, 2015, available at http://www.frdcenter.ro/assets/ Garments-Market-Romania-2015-DEMO-Sector-Brief.pdf

[28] Gîrneaţă, A. Increasing managerial capability in Romanian textile companies, In: Proceedings of the $7^{\text {th }}$ International Management Conference "New Management for the New Economy", November 7th-8th, 2013, Bucharest, Romania.

\section{Authors:}

\section{TEODOR HADA ${ }^{1}$, NICOLETA BĂRBUŢ̆-MIŞU², TEODORA MARIA AVRAM}

1"Bogdan Vodă" University, Faculty of Economic Sciences, Department of Management-Finance-Accounting, 26A Grigore Alexandrescu, 400560, Cluj-Napoca, Romania

2“Dunarea de Jos” University of Galati, Faculty of Economics and Business Administration, Department of Business Administration, 800008, Galati, Romania

3“1 Decembrie 1918" University, Faculty of Economic Sciences, PhD Student, 5 Gabriel Bethlen, 510009, Alba Iulia, Romania

e-mail: teohada@yahoo.com; Nicoleta.Barbuta@ugal.ro; avram_teodora@ymail.com

Corresponding author:

NICOLETA BĂRBUŢ̆-MIŞU

e-mail: Nicoleta.Barbuta@ugal.ro 


\title{
A comparative study on handle properties of bamboo and cotton fabrics
}

DOI: $10.35530 / I T .070 .03 .1538$

GAMZE SÜPÜREN MENGÜÇ

EYLEN SEMA DALBAŞI

ARIF TANER ÖZGÜNEY

NILGÜN ÖZDIL

\author{
REZUMAT - ABSTRACT
}

Studiu comparativ al tușeului țesăturilor din bambus și bumbac

Emolienții sunt de mare importanță în prelucrarea textilelor. Scopul acestui tratament este de a obține un tușeu moale pentru a facilita capacitatea de prelucrare și a îmbunătăți gradul de uzură. În acest studiu, s-a urmărit investigarea efectului și durabilității spălării diferiților emolienți asupra proprietăților tușeului țesăturilor tricotate din bumbac și bambus. Au fost aplicate șase tipuri de emolienți pe țesături. Mai mult, a fost testată durabilitatea tratării cu emolienți după 5,10 și 20 cicluri de spălare. Au fost măsurate caracteristicile tușeului, cum ar fi: drapajul, coeficientul de frecare cinetică și rigiditatea la indoire circulară. Rezultatele au fost evaluate statistic. S-a constatat că tratamentul de emoliere nu are o performanță de succes pentru țesăturile de bambus, așa cum se întâmplă în cazul țesăturilor de bumbac.

Cuvinte-cheie: bumbac, bambus, emolient, drapaj, frecarea suprafeței, spălare

A comparative study on handle properties of bamboo and cotton fabrics

Softeners are of great importance in textile processing. The aim of this treatment is to achieve a soft handle to facilitate the processability and improve wettability. In this study, it was aimed to investigate the effect and washing durability of various softeners on handle properties of cotton and bamboo knitted fabrics. Six types of softeners were applied to the fabrics. Moreover, the washing durability of the softeners after 5, 10 and 20 washing cycles were tested. Handle characteristics such as drapeability, kinetic friction coefficient and circular bending rigidity were measured. The results were statistically evaluated. It was determined that softening treatment does not have a successful performance in bamboo fabrics as it has in cotton fabrics.

Keywords: cotton, bamboo, softener, drapeability, surface friction, washing

\section{INTRODUCTION}

Cotton is one of the most commonly used textile fibers in the world. It is comfortable and has soft handle, good color and printing properties. It is predicted that cotton's consumption will be approximately 30 million tons by 2020 [1-6].

A regenerated cellulosic fiber bamboo has recently been of great interest due to its several advantages. Bamboo fibers have good characteristics such as moisture vapor transmission, good dyeability, soft hand, high moisture absorption capacity and pleasant luster. Bamboo fiber is consisted of cellulose (57-63\%) with a $\alpha$-cellulose content of $36-41 \%$, lignins (22-26\%) and penthosans (16-21\%) [7-10]. Softeners can provide textiles an agreeable soft hand, some smoothness, more flexibility, better drape and pliability. Softeners are classified according to their ionic character as cationic, anionic, non-ionic, amphoteric, and silicone [11-13]. The hydrophilic parts of the cationic softener contain quaternary ammonium, which adsorb negatively charged fiber surfaces. The long aliphatic chains are then oriented towards outside of the fiber and act as an excellent boundary lubricant between yarns and fibers [14].

Anionic softeners have nowadays only a very limited use in textile processing, due to their low substantivity and minor softness. Some examples of their uses include raising and sanforising processes, which result in improved smoothness/antistatic and rewetting properties, respectively.

Non-ionic softeners theoretically have no electric charge and for that reason show no significant substantivity. They can be easily combined with other active agents or products, are stable against high temperatures and are non-yellowing. For that reason, this product group is ideal for the finish of opticallybrightened white textiles [15].

Silicones became popular in the textile industry in the early 1960s. The first products were mainly polydimethylsiloxanes without modification. A breakthrough came in the 1970s with the development of aminofunctional polydimethylsiloxanes, which are the most advanced silicone softeners [16]. Silicones are polymers with backbones that consist of alternating oxygen and silicon atoms. The silicon-oxygen bonds are strong and very flexible compared to the carboncarbon bonds found in the backbones of other polymers. The general structure of the silicone softener can be seen in figure 1 .

The flexibility of the siloxane backbone means that at an interface the methyl groups can always be presented to the outside world, creating a very low surface energy material. The silicone softeners are classified as polydimethylsiloxanes, amido, amino functional silicones, methyl hydrogen silicones, epoxy functional silicones, hydroxyl functional silicones, silicone polyethers, epoxy polyether silicones [17-19]. 


$\begin{gathered}\mathrm{Me} \\ 1 \\ \text { Reactive Group - } \mathrm{Si} \\ 1 \\ \mathrm{Me}\end{gathered} \quad \mathrm{O}-\left[\begin{array}{l}\text { Reactive Group } \\ 1 \\ \mathrm{Si}-\mathrm{O} \\ 1 \\ \text { Functional Group }\end{array}\right]\left[\begin{array}{l}\mathrm{Me} \\ 1 \\ \mathrm{Si}-\mathrm{O}- \\ 1 \\ \mathrm{Me}\end{array}\right] \mathrm{Si}$ - O - Reactive Group

Fig. 1. General structure of a silicone softener [17]

Functional group: Amino Ethyl, Amino Propyl, Amido, Glycol, Vinyl, Quaternary, Hydroxyl

Reactive group: Methoxy, Ethoxy, $\mathrm{OH}, \mathrm{H}$ $\mathrm{X}, \mathrm{Y}$ : number of monomeric units

According to the literature review, it can be stated that, there are several studies indicating the effect of softeners on cotton fabrics [13, 15, 20-22]. However, there is not a comprehensive research, which includes cationic, non-ionic, anionic softeners and silicones on bamboo fabrics. Therefore, the importance of this study is to investigate systematically the effects of different softeners on drape and friction properties of cotton and bamboo knitted fabrics. Furthermore, the washing durability of the used softeners after 5, 10 and 20 washing cycles were examined.

\section{MATERIALS AND METHODS}

In this study $100 \%$ cotton and $100 \%$ bamboo (regenerated) yarns in 20 Tex yarn count and in $\alpha_{m}=120$ twist coefficient were used. They were knitted in interlock structure in the same density $(27 \mathrm{wpc}$ and $15 \mathrm{cpc}$ ) by using the FOUQUET 18E gauge knitting machine.
After the fabrics were pre-treated and dyed, six different softeners were applied to these fabrics by padding method. All the softeners were commercial chemicals supplied from Rudolf Duraner Company.

Rapid Model PA-1 marked laboratory padder was used for impregnation and Ataç GK4 marked laboratory stenter was used for drying. The chemical structures and types of used softeners and the application recipes are given in table 1 .

After the applications, the untreated and treated samples were washed at the Wascator machine according to ISO 6330 standard (5A program) and dried by lying. The washing cycles were selected as 5,10 and 20.

Before the tests, fabric samples were conditioned under standard atmosphere conditions $\left(20^{\circ} \mathrm{C} \pm 2^{\circ} \mathrm{C}\right.$ temperature, $65 \% \pm 4 \% \mathrm{RH}$ ). Afterwards, characteristics such as thickness, mass per unit area, drapeability, friction coefficients, circular bending rigidity were measured.

The fabric drapeability test was carried out by using Cusick Drape Tester according to BS EN ISO 9073-9 (figure 2,a). The fabric drapeability tests were repeated six times. In the drape test, a circular specimen is held concentrically between two smaller horizontal discs and is allowed to drape into folds under its own weight. A light is shone from underneath the specimen and the shadow that of the fabric casts. The stiffer a fabric is, the larger is the area of its shadow compared with the unsupported area of the fabric.

Table 1

\begin{tabular}{|l|l|l|}
\hline \multicolumn{3}{|c|}{ THE APPLICATION RECIPES OF THE SOFTENERS } \\
\hline \multicolumn{1}{|c|}{ Definition } & \multicolumn{1}{|c|}{ Softener type } & \multicolumn{1}{c|}{ Treatment conditions } \\
\hline UT & Untreated fabric (only pretreated and dyed fabric) & - \\
\hline Softener 1 (S1) & Micro-dispersed poly-amino siloxane & $30 \mathrm{~g} / \mathrm{l}, \mathrm{pH}: 5.5-6$ (Acetic acid) \\
\hline Softener 2 (S2) & Macro-emulsion of elastomeric poly-amino siloxane & $30 \mathrm{~g} / \mathrm{l}, \mathrm{pH}: 4.5-5.5$ (Acetic acid) \\
\hline Softener 3 (S3) & Nano-emulsion of elastomeric polyaminosiloxane & $30 \mathrm{~g} / \mathrm{l}, \mathrm{pH}: 4.5-5$ (Acetic acid) \\
\hline Softener 4 (S4) & Cationic softener, Carbamide derivative & $30 \mathrm{~g} / \mathrm{l}, \mathrm{pH}: 4-5$ (Acetic acid) \\
\hline Softener 5 (S5) & Nonionic softener, Polyethylene emulsion & $30 \mathrm{~g} / \mathrm{l}, \mathrm{pH}: 6-7$ (Acetic acid) \\
\hline Softener 6 (S6) & Carbamino derivative and reactive polysiloxanes & $30 \mathrm{~g} / \mathrm{l}, \mathrm{pH}: 4.5-5$ (Acetic acid) \\
\hline Impregnation conditions: Pick up value: 75 \%, Drying: 130C for 3 min. & \\
\hline
\end{tabular}

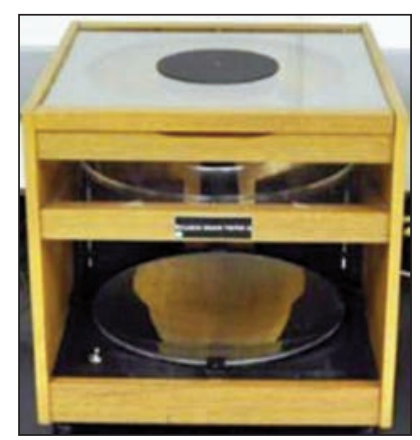

a

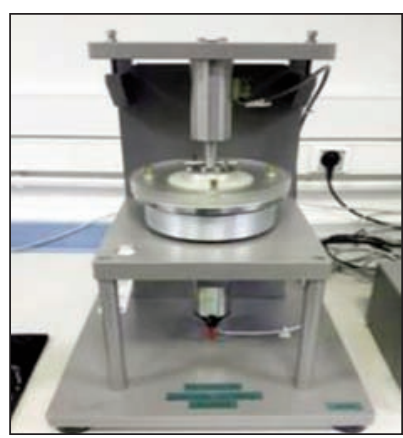

b

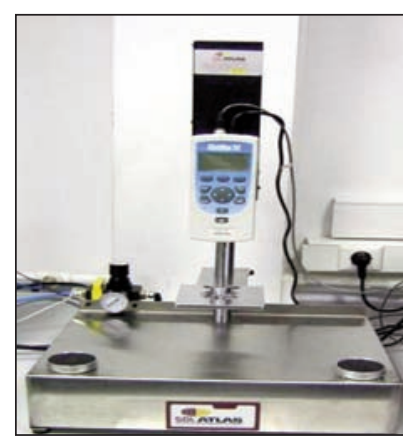

c

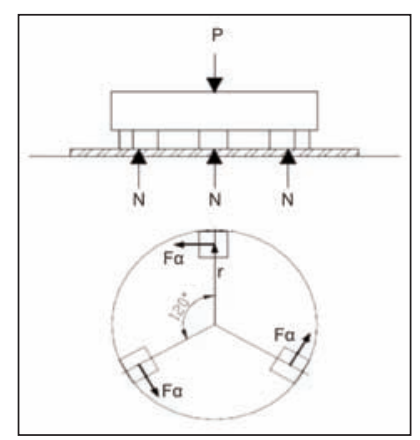

d

Fig. 2. Cusick Drape Tester (a), Frictorq instrument (b), SDL Atlas Digital Pneumatic Stiffness Tester (c), measurement principle of Frictorq $(d)$ 
The drape coefficient can then be calculated using the following equation:

Drape coefficient $=\frac{\text { mass of shaded area }}{\text { total } \text { mass of paper ring }} \times 100$

The higher the drape coefficient a fabric has, the lower drapeability and stiffer the fabric gets.

The circular bending rigidity of the fabrics was tested with SDL Atlas Digital Pneumatic Stiffness Tester (figure 2,c). During test some of the specimens could not be measured due to the low force value. In order to compare the stiffness values of the fabrics, six samples were prepared for each type of fabric according to ASTM D 4032 standard [24, 25].

In order to determine the kinetic friction coefficient of the experimental fabrics, Frictorq instrument (figure $2, b)$, which uses the torq principle was employed. Instrument is designed to measure the Coefficient of Friction, $\mu$, in 2D flexible structures such as woven fabrics, knitted fabrics, nonwovens and soft papers (tissue). In this model, friction coefficient is calculated from the friction reaction torque measured by means of a high sensitivity torque sensor, the normal load created by the contact sensor and a geometrical parameter (figure 2, $d$ ).

$$
T=3 F_{a} r
$$

Being, by definition, $F_{a}=\mu N$ and from figure 2, $d$, $N=P / 3$, where $P$ is the vertical load, the coefficient of friction is then expressed by [23]:

$$
\mu=\frac{T}{P \cdot r}
$$

After the drapeability, friction coefficient and circular bending rigidity measurements, the obtained results were evaluated statistically. ANOVA and StudentNewman-Keuls tests were conducted to determine whether the effect of fabric type, softening agents and washing cycles on fabric properties are statistically significant at $95 \%$ confidence level $(p<0.05)$

\section{RESULTS AND DISCUSSION}

\section{Dimensional properties results}

Results of mass per unit area and thickness properties of the fabrics are given in table 2 .

\begin{tabular}{|c|c|c|c|c|c|}
\hline \multirow{2}{*}{ Softener type } & & \multicolumn{2}{|c|}{ Mass per unit area $\left(\mathrm{g} / \mathrm{m}^{2}\right)$} & \multicolumn{2}{|c|}{ Thickness (mm) } \\
\hline & & BAMBOO & COTTON & BAMBOO & COTTON \\
\hline \multirow{4}{*}{ UT } & Before washing & 170.0 & 167.6 & 0.93 & 1.01 \\
\hline & 5 washing cycle & 171.9 & 174.7 & 1.03 & 1.14 \\
\hline & 10 washing cycle & 172.2 & 174.4 & 1.05 & 1.14 \\
\hline & 20 washing cycle & 169.2 & 173.0 & 1.04 & 1.12 \\
\hline \multirow{4}{*}{ S1 } & Before washing & 159.7 & 165.5 & 0.85 & 0.96 \\
\hline & 5 washing cycle & 156.4 & 172.7 & 1.00 & 1.14 \\
\hline & 10 washing cycle & 165.3 & 176.9 & 1.01 & 1.15 \\
\hline & 20 washing cycle & 173.0 & 171.4 & 1.08 & 1.12 \\
\hline \multirow{4}{*}{$\mathrm{S} 2$} & Before washing & 159.2 & 170.0 & 0.85 & 0.96 \\
\hline & 5 washing cycle & 170.6 & 182.3 & 1.05 & 1.16 \\
\hline & 10 washing cycle & 158.9 & 182.9 & 1.00 & 1.18 \\
\hline & 20 washing cycle & 163.7 & 182.3 & 1.07 & 1.15 \\
\hline \multirow{4}{*}{ S3 } & Before washing & 160.8 & 168.6 & 0.76 & 0.99 \\
\hline & 5 washing cycle & 170.2 & 181.1 & 0.98 & 1.15 \\
\hline & 10 washing cycle & 170.8 & 178.0 & 1.05 & 1.14 \\
\hline & 20 washing cycle & 161.8 & 168.6 & 1.00 & 1.10 \\
\hline \multirow{4}{*}{ S4 } & Before washing & 156.7 & 166.0 & 0.80 & 0.97 \\
\hline & 5 washing cycle & 165.6 & 171.4 & 1.02 & 1.14 \\
\hline & 10 washing cycle & 165.9 & 173.9 & 1.02 & 1.14 \\
\hline & 20 washing cycle & 169.3 & 168.3 & 1.01 & 1.07 \\
\hline \multirow{4}{*}{ S5 } & Before washing & 160.5 & 163.2 & 0.81 & 0.94 \\
\hline & 5 washing cycle & 177.3 & 174.1 & 1.12 & 1.11 \\
\hline & 10 washing cycle & 177.3 & 173.9 & 1.14 & 1.13 \\
\hline & 20 washing cycle & 175.8 & 176.8 & 1.10 & 1.11 \\
\hline \multirow{4}{*}{ S6 } & Before washing & 159.4 & 161.2 & 0.77 & 0.96 \\
\hline & 5 washing cycle & 170.3 & 176.4 & 1.01 & 1.11 \\
\hline & 10 washing cycle & 173.3 & 172.4 & 1.06 & 1.12 \\
\hline & 20 washing cycle & 169.5 & 171.5 & 1.09 & 1.08 \\
\hline
\end{tabular}

DIMENSIONAL PROPERTIES OF THE FABRICS AFTER SOFTENING TREATMENT AND WASHING CYCLES 
According to the results it can be stated that, fabric weight and thickness increase after washing processes. It is due to the shrinkage of the fabric, which occurs during the repeating washing cycles for all types of materials. Shrinkage is highest especially after the first 5 washing cycles. However, the mass and thickness generally decrease after the repeating washings.

\section{Drape coefficient results}

In order to determine the effect of softener types more sensitively, statistical evaluation was conducted on the results of the unwashed fabrics titled as "Before washing". Statistical evaluation of the washing and softeners effect on fabric drape was given in table 3 and table 4 respectively. It can be said that there is a significant difference between cotton and bamboo fabrics and washing cycles has an effect on the drape coefficient of the fabrics.

Table 3

\section{EFFECT OF FABRIC TYPE AND WASHING CYCLE ON FABRIC DRAPE}

\begin{tabular}{|c|c|c|c|c|c|}
\hline \multicolumn{3}{|c|}{ Fabric type } & \multicolumn{3}{|c|}{ Sig. } \\
\hline \multicolumn{3}{|c|}{ Bamboo fabrics } & \multirow{2}{*}{\multicolumn{3}{|c|}{0,000}} \\
\hline \multicolumn{3}{|c|}{ Cotton fabrics } & & & \\
\hline \multicolumn{6}{|c|}{ DRAPE COEFFICIENT } \\
\hline \multirow{2}{*}{$\begin{array}{c}\text { Washing } \\
\text { cycle }\end{array}$} & \multirow{2}{*}{$\mathbf{N}$} & \multicolumn{4}{|c|}{ Subset } \\
\hline & & 1 & 2 & 3 & \\
\hline 0 & 96 & 11.2 & & & \\
\hline 5 & 96 & & 13.3 & & \\
\hline 10 & 96 & & & 15.3 & \\
\hline 20 & 96 & & & & 17.9 \\
\hline Sig. & & 1.000 & 1.000 & 1.000 & 1.000 \\
\hline
\end{tabular}

Drape coefficient values of the bamboo fabrics are given in figure 3 . It is clearly seen that all bamboo fabrics have lower drape coefficient than cotton fabrics, indicating the high bending behavior and softness of the material. Because the lower the drape coefficient value is, the softer the fabric is. As the drape coefficient test results were analyzed in detail, it can be seen that washing process causes increase of the drape coefficient for both cotton and bamboo fabrics. It can be stated that the fabrics became stiffer

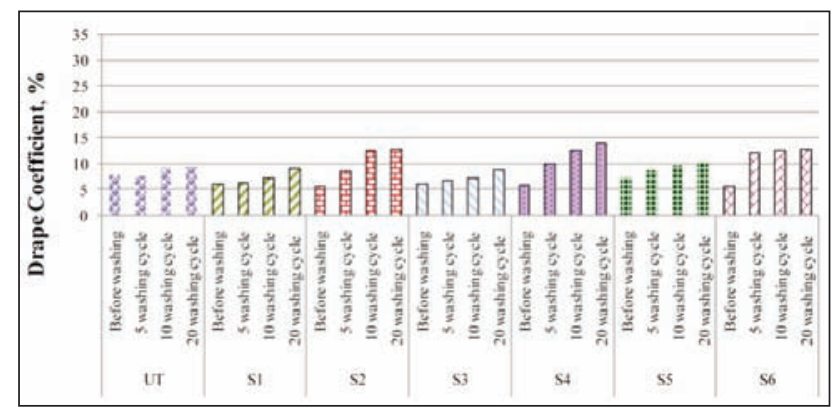

Fig. 3. Drape coefficient values of the bamboo fabrics

\begin{tabular}{|c|c|c|c|c|c|}
\hline & & & & & Table 4 \\
\hline EFF & ECT OF SOFTENE & TY & ON FA & BRIC D & RAPE \\
\hline & DRA & $\mathrm{CO}$ & FICIEI & & \\
\hline 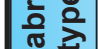 & Softener & $\mathbf{N}$ & & Subset & \\
\hline & type & & 1 & 2 & 3 \\
\hline & S6 & 6 & 5.67 & & \\
\hline of & S2 & 6 & 5.81 & & \\
\hline$\overline{\underline{m}}$ & S4 & 6 & 5.87 & & \\
\hline 巡 & S1 & 6 & 6.07 & & \\
\hline ○ & S3 & 6 & 6.07 & & \\
\hline$\sum$ & S5 & 6 & & 7.37 & \\
\hline m & Without softener & 6 & & 7.85 & \\
\hline & Sig. & & 0.499 & 0.063 & \\
\hline & S1 & 6 & 12.90 & & \\
\hline & S6 & 6 & & 14.78 & \\
\hline$\overline{\underline{n}}$ & S4 & 6 & & 14.92 & \\
\hline 近 & S3 & 6 & & 15.45 & \\
\hline z & S2 & 6 & & 15.64 & \\
\hline 点 & S5 & 6 & & 15.90 & \\
\hline 0 & Without softener & 6 & & & 24.32 \\
\hline & Sig. & & 1.000 & 0.094 & 1.000 \\
\hline
\end{tabular}

after washing process. The effect was found statistically significant (figure 2 and table 3 ). In case of softener, it can be stated that the fabrics became stiffer after washing process. Additionally, there is not a statistically significant change in fabric drapeability after the softening treatments for bamboo fabrics except the fabrics treated with softening agent S5, which is a nonionic softener.

Cotton fabrics exhibited the highest drape coefficient within all fabrics (figure 4). Compared to the bamboo fabrics, the effect of softeners can be seen clearly.

Drape coefficient values decrease after softening treatment for cotton fabrics as well. Softener S1, which is micro-silicone, has the highest effect among them. It was thought that after washing, micro-silicones cannot move away from fabric due to the low molecule size. Similar to the results of bamboo fabrics, softener S5 provided the lowest effect. Increased washing cycles causes increases in fabric stiffness as well.

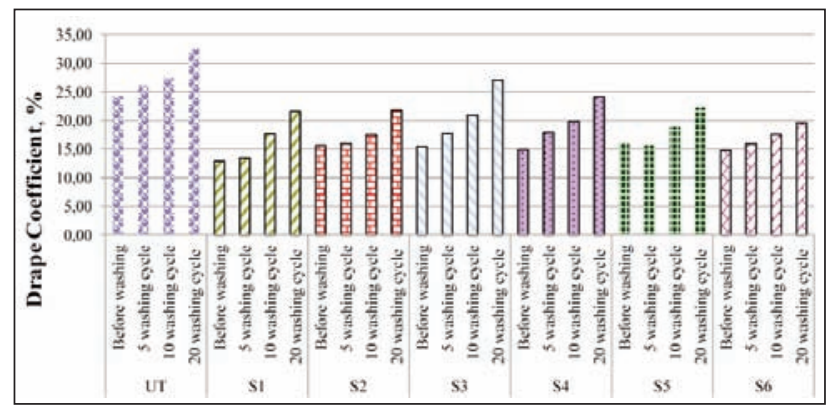

Fig. 4. Drape coefficient values of cotton fabrics 
Statistical evaluation of the effect of washing and softeners on friction properties of fabrics were given in table 5 and table 6 respectively. It can be said that there is a significant difference between cotton and bamboo fabrics and washing cycles have an effect on the friction coefficient of the fabrics.

Table 5

EFFECT OF FABRIC TYPE AND WASHING CYCLE ON FRICTION COEFFICIENT

\begin{tabular}{|c|c|c|c|c|}
\hline \multicolumn{3}{|c|}{ Fabric type } & \multicolumn{2}{c|}{ Sig. } \\
\hline \multicolumn{3}{|c|}{ Bamboo fabrics } & \multicolumn{2}{c|}{0,002} \\
\hline \multicolumn{3}{|c|}{ Cotton fabrics } & $\mathbf{3}$ \\
\hline \multicolumn{3}{|c|}{ FRICTION COEFFICIENT } \\
\cline { 1 - 3 } $\begin{array}{c}\text { Washing } \\
\text { cycle }\end{array}$ & $\mathbf{N}$ & $\mathbf{1}$ & $\mathbf{2}$ & $\mathbf{3}$ \\
\hline 0 & 84 & 0.3353 & & \\
\hline 20 & 84 & 0.3404 & & 0.3609 \\
\hline 10 & 84 & & 0.3530 & 1.000 \\
\hline 5 & 84 & & & 1.000 \\
\hline Sig. & & 0.056 & \\
\hline
\end{tabular}

According to the table 6 softening treatment do not increase surface smoothness, conversely increase the surface friction in most cases for bamboo fabrics. However, in cotton fabrics softening treatment provide significant decrease on surface friction.

Kinetic friction coefficient values of the fabrics were given in figure 5 and figure 6 . In case of washing cycles, kinetic friction coefficient values increased after 5 washing cycles and as the washing cycles increased, decline tendency was determined. These results were found parallel to the results of mass per unit area and it is due to the shrinkage of the fabrics. The shrinkage is higher after 5 times of washing, however, after 10 washing cycles hairiness on fabric surface is removed and surface fuzzes decrease. As a result of that, friction coefficient values decrease. As the effect of the softening agent was examined for unwashed fabrics, it can be stated that softening treatment causes an increase in the surface friction coefficient of the fabrics except for softening agent S6. The effect of softening treatment on friction coefficient of cotton fabrics can be seen in figure 6 . As all

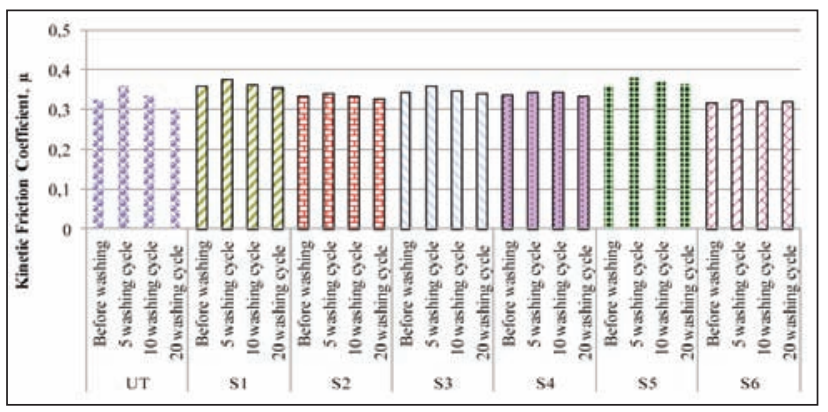

Fig. 5. Kinetic friction coefficient values of bamboo fabrics

\begin{tabular}{|c|c|c|c|c|c|c|}
\hline \multirow{4}{*}{ 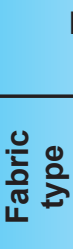 } & FECT OF & $\begin{array}{l}\mathrm{FTI} \\
\mathrm{CO}\end{array}$ & $\begin{array}{l}\text { NER T } \\
\text { FFICIE }\end{array}$ & $\begin{array}{l}\text { PE ON } \\
\text { NT }\end{array}$ & FRICTI & \\
\hline & \multicolumn{6}{|c|}{ FRICTION COEFFICIENT } \\
\hline & \multirow{2}{*}{$\begin{array}{c}\text { Softener } \\
\text { type }\end{array}$} & \multirow{2}{*}{$\mathbf{N}$} & \multicolumn{4}{|c|}{ Subset } \\
\hline & & & 1 & 2 & 3 & 4 \\
\hline \multirow{8}{*}{ 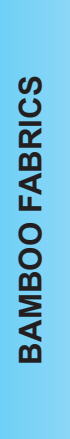 } & S6 & 6 & 0.318 & & & \\
\hline & $\begin{array}{l}\text { Without } \\
\text { softener }\end{array}$ & 6 & 0.323 & & & \\
\hline & $\mathrm{S} 2$ & 6 & & 0.333 & & \\
\hline & S4 & 6 & & 0.337 & 0.337 & \\
\hline & S3 & 6 & & & 0.344 & \\
\hline & $\mathrm{S} 1$ & 6 & & & & 0.358 \\
\hline & S5 & 6 & & & & 0.360 \\
\hline & Sig. & & 0.217 & 0.281 & 0.051 & 0.473 \\
\hline \multirow{8}{*}{ 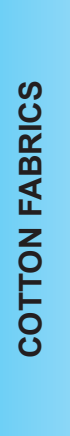 } & $\mathrm{S} 2$ & 6 & 0.319 & & & \\
\hline & S3 & 6 & 0.320 & & & \\
\hline & S4 & 6 & 0.322 & & & \\
\hline & S5 & 6 & & 0.332 & & \\
\hline & S6 & 6 & & 0.332 & & \\
\hline & S1 & 6 & & & 0.340 & \\
\hline & $\begin{array}{l}\text { Without } \\
\text { softener }\end{array}$ & 6 & & & & 0.350 \\
\hline & Sig. & & 0.713 & 0.958 & 1.000 & 1.000 \\
\hline
\end{tabular}

unwashed fabrics were considered, softeners S2, S3 and $\$ 4$ cause the highest decrease on the friction coefficient of the fabrics. This type of softeners provide smooth fabric surface. Softeners S5 and S6 have a moderate effect on decrease. Softener 1 has the lowest effect. However, it can be interpreted that softening treatment for cotton fabrics is effective in terms of kinetic friction coefficient. The change of the kinetic friction coefficients depending on the washing cycles are generally in the same tendency for all softener types and the changes are related with the fabric shrinkage. Softener 1 and 5 are not efficient on the surface properties of any of these fabrics.

\section{Circular bending rigidity test results}

Statistical evaluation of the effect of washing and softeners on bending rigidity properties of the fabrics was given in table 7 and table 8 respectively. It can

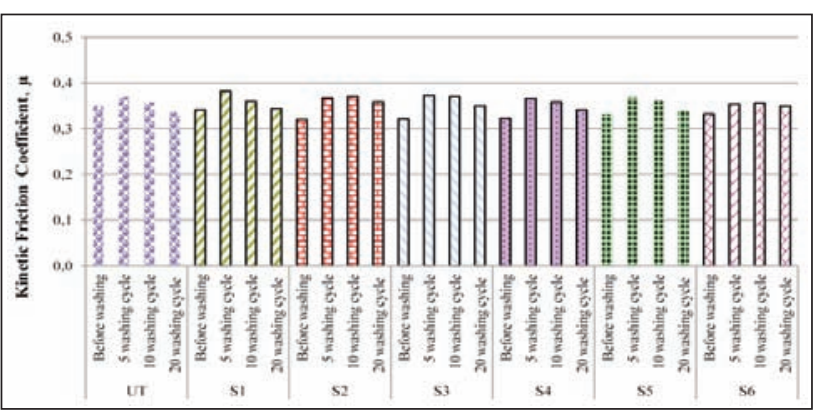

Fig. 6. Kinetic friction coefficient values of cotton fabrics 
be said that there is a significant difference between cotton and bamboo fabrics and washing cycles has an effect on the bending behavior of the fabrics.

Table 7

\begin{tabular}{|c|c|c|c|c|c|}
\hline \multicolumn{2}{|c|}{ Fabric type } & \multicolumn{3}{c|}{ Sig. } \\
\hline \multicolumn{3}{|c|}{ Bamboo fabrics } & \multicolumn{3}{c|}{0,000} \\
\hline \multicolumn{3}{|c|}{ Cotton fabrics } & \multicolumn{3}{c|}{ Subset } \\
\hline \multicolumn{5}{|c|}{ CIRCULAR BENDING RIGIDITY } \\
\cline { 1 - 5 } $\begin{array}{c}\text { Washing } \\
\text { cycle }\end{array}$ & $\mathbf{N}$ & $\mathbf{1}$ & $\mathbf{2}$ & $\mathbf{3}$ & $\mathbf{4}$ \\
\hline 0 & 42 & 3.02 & & & \\
\hline 5 & 42 & & 5.67 & & \\
\hline 10 & 42 & & & 6.85 & \\
\hline 20 & 42 & & & & 7.60 \\
\hline Sig. & & 1.000 & 1.000 & 1.000 & 1.000 \\
\hline
\end{tabular}

Table 8

\begin{tabular}{|c|c|c|c|c|c|c|}
\hline \multirow{3}{*}{ 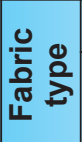 } & \multicolumn{6}{|c|}{ CIRCULAR BENDING RIGIDITY } \\
\hline & \multirow{2}{*}{$\begin{array}{l}\text { Softener } \\
\text { type }\end{array}$} & \multirow{2}{*}{$\mathbf{N}$} & \multicolumn{4}{|c|}{ Subset } \\
\hline & & & 1 & 2 & 3 & 4 \\
\hline \multirow{8}{*}{ 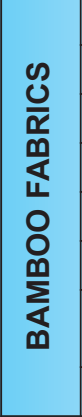 } & S3 & 3 & 1.10 & & & \\
\hline & S6 & 3 & 1.13 & & & \\
\hline & $\mathrm{S} 1$ & 3 & 1.23 & & & \\
\hline & S4 & 3 & 1.25 & & & \\
\hline & $\mathrm{S} 2$ & 3 & 1.33 & & & \\
\hline & S5 & 3 & & 1.75 & & \\
\hline & $\begin{array}{l}\text { Without } \\
\text { softener }\end{array}$ & 3 & & & 2.30 & \\
\hline & Sig. & & 0.072 & 1.000 & 1.000 & \\
\hline \multirow{8}{*}{ 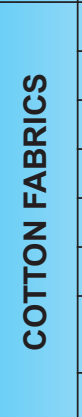 } & S1 & 3 & 3.62 & & & \\
\hline & S4 & 3 & 4.17 & 4.17 & & \\
\hline & S3 & 3 & 4.32 & 4.32 & & \\
\hline & S2 & 3 & 4.35 & 4.35 & & \\
\hline & S6 & 3 & & 4.53 & & \\
\hline & S5 & 3 & & & 4.90 & \\
\hline & $\begin{array}{l}\text { Without } \\
\text { softener }\end{array}$ & 3 & & & & 6.40 \\
\hline & Sig. & & 0.061 & 0.088 & 1.000 & 1.000 \\
\hline
\end{tabular}

Circular bending rigidity results of the fabrics were given in figure 7 and figure 8 . As the circular bending rigidity of the fabrics increases, fabric becomes stiffer. For all fabric types, circular bending rigidity gets higher as the washing cycles increase. It was determined that, cotton fabrics have higher circular bending rigidity than bamboo fabrics. It can be seen that all softeners have a significant effect on fabric rigidity, while softener S5 has the least influence. This is related with the lower substantivity of the non-ionic softener. The orientation of non-ionic softeners depends on the nature of the fiber surface, with the hydrophilic portion of the softener being attracted to hydrophilic surfaces and the hydrophobic portion being attracted to hydrophobic surfaces [11]. Similar

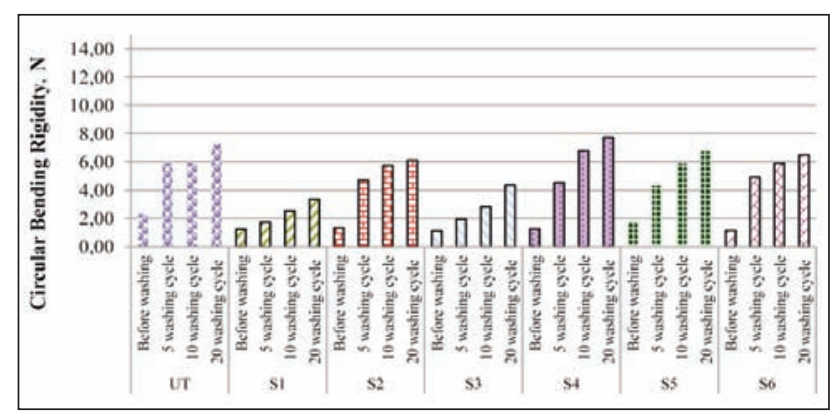

Fig. 7. Circular bending rigidity values of bamboo fabrics

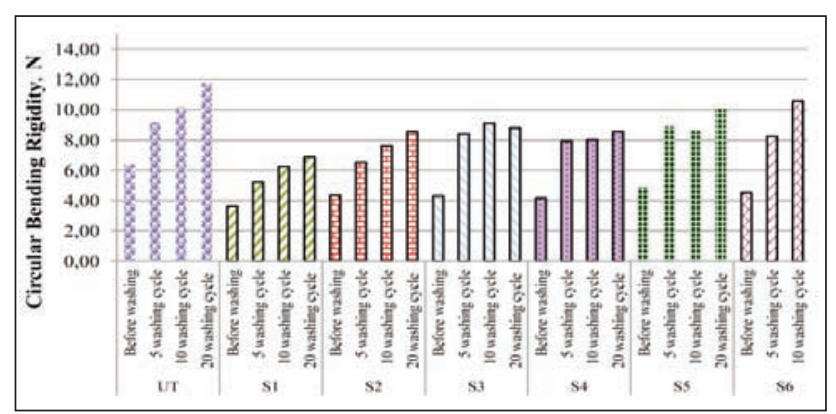

Fig. 8. Circular bending rigidity values of cotton fabrics

to the drape results except softener S5, there is not a significant effect of softener type on bending rigidity of bamboo fabrics.

\section{CONCLUSIONS}

Softening treatment is one of the most important processes in textile finishing. In this study, the purpose is to investigate washing durability and effect of various softeners on drape, kinetic friction coefficient and bending rigidity properties of cotton and bamboo knitted fabrics systematically. The obtained results can be summarized as follows:

- Bamboo fabrics and its blends have very soft handle and a smooth surface, whereas cotton fabrics are comparatively stiffer and have rougher surfaces. It was determined that softening treatment does not have the same effective softening performance on bamboo fabrics as it has on cotton fabrics. According to the circular bending rigidity results all softeners have a significant effect on fabric rigidity except softener 5 .

- The fabric weight and thickness increased after washing processes due to the shrinkage of the fabric.

- While softener 6 (carbamino derivative and reactive polysiloxanes) had better performance for bamboo fabrics, softener 1 (micro-silicone) was more efficient for cotton fabrics.

- An increase was found in kinetic friction coefficient of bamboo fabrics after softening treatment. It is thought that this result is related with the increase of fuzzes on the surface and shrinkage of the fabrics. Therefore, softening treatment did not have a positive effect on surface properties. However, for cotton fabrics, softening treatment was found to have a significant effect on kinetic friction coefficient. Treatment with softener 2 (macro siloxane), 
softener 3 (nano siloxane) and softener 4 (cationic), reduced the kinetic friction coefficient, which provides a smoother surface and a better frictional feeling.

\section{ACKNOWLEDGEMENT}

The authors give their special thanks to "Cotton Incorporated" for their financial support in supplying of cotton yarns and testing services.

\section{BIBLIOGRAPHY}

[1] Cook, J.G. Handbook of Textile Fibres, Vol.1: Natural Fibres, $5^{\text {th }}$ ed., Merrow Publishing, Shildon, England (1984).

[2] Carty, P. Fibre properties, $3^{\text {rd }}$ ed. Pentaxion Publishing, UK (1996).

[3] Miles, L. Focus on Cotton, Wayland Publishers Ltd, England (1986).

[4] Becerra, C.A.V. World cotton demand in the future: Issues on competitiveness, In: $25^{\text {th }}$ International Cotton Conference, Bremen, Germany, March 2 (2000).

[5] Shamey, R., Hussein, T. Critical solutions in the dyeing of cotton textile materials, In: Text Prog, 37, 1 (2005).

[6] http://www.ica-hk.org, (2014).

[7] Xu, Y., Lu, Z., Tang, R. Structure and thermal properties of bamboo viscose, tencel and conventional viscose fiber, In: J Therm Anal Calorim, 89, 197 (2007).

[8] Tausif, M., Ahmad, F., Hussain, U., Basit, A., Hussain, T. A comparative study of mechanical and comfort properties of bamboo viscose as an eco-friendly alternative to conventional cotton fibre in polyester blended knitted fabrics, In: J Clean Prod J, 89, 110 (2015).

[9] Lipp-Symonowicz, B., Sztajnowski, S., Wojciechowska, D. New commercial fibres called 'Bamboo Fibres' - Their structure and properties, In: Fibres \& Textiles in Eastern Europe, 19, 1 (2011).

[10] Waite, M. Sustainable textiles: The role of bamboo and a comparison of bamboo textile properties, In: JTATM, 6, 1 (2009).

[11] Schindler, W.D., Hauser, P. Chemical finishing of textiles, In: Woodhead Publishing Limited, The Textile Institute, Cambridge, England, pp. 29-42 (2004).

[12] Nostadt, K., Zyschka, R. Softeners in the Textile Finishing Industry, In: Colourage, 44, 53 (1997).

[13] Juodsnukytè, D., Gutauskas, M., Krauledas, S. Influence of fabric softeners on performance stability of the textile materials, In: Mater Sci+, 11, 179 (2005).

[14] Agarwal, G., Koehl, L., Perwuelz, A. The influence of constructional properties of knitted fabrics on cationic softener pick up and deposition uniformity, In: Text Res J, 80, 1432 (2010).

[15] Wahle, B., Falkowski, J. Softeners in textile processing Part I: An overview, In: Rev Prog Color, 32, 118 (2002).

[16] Philippe, F., Schacher, L., Adolphe, D.C., Dacremont, C. Tactile feeling: Sensory analysis applied to textile goods, In: Text Res J, 74, 1066 (2004).

[17] Manickam, M.M. Silicone chemistry for fabric care, In: Colourage, 56, 86 (2009).

[18] Case, F. Silicones in fabric care, In: Inform, 17, 559 (2006).

[19] Ushakova, V., Van Roy, B. External validation of silicone technologies for fabric care. In: Dow Corning Europe Publications, Printed in USA, Form No. 27-1114-01, (2003).

[20] Talebpour, F., Holme, I. Effects of silicone-based softener on the easy-care finished cotton fabric, In: Indian J Fibre Text, 31, 444 (2006).

[21] G. Agarwal, L. Koehl, A. Perwuelz, Sensory study of knitted fabrics that have gone through washing cycles with domestic softener. Part I: Establishment of a panel and assessment thereof, In: Fibres Text. East. Eur, 19, 100 (2011).

[22] E. Sarioğlu, N. Çelik, Investigation on regenerated cellulosic knitted fabric performance by using silicone softeners with different particle sizes, In: Fibres Text. East. Eur, 23, 71 (2015).

[23] Lima, M., da Silva, L.F., Vasconcelos, R., Cunha, J., Frıctorq, Desıgn for the objectıve measurement of frictıon in 2D soft surfaces, In: XIII Congreso Internacional de Ingeniería de Proyectos Badajoz, 8-10 de Julio de 2009.

[24] BS EN ISO Standard, Standard Number: 9073-9, 2008.

[25] Saville, B.P. Physical testing of textiles, In: Woodhead Publishing Ltd, Cambridge England, ISBN 0849305683 , p. 310 (1999).

Authors:
GAMZE SÜPÜREN MENGÜÇ${ }^{1}$, EYLEN SEMA DALBAŞI², ARIF TANER ÖZGÜNEY²,
NILGÜN ÖZDIL ${ }^{2}$
${ }^{1}$ Ege University, Emel Akın Vocational Training School, 35040, Ege University, Bornova/lzmir
2Ege University, Faculty of Engineering, Department of Textile Engineering, 35040, Ege University, Bornova/lzmir
Corresponding author:
Prof. Dr. NILGÜN ÖZDIL
e-mail: nilgun.ozdil@ege.edu.tr




\title{
A Romanian case study of clothes and accessories upcycling
}

\author{
DOI: $10.35530 / I T .070 .03 .1544$
}

\section{REZUMAT - ABSTRACT}

\section{Un studiu de caz din România privind valorificarea îmbrăcămintei și a accesoriilor}

Lucrarea de față urmărește să investigheze practica valorificării și reproiectării. Studiul se bazează pe multiplele organizații implicate în activitățile de reproiectare. Organizațiile selectate pentru studiu sunt situate în partea de nord a României. Interviurile semi-structurate, împreună cu observațiile directe, au fost folosite pentru a colecta informații. Lucrarea oferă informatiii practice privind procesul de valorificare. Diferite tipuri de produse reproiectate sunt realizate din deșeuri industriale și de consum, cum ar fi îmbrăcămintea reproiectată, accesoriile pentru femei, gențile, poșetele pentru femei și articolele de papetărie de birou. Valorificarea este considerată, în general, nefezabilă din punct de vedere economic. Cu toate acestea, acest studiu a găsit rezultate contradictorii. Activitățile de reproiectare bazate pe cerere pot ajuta o organizație să obțină profit. Două dintre cele trei organizații selectate sunt capabile să se autosusțină. Una dintre organizații este recent intrată pe piețele românești de îmbrăcăminte și este capabilă să concureze cu jucătorii existenți. Acest studiu ar putea fi văzut ca una dintre primele încercări de a explora empiric practica valorificării textilelor și a accesoriilor în Europa de Est. Constatările din studiul de caz actual pot oferi mai multe informații utile pentru alte companii similare pentru a face activitățile de reproiectare profitabile.

Cuvinte-cheie: valorificare, reproiectare, îmbrăcăminte, piele, accesorii

\section{A Romanian case study of clothes and accessories upcycling}

The present paper aims to investigate the practice of upcycling and redesign. The study draws on the multiple organizations involved in the redesigning activities. The organizations selected for the study are located in the northern part of Romania. Semi-structured interviews along with direct observations were used to collect information. The paper provides practical insights to upcycling process. Various kinds of redesigned products are made out of consumer and industrial wastes such as redesigned clothes, accessories for ladies, handbags, ladies purses and office stationery. Upcycling is generally considered as economically non-feasible. However, this study has found contradictory results. The demand-based redesign activities can help an organization to earn a profit. Two out of three selected organizations are able to self-sustain. One of the organizations is newly entered into the Romanian used clothing markets and ables to compete with existing players. This study could be seen as one of the early attempts to empirically explore the practice of textile and accessories upcycling practice in Eastern Europe. The findings from the current case study can provide several useful insights for other similar companies to make redesign activities profitable.

Keywords: upcycling, redesign, clothes, leather, accessories

\section{INTRODUCTION}

"Upcycling" is an improved and viable way to reuse, in which a product can be used after significant modification [1]. In the present situation, used clothes are reused only for their basic functions as well as for several inferior purposes. In case of inferior usage, the products are not used to its full capacity. Therefore up-cycling can be considered as of the best alternatives over direct reuse and recycling. This is mainly because products are used for the improved purpose, hence higher values can be derived from the existing resources [1]. One successful attempt has been done to maximize the use of resources by firm 'aWEARness'. The company has developed polymer fibres which are long-lasting. Accessibility Based Business Model is developed for the sale of the products. In this business model, the customers do not own the product and ownership lies with the company. The user avails service of the product and then returns back to the company. The company redesign/up-cycle or recycles the product according to the condition [2]. Recycle may be considered as the most conventional process to close the loop. In this process, the raw material is recovered after processing for its properties or characteristics. For example, fire retardant non-woven material recovered can be used in a mattress spring cover [3]. Recycling process can be divided into up-cycling and down-cycling. In up-cycling, value/quality of the product is improved by making a superior product. In down-cycling, an inferior product is made out of raw material. Beside this, reuse of clothes may significantly contribute in reducing the environmental hazard due to the restricted entry of new clothes in the value chain [4-5]. Reverse logistics of clothes for reuse purpose can save energy by $97-98 \%$ in comparison to manufacture same clothes from fibers [6]. The figures illustrate that asup-cycling is better than down-cycling. 
Redesign or upcycling is a way to improve the chance of reuse. Reuse plays a pivotal role to control the environmental degradation by saving natural resources for the future use and reducing pollution. The process of redesigning mainly consists of three steps i.e. ideation, reconstruction and fitting [7]. There are several factors such as material durability, deconstruction efforts and price of redesigned products that can influence the process of redesign. Durable clothing products such as denim jeans are most preferred items for redesign [8]. Paras, Ekwall have found that in the absence of redesign mechanism, even good condition products are incinerated. Incineration and upcycling are two different corners for a product in the term of its use [9]. The upcycling process is economically less feasible due to high labour cost in Western Europe. The current case study can be considered as an instrument to understand how to make redesign process profitable. In the next sections, the methodology will be presented followed by discussion and conclusion.

\section{METHODOLOGY}

An explorative study was conducted to identify the existing practices of up-cycling. Multiple sites were studied which enhanced the robustness of the study [10]. We have chosen the organizations located in lasi, Romania. The data was collected with the help of semi-structured interviews with the founder and senior manager of the organization. The collected data were analysed using a thematic approach. For the present study, three organizations were selected. These are referred as $A, B$, and $C$ to maintain secrecy. $A$ and $C$ are independent social organizations while $B$ is associated to an international charity organization. Table 1 summarises the details of the methodology adopted:

In total, seven interviews were taken at interviewee's office location. The interviews were kept short which lasts for about an hour. These were conducted within a span of one year and six month period i.e., from April 2016 to September 2017. The interviews were conducted with open-ended questions; therefore a protocol has been set to increase the reliability of the information. Different documents along with direct observation technique also helped to get useful infor- mation. NVivo 10 was used to analyse the interviews and other collected information. Interviews transcripts were systematically analysed to find out themes, ideas, patterns, concepts to test deductive framework. Information pertaining to each of the companies was first analyzed individually. Based on the responses, the questionnaires were redefined before moving to the field. During analysis, each of the interviews was compared to previous one to find new formation [11]. Hence, there was a constant backward and forward movement to find new empirical patterns from the case study. On the basis of cross-case analysis, the theoretical saturation was achieved and a model for redesign or upcycling practice is proposed based on the insights [12].

\section{FINDINGS}

This section will provide a practical instance to upcycling practice. Qualitative insights were gained by understanding and analysing the status quo of upcycling practice at three organizations. The organizations chosen for the current case study are specialised in different kind of products, for example, Case A (clothes and accessories), Case B (clothes and leather accessories) and Case C (accessories and stationeries).

\section{Case A: a case of clothes and accessories up-cycling}

Organization A is a Romanian based redesign organization located in the northern part of the country. The organization $A$ is under the umbrella of a 7-yearold social organization that aims to protect the environment. The organization vision is to promote circular economy by minimisation of waste through collection and conversion of discarded textiles to a usable product. The positive impact on the environment is created by redefining clothes, extending the lifespan of textile and creation of new products. The customised products are created by using textiles collected from local people in the bins, along with workshop and factory leftovers. The figure 1 depicts a few illustrations of redesigned clothes and accessories at organization $A$.

The organization $A$ is found to be one of most the successful and economically sustainable organization.

\begin{tabular}{|c|c|c|c|}
\hline \multicolumn{4}{|c|}{ METHODOLOGY USED FOR THE CASE STUDY } \\
\hline Case & $\begin{array}{l}\text { Number of visits } \\
\text { (Direct observation) }\end{array}$ & $\begin{array}{c}\text { Interviews } \\
\text { (Individual face to face) }\end{array}$ & Documents \\
\hline \multirow{3}{*}{ A } & \multirow{3}{*}{06} & Founder & \multirow{3}{*}{ Patterns, work plan, products design etc. } \\
\hline & & Manager & \\
\hline & & Designer & \\
\hline \multirow{3}{*}{ B } & \multirow{3}{*}{$\begin{array}{l}02 \text { (1 visit to the factory at } \\
\text { Ploesti and } 1 \text { visit to } \\
\text { redesign workshop at lasi) }\end{array}$} & Country manager & \multirow{3}{*}{$\begin{array}{l}\text { Inventory records, production planning charts, } \\
\text { products design etc. }\end{array}$} \\
\hline & & Factory manager & \\
\hline & & Redesign manager & \\
\hline C & 01 & Founder & Stationary and accessories pattern, product design etc. \\
\hline
\end{tabular}




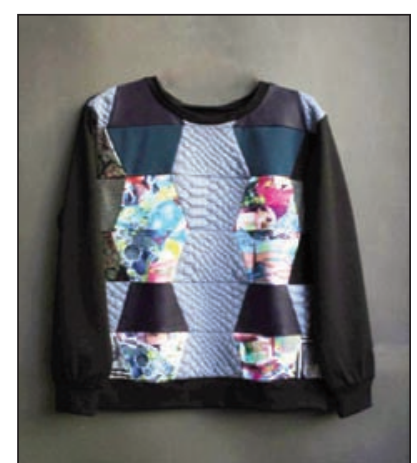

Sweatshirts

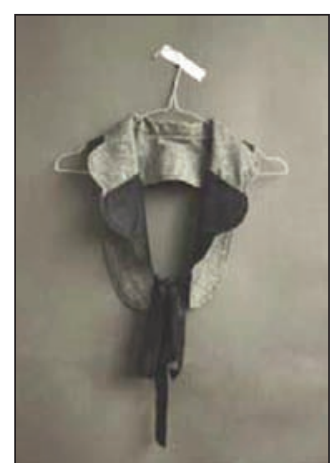

Accessories

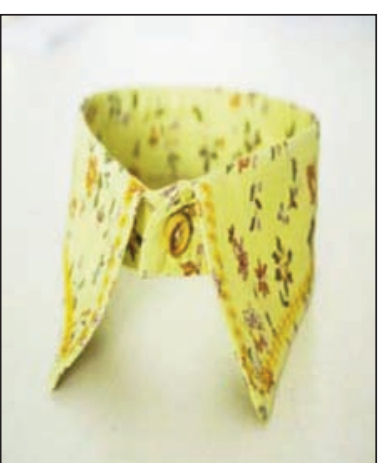

Accessories

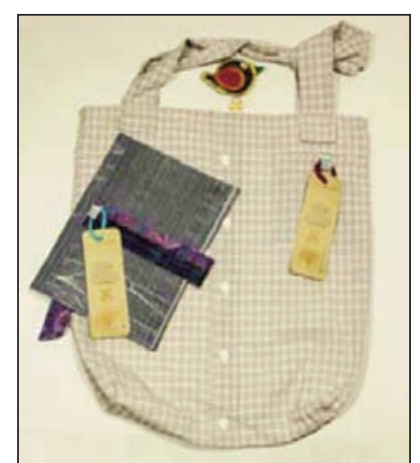

Bag and pouch

Fig. 1. Up-cycled products of organization C (Source: Organization social media websites)

There are five full-time employees involved in the redesign process. The organization works like any other professional organization. The organization participates in different kinds of street festivals to showcase and sell up-cycled products. In order to create awareness about redesign and reuse of textile-based products the organizations A also organise design workshops at regular intervals. The organization has installed 1-2 collection bins near some private shops even though there is no provision of textile collection bins by the municipality. The designers, managers and founder of the organization $A$ keep themselves updated about the latest redesign trends and policies. Recently organization A has collaborated with the Shop of Organization B to get unsold jeans for the redesigning purpose. The organization A has also tied up with the solid waste collector to collect unused and waste textile for the recycling (mainly mechanical).

\section{Case B: a case of clothes and leather accessories up-cycling}

Organization B is a sister company of multinational charity organization. The head office of the company is located in the Bucharest and warehouse is in Ploesti. The organization has two redesign workshops, one is located in the Ploesti and other is located in lasi. The main goal of the organization is to improve the employability and life of Roma people. Various charities and social welfare projects are undertaken to achieve this goal. The finance for the project is earned by the organization from the sale of second hand clothes. Redesign clothes and accessories are exported back to Norway for sales. Some of the up-cycled products from organization $B$ are shown in the below figure 2 .

Organization B is mainly entered into Romanian markets for providing job and training for the Roma (Gypsies), disabled and drug addicted people. The main work of organization B is to import used clothes from Norway and distribute it to the company owned shops after sorting. However, the organization has small facilities for up-cycling clothes for the training purpose. The up-cycling of leather is done at the professional level in the organization B. The leather jackets, trousers and other clothing material found during

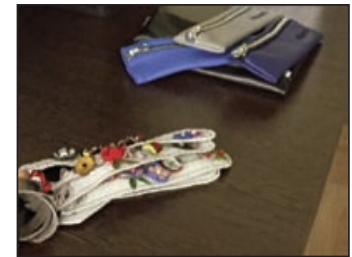

Ladies wallet and bracelets

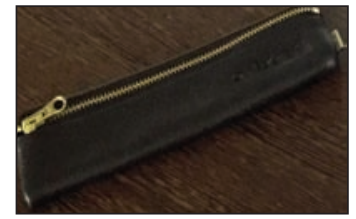

Pencil pouch

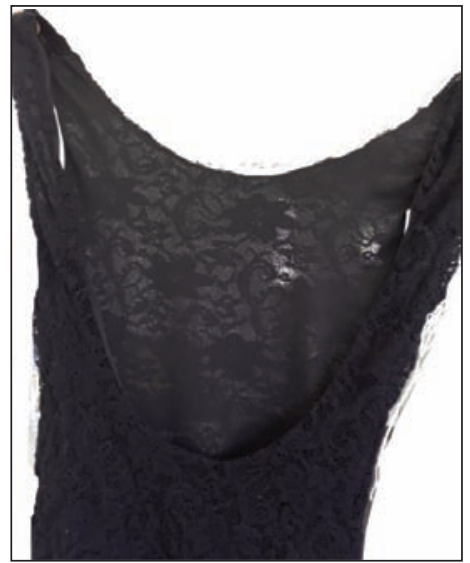

Redesigned dress
Fig. 2. Up-cycled products of organization C

sorting processes are handed over to the redesign team. The redesign team extracted and cut the useful part with the help of cutting machines. Besides this, the redesign team also receive industrial leftover and waste from shoes making companies. Useful leather parts are extracted in the rectangular from the waste and used for making pencil pouch, ladies' wallets, gents' wallets and bracelets. Most of these products are exported to Norway for sale. Some time organization $B$ also receives a unique order like making a net bag to clean football players' clothes in the washing machines.

\section{Case C: a case of accessories and stationeries up-cycling}

This is also a Romania based redesign organization registered as a social organization. Organization C has started its operations in the year 2012 in lasi, a city in the northern part of Romania. The founder of the organization got inspiration from the redesigning/up-cycling, while she was on an internship in an Indian charitable organization. Based on the inspiration, the founder of the organization has started this organization to completely give new shape to the existing waste or discarded materials. The aim of the organization is to convert useless and discarded items into valuable products. Street banners, scrapped fabrics and old trucks covered into bags, wallets, paper folders and others accessories and 


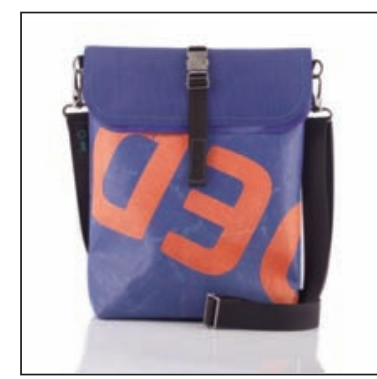

Bag

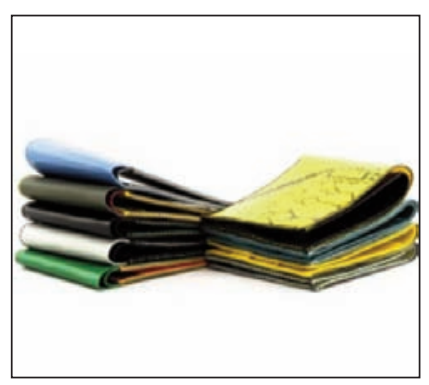

Wallets

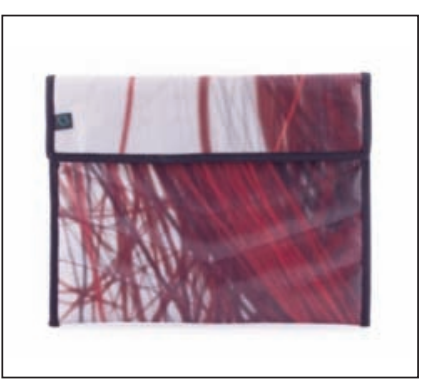

Folders

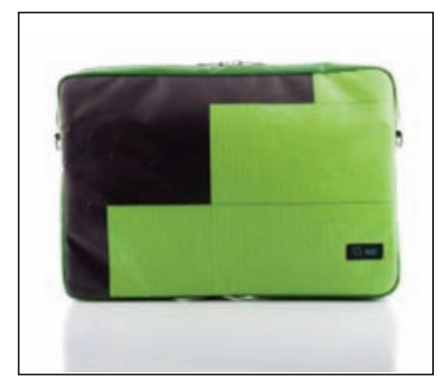

Laptop pouch

Fig. 3. Up-cycled products of organization C (Source: organization website)

stationeries items. Organization $\mathrm{C}$ has contracted with advertising and logistics companies to receive discarded banners and truck covers. Figure 3 depicts some the up-cycled products of the organization C. Organization $\mathrm{C}$ has focused on the banner and truck cover based accessories and stationeries. The organization has collaborated with multiple advertising agencies to receive old banners. Most of the advertising companies are located in the capital city of Romania i.e., Bucharest. Hence, the organization C needs to pay transportation cost to get banners and truck covers in lasi. Organization $\mathrm{C}$ has two employees to cut, sew and pack the accessories and orders. There is no shop owned by company and therefore, the company has collaborated with a few shops located in the different cities of Romania. The shop owners receive a fixed amount of commission for display and sale of the products. The organization also use e-commerce platform for the sale of up-cycled products. Besides the retail sales, the organization also receives bulk orders from the company for the events such as conference, training etc. Similar to the organization $\mathrm{A}$, the organization $\mathrm{C}$ also participate in the various street market to show their presence and sale the products.

Table 2 presents the summary of the existing practices of making clothes, accessories, and stationeries

\begin{tabular}{|c|c|c|c|}
\hline \multicolumn{4}{|c|}{ STATUS QUO OF UP-CYCLING PRACTICE IN THE SELECTED ORGANIZATION } \\
\hline & Organization A & Organization B & Organization C \\
\hline Type & Non profit, Individual & Non profit, Multinational & Non profit, Individual \\
\hline $\begin{array}{l}\text { Government } \\
\text { support }\end{array}$ & Received Norwegian grants & $\begin{array}{l}\text { Receiving all financial } \\
\text { support from the } \\
\text { multinational company }\end{array}$ & Winner of European startup prize \\
\hline $\begin{array}{l}\text { Collection } \\
\text { methods }\end{array}$ & $\begin{array}{l}\text { 1. On Call for bulk collection } \\
\text { 2. Direct handover in } \\
\text { shop/warehouse } \\
\text { 3. Factory leftover } \\
\text { 4. Collection bins at a private place } \\
\text { 5. Unsold items collected from a } \\
\text { second-hand clothes store }\end{array}$ & $\begin{array}{l}\text { 1. Donation from Norwegian } \\
\text { organization. } \\
\text { 2. Factory left over } \\
\text { 3. Collection bins (currently } \\
\text { in process of permission) }\end{array}$ & $\begin{array}{l}\text { 1. Direct handover } \\
\text { 2. Agreement with advertising } \\
\text { and transport companies }\end{array}$ \\
\hline $\begin{array}{l}\text { Redesigned } \\
\text { facilities }\end{array}$ & $\begin{array}{l}\text { Equipped with basic machines } \\
\text { required for a redesign, such as: } \\
\text { 1. Sewing machines } \\
\text { 2. Block printing machines } \\
\text { 3. Single head embroidery } \\
\quad \text { machines } \\
\text { 4. Ironing, cutting table }\end{array}$ & $\begin{array}{l}\text { Equipped with modern } \\
\text { facilities required for a } \\
\text { leather redesign, such as: } \\
\text { 1. Sewing machines } \\
\text { 2. Leather cutting machines } \\
\text { 3. Leather pressing } \\
\quad \text { machines }\end{array}$ & $\begin{array}{l}\text { Equipped with basic machines } \\
\text { required for a redesign, such as: } \\
\text { 1. Sewing machines } \\
\text { 2. Cutting tables } \\
\text { Note: Printing operations are } \\
\text { outsourced tothe currently } \\
\text { in-house facility is not available. }\end{array}$ \\
\hline Sale & $\begin{array}{l}\text { 1. Sales in own shop } \\
\text { 2. Online sale through own } \\
\text { e-commerce websites } \\
\text { 3. Products are displayed and sold } \\
\text { in sister organizations cafeteria } \\
\text { 4. On order manufacturing and } \\
\text { sales }\end{array}$ & $\begin{array}{l}\text { 1. Most of the redesigned } \\
\text { accessories are exported } \\
\text { to Norway } \\
\text { 2. Sometimes products are } \\
\text { also displayed in the } \\
\text { organization owned a } \\
\text { second-hand shop }\end{array}$ & $\begin{array}{l}\text { 1. Company-owned e-commerce } \\
\text { websites } \\
\text { 2. Agreement with shops in 3-4 } \\
\text { cities. Organization C } \\
\text { accessories and stationeries } \\
\text { are displayed and sold on a } \\
\text { commission basis. } \\
\text { 3. On order manufacturing and } \\
\text { sales }\end{array}$ \\
\hline
\end{tabular}


out of discarded used products. The interviews indicated that all the three companies have different methods to perform redesign activities. $A$ and $C$ are individual charitable social organizations working independently. While organization B is sister organization of a Norwegian multinational charity organization that are further taking support from their allied organizations to sale up-cycled products. Up-cycling and redesigning activities are not main focus as organization $B$ is a member of a multinational charity organization and has financial support from the parent organization. The main focus of the organization is to engage disabled and alcoholic people whereas for organization A and C, up-cycling is a profession to self-sustain and support day to day activities.

\section{DISCUSSION AND CONCLUSION}

The process of redesign varies from one organization to other organization. Organization A believes in the demand-based redesign. The founder and manager of the organization shared that there is no point in producing anything that cannot be sold. Hence, the organization emphasise on first receiving orders and accordingly producing redesign products for the customers. However, some of the products that have regular demand are also produced based on the expected demand which is estimated based on the experience of the founding members. Organization B remakes new product from industrial and consumer discards based on the requirements of the sister concerned located in Norway. However, some of the products are also reshaped or redesign for the local shops. Overall, organization B performs two kinds of redesign practices, one is demand-based and other is product based. Organization $\mathrm{C}$ is making products from old advertisements banners and truck covers. The discarded materials are transported by the advertising or transport companies to Organization $\mathrm{C}$ and the company is responsible for the payment of the transportation cost. The dirty materials are cleaned and stored for the future use as per demand. Organization $\mathrm{C}$ mostly do redesigning based on the order received from banks, institutes, information technology companies etc. However, organization C also keeps on making some standard products such as bags, pouch, wallets etc. Among all the organizations, the demand based upcycling is found to be a common approach. Demand-based redesign approach found to be highly sustainable because only those items are produced that are required in the market which results in saving the manpower, money and efforts. Organization $A$ redesigns based on the demand of the product. This enables the organization to sustain financially and get fair returns. Advertising through social media is done to create the demand for newly redesigned clothes and accessories. Organization B produces items for the order received from sister organizations from Norway. Organization C works on corporate orders and regular requirements of an online shop and normal shops.

The investigation of upcycling practice revealed that there aredifferent approaches to carry out upcycling practice. An upcycling process consists of ideation, reconstruction and fitting stages. Inferior fabric quality and fast fashion can be considered as main barriers for upcycling. The 'product based redesign' and 'demand-based redesign' are some of the strategies that can boost upcycling. Variations in size, colour and pattern pose another set of problems. Solution to these problems can be achieved through skill enhancement programmes and innovation. Along with a set of skill, the person involved in the redesign process should have the desire and ready to devote time to it. Retaining provenance and narrative increase chance of clothes purchase. Upcycling operation is still at its nascent stage which leads to high cost of operation. Support of government and volunteers can make redesigning process cost-effective and successful. Upcycling has various benefits which include environmental benefits and monetary benefits for the individuals. In future, the current study can be extended by the mathematical formulation of the upcycling and redesigning process by applying different techniques such as genetic algorithm, artificial intelligence and other simulation techniques. A quantitative study such as model development can also provide a good avenue to extend the work. Future scholars can further study the role of price, design and consumer attitude along with the quality of clothing on the value chain. Validation of current finding in different geographical context can provide useful insights.

\section{ACKNOWLEDGEMENT}

This work is conducted at "Gheorghe Asachi" Technical University of lasi, Romania under SMDTexproject. We would like to acknowledge the financial support provided by EU.

\section{BIBLIOGRAPHY}

[1] Cuc, S. and Tripa, S. Redesign and upcycling-a solution for the competitiveness of small and medium-sized enterprises in the clothing industry. In: Industria Textila, 2018. 69(1), pp. 31-36.

[2] Dervojeda, K., Verzijl, D. and Rouwmaat, E. EU-circular-supply-chains..In: Business Innovation Observatory, 2014.

[3] Morley, N.J., Bartlett, C. and McGill, I. Maximising reuse and recycling of UK Clothing and Textiles. A research report completed for the Department for Environment, Food and Rural Affairs. In: Quality, 2009, p. 10.

[4] Farrant, L., Olsen, S.I. and Wangel, A. Environmental benefits from reusing clothes. In: International Journal of Life Cycle Assessment, 2010, 15, pp. 726-736. 
[5] Tipper, M.J., et al. Principles of the recovery and reuse of corporate clothing. In: Proceedings of the ICE - Waste and Resource Management, 2010, 163 (November), p. 165-172.

[6] Woolridge, A.C., et al. Life cycle assessment for reuse/recycling of donated waste textiles compared to use of virgin material: An UK energy saving perspective. In: Resources Conservation and Recycling, 2006, 46(1), pp. 94-103.

[7] Paras, M.K. and Curteza, A. Revisiting upcycling phenomena: a concept in clothing industry. In: Research Journal of Textile and Apparel, 2018, 22(1), pp. 46-58.

[8] Paras, M.K., Pal, R. and Ekwall, D. Systematic literature review to develop a conceptual framework for a reusebased clothing value chain. In: The International Review of Retail, Distribution and Consumer Research, 2017, pp. 1-28.

[9] Paras, M.K., et al. An exploratory study of Swedish Charities to develop a model for the reuse-based clothing value chain. In: Sustainability, 2018, 10(4), p. 1176.

[10] Herriott, R.E. and Firestone, W.A. Multisite qualitative policy research: Optimizing description and generalizability. In: Educational Researcher, 1983, 12(2), pp. 14-19.

[11] Czarniawska, B., Social science research: From field to desk, 2014, SAGE Publications.

[12] Bryman, A. and Bell, E. Business research methods, 2015, Oxford University Press.

\section{Authors:}

\section{MANOJ KUMAR PARAS ${ }^{1,2,3}$ \\ ANTONELA CURTEZA ${ }^{2}$ \\ RUDRAJEET PAL ${ }^{3}$ \\ YAN CHEN ${ }^{1}$ \\ LICHUAN WANG $^{1}$}

${ }^{1}$ College of Textile and Clothing Engineering, Soochow University,

Suzhou 215006, China

2"Gheorghe Asachi” Technical University of lasi,

Bulevardul Profesor Dimitrie Mangeron 67, Iasi, 700050, Romania

${ }^{3}$ Faculty of Textiles, Engineering and Business, University of Borås, Allégatan 1, 50139032 Borås, Sweden

\section{Corresponding author:}

\section{LICHUAN WANG}

e-mail: Lcwang@suda.edu.cn

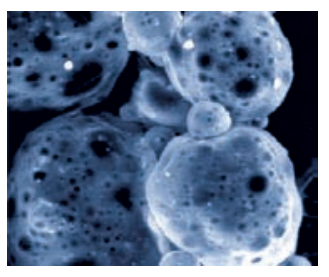




\title{
The impact of foreign exchange movements on Turkish textile sector
}

\author{
DOI: 10.35530/IT.070.03.1591
}

\section{REZUMAT - ABSTRACT}

\section{Impactul mișcărilor de schimb valutar asupra sectorului textil din Turcia}

Datorită importanței lanțului de aprovizionare global și a exporturilor de înaltă tehnologie, importanța noilor piețe în dezvoltare crește treptat. Turcia păstrează poziția strategică pentru sectorul textil, fiind situată în punctul central dintre Balcani, Asia, Orientul Mijlociu, Africa de Nord, Europa de Est și Rusia. Poziția geografică care permite un comerț mult mai avantajos în regiune face ca țara să fie mult mai competitivă decât concurenții săi. Cu toate acestea, devalorizarea și volatilitatea lirei turcești în 2018 au afectat grav sectorul textil din Turcia. Acest studiu urmărește să determine impactul fluctuațiilor cursului de schimb asupra performanțelor firmelor din industria textilă din Turcia între anii 2013 și 2017 . În plus, a fost efectuată o analiză de regresie multiplă pentru a investiga impactul vechimii și mărimii firmei asupra performanței acesteia. Potrivit rezultatelor, volatilitatea cursului de schimb și dimensiunea firmelor au avut un efect negativ asupra performanței firmelor, în timp ce vechimea firmei nu a avut nicio influență semnificativă asupra acestui indicator.

Cuvinte-cheie: schimb valutar, firme din industria textilă, sectorul textil din Turcia, performanța firmelor, valoarea firmelor

\section{The impact of foreign exchange movements on Turkish textile sector}

Due to importance of global supply chain and high-tech exports, importance of new developing markets is gradually increasing. Turkey keeps the strategic importance for textile sector being in the center of Balkans, Asia, Middle East, North Africa, Eastern Europe and Russia. The geographical location allowing trade in the region makes the country much more advantageous than its competitors. However, devaluation and the exchange rate volatility of Turkish Lira in 2018 have been seriously affecting Turkish textile sector. This study aims to determine the impact of exchange rate fluctuation on Turkish textile firms' performance between the years of 2013 and 2017. Additionally, multiple regression analysis was done in order to investigate the impact of firms' performance such as firm age and firm size on performance of the textile firms. According to results, it was observed that exchange rate volatility had a negative effect on the firm performance and the firm size had a negative effect on firm performance while the firm age did not have any influence on firms' performance significantly.

Keywords: exchange rate, textile firms, Turkish textile sector, firm performance, firm value

\section{INTRODUCTION}

Textiles and clothing have been the major products for industrializing countries which played a critical role in Britain, North America, Japan and Turkey for the last two decades. Before the World War II, Western Europe countries and the US controlled the world economy as well as the industrial production. Afterwards, less developed countries took the control of production and providing the raw materials. Industrial textile production totally moved to Japan after 1940's when she became the leader of economic development in the region of Asian. Later on high production costs had compelled for the new investments in other Asian countries such as Japan, Hong Kong, South Korea and Taiwan. During the same period, textile industries in Europe (Germany, Italy, England, France) began to produce at large capacities with the imported yarns provided from the nearest countries such as Turkey. Turkish textile industry has begun its spreading across the country with the foundation of Turkish Republic in 1923. The big state enterprise "Sümerbank" encouraged for sector with the initial developments on textile and apparel sector until it was privatized. The new investments in textile and apparel sector launched after the second half of 1995 when the quantitative restrictions in textile trade between Europe and Turkey were totally eliminated. Turkish textile companies and exporters maintain their presence in the most foreign markets of Europe [1-2]. The geographical location allowing trade in the region makes the country much more advantageous than its competitors. She has the dynamism for taking part in the new growing markets as a result of globalization [3]. The profitability of the markets in the country has improved a lot owing to concentrating on marketing and distribution. It was thought that Turkish Lira depreciation in 2018 and response of Turkish textile sector which is very important among Europe and World textile industry should be evaluated for the possible effects of exchange rate fluctuations on Turkish firms.

\section{FOREIGN EXCHANGE RISK IN TURKISH TEXTILE SECTOR}

\section{Importance of textile on Turkish economy}

There has been an appreciable effect of Turkish textile and clothing sector on Turkey's development and growth for the last 30 years. It is known that sector 
has greatly developed since 1980 when the country put liberal economic policies into operation providing it reaching to foreign markets. Cotton has always become important to the industrial sector of textile as well as to the internal and external trade of Turkey. Turkey has the $8^{\text {th }}$ place after India, China, USA, Pakistan, Brazil, Australia and Uzbekistan among the main cotton fiber growing countries in the world. However, significant drops in the domestic production resulted with the requirement of cotton imports of considerable magnitude, making the country "the fifth largest importer of cotton after Bangladesh, Vietnam, China and Indonesia" in 2016/2017 season according to ICAC estimates [4-6]. Turkey gets the benefits of having the highest fibre and yarn production capacity in Europe. Although China has appeared as a new player for European companies, the certain skills such as flexibility could not meet the European customers who are difficult to be satisfied in terms of response speed, quality and innovation [7]. Textile export which is 16 percent (\%) of total export of the country in 2017 has a prominent influence on Turkish economy. There are about 53,000 operating companies in the sector. Exports of ready to wear items \$17 billion and textiles were \$8 billion in 2017. European countries prefer Turkish textile and garment exporters since those companies work with lowstocks and short response time as well as with high quality. Additionally, low labour wages can be considered as another factor. Germany, Spain, England, Holland and French, Italy, USA, Poland and Denmark are the main exporters of Turkey. According to Turkish Statistical Institute sources under the title of Turkey's foreign trade; Country exports have increased 5.1 times for the last 15 years while the imports have increased 3.6 times during the same period. Table 1 reveals a breakdown of textiles and clothing exports which include cotton exports, together with the share of textiles and clothing exports in the overall exports in Turkey. As it is observed, there is a high contribution of "textiles and clothing" exports to the overall exports of the country. In 1990's, the share of textile and apparel were $30 \%$ of total exports and it gradually decreased to $20 \%$ levels because of the increased share of exports from other sectors such as marble, various industrial minerals, agricultural products and other food products [8].
Over the years, the increase in textile and apparel exports from Turkey has not only provided a growth in industrial exports but also led a reduction in the current trade deficit of Turkey (according to Turkish ministry report 2018; the exporting amount in 2017 was approximately 17 billion Euro whereas the importing amount was approximately 9 billion Euro in Turkish textile). In July 2013, Turkish government emphasized a strong support again for textile industry when the tenth five-year development plan covering the 2014-2018 period which was approved in the Grand National Assembly of Turkey in July 2013. New marketing and production channels have been created. Intelligent and functional textiles have been focused on a lot which are thought to be leading a great impact for Turkish economy. Owing to high value added of the technical textile products and their less vulnerability to price changes, many of the Turkish companies have started technical textile as well as nonwoven production [8].

\section{Exchange rate movements and possible effects on Turkish textile sector}

Owing to the globalization of business environment over the last decade, there is almost no pure domestic company left. Today, foreign exchange risk influences all international trade companies. There are many ways through which the exchange rate movements could affect the firm performance. Cost of imported inputs relative to production factors, export prices, foreign competitors external borrowing costs can be ordered respectively. Generally, an export-oriented firm gets benefit from the depreciation of the local currency whereas import-oriented firms suffer from this situation, which result with increased cost of production and low profits. The impact on firm performance is one of the main component which determines how exchange rate influences total economic growth. Exchange rate fluctuations have vital effect on the companies' profitability. The prices may change due to movements in the exchange rate which will result with the change of competition with domestic exporters and importers. Since the input prices increase for the industries using internationally priced raw materials, total asset of the firms may also change critically in terms of foreign currencies. When considering many industrial organizations in the

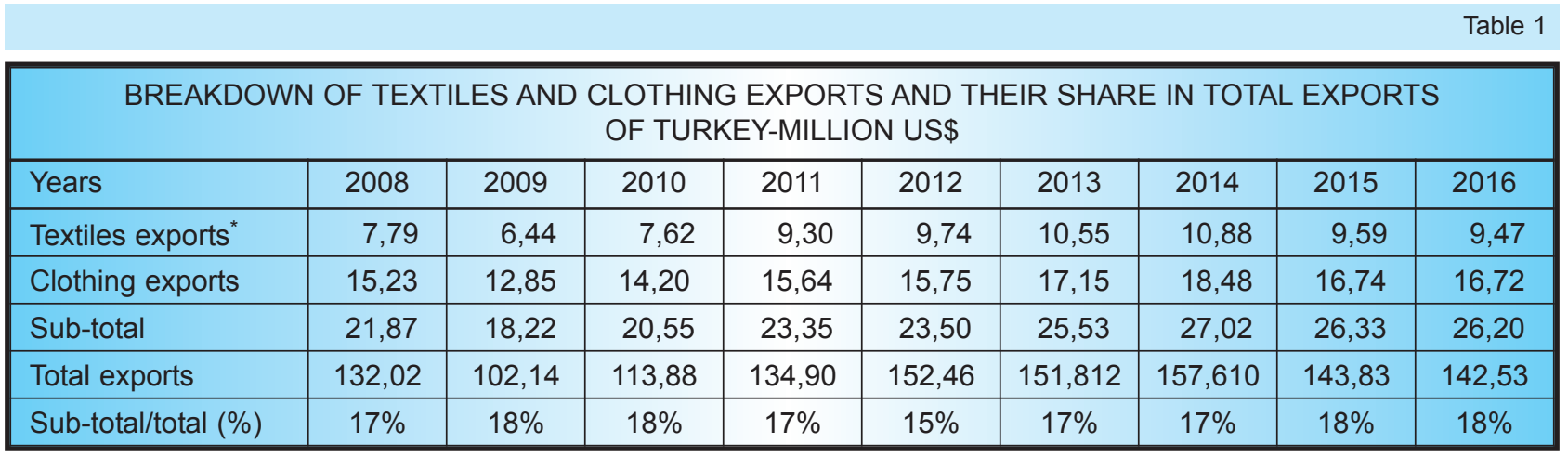

* includes cotton exports; Source: Turkish Statistical Institute (TurkStat). 

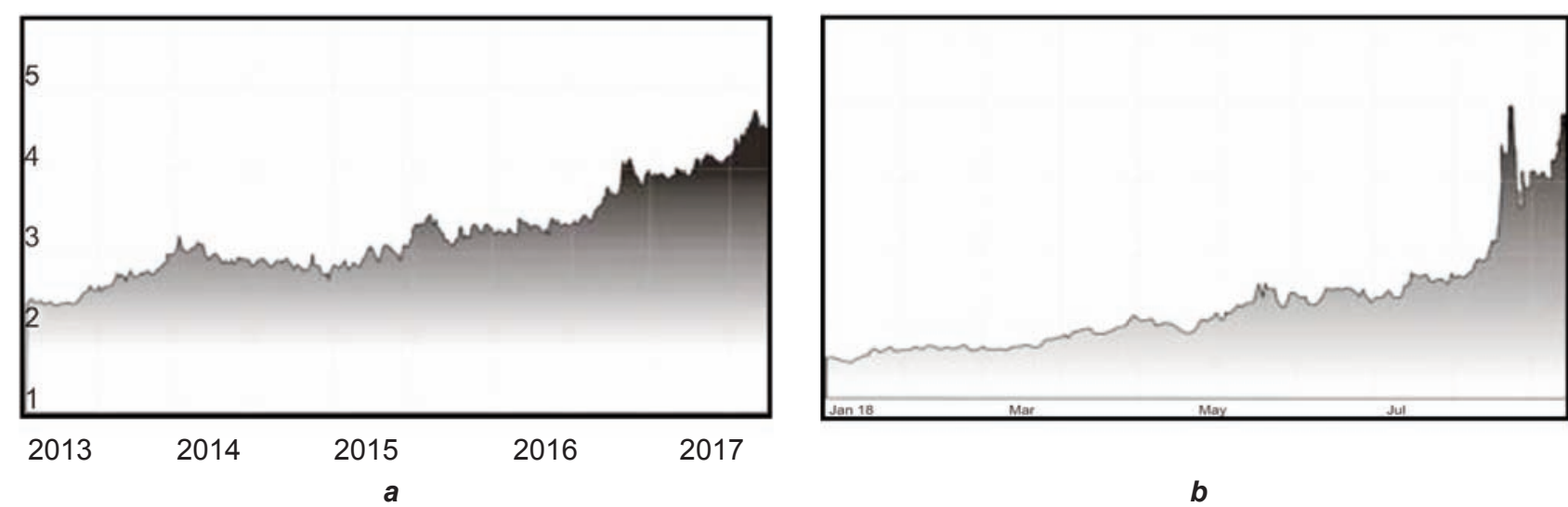

Fig. 1. a - Euro to Turkish Lira Chart (31.12.2013 - 31.12.2017);

$b$ - Euro to Turkish Lira Chart (1 Jan 2018 - 29 June 2018)

country are thought to be in the same position, the country's economic relations in the world are expected to change as well [9]. Most of the studies related to exchange rate fluctuation supports the idea that movement of currency may lead to statistically significant profitability, growth, investment as well as to some trade decreasing effects [10-11]. Previous studies from developed markets indicated some conflicting results with regard to exchange rate risk on firm valuation; Jorion, Amihud, Bortoy and Bodnar concluded that there were no significant correlations between stock prices and exchange rate exposure in USA firms [12-14]. On the other hand, Bodnar and Gentry and Choi and Prasad found that exchange rate movements significantly affected the firm value and company income. Additionally, $\mathrm{He}$ and $\mathrm{Ng}$, Doukas et al., Nydahl declared in their studies that values of Japanese and Swedish firms were significantly were significantly influenced by the exchange rate fluctuations [15-18]. Khoo and Chamberlain et al. studied the values of returns of Australian mining firms and Japanese banking firms were weakly influenced by the exchange rates [19-20]. Kıymaz found that Turkish textile companies were highly exposed to foreign exchange risks and the degree of exposure were generally for textile machineries, chemicals used in treatment processes [21].

Turkish lira (€) has depreciated against Euro $(€)$ for the last 5 years (figure 1, a). 1 Euro was 2.93 Turkish lira in 31.12.2013 whereas it was 4.52 Turkish lira in 31.12 .2017 . The depreciation was around $54 \%$ in 5 years. Figure $1, b$ reveals the value change of Turkish lira against Euro between the dates of 01.01.2018 and 31.08.2018. For the last 8 months, Turkish lira has depreciated from 4.52 to 7.65 against Euro which indicated a depreciation of almost $\% 70$ for Turkish lira only in 8 months. This situation is expected to result with a high risk for the companies. In the last 5 years, the fluctuation of the Turkish lira has increased sharply especially in 2017 and 2018. Turkish lira ( has been seriously depreciated against Euro $(€)$ and the Dollar (\$). The excessive increase and volatility in the exchange rates have caused the attention to focus on foreign exchange debt and foreign exchange position of the real sector. It is recently
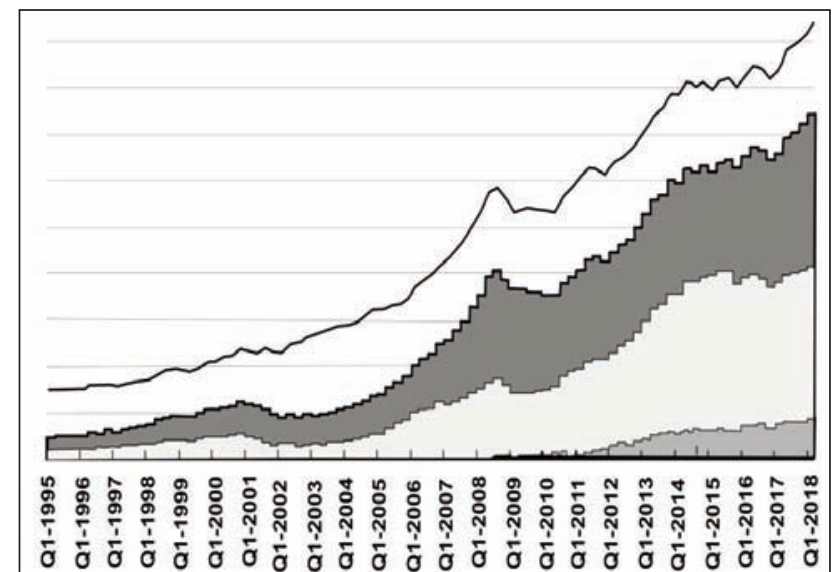

-State Banks $\quad$ Private Banks and Other Financial Institutions Firms $=$ Total

Fig. 2. Turkey external debt

(Source: https://www.cfr.org/blog/framing-turkeys-financialvulnerabilites-some-rhymes-asian-crisis-not-repeat)

emphasized that foreign currency borrowing of Turkey's companies will result with a struggling to repay the foreign currency loans. Today, Turkey's firms have around 287 billion Euro $(€)$ in foreign currency debt. It seems that a number of the firms that took out foreign currency loans don't really have natural hedges. The excessive increase and volatility in the rates will certainly increase the exchange rate expenses so that they may not be afforded by textile companies having debts of foreign exchange, so these companies will start to suffer losses soon as well. Figure 2 reveals Turkey external debt between the years of 1995 and 2018.

This study was thought to be useful with the contribution of analysing the exchange sensitivity of rates through 20 textile companies traded in Borsa Istanbul Corporate Governance Index within the years of 2013-2017. Foreign currency risk sensitivity analysis table was designed for this study. "Foreign currency risk sensitivity analysis table" (table 2) indicates profit before tax which occurs as a result of the foreign exchange gain/loss if Turkish lira ( against foreign currency by $10 \%$ and all other variables remains the same. It is obtained from table 2 that " 17 " of 20 textile firms have exchange risk which 


\begin{tabular}{|c|l|c|c|c|c|c|}
\hline No & \multicolumn{1}{|c|}{ Company name } & $\mathbf{2 0 1 3}$ & $\mathbf{2 0 1 4}$ & $\mathbf{2 0 1 5}$ & $\mathbf{2 0 1 6}$ & $\mathbf{2 0 1 7}$ \\
\hline 1 & AKIN TEKSTIL & $-238,471$ & $-20,447$ & 254,161 & 721,533 & 51,366 \\
\hline 2 & ARSAN TEKSTIL & $-1,163,696$ & $-2,449,072$ & $-2,217,828$ & $-2,237,298$ & $-1,598,777$ \\
\hline 3 & BILICI & 889,791 & $-781,647$ & $-1,390,943$ & $-1,848,672$ & $-1,178,372$ \\
\hline 4 & BIRKO AȘ & $-135,903$ & $-326,302$ & $-319,974$ & $-86,325$ & $-223,759$ \\
\hline 5 & BOSSA & 59,146 & $-1,293,427$ & $-1,397,957$ & $-3,404,728$ & $-3,905,811$ \\
\hline 6 & BIRLIK MENSUCAT & $-347,288$ & $-473,043$ & $-552,218$ & $-777,608$ & $-578,425$ \\
\hline 7 & DAGI & $-1,200,093$ & $-1,032,971$ & $-134,758$ & $-980,779$ & $-858,952$ \\
\hline 8 & DERIMOD & $-417,929$ & $-206,102$ & 103,067 & 83,710 & 117,017 \\
\hline 9 & DESA & $-1,836,234$ & $-1,887,335$ & $-1,900,063$ & $-2,034,719$ & $-5,054,311$ \\
\hline 10 & DIRITEKS & $-232,996$ & $-233,730$ & $-301,936$ & $-317,439$ & $-70,808$ \\
\hline 11 & HATEKS & $-166,193$ & 94,700 & 176,827 & $-641,398$ & $-612,990$ \\
\hline 12 & KARSU & $-1,519,588$ & $-2,596,286$ & $-2,667,606$ & $-3,223,688$ & $-2,459,341$ \\
\hline 13 & KORDSA & $2,342,900$ & 51,418 & $-676,875$ & $-5,389,380$ & $-158,451$ \\
\hline 14 & LUKS KADIFE & $-710,656$ & $-755,320$ & $-623,738$ & $-904,197$ & $-89,649$ \\
\hline 15 & MENDERES TEKSTIL & $-6,499,994$ & $-10,027,515$ & $-11,293,214$ & $-13,027,586$ & $-12,796,809$ \\
\hline 16 & RODRIGO TEKSTIL & 0 & $-55,960$ & $-696,443$ & $-55,839$ & $-42,947$ \\
\hline 17 & SOKTAȘ & $-3,633,528$ & $-4,271,780$ & $-5,036,315$ & $-5,931,261$ & $-4,360,719$ \\
\hline 18 & SONMEZ PAMUK & 247,801 & 179,496 & 240,403 & 864,134 & 279,010 \\
\hline 19 & YATAS CMB & $-561,056$ & $-381,013$ & $-983,149$ & $-779,396$ & $-380,656$ \\
\hline 20 & YUNSA & $-15,630$ & $-418,985$ & $-475,640$ & $-4,773,782$ & $-1,989,460$ \\
\hline & Total loss/gain (Euro) & $-15,139,617$ & $-26,885,321$ & $-29,894,198$ & $-44,744,716$ & $-35,912,843$ \\
\hline
\end{tabular}

the data in table were converted into Euro $(€)$ which is valid for the related year.

has been gradually increasing every year. According to their financial statements in 2017, if Turkish lira ( devaluates $10 \%$, total loss of textile firms will be reaching to $-35,912,843$ Euros. However, Turkish lira has already devaluated $\% 70$ for the last eight months. Hence, the total loss has been already reached to $219,068,342$ Euro $(€)$. Those mentioned firms in table are considerably important with the manner of big exporting capacities as well as for becoming the major importers in terms of raw material supply from the world countries. For instance, "Menderes" textile company which has $81 \%$ export capacity among the products and which is the major producer of "IKEA" has a very high foreign exchange gap. "Yünsa" which is the lead fabric supplier to many world textile brands has customers in more than 50 different countries. The company has many offices located in Germany and England. So the possible financial problems of those firms will not only affect the Turkish textile sector but all world textile market.

\section{RESULTS OF DISCUSSION}

46 Turkish textile companies are included in the list of biggest companies in ISO 500. 20 of 46 textile companies are traded in Borsa Istanbul. Within this study, the dates of those 20 firms were used between the years of 2013 and 2017.

Study Variables and Hypothesis: This study assumes that textile firms' performance is influenced by exchange rate and firms' characteristics. The dates for measuring the financial performance of the firms were obtained from the secondary sources (the annual reports of firms were published by Turkish Public Disclosure (KAP). Within the analyse, firm's performance is selected as the dependent variable whereas exchange rate, firm size and firm age is selected as the independent variables. Return on Assets (ROA) was used for measuring the firm performance. This popular ratio has been used widely for the past, present and future strategic decisions in early studies. ROA can be calculated by dividing net income after taxes on the Assets. Exchange rate, firm size and firm age are selected as the independent variables. In this study, exchange rate is selected as from Euro to Turkish lira (ఓ). From Dollar to Turkish lira (ఓ) was omitted in the model owing to the possible multi collinearity between the Euro and Dollar. Exchange rate exposure is known to be influencing the firms' performance regarding to early literature [22-25]. Firm size which may affect the firm performance in many aspects is selected as one of the other independent variable of the model. Early studies also support our hypothesis where size was correlated with market power. When considering firm ages; older firms are known to have more experience which determine their response for the exchange rate shocks and financial constraints [25-29].

Regression Model: ROA $=\alpha_{0}+\beta_{1}$ Log Exchange

Rate (LER) $+\beta_{2}$ Log Size (LS) $+\beta_{3}$ Age $+\varepsilon_{\mathrm{t}}$ $\mathrm{H}_{0}=$ there is no significant impact for exchange rate on firm's performance; $H_{0}{ }^{\prime}=$ there is no significant impact for size on firm's performance; $\mathrm{H}_{0}$ " = there is no significant impact for age on firm's performance. 


\begin{tabular}{|c|c|c|c|c|c|c|c|c|c|c|c|}
\hline \multicolumn{4}{|c|}{ Descriptive statitics } & \multicolumn{4}{c|}{ Pearson correlation results } \\
\hline & Minimum & Maximum & Mean & St. Deviation & Skewness & Kurtosis & & ROA & LER & LS & AGE \\
\hline ROA & -12 & 0.10 & 0.01 & 0.06 & -0.27 & -0.56 & ROA & 1 & $0.574^{* *}$ & $-0.187^{*}$ & 0.043 \\
\hline LER & 0.85 & 1.31 & 1.07 & 0.114 & -0.353 & -0.419 & LER & & 1 & 0.065 & $0.176^{*}$ \\
\hline LS & 4.31 & 15.43 & 8.56 & 0.821 & -0.543 & -0.231 & LS & & & 1 & 0.122 \\
\hline Age & 20 & 66 & 44.83 & 12.98 & -0.06 & 0.21 & Age & & & 1 \\
\hline
\end{tabular}

Table 4

\begin{tabular}{|c|c|c|}
\hline \multirow{2}{*}{ Dependent variable } & \multicolumn{2}{|c|}{ ROA } \\
\cline { 2 - 3 } & B. & sig. \\
\hline LER & -0.0274 & 0 \\
\hline LS & -0.0052 & -0.024 \\
\hline AGE & 0.768 & 0.549 \\
\hline Adj.R R $^{2}$ & \multicolumn{2}{|c|}{0.345} \\
\hline F Stat. & \multicolumn{2}{|c|}{10.43} \\
\hline Model Sig. & \multicolumn{2}{|c|}{0} \\
\hline D-W & \multicolumn{2}{|c|}{0.894} \\
\hline
\end{tabular}

Statistical Analysis: Before analyzing the hypothesis, descriptive analysis was conducted in order to explain the dates (table 3). According to table 3 , it is observed that ROA is $1 \%$ and the average firm age is approximately 45 years. Additionally, the average firm's size measured by the logarithm was found as 8.5. Table 4 indicates the Pearson correlation results where there is no multi collinearity relationship between the independent variables. Additionally, the primary results show that there is a significant relationship between ROA and LER and LS. These primary results will be re-tested by multiple regression analysis.

The specific assumptions must be provided for the evaluation of Multiple Regression. The first assumption related to multicollinearity, Pearson Correlation in table 3 indicated that there is no perfect relation between the independent variables. The second assumption is related to independent error. The Durbin Watson test (D-W) was used to conduct the test. According to table 4 , the results were found in the accepted range between 0 and 4 . The sample size is one of another multiple regression assumption. 10 observations were used within the study for each independent variable which is accepted according to according to Hair et al. [30]. Normality is the other assumption where skewness and kurtosis was used for testing it. The descriptive statistics table 3 supports that the results are within the accepted range, between -1 to 1 for Skewness and -3 to 3 for Kurtosis [31]. Table 4 indicates "Regression results of foreign exchange rate, size and age on firms' performance". According to regression results (table 4) it was observed that exchange rate volatility had a negative effect on the firm performance. The firm size had a negative effect while the firm age did not have any influence on firms' performance significantly.

\section{CONCLUSIONS}

Turkey has free-floating exchange rate markets which are not completely fixed by the government. $70 \%$ Approximate Devaluation of Turkish Liras in 2018 have noticeably influenced the Turkish textile sector. This study supports that some of the big Turkish textile companies carry the risk of profit loss or facing problems during the repayment of their debt due to high devaluation in Turkish Lira. According to table 2, 17 of 20 Turkish textile companies traded in Borsa İstanbul have foreign exchange gap. Also the regression analysis indicated that exchange rate movements led to decrement of financial performance of the firms with profit loss. It is advised for the mentioned firms to hedge the currency debt and credits in derivative markets as a precaution. Additionally, they should protect themselves from the possible foreign exchange risks by futures, forward, option and swap contracts. Another prominent result of the study is the profit loss as the firm size increased. This result indicates that the firms may suffer from some problems during the new strategic decisions, modernization and fast adaptation to the innovations. The firms should be able to move faster in the markets.

\section{BIBLIOGRAPHY}

[1] Atilgan, T., \& Kanat, S. The effects of the EU customs union with Turkey on the Turkish textile and clothing sector, In: Fibres \& Textiles in Eastern Europe, 2006, 4 (58), pp. 11-15.

[2] "World trade and GDP growth in 2016 and early 2017", In: World Trade Statistical Review (World Trade Organization), 2017, pp. 16-24.

[3] Ozturk, H. K. Energy usage and cost in textile industry: A case study for Turkey, In: Energy, 2005, 30(13), pp. 2424-2446.

[4] Atılgan, T. Effects of Textile and Clothing sector on the economy of Turkey, In: Fibres \& Textiles in Eastern Europe October / December 2006, Vol. 14, No. 4, p. 58

[5] International Cotton Advisory Committee (ICAC), "February Monthly Report", In: International Cotton Advisory Committee (ICAC), Washington, DC 20006 USA, 2016. 
[6] Karaalp, H. S., \& Yilmaz, N. D. Assessment of trends in the comparative advantage and competitiveness of the Turkish textile and clothing industry in the enlarged EU market, In: Fibres \& Textiles in Eastern Europe, 2012, No. 3 (92), pp. 8-12.

[7] Asalos, N., \& Lordanescu, M. The contribution of clusters to increase the competitiveness of the textile and clothing industry. Cluster analysis using location quotient method/Contributia clusterelor la cresterea competitivitatii industriei textile si de confectii. Analiza acestora prin metoda coeficientului de localizare, In: Industria Textila, 2015, 66(6), p. 370.

[8] TUIK (TURKISH STATISTICAL INSTITUTE), «http://www.tuik.gov.tr/PreTablo.do?alt_id=1001,» [Online]. [Date of access: 1406 2018].

[9] Nagahisarchoghaei, M., Nagahi, M., \& Soleimani, N. Impact of exchange rate movements on Indian firm performance, In: International Journal of Finance and Accounting, 2018, 7(4), pp. 108-121, DOI: 10.5923/j.ijfa.20180704.03.

[10] Aizenman, J., Edwards, S., \& Riera-Crichton, D. Adjustment patterns to commodity terms of trade shocks: the role of exchange rate and international reserves policies, 2012, In: Journal of International Money and Finance, 31, (8), pp. 1990-2016.

[11] Greenaway, D., Kneller, R., \& Zhang, X. The effect of exchange rates on firm exports: The role of imported intermediate inputs, In: The World Economy, 2010, 33(8), pp. 961-986.

[12] Jorion, P. The exchange-rate exposure of US multinationals, In: Journal of business, 1990, pp. 331-345.

[13] Amihud, Y., Levich, R. Exchange rates and the valuation of equity shares, In: Exchange Rates and Corporate Performance, Irwin, New York, 1994, pp. 49-59.

[14] Bartov, E. and Bodnar, G. M. Firm valuation, earnings expectations, and the exchange rate exposure effect, In: Journal of Finance, 1994, Vol. 49, pp. 1755-85.

[15] Bodnar, G. M., Gentry, W.M. Exchange rate exposure and industry characteristics: evidence from Canada, Japan, and the USA, In: Journal of International Money and Finance, 1993, February, pp. 29-45.

[16] He, J. and $\mathrm{Ng}$, L. The foreign exchange exposure of Japanese multinational corporations, In: Journal of Finance, Vol. 53, 1998, pp. 733-53.

[17] Doukas, J., Hall, P. H. and Lang, L. H. P. The pricing of currency risk in Japan, In: Journal of Banking and Finance, 1999, Vol. 23, pp. 1-20.

[18] Nydahl, S. Exchange rate exposure, foreign involvement and currency hedging of firms: some Swedish evidence, In: European Financial Management, 1999, Vol. 5, pp. 241-57.

[19] Khoo, A. Estimation of foreign exchange exposure: an application to mining companies in Australia, In: Journal of International Money and Finance, 1994, vol. 13, issue 3, pp. 342-363

[20] Chamberlain, S., Howe, J. and Popper, H. The exchange rate exposure of US and Japanese banking institutions, In: Journal of Banking and Finance, 1997, Vol. 21, pp. 871-92.

[21] Kiymaz, H. Estimation of foreign exchange exposure: an emerging market application, In: Journal of Multinational Financial Management, 2003, 13(1), pp. 71-84.

[22] Choi, J. J., \& Prasad, A. M. Exchange risk sensitivity and its determinants: a firm and industry analysis of US multinationals, In: Financial Management, 1995, pp. 77-88.

[23] McGuire, J. B., Sundgren, A., \& Schneeweis, T. Corporate social responsibility and firm financial performance, In: Academy of management Journal, 1988, 31(4), pp. 854-872.

[24] Kobeissi, N. (2004, March). Ownership structure and bank performance: evidence from the Middle East and North Africa. Economic Research Forum.

[25] Adler, M., \& Dumas, B. (1984). Exposure to currency risk: definition and measurement, In: Financial management, pp. $41-50$.

[26] Jorion, P. The exchange-rate exposure of US multinationals, In: Journal of business, 1990, pp. 331-345

[27] Shepherd, W. G. (1986) On the Core Concepts of Industrial Economics, In: H.W. De Jong and W. G. Shepherd, eds, Mainstreams in Industrial Organization. Dordrecht: Martinus Nijhoff Publishers.

[28] Leibenstein, H. (1976) Beyond Economic Man. Cambridge, MA: Harvard University Press.

[29] Nagahisarchoghaei, M., Nagahi, M., \& Soleimani, N. Impact of Exchange Rate Movements on Indian Firm Performance, In: International Journal of Finance and Accounting 2018, 7(4): pp.108-121, DOI: 10.5923/ j.ijfa.20180704.03.

[30] Hair.Jr., J. F., Black., W. C., Babin., B. J., Anderson., R. E., \& L.Tatham., R. (2006). Multivariant Data Analysis. In: New Jersey: Pearson International Edition.

[31] Jain, T.R. \& Aggarwal Dr. S.C. 2008. Quantitative methods for MBA. New Delhi: V.K. (India) Enterprises

\section{Authors:}

\section{YUSUF KAYA ${ }^{1}$, GIZEM GÜNAYDIN KARAKAN ${ }^{1,2}$, EMILIA VISILEANU ${ }^{3}$}

${ }^{1}$ Pamukkale University, Buldan Vocational School, Accounting Programme, 20400, Buldan, Denizli, Turkey 2Pamukkale University, Buldan Vocational School, Fashion\&Design Programme, 20400, Buldan, Denizli, Turkey

${ }^{3}$ The National Research and Development Institute for Textiles and Leather, 030508, Bucharest, Romania e-mail: ykaya@pau.edu.tr; ggunaydin@pau.edu.tr

Corresponding author:

YUSUF KAYA

e-mail: ykaya@pau.edu.tr 